Pacific Northwest National Laboratory

Operated by Battelle for the

U.S. Department of Energy
PNNL Administrative/Technical Procedures

\section{Surface Environmental Surveillance Procedures Manual, PNL-MA-580, Rev. 5}

Editors:

R. W. Hanf

T. M. Poston

L. E. Bisping

July 2007

Prepared for the U.S. Department of Energy under Contract DE-AC05-76RL01830 


\title{
DISCLAIMER
}

This report was prepared as an account of work sponsored by an agency of the United States Government. Neither the United States Government nor any agency thereof, nor Battelle Memorial Institute, nor any of their employees, makes any warranty, express or implied, or assumes any legal liability or responsibility for the accuracy, completeness, or usefulness of any information, apparatus, product, or process disclosed, or represents that its use would not infringe privately owned rights. Reference herein to any specific commercial product, process, or service by trade name, trademark, manufacturer, or otherwise does not necessarily constitute or imply its endorsement, recommendation, or favoring by the United States Government or any agency thereof, or Battelle Memorial Institute. The views and opinions of authors expressed herein do not necessarily state or reflect those of the United States Government or any agency thereof.

\author{
PACIFIC NORTHWEST NATIONAL LABORATORY \\ operated by \\ BATTELLE \\ for the \\ UNITED STATES DEPARTMENT OF ENERGY \\ under Contract DE-AC05-76RL01830
}

Printed in the United States of America
Available to DOE and DOE contractors from the Office of Scientific and Technical Information,
P.O. Box 62, Oak Ridge, TN 37831-0062;
ph: (865) 576-8401
fax: (865) 576-5728
email: reports@adonis.osti.gov

\author{
Available to the public from the National Technical Information Service, \\ U.S. Department of Commerce, 5285 Port Royal Rd., Springfield, VA 22161 \\ ph: (800) 553-6847 \\ fax: (703) 605-6900 \\ email: orders@ntis.fedworld.gov \\ online ordering: http://www.ntis.gov/ordering.htm
}




\section{PNNL Administrative/Technical Procedures}

\section{Surface Environmental Surveillance \\ Procedures Manual, PNL-MA-580, Rev. 5}

\section{Editors:}

R. W. Hanf

T. M. Poston

L. E. Bisping

July 2007

Prepared for

the U.S. Department of Energy

under Contract DE-AC05-76RL01830

Pacific Northwest National Laboratory

Richland, Washington 99352 
Environmental Characterization and Risk Assessment Group

\section{Surface Environmental Surveillance Procedures Manual}

In case of termination or transfer, retum this manual to Document Control, K3-70.

T. M. Poston, Manager

Surface Environmental Surveillance Project

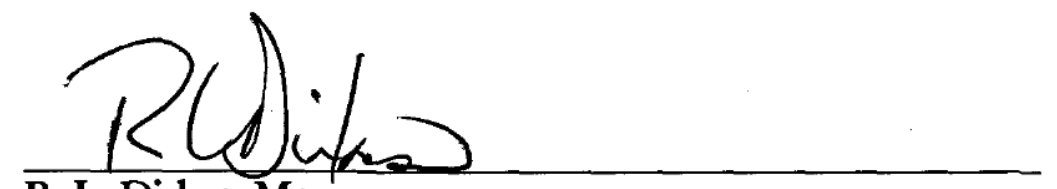

R. L. Dirkes, Manager

Public Safety and Resource Protection Program

Pacific Northwest National Laboratory

Richland, Washington 


\section{Table of Contents}

1.0 Introduction

Issue Date

2.0 Responsibilities

01/07

3.0 Air Sampling Procedures

02/07

3.1 Air-Particulate Samples.

03/07

3.2 Atmospheric Tritium Samples

03/07

3.3 Iodine-129 Samples.

03/07

05/07

4.0 Surface-Water and Sediment Sampling

03/07

4.1 Irrigation Water, Pond Water, and Pond Sediment.

03/07

4.2 Columbia River Composite Water Samples

03/07

4.3 Columbia River Continuous Water Samples

03/07

4.4 Transect and Near-Shore Water Samples.

03/07

4.5 Riverbank Spring Water and Sediment

03/07

4.6 Conductivity Measurement

03/07

4.7 pH Measurement

03/07

4.8 Filtered Water Samples

03/07

4.9 Columbia River Sediment

03/07

5.0 Soil and Vegetation Sampling

03/07

5.1 Surface Soil Samples.

03/07

5.2 Terrestrial Vegetation Samples

03/07

6.0 Food and Farm Products Sampling Procedures

02/07

6.1 Milk Samples.

$01 / 07$

6.2 Crop Samples

01/07

6.3 Wine Samples.

01/07

7.0 Wildlife Sampling

05/07

7.1 Fish

7.2 Waterfowl.

05/07

7.3 Rabbits.

05/07

7.4 Game Birds.

7.5 Deer and Elk 
$\underline{\text { Issue Date }}$

8.0 Miscellaneous Procedures .............................................................................

8.1 Chain-of-Custody Forms ......................................................................... 02/07

8.2 Radiation Work Permits ............................................................................

8.3 Radiological Surveys of Samples................................................................ 05/07

8.4 Using Firearms …….............................................................................

8.5 Determining Geographic Positions ............................................................. 05/07

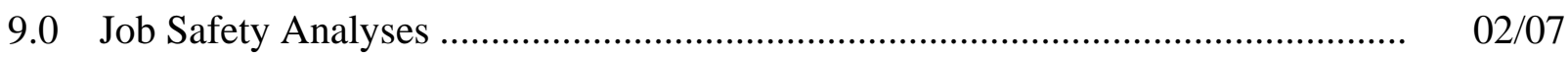

9.1 Operation of Boats ................................................................................... 02/07

9.2 Environmental Sampling........................................................................

9.3 Using Firearms …………………........................................................

9.4 Operation of Electrofisher ....................................................................... 05/07 


\subsection{INTRODUCTION}

\begin{tabular}{|c|c|}
\hline $\begin{array}{l}\text { ENVIRONMENTAL } \\
\text { SURVEILLANCE }\end{array}$ & $\begin{array}{l}\text { Hanford Site environmental surveillance is conducted by the Pacific } \\
\text { Northwest National Laboratory (PNNL) for the U.S. Department of } \\
\text { Energy (DOE) under the Surface Environmental Surveillance Project } \\
\text { (SESP). The basic requirements for site surveillance are set forth in DOE } \\
\text { Order 450.1, Environmental Protection Program. Guidance for the SESP } \\
\text { is provided in DOE Order 5400.5, Radiation Protection of the Public and } \\
\text { Environment. Guidelines for environmental surveillance activities are } \\
\text { provided in DOE/EH-0173T, Environmental Regulatory Guide for } \\
\text { Radiological Effluent Monitoring and Environmental Surveillance. An } \\
\text { environmental monitoring plan for the Hanford Site is outlined in } \\
\text { DOE/RL-91-50 Environmental Monitoring Plan, United States } \\
\text { Department of Energy, Richland Operations Office. } \\
\text { Environmental surveillance data are used in assessing the impact of current } \\
\text { and past site operations on human health and the environment, } \\
\text { demonstrating compliance with applicable local, state, and federal } \\
\text { environmental regulations, and verifying the adequacy of contaminant and } \\
\text { effluent controls. } \\
\text { SESP sampling schedules are reviewed, revised, and published each } \\
\text { calendar year in the Hanford Site environmental surveillance master } \\
\text { sampling schedule. Environmental samples are collected by SESP } \\
\text { personnel in accordance with the approved sample collection procedures } \\
\text { documented in this manual. Personnel training requirements are } \\
\text { documented in SESP-TP-01 Surface Environmental Surveillance Project } \\
\text { Training Program. }\end{array}$ \\
\hline $\begin{array}{l}\text { MANUAL } \\
\text { SCOPE/USE }\end{array}$ & $\begin{array}{l}\text { This manual contains the procedures that are used for the collection of } \\
\text { SESP environmental samples and field measurements on and around the } \\
\text { Hanford Site. Specific responsibilities for personnel involved in SESP } \\
\text { environmental surveillance activities are defined in Section } 2.0 \text { of this } \\
\text { manual. }\end{array}$ \\
\hline
\end{tabular}

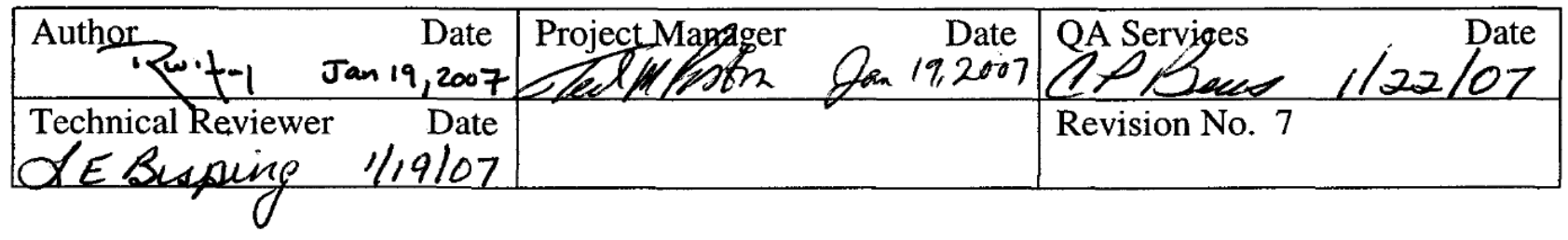




\begin{tabular}{|c|c|}
\hline & $\begin{array}{l}\text { This manual is intended for use by SESP personnel. Project specific } \\
\text { training is required for all individuals collecting SESP samples or field } \\
\text { measurements. The training will assure that the procedures in this manual } \\
\text { are understood and properly applied. Training also assures that } \\
\text { representative samples and measurements are collected in a safe and } \\
\text { consistent manner and that analytical results are comparable between } \\
\text { locations and over time. }\end{array}$ \\
\hline USE CATEGORY & $\begin{array}{l}\text { The procedures in this manual fall under the Standards-Based Management } \\
\text { System (SBMS) "Reference Use" category. Procedures will be available } \\
\text { to the individuals performing the work but the procedures can be } \\
\text { performed from memory. }\end{array}$ \\
\hline $\begin{array}{l}\text { MANUAL } \\
\text { REVISIONS AND } \\
\text { UPDATES }\end{array}$ & $\begin{array}{l}\text { The procedures described in this manual are reviewed annually by SESP } \\
\text { personnel to assure that major revisions to existing procedures and new } \\
\text { procedures are incorporated promptly. Small corrections or revisions that } \\
\text { do not warrant complete manual updates may be issued to manual holders } \\
\text { in the form of interim procedures. Interim procedures may be used for } \\
\text { documenting changes to existing procedures. Interim procedures will be } \\
\text { issued on a temporary basis (up to } 1 \text { year) and will be valid until the } \\
\text { appropriate section is updated. After initial issuance and training, it is the } \\
\text { responsibility of each manual holder to retain a copy of the interim } \\
\text { procedure and be familiar with its contents. } \\
\text { To assure that the procedures in this manual are accurate, complete, in the } \\
\text { correct format, and usable, the following requirements must be met before } \\
\text { a new, revised, or interim procedure is issued: } \\
\text { - All new, interim, or revised procedures must be reviewed by the } \\
\text { project manager, the project quality engineer, and a technical } \\
\text { reviewer prior to issuance. Issuance approval by the author and the } \\
\text { reviewers must be documented on the first page of the procedures } \\
\text { with dated signatures. } \\
\text { Appropriate training must be provided to all personnel involved in } \\
\text { SESP sample collection activities when new, revised, or interim } \\
\text { procedures are issued. Such training shall be documented in the } \\
\text { SESP personnel training files. }\end{array}$ \\
\hline
\end{tabular}




\begin{tabular}{|c|c|}
\hline $\begin{array}{l}\text { SUPPLEMENTAL } \\
\text { INFORMATION }\end{array}$ & $\begin{array}{l}\text { In addition to the procedures in this manual, supplemental information, } \\
\text { such as procedure flow charts, condensed procedures, etc, may be } \\
\text { produced by various individuals within the SESP, approved by the } \\
\text { appropriate media task leader, and distributed to SESP personnel. } \\
\text { Supplemental information will only be used to clarify or support existing } \\
\text { approved procedures. To the extent possible, supplemental information } \\
\text { will be prepared and reviewed to assure consistency with the approved } \\
\text { procedures. If a discrepancy between the supplemental information and } \\
\text { the approved procedures is observed, the appropriate media task leader or } \\
\text { the sample collection task leader must be contacted for clarification. If the } \\
\text { appropriate personnel are unavailable for assistance, the procedures in this } \\
\text { manual (PNL-MA-580) will be followed until the discrepancy can be } \\
\text { resolved. All such discrepancies should be brought to the attention of the } \\
\text { sample collection task leader or the appropriate media task leader in a } \\
\text { timely fashion. }\end{array}$ \\
\hline $\begin{array}{l}\text { MANUAL } \\
\text { CONTROL }\end{array}$ & $\begin{array}{l}\text { Distribution of this manual is controlled through PNNL's Records } \\
\text { Department. Project management approval of manual content is } \\
\text { documented through sign-offs on the title page of each manual section. } \\
\text { Each manual is uniquely numbered and assigned to a specific individual. } \\
\text { All updates will be mailed to the individual manual holders along with a } \\
\text { receipt acknowledgment form that must be signed, dated, and returned to } \\
\text { document control within a specified period of time. It is the responsibility } \\
\text { of the assigned manual holders to return their acknowledgment forms and } \\
\text { to incorporate all changes in a timely manner, thereby keeping their } \\
\text { manual current. Periodic audits may be conducted to assure that manuals } \\
\text { are being properly maintained. Manuals that are no longer needed should } \\
\text { be returned to the sample collection task leader or the Records Department } \\
\text { for reassignment. }\end{array}$ \\
\hline
\end{tabular}




\subsection{RESPONSIBILITIES}

\begin{tabular}{|c|c|}
\hline INTRODUCTION & $\begin{array}{l}\text { This section provides a summary of some of the responsibilities of SESP } \\
\text { personnel who are accountable for the collection and transport of } \\
\text { environmental samples, the issuance and proper completion of sample chain- } \\
\text { of-custody paperwork, the acquisition and storage of analytical data, and the } \\
\text { maintenance of project manuals. Included are some of the specific } \\
\text { responsibilities associated with each job category, and the general } \\
\text { responsibilities of all personnel participating either actively or passively in } \\
\text { SESP environmental sampling or measurement activities. }\end{array}$ \\
\hline $\begin{array}{l}\text { PROJECT } \\
\text { PERSONNEL }\end{array}$ & $\begin{array}{l}\text { All project personnel are responsible for maintaining and updating the project } \\
\text { manuals assigned to them when changes or updates to the manuals are issued. } \\
\text { Each manual is uniquely numbered and assigned to a specific individual. All } \\
\text { updates will be mailed to the individual manual holders along with a receipt } \\
\text { acknowledgement form that must be signed, dated, and returned to Document } \\
\text { Control within a specified period of time. It is the responsibility of the } \\
\text { assigned manual holders to incorporate all changes and return the receipt } \\
\text { acknowledgment form in a timely manner. Periodic audits may be conducted } \\
\text { to assure that manuals are being properly maintained. Manuals that are no } \\
\text { longer needed should be returned to the sample collection task leader or } \\
\text { Document Control for reassignment. } \\
\text { All project personnel must also: } \\
\text { - Perform their work in a safe and proper manner and notify the } \\
\text { appropriate task leader of any unsafe conditions or requirements. } \\
\text { Project staff will be responsible for reviewing and understanding the } \\
\text { project Job Safety Analyses (JSAs) and all applicable PNNL SBMS } \\
\text { categories prior to conducting any sampling activities. } \\
\text { - } \\
\text { Notify the PNNL Operations Center (375-2154 or 375-2400) of any out- } \\
\text { of-the-ordinary incidents or occurrences. These can include safety } \\
\text { issues (i.e. electrical shocks), vandalism, accidents and injuries, permit } \\
\text { violations, etc. } \\
\text { Remember that all activities associated with sample and measurement } \\
\text { collections must be performed properly and according to procedures or } \\
\text { instructions to ensure that accurate and defensible data are obtained. }\end{array}$ \\
\hline
\end{tabular}

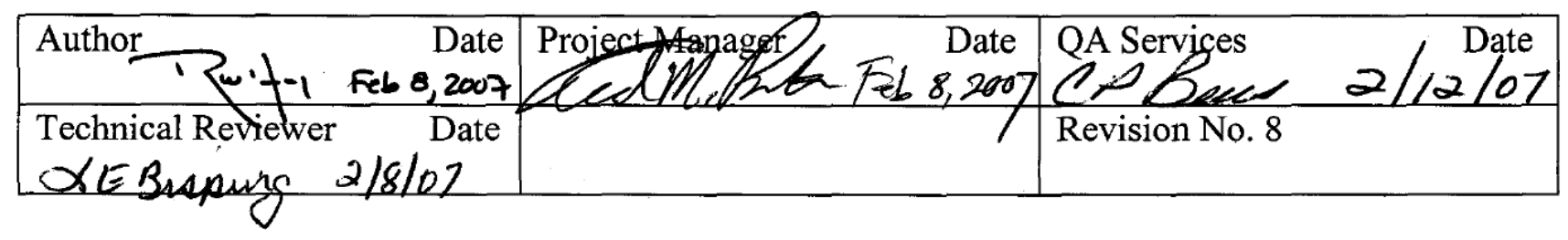




\begin{tabular}{|c|c|}
\hline & $\begin{array}{l}\text { - Assure that sampling equipment is properly stored and that storage areas } \\
\text { are kept neat and orderly. }\end{array}$ \\
\hline $\begin{array}{l}\text { PROJECT } \\
\text { MANAGER }\end{array}$ & $\begin{array}{l}\text { The project manager is responsible for the technical quality and completeness } \\
\text { of all procedures associated with the project. The project manager must } \\
\text { assure that: } \\
\text { - An approved procedure is in place for each routine SESP field sampling } \\
\text { or measurement activity. } \\
\text { - Project manuals are reviewed and updated on an annual basis. } \\
\text { - Personnel are properly trained prior to engaging in SESP field sampling } \\
\text { or measurement activities. } \\
\text { - All applicable Job Safety Analysis (JSA) sheets are reviewed annually } \\
\text { and revisions are approved by a PNNL Worker Safety and Health } \\
\text { representative. }\end{array}$ \\
\hline $\begin{array}{l}\text { MEDIA TASK } \\
\text { LEADERS }\end{array}$ & $\begin{array}{l}\text { Media task leaders are responsible for planning and scheduling the collection } \\
\text { of environmental samples and measurements; evaluating and selecting } \\
\text { sampling and measurement equipment; determining sampling and } \\
\text { measurement locations and frequencies; preparing the procedures contained } \\
\text { in this manual; and training personnel to collect SESP samples or obtain } \\
\text { measurements according to the procedures in this manual or to approved } \\
\text { interim or supplemental procedures. } \\
\text { Additional responsibilities include: } \\
\text { - Assuring that an approved procedure is in place for each routine SESP } \\
\text { field sampling or measurement activity. } \\
\text { - Assuring that approved procedures are technically sound, accurate, and } \\
\text { complete, and are updated to reflect operational changes. } \\
\text { - Assuring that the project manuals are reviewed and updated on an } \\
\text { annual basis and that updates and revisions are done in a timely manner. } \\
\text { - Assuring that personnel are properly trained prior to engaging in SESP } \\
\text { sampling activities. } \\
\text { Cleaning up and securing (locking) work vehicles, work areas, and } \\
\text { sample storage locations. } \\
\text { poordinating work requiring the use of environmental monitoring }\end{array}$ \\
\hline
\end{tabular}


- Preparing all supplemental guidance for collecting environmental samples and verifying that it is correct, and consistent with the direction provided in this manual.

- Assuring that sampling equipment is functioning as expected.

- Modifying sampling strategies to reflect the current operational needs of the site or the client.

- Assuring that sample containers and sampling equipment are prepared for field use prior to field collection activities.

- Assuring that samples scheduled for analyses at offsite laboratories are packaged and shipped within critical time lines.

SAMPLE

COLLECTION TASK LEADER
The sample collection task leader is responsible for coordinating the sample collection field crew, scheduling daily work assignments for the environmental RCT and other sample collection personnel, and for arranging the timely collection of SESP routine and special samples and measurements.

The sample collection task leader must assure that:

- Sample collections and measurements are conducted in accordance with the procedures outlined in this manual or in accordance with approved interim or supplemental procedures.

- Sample collections and measurements are conducted in accordance with the sampling schedule outlined in the environmental surveillance master sampling schedule.

- All necessary sampling and measurement equipment is properly maintained and calibrated and that all maintenance and calibration records are properly filed.

- Routine sampling equipment is available and in working condition prior to the start of scheduled sampling activities.

- Broken or outdated equipment is repaired or replaced in a timely manner.

- Stations are kept clean and orderly.

- An adequate supply of materials and equipment necessary for collecting SESP samples and measurements is maintained. 


\begin{tabular}{|c|c|}
\hline & $\begin{array}{l}\text { - Job-specific training is provided to sample collection personnel prior to } \\
\text { their deployment in the field. } \\
\text { - Appropriate safety training is provided to sample collection personnel } \\
\text { and JSA sheets are available on demand for project personnel to review. } \\
\text { - Chain-of-custody paperwork (trip sheets) is properly and accurately } \\
\text { filled out by sample collection personnel before samples are delivered to } \\
\text { the analytical laboratory. }\end{array}$ \\
\hline $\begin{array}{l}\text { SAMPLE } \\
\text { COLLECTION } \\
\text { PERSONNEL }\end{array}$ & $\begin{array}{l}\text { Sample collection personnel collect (or assist with the collection of) } \\
\text { environmental samples and perform field measurements in accordance with } \\
\text { the procedures outlined in this manual, approved interim or supplemental } \\
\text { procedures, appropriate radiation work procedures, or as directed by the } \\
\text { project manager, sample collection task leader, or media task leader. } \\
\text { Sample collection personnel are also responsible for: } \\
\text { - } \quad \text { Attending SESP training sessions as required. } \\
\text { - Knowing the sampling procedures associated with the work they are } \\
\text { assigned or are conducting. If necessary, pertinent procedures will be } \\
\text { reviewed prior to doing the work. } \\
\text { - Maintaining or replacing sampling equipment as appropriate or when } \\
\text { instructed to do so by the sample collection task leader. } \\
\text { - Assuring the sampling equipment is prepared for use in the field, and the } \\
\text { equipment is properly cleaned and stored following sampling. } \\
\text { - Cleaning up and securing (locking) work vehicles, work areas, and } \\
\text { sample storage locations. } \\
\text { Notifying the sample collection task leader or appropriate media task } \\
\text { leader if: 1) samples are not collected or work is not performed as } \\
\text { scheduled, 2) unusual conditions are observed while sampling that } \\
\text { might impact sampling or sampling results, 3) sampling equipment or } \\
\text { procedures are unsafe, and 4) actual sampling procedures differ from the } \\
\text { procedures outlined in this manual. } \\
\text { task leader when inventories are getting low and replacement equipment } \\
\text { and materials are needed. }\end{array}$ \\
\hline
\end{tabular}




\begin{tabular}{|c|c|}
\hline & $\begin{array}{l}\text { - Keeping track of radiation survey instruments obtained from the loan } \\
\text { pool for SESP work. } \\
\text { - Handling, storing, or delivering samples in accordance with the } \\
\text { procedures described herein. } \\
\text { - Completing chain-of-custody paperwork accurately and according to the } \\
\text { procedures outlined in this manual. } \\
\text { - Working safely and alerting the sample collection task leader, one of the } \\
\text { media task leaders, or the group leader of any job-related safety } \\
\text { concerns. } \\
\text { Providing suggestions for improvements in procedures, in equipment, or } \\
\text { in the operation of the program itself. }\end{array}$ \\
\hline $\begin{array}{l}\text { DATA } \\
\text { MANAGEMENT } \\
\text { TASK LEADER }\end{array}$ & $\begin{array}{l}\text { The data management task leader is responsible for preparing SESP sample } \\
\text { labels, chain-of-custody forms, and trip-log reports for all routine and non- } \\
\text { routine samples and measurements collected by SESP sample collection } \\
\text { personnel. } \\
\text { The data management task leader is also responsible for: } \\
\text { - Assisting the media task leaders in planning and implementing all } \\
\text { routine and non-routine SESP sample collections. } \\
\text { - Preparing a calendar year SESP master sampling schedule. } \\
\text { - Providing training to SESP personnel on chain-of-custody procedures. } \\
\text { Interacting with the analytical laboratories on matters dealing with SESP } \\
\text { samples, sample labeling, sampling substrates, data deliveries, and } \\
\text { analytical and data issues. } \\
\text { - Managing all SESP analytical data and data storage and retrieval } \\
\text { software. } \\
\text { - Managing all SESP sample collection records. } \\
\text { Reviewing SESP chain-or-custody forms for accuracy and completeness } \\
\text { before samples are submitted to an analytical laboratory. } \\
\text { media task leaders when analytical data are suspect. }\end{array}$ \\
\hline
\end{tabular}




\begin{tabular}{|c|c|}
\hline & $\begin{array}{l}\text { - Tracking all samples that are scheduled for collection and providing } \\
\text { periodic collection status reports to the media task leaders. } \\
\text { - Acting as a backup for the sample collection task leader. }\end{array}$ \\
\hline $\begin{array}{l}\text { SAMPLE } \\
\text { ANALYSIS TASK } \\
\text { LEADER }\end{array}$ & $\begin{array}{l}\text { The sample analysis task leader is responsible for: } \\
\text { - Administering the SESP analytical contracts. } \\
\text { - Tracking performance of the analytical laboratories. } \\
\text { - } \quad \text { Scheduling inspections and audits of the analytical laboratories. } \\
\text { personnel. }\end{array}$ \\
\hline $\begin{array}{l}\text { QUALITY } \\
\text { ASSURANCE/ } \\
\text { QUALITY } \\
\text { CONTROL TASK } \\
\text { LEADER }\end{array}$ & $\begin{array}{l}\text { The SESP quality assurance (QA)/quality control (QC) task leader is } \\
\text { responsible for; } \\
\text { - Auditing the internal quality control programs at the analytical } \\
\text { laboratories. } \\
\text { - Reviewing analytical data resulting from participation in interlaboratory } \\
\text { crosschecks, and the analysis of replicate samples, blind standard } \\
\text { samples and blanks, and split or duplicate samples. } \\
\text { - Working with the analytical laboratories to resolve data quality issues. }\end{array}$ \\
\hline
\end{tabular}




\subsection{AIR SAMPLING PROCEDURES}

Air is a primary pathway for radionuclides from Hanford to reach the public. Routine air sampling provides a means to assess the environmental impact of radionuclide releases from site operations, demonstrate compliance with applicable state and federal concentration guidelines, check the effectiveness of waste containment and effluent control systems, and evaluate the potential doses to offsite populations from airborne radionuclides.

Air samples are collected continuously at numerous locations on the site, at the site perimeter, and in both nearby and distant communities. The types of samples routinely collected include:

- Air-particulate samples (Section 3.1).

- Atmospheric tritium samples (as HTO) (Section 3.2).

- Iodine-129 samples (Section 3.3).

Figure 3.0.1 illustrates the air-sampling systems currently in use.

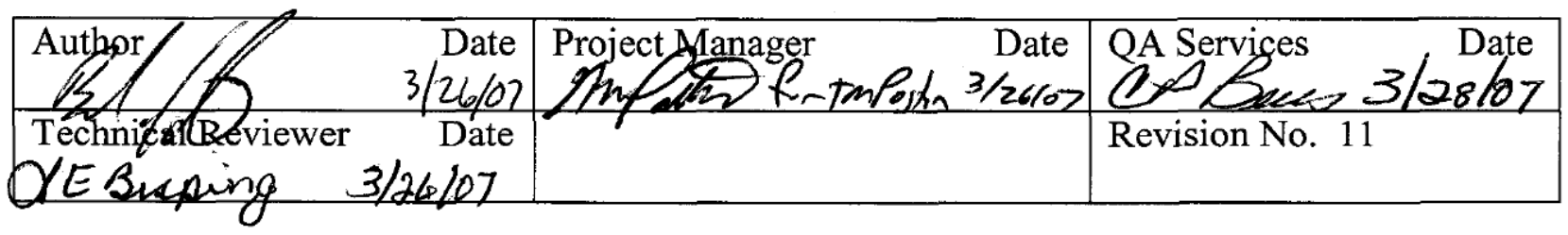



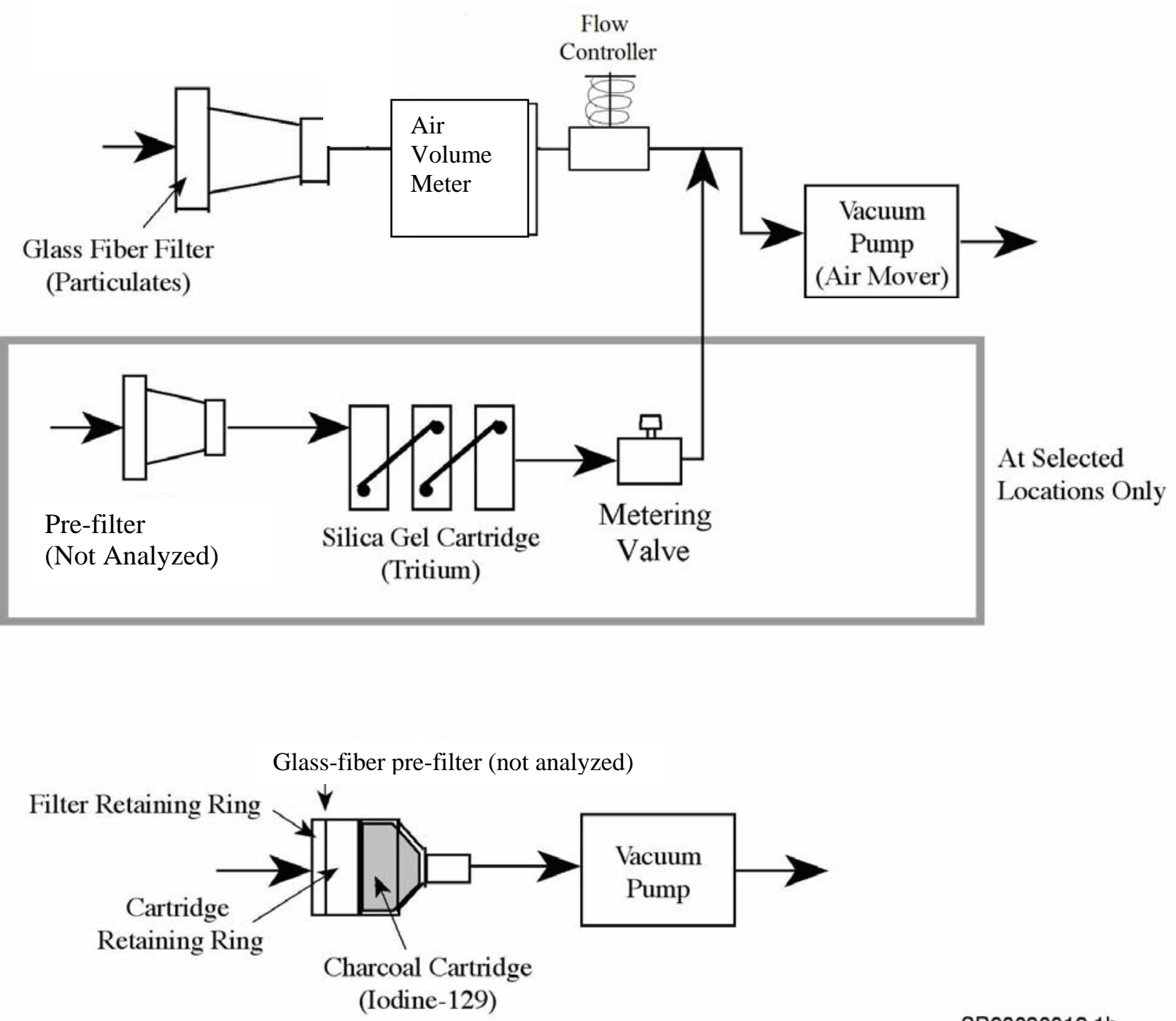

SP98030012.1b

Figure 3.0.1. Air Sampling Systems for Radioactive Particulates, Tritium, and Iodine-129 


\subsection{AIR-PARTICULATE SAMPLES}

INTRODUCTION

EQUIPMENT AND SUPPLIES
BEFORE SAMPLE COLLECTION
This procedure governs the collection of air-particulate samples. Air particulates are collected on glass-fiber filters and the filters are analyzed for a variety of radionuclides.

The following equipment and supplies may be needed when collecting air-particulate samples:

- Clean filter-head assemblies (in plastic jars with lids) with filters already installed.

- An air flow calibrator.

- $\quad$ Extra 2-inch diameter glass-fiber filters.

- $\quad$ Rain guards (hoods) for filter holders.

- $\quad$ Plastic tubing (3/8- and 1/2-in. ID) for tubing repairs.

- Hose clamps (large and small, plastic and metal).

- Spare vacuum pumps (a least two), flow controllers, air volume meters.

- $\quad$ Assorted tools for minor repairs.

- $\quad$ Sample labels and chain-of-custody forms.

- Lubricant (for hutch locks).

- Insecticide for bees and wasps in air hutches.

Pick up a supply of unexposed filter head assemblies from the analytical laboratory. As a general rule, pick up as many fresh filter head assemblies as the number of samples submitted. This will maintain an adequate supply of fresh, unexposed filter heads in the field sampling truck for the next day's sampling efforts.

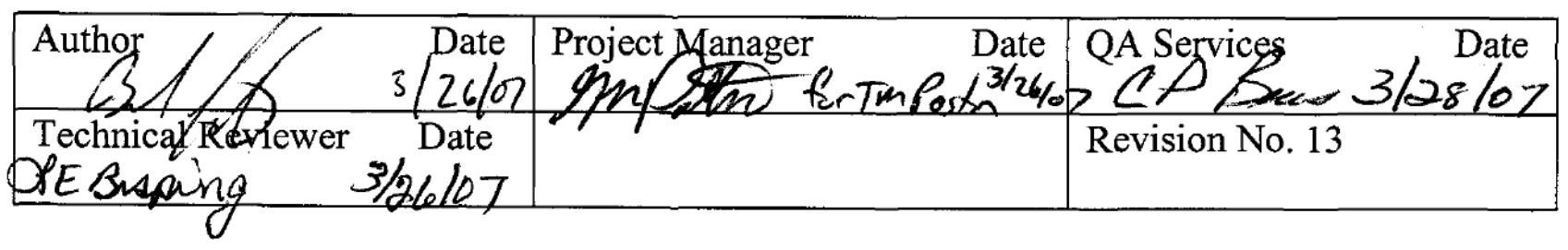


During warm months, bees and wasps frequently build nests in the sampling hutches. Look for evidence of bees and wasps before opening a hutch.

- In the comment section of the chain-of-custody form, note any conditions near the sample site that might affect sample results, such as new construction and farming activities.

- In the comment section of the chain-of-custody form, note any problems with the sampling system before disturbing the system in any way.

SAMPLE COLLECTION
1. Open the hutch. If the pump is running, follow these procedures. If the pump is not running, consult the TROUBLESHOOTING section of these procedures.

2. Check the digital (mechanical) display on the air-volume meter to see if the black and white 'pinwheel' is spinning. If the pinwheel is spinning, continue with this procedure. If the pinwheel is not spinning, skip to the TROUBLESHOOTING section, below.

3. If a tritium sampler (silica gel column) is present, skip to Section 3.2 before continuing with this procedure.

4. Record the sampling date and time on the chain-of-custody form and the sampling date on the sample label.

5. Record the first four digits of the volume from the air-volume meter digital readout (cubic meters) in the End Vol/Flow field on the chain-of-custody form.

NOTE: Occasionally, a sample volume may be below what is normally expected (normal is around 856 cubic meters for a 2-week sampling period). Compute the total air volume by subtracting the start volume from the end volume. If the air volume appears abnormally low, consult the TROUBLESHOOTING section below, or the text discussing UNSUCCESSFUL SAMPLING ATTEMPTS in Section 8.1.

6. Remove the particulate filter-head assembly and examine the exposed filter.

7. Record in the comment section on the chain-of-custody form any observed anomalies such as damage to the filter, excessive moisture, or frost/snow collected on the filter face. 


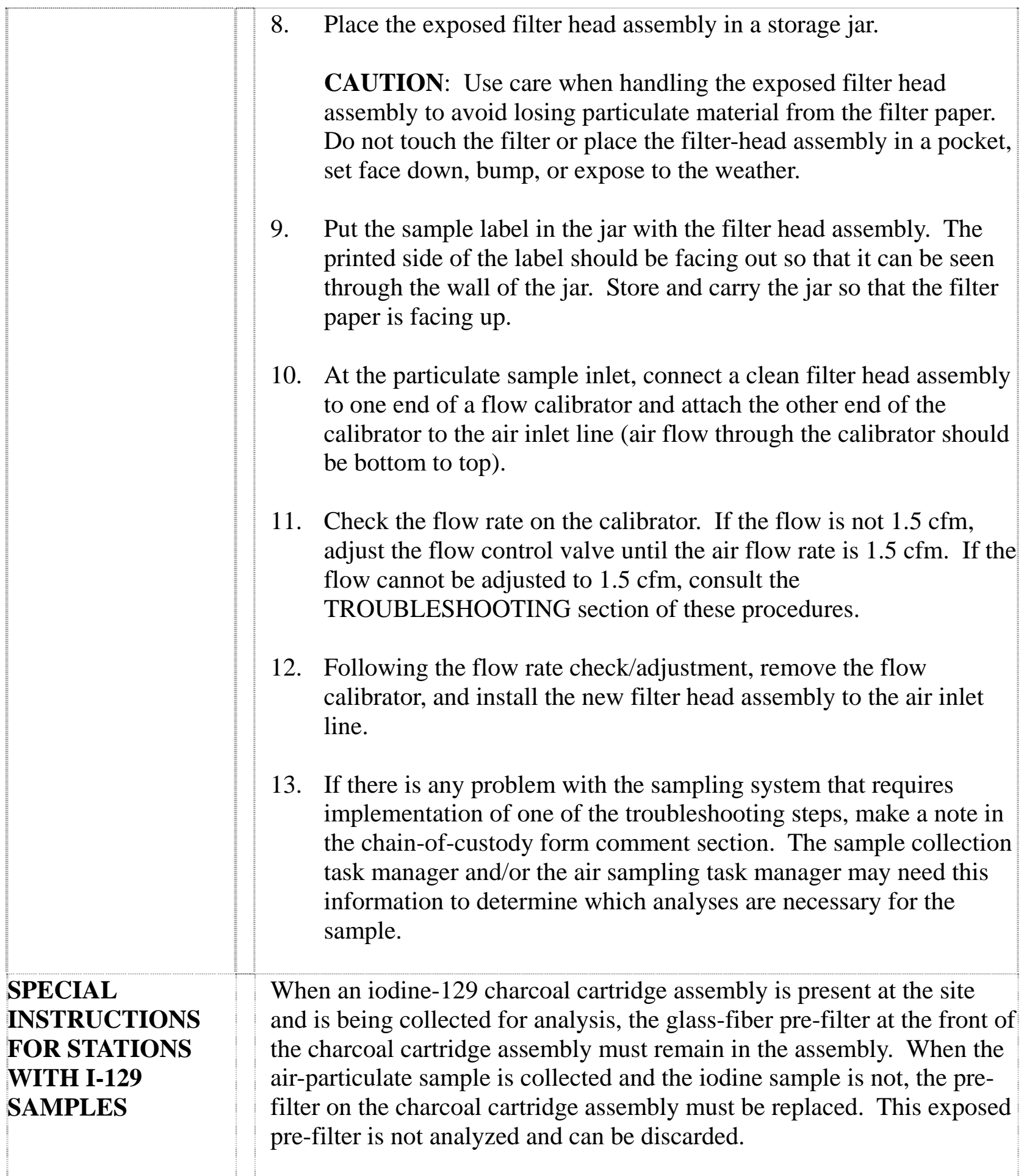


TROUBLESHOOTING

\section{If the pump is not running:}

- Check for power in the hutch by plugging in another pump. If the pump works, replace the old pump with a new one.

- If the other pump is plugged in but does not work, check to see if the ground fault circuit interrupter (GFCI) and circuit breaker (if there is one) are okay. If not, can they be reset? If they can be reset, continue with sample collection. If not, unplug the hutch fan and the old pump. Electrical shorts in the hutch fan and pump can cause the breaker and GFCI to trip. If the breaker and GFCI still will not reset, plug the hutch fan and the old pump back in, follow steps 5 through 9 and 13 in the SAMPLE COLLECTION section above, and report the power problem to the sample collection task leader.

- If a new pump is installed in place of the old one, write the installation date on the tag attached to the new pump and make sure the pump number and sampling location are also written on the tag.

- Write the removal date on the tag on the old pump tag and an explanation of why the pump was removed from service. Verify that the pump number and sampling location are also written on the tag.

- If the new pump is running, return to step 3 in the SAMPLE COLLECTION section above and continue with collecting the sample.

- If the new pump will not run (there is no power at the station), return to step 3 in the SAMPLE COLLECTION section above and continue with the collection of the exposed sample. Following sample collection, install a new filter head assembly (and tritium column, if needed) so that the station will resume sampling when power to the station is restored. The air flows through the particulate filter and tritium sampler will have to be checked and/or adjusted at a later time.

If the pump is running but the air-volume meter pinwheel is not turning:

- Use an air flow calibrator at the sample inlet to determine if there is air flow through the sampling system. 


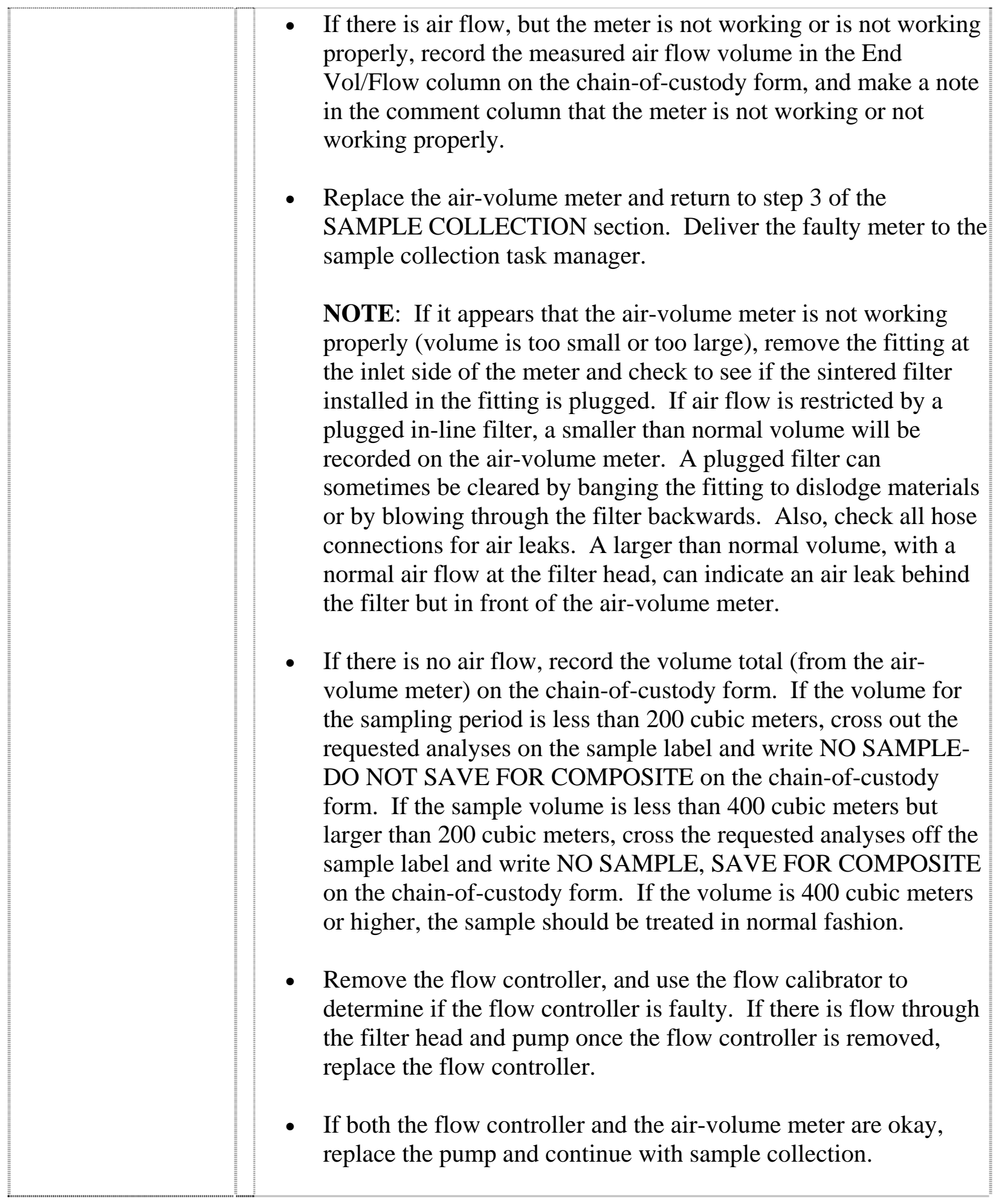




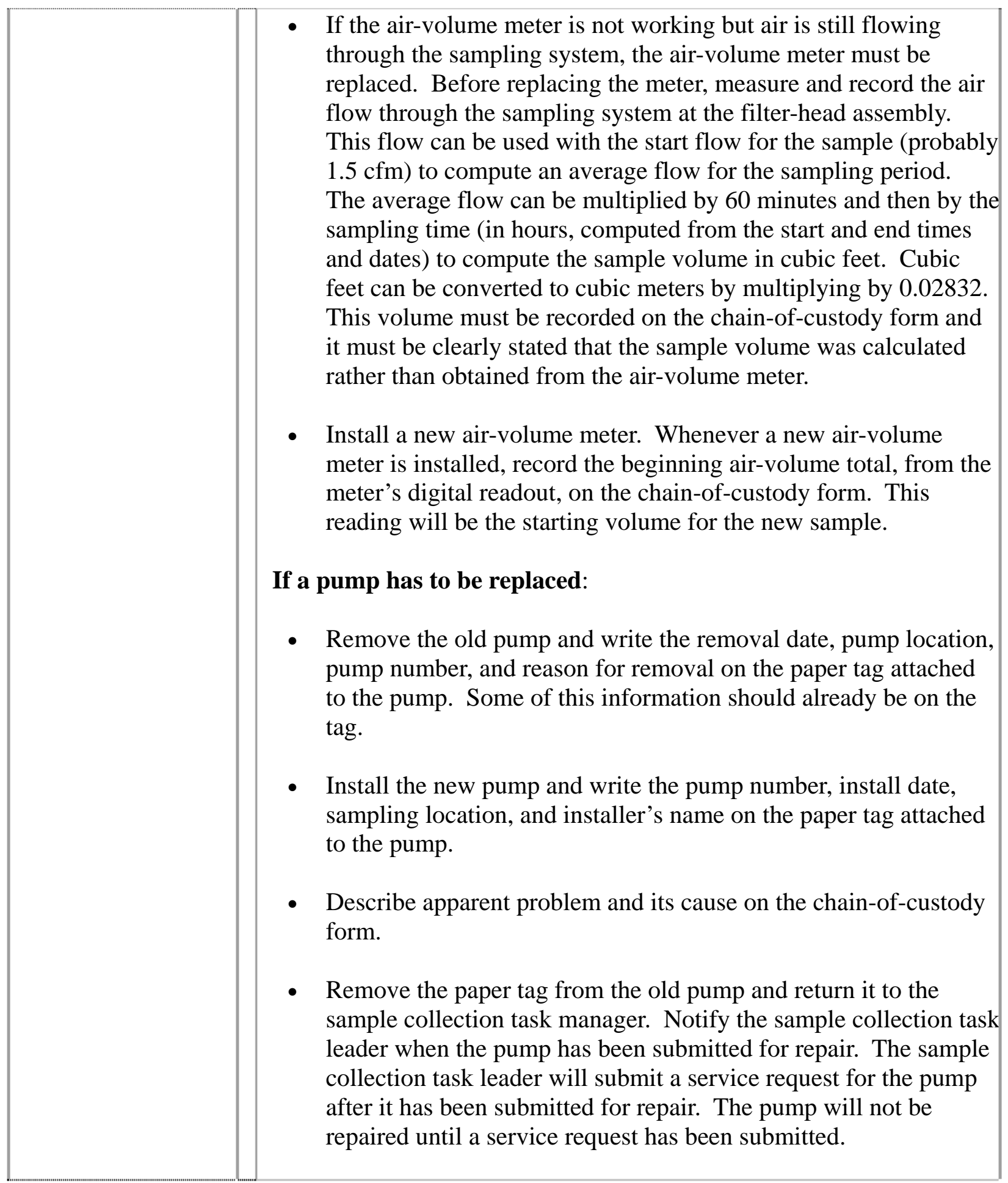




\begin{tabular}{|c|c|}
\hline & $\begin{array}{l}\text { If the air flow rate cannot be adjusted to } \mathbf{1 . 5} \mathbf{~ c f m : ~} \\
\text { - Detach the flow controller from air-volume meter and use the air } \\
\text { flow calibrator to determine if either the meter or flow controller } \\
\text { is causing a flow restriction. If either item is causing a restriction, } \\
\text { replace it, and record on the chain-of-custody form what was } \\
\text { done, and why. } \\
\text { - If neither the air-volume meter nor flow controller is causing a } \\
\text { restriction, replace the pump. }\end{array}$ \\
\hline $\begin{array}{l}\text { STATION } \\
\text { MAINTENANCE }\end{array}$ & $\begin{array}{l}\text { Maintenance activities should be conducted as necessary, or at the } \\
\text { direction of the sample collection task manager. } \\
\text { - Check that the overall sampling system is properly configured } \\
\text { (see Figure 3.0.1). } \\
\text { - Replace worn, brittle, or cracked tubing. } \\
\text { - Check for loose connections, bad disconnects, etc. Repair or } \\
\text { replace components as necessary. } \\
\text { - Periodically wipe excess dust from the entire system, and clean } \\
\text { out the hutch. } \\
\text { Test the GFCI (located inside the sampling hutch) quarterly. To } \\
\text { do this, press the test button on the GFCI. The pump should stop } \\
\text { running. Next press the reset button. The pump should resume } \\
\text { operation. If the pump does not stop or restart during this test, } \\
\text { contact the sample collection task manager. Note that if there is a } \\
\text { second GFCI located inline with the sample hutch, it may also } \\
\text { trip during testing. }\end{array}$ \\
\hline $\begin{array}{l}\text { COMPLETING } \\
\text { CHAIN-OF- } \\
\text { CUSTODY FORMS } \\
\text { AND SUBMITTING } \\
\text { SAMPLES FOR } \\
\text { ANALYSES }\end{array}$ & $\begin{array}{l}\text { See Section 8.1, Chain-of-Custody Forms, for requirements for } \\
\text { completing chain-of-custody forms and submitting samples to an } \\
\text { analytical laboratory. }\end{array}$ \\
\hline
\end{tabular}




\subsection{ATMOSPHERIC TRITIUM SAMPLES}

\begin{tabular}{|l|l|l|l|l|l}
\hline INTRODUCTION & $\begin{array}{l}\text { Atmospheric tritium }\left({ }^{3} \mathrm{H}\right) \text { collection columns are placed at locations that } \\
\text { could be impacted by Hanford Site operations. Silica gel in the } \\
\text { columns is used to collect }{ }^{3} \mathrm{H} \text { in the form of water vapor (HTO). } \\
\text { Tritium samples are collected and analyzed monthly. }\end{array}$ \\
\begin{tabular}{l|l} 
EQUIPMENT AND \\
SUPPLIES
\end{tabular} & $\begin{array}{l}\text { When collecting tritium samples, the following equipment may be } \\
\text { needed in addition to the equipment needed for collecting air-particulate } \\
\text { samples: }\end{array}$
\end{tabular}

- Fresh silica-gel columns. Fresh gel can be identified by the bright blue color of the gel.

- An extra tritium flow meter.

- $\quad$ Extra metering valves.

- $\quad$ A hand held vacuum pump/pressure gauge.

- Glass-fiber filters (used as pre-filters for the tritium sampler).

BEFORE SAMPLE COLLECTION
Pick up a supply of fresh, unexposed silica-gel column assemblies from the analytical laboratory (as many as the laboratory has available). This will maintain an adequate supply of fresh assemblies at Sigma 5 and in the field sampling truck. If there are not sufficient assemblies to pick up, notify the sample collection task leader or the data management task leader.

\section{Prior to using a silica gel assembly:}

- Check the quick-disconnect fittings on each assembly for ease of use. Apply a greaseless lubricant to the fittings as needed.

- $\quad$ Check the assembly for leaks. This can be done in the morning before leaving for the field, or several days in advance. Keep columns that have been leak checked in one location, and unchecked columns in another location.

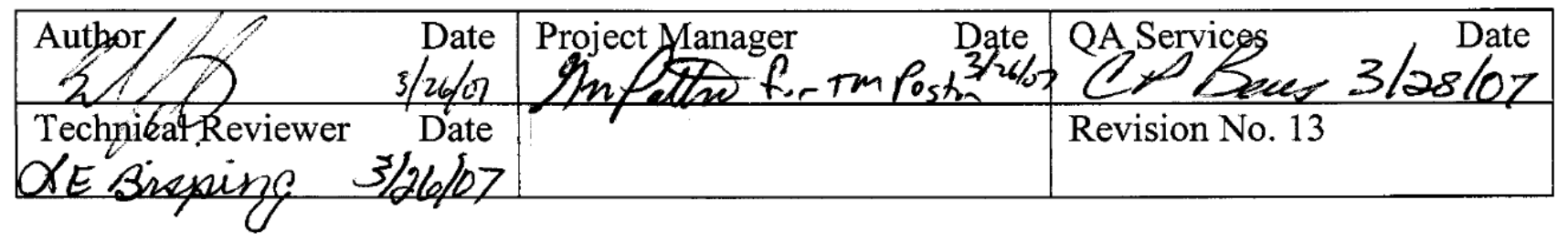


- Use a vacuum pump/pressure gauge to check the column assembly for leaks. Evacuate the air from the columns to about 10 in. Hg vac. Watch the gauge for 15 to 30 seconds. If the pressure has not dropped below 5 in. Hg vac, the column is air tight and may be used.

\section{If the gauge indicates a leak:}

- Be sure that the caps on the columns are tight. The most common location for a leak is the caps. Cleaning and lightly greasing the gaskets helps provide an airtight seal. Other locations to check for leaks include the fittings that screw into the columns (around the threads), and where the plastic tubing is attached to these fittings. Also look for small cracks that may have developed in the plastic case.

NOTE: The gaskets in the caps should be flat, not round like an $\mathrm{O}$-ring. The O-ring type gaskets are more prone to leaks.

- If the leak cannot be eliminated, label the assembly so that it won't be used by mistake and return the assembly to the laboratory so that the silica gel can be removed. Silica gel is considered a hazardous material and cannot be thrown in the trash.

\section{SAMPLE COLLECTION}

\section{At the sampling location:}

- Observe the silica-gel column assembly in use. The silica gel at the air inlet should be lighter in color (pinkish or a light blue), while the gel at the outlet should remain dark blue. Note on the chain-of-custody form any unusual color change patterns such as: no color change from blue to light blue (indicates no sample collected), the gel in the entire assembly is light blue or pink (indicates the gel is saturated): or the gel in the second and/or third columns is lighter in color than the gel in the first column (indicates a leak). If an unusual color pattern is noted, record the observation on the chain-of-custody form and notify the sample collection task manager or air task manager, who will determine if the sample should be submitted to the analytical laboratory

\section{If the pump is running and the sampling system appears to be operating normally:}

- Begin the collection of the tritium sample before collecting the particulate sample. If there is a problem with the system, follow the TROUBLESHOOTING procedures in Section 3.1.

- $\quad$ Remove the pre-filter assembly from the tritium sample inlet. 
- Attach the pre-filter assembly to the flow calibrator inlet.

- Attach the flow calibrator to the tritium sample inlet. Air flow through the calibrator should be from bottom to top.

- Hold the flow calibrator vertical and read the as found flow rate. Record this reading in the End Vol/Flow field on the chain-ofcustody form.

- Enter all pertinent sampling information on the chain-of-custody form and sample label. Exposure hours for a normal 4-week sample should be around 672 .

- If the timer is faulty, but the system is still running, exposure hours can be calculated based on sample start and stop dates and times.

\section{If the exposure hours are less than 336:}

- Stop the collection of the tritium sample and start the collection of the particulate sample.

- Upon return to the office, notify the sample collection task manager or air task manager, who will determine if the sample should be submitted to the analytical laboratory.

\section{After the particulate sample has been collected:}

- Remove the exposed column assembly from the air hutch by disconnecting the quick disconnect fittings at the inlet and outlet of the column assembly.

- Attach the sample label to the exposed sample with tape. Do not stick the label directly onto silica gel column.

- Install the fresh silica gel column assembly so that air flow through the columns is from top left to bottom right.

- Double check all columns to be sure the quick disconnect fittings are secure and the column lids are tight.

- Change the glass-fiber filter in the pre-filter assembly.

- Attach new pre-filter assembly to the flow calibrator.

- Attach flow calibrator to the sample inlet. Be sure that the ball moves freely in the flow calibrator. 
- If necessary, adjust the flow rate to $190 \mathrm{~mL} / \mathrm{min}$ with the in-line flow control valve.

- Record this flow rate (Next Flow) on the chain-of-custody form.

- Remove flow calibrator and replace the pre-filter assembly (with rain guard) at tritium sample inlet.

\section{Double check that:}

- All quick disconnect fittings are secure.

- The gel columns are vertical and the air flow if from top left to bottom right.

COMPLETING CHAIN-OFCUSTODY FORMS AND SUBMITTING SAMPLES FOR ANALYSES
See Section 8.1, Chain-of-Custody Forms, for requirements for completing chain-of-custody forms and submitting samples to an analytical laboratory. 


\subsection{IODINE-129 SAMPLES}

\begin{tabular}{|c|c|}
\hline INTRODUCTION & $\begin{array}{l}\text { Due to an instrument failure at the analytical laboratory, it is currently } \\
\text { not possible to analyze SESP samples for low levels of iodine- } 129 \text {. } \\
\text { Therefore, the collection of ambient air samples for iodine- } 129 \\
\text { analyses has been halted until SESP personnel can locate another } \\
\text { laboratory with a similar low-level analytical capability. This sample } \\
\text { collection procedure will remain in this manual until a new laboratory } \\
\text { is located or it is determined by project personnel that the procedure is } \\
\text { no longer needed. } \\
\text { Charcoal cartridge samples for monitoring atmospheric iodine-129 are } \\
\text { collected monthly at a few selected locations and these monthly } \\
\text { samples are combined and analyzed quarterly. }\end{array}$ \\
\hline $\begin{array}{l}\text { EQUIPMENT AND } \\
\text { SUPPLIES }\end{array}$ & $\begin{array}{l}\text { When collecting iodine-129 samples, the following equipment and } \\
\text { supplies may be needed in addition to the equipment used for } \\
\text { collecting air-particulate samples (see Section 3.1): } \\
\text { - New charcoal cartridges loaded in cartridge holders. } \\
\text { - Plastic bags to put the exposed cartridge holders in. }\end{array}$ \\
\hline $\begin{array}{l}\text { SAMPLE } \\
\text { COLLECTION }\end{array}$ & $\begin{array}{l}\text { - Open the hutch. If the pump is running, follow these procedures. } \\
\text { If not, consult the troubleshooting procedures in Section 3.1. } \\
\text { - Check the digital (mechanical) display on the air-volume meter to } \\
\text { see if the black and white 'pinwheel' is spinning. If the pinwheel } \\
\text { is spinning, continue with this procedure. If the pinwheel is not } \\
\text { spinning, skip to the troubleshooting procedures in Section 3.1. } \\
\text { - Enter all pertinent sampling information on the chain-of-custody } \\
\text { form and sample label. }\end{array}$ \\
\hline
\end{tabular}

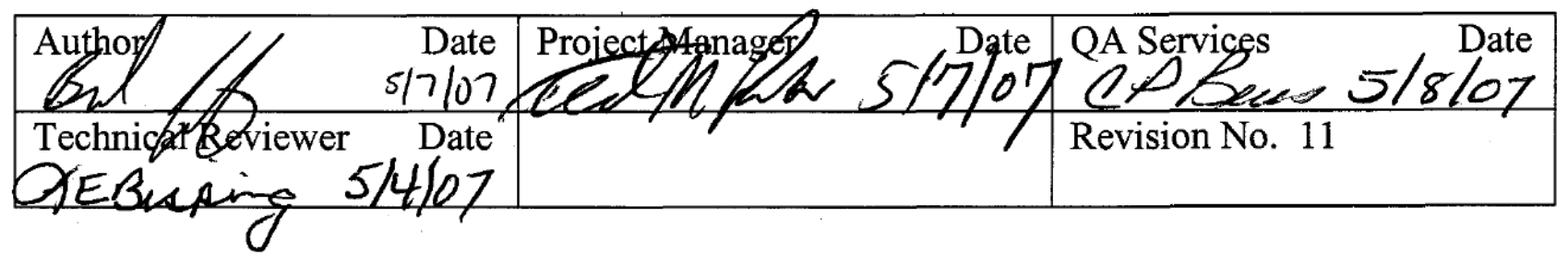




\begin{tabular}{|c|c|}
\hline & $\begin{array}{l}\text { - Record the first four digits of the volume total from the air- } \\
\text { volume meter's digital readout (cubic meters) in the End } \\
\text { Vol/Flow field on the chain-of-custody form. If the air volume } \\
\text { appears abnormally high or low, consult the } \\
\text { TROUBLESHOOTING procedures in Section } 3.1 \text {. } \\
\text { - } \text { Remove the exposed cartridge holder assembly. } \\
\text { - Place the exposed assembly in a plastic bag and seal the bag with } \\
\text { tape. Put the label on the plastic bag. } \\
\text { Connect a flow calibrator to the new charcoal cartridge holder } \\
\text { and to the sample inlet and measure the air flow rate. If the air } \\
\text { flow is not } 1.5 \text { cfm, adjust the flow control valve until the air flow } \\
\text { rate is } 1.5 \text { cfm. } \\
\text { If the flow cannot be adjusted to } 1.5 \text { cfm, consult the } \\
\text { troubleshooting procedures in Section 3.1. } \\
\text { Remove the flow calibrator, and attach the new charcoal cartridge } \\
\text { holder to the sample inlet. } \\
\text { NOTE: Charcoal assembly glass-fiber pre-filters are to be } \\
\text { replaced bi-weekly when the air-particulate filters are collected. } \\
\text { The exposed pre-filters should be discarded. Pre-filters on } \\
\text { charcoal assemblies collected for analysis should be left in the } \\
\text { cartridge assembly. }\end{array}$ \\
\hline $\begin{array}{l}\text { COMPLETING } \\
\text { CHAIN-OF- } \\
\text { CUSTODY FORMS } \\
\text { AND SUBMITTING } \\
\text { SAMPLES FOR } \\
\text { ANALYSES }\end{array}$ & $\begin{array}{l}\text { See Section 8.1, Chain-of-Custody Forms, for further requirements for } \\
\text { completing chain-of-custody forms and submitting samples to an } \\
\text { analytical laboratory. }\end{array}$ \\
\hline
\end{tabular}




\subsection{SURFACE-WATER AND SEDIMENT SAMPLING}

SESP personnel routinely collect water samples from the Columbia River near the Hanford Site, two offsite irrigation systems that obtain water from the Columbia River, Hanford Reach riverbank springs, and two onsite ponds. Sediment samples are also routinely collected on and around the Hanford Site. Procedures for collecting routine water and sediment samples are discussed in the following sections:

- $\quad$ Irrigation water, pond water, and pond sediment (Section 4.1).

- Columbia River composite water samples (Section 4.2).

- Columbia River continuous water samples (filter/resin) (Section 4.3).

- $\quad$ Transect and near-shore water samples (Section 4.4).

- $\quad$ Riverbank spring water and sediment (Section 4.5).

- Columbia River sediment (Section 4.9).

Analytical results from these samples are used to monitor the concentrations of Hanford produced contaminants, determine compliance with applicable state and federal contaminant concentration standards, evaluate the effectiveness of onsite effluent controls and monitoring systems, and evaluate the potential dose to the public from the surface water and sediment exposure pathways.

Other activities may be conducted in association with the collection of water and sediment samples. These activities may include:

- Conductivity measurement (Section 4.6).

- $\quad \mathrm{pH}$ measurement (Section 4.7).

- $\quad$ Filtered water samples (Section 4.8).

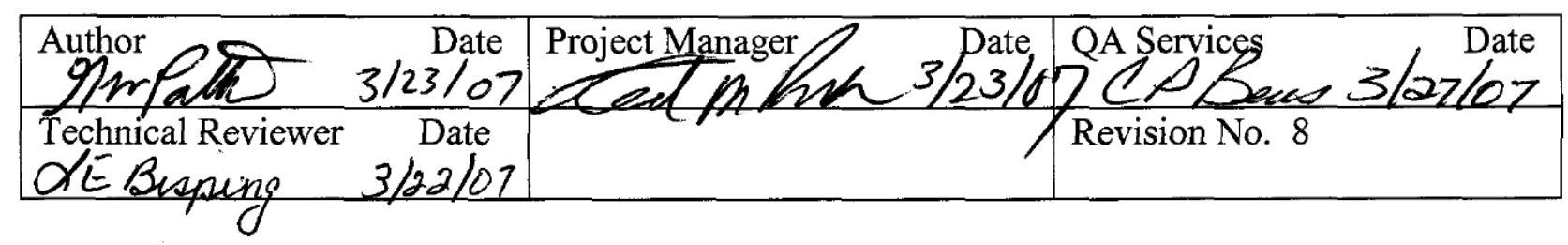




\subsection{IRRIGATION WATER, POND WATER, AND POND SEDIMENT}

\begin{tabular}{|c|c|}
\hline INTRODUCTION & $\begin{array}{l}\text { Discrete (grab) water and sediment samples from onsite ponds, and water } \\
\text { from offsite irrigation systems are collected to characterize water and } \\
\text { sediment quality at a single point in time and space. Discrete water } \\
\text { samples are generally collected where the water does not flow } \\
\text { continuously, or when water quality characteristics are relatively constant, } \\
\text { or when the parameters to be analyzed are likely to change over an } \\
\text { extended sampling or sample storage period. In addition, discrete } \\
\text { samples are collected to monitor non-radiological water quality } \\
\text { parameters and to study the spatial variability of contaminant } \\
\text { concentrations. }\end{array}$ \\
\hline PERSONNEL & $\begin{array}{l}\text { Field sampling must be conducted by personnel who have received } \\
\text { training on these sampling procedures and are familiar with the sampling } \\
\text { equipment. } \\
\text { It is estimated that this procedure requires one (1) person for an efficient } \\
\text { operation. }\end{array}$ \\
\hline $\begin{array}{l}\text { EQUIPMENT AND } \\
\text { SUPPLIES }\end{array}$ & $\begin{array}{l}\text { The following equipment and supplies may be needed for the collection } \\
\text { of pond and irrigation water and pond sediment samples: } \\
\text { - A cellular telephone. } \\
\text { - A portable scale for weighing sediment. } \\
\text { - } \quad \text { Sample containers - see chain-of-custody form or sample label for } \\
\text { container size requirements. } \\
\text { - Extra containers, buckets, or pump to be used as needed to transfer } \\
\text { - } \text { water and/or sediment from the water source to the sample container. } \\
\text { - Tip boots or waist waders. } \\
\text { - A rowels. }\end{array}$ \\
\hline
\end{tabular}

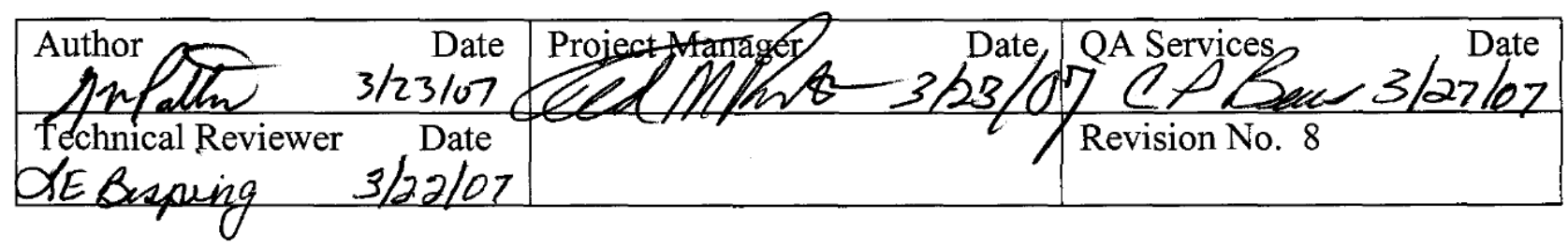




\begin{tabular}{|c|c|}
\hline & $\begin{array}{l}\text { - } \text { A boat hook. } \\
\text { - } \text { Sample labels and chain-of-custody paperwork. } \\
\text { - } \quad \text { Evidence tape. } \\
\text { - } \quad \text { Medium sized plastic bags (for sediment). } \\
\text { - } \text { Disposable gloves. } \\
\text { - Clean water for hand washing after sampling. } \\
\text { - A permanent marking pen. }\end{array}$ \\
\hline $\begin{array}{l}\text { WEST LAKE } \\
\text { WATER SAMPLES }\end{array}$ & $\begin{array}{l}\text { Upon arrival at the lake, leave the vehicle on or near the road. Do not } \\
\text { drive off road near the water or onto the dry bed of the lake. There is } \\
\text { water underneath the dry sediment and a parked vehicle can sink through } \\
\text { the dry sediment into mud. } \\
\text { Observe the sampling location and record on the chain-of-custody form } \\
\text { any unusual conditions. The amount of water in West Lake varies } \\
\text { seasonally. Sometimes there is a small amount of surface water visible; } \\
\text { sometimes the water is hidden beneath a layer of crusted sediment. } \\
\text { If surface water is visible: } \\
\text { - Carry a cell phone while sampling. It may be needed if you get } \\
\text { stuck in the sediment. } \\
\text { - Walk carefully to the edge of the water. Watch out for soft sediment. } \\
\text { It may be necessary to constantly shift your feet to keep from } \\
\text { sinking in the sediment and getting stuck. } \\
\text { - If the sediment near the water is too soft to walk in, tape a plastic } \\
\text { sample container to the boat hook (use green tape) to make a } \\
\text { sampling scoop, walk as close to the water as possible, and use the } \\
\text { container on the boat hook to scoop water from the pond. Rinse the } \\
\text { scoop three times with lake water before collecting the sample. } \\
\text { Try not to disturb the sediment beneath the water surface. Water } \\
\text { samples should be free of sediment and surface debris if at all } \\
\text { possible. }\end{array}$ \\
\hline
\end{tabular}




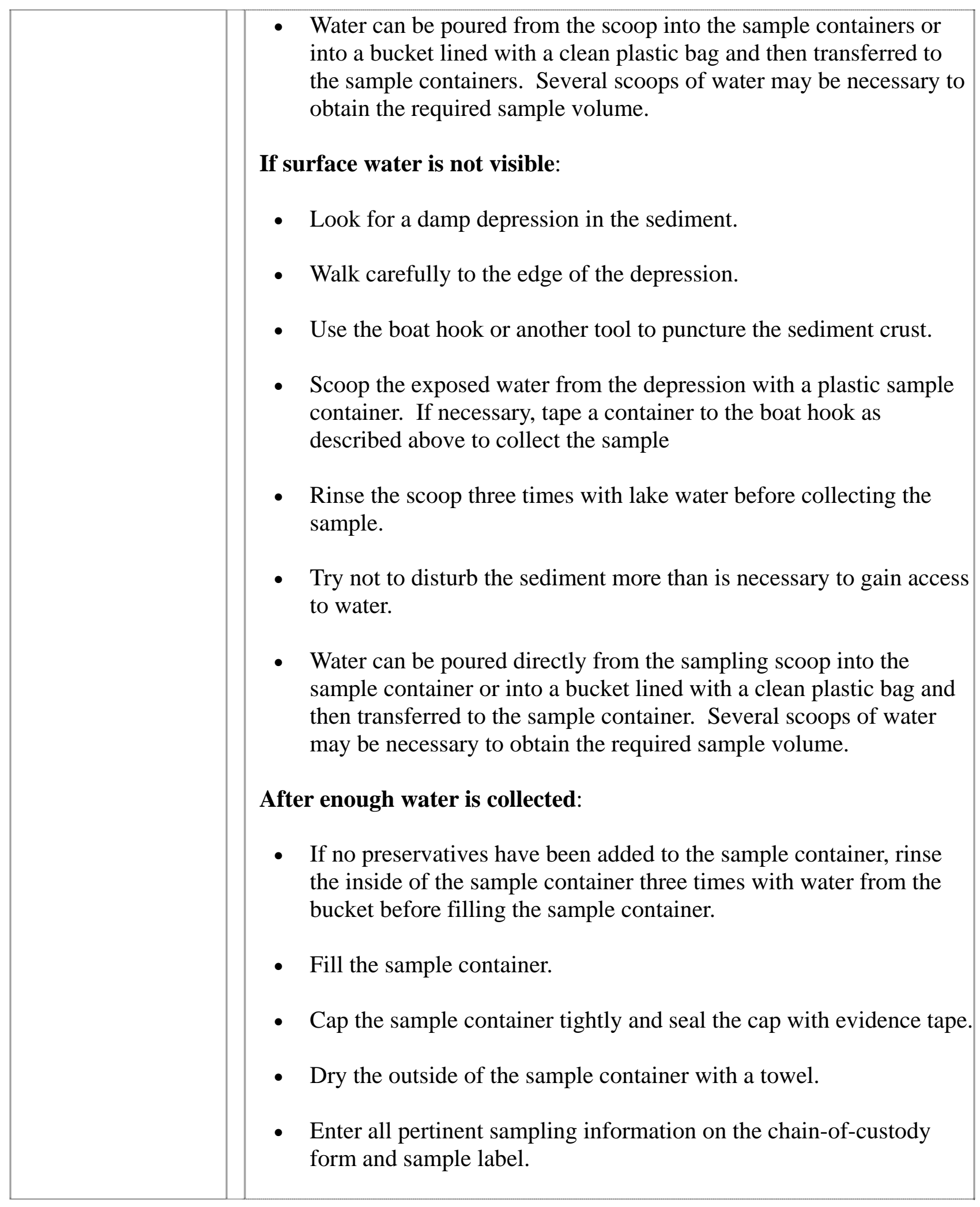




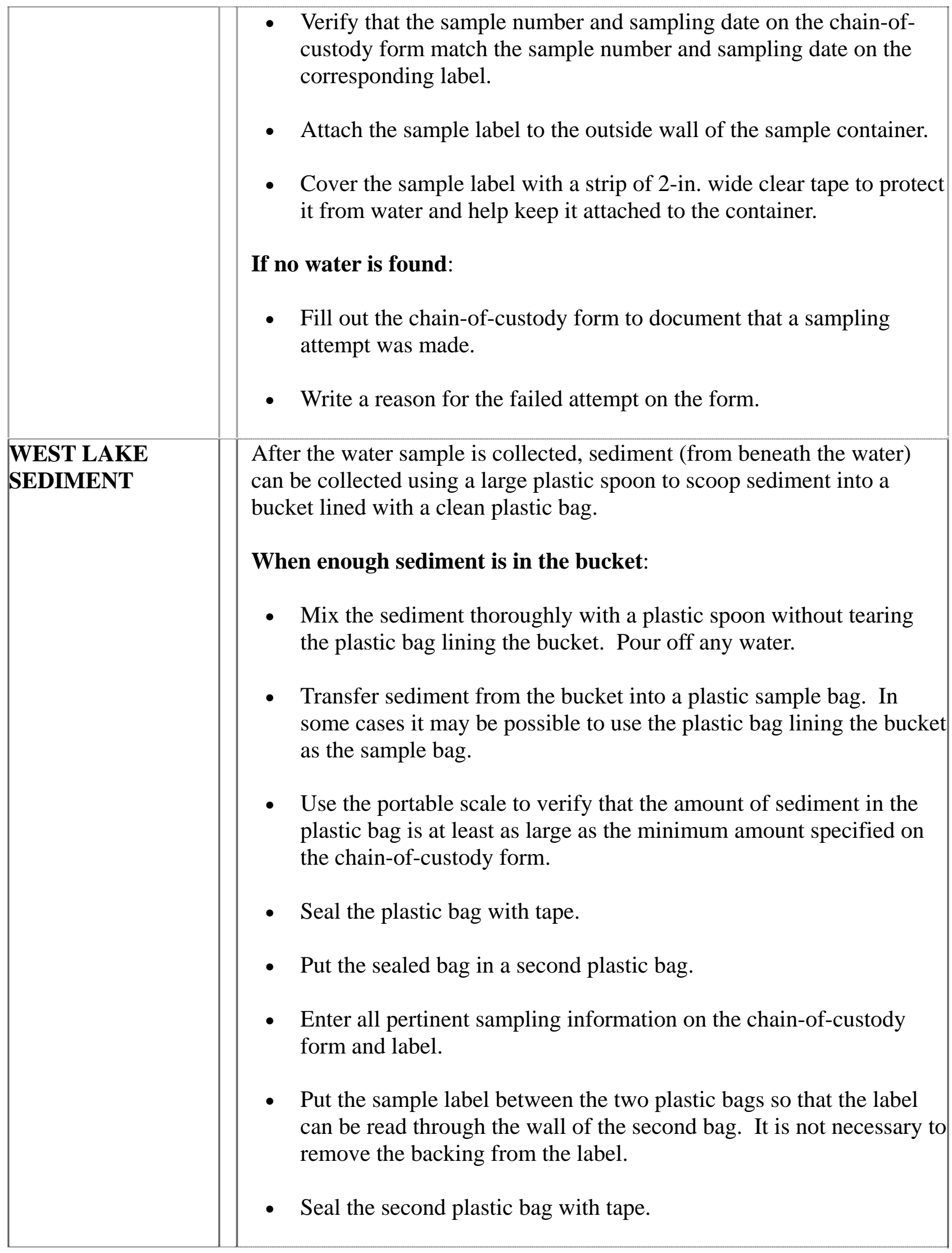


FFTF POND WATER

Water at the Fast Flux Test Facility is not collected from the discharge pond but is obtained from the concrete weir box that empties into the discharge pond. The weir box is deep and the water in the box is shallow.

- $\quad$ To reach the water in the weir box, attach a plastic container to a boat hook to produce a sampling scoop. Rinse the scoop three times with water from the weir box before sampling.

- Water scooped from the weir box can be poured directly into the sample container or, if more convenient, into a bucket lined with a clean plastic bag and then transferred to the sample container. Multiple scoops from the weir box may be needed to achieve the required sample volume.

NOTE: The water is usually too shallow to fully immerse the container so several scoops with the plastic container are generally needed to collect enough water for a sample.

- When enough water has been collected in a clean bucket, refer to the section above "After enough water is collected:" to complete the sampling effort.

IRRIGATION WATER
Irrigation water is collected at two locations off the site. One sample is collected from an irrigation ditch. The other sample is collected from a faucet on an irrigation water line.

The water sample from the ditch is collected at a location where the ditch bank is dirt, the bank slope is not steep, the water in the canal is relatively shallow ( $<2$ feet), and the water flow is slow.

- Scoop water from the ditch using a plastic sample container, or by attaching a sample container to a boat hook and scooping water from the ditch.

- $\quad$ Rinse the scoop three times with irrigation water before collecting the sample.

- Water obtained with the scoop can be poured directly into the sample container, or, if more convenient, poured into a bucket lined with a clean plastic bag and then into the sample container.

- $\quad$ Several scoops from the ditch may be needed to obtain the required sample volume. 


\begin{tabular}{|c|c|}
\hline & $\begin{array}{l}\text { - When enough water has been collected in the bucket or container, } \\
\text { refer to the section above "After enough water is collected:" to } \\
\text { complete the sampling effort. } \\
\text { The water sample from the faucet is collected from a water supply line } \\
\text { at an irrigated field. } \\
\text { - Flush the faucet thoroughly, generally } 2 \text { to } 3 \text { minutes, before } \\
\text { collecting the sample. } \\
\text { - When the sample container is filled, refer to the section above "After } \\
\text { enough water is collected:” to complete the sampling effort. }\end{array}$ \\
\hline $\begin{array}{l}\text { CHAIN-OF- } \\
\text { CUSTODY FORM } \\
\text { AND SAMPLE } \\
\text { SUBMISSION } \\
\text { REQUIREMENTS }\end{array}$ & $\begin{array}{l}\text { See Section 8.1, Chain-of-Custody Forms, for further requirements for } \\
\text { completing chain-of-custody forms and submitting samples to an } \\
\text { analytical laboratory. }\end{array}$ \\
\hline
\end{tabular}




\subsection{COLUMBIA RIVER COMPOSITE WATER SAMPLES}

\begin{tabular}{|c|c|}
\hline INTRODUCTION & $\begin{array}{l}\text { A composite water sample is a mixture of grab samples collected at a } \\
\text { specific location at regular intervals throughout a sampling period. The } \\
\text { individual grab samples may be collected manually; however, automatic } \\
\text { sampling equipment is often used. Composite samples reflect the average } \\
\text { characteristics during the sampling period and may be used to calculate } \\
\text { mass contaminant loadings per unit time. } \\
\text { The SESP uses automatic composite samplers on the Columbia River at } \\
\text { Priest Rapids Dam (operated by the Grant Count PUD) and the Richland } \\
\text { pump house (operated by the city of Richland). } \\
\text { NOTE: Gate keys are needed at both locations to gain access to the } \\
\text { samplers. All PUD or city of Richland postings and requirements must be } \\
\text { followed at these two locations. } \\
\text { Figure } 4.2 .1 \text { shows a flow diagram summarizing the composite water } \\
\text { sampling procedure. }\end{array}$ \\
\hline PERSONNEL & $\begin{array}{l}\text { Field sampling must be conducted by personnel who have received } \\
\text { training on these sampling procedures and are familiar with the sampling } \\
\text { equipment. } \\
\text { It is estimated that this procedure requires one (1) person for efficient } \\
\text { operation. }\end{array}$ \\
\hline $\begin{array}{l}\text { EQUIPMENT AND } \\
\text { SUPPLIES }\end{array}$ & $\begin{array}{l}\text { The following equipment and supplies may be needed for the collection } \\
\text { of composite samples: } \\
\text { - A 10-L (2.5-gal) plastic container with cap (used when collecting the } \\
\text { composite sample and for submitting the composite sample to the } \\
\text { analytical laboratory). } \\
\text { - A } 500-\text { ml plastic container with cap for collecting a sample for } \\
\text { iodine-129 analysis. } \\
\text { - A 1-L plastic container with cap for a weekly WDOH sub-sample } \\
\text { (January and June only). }\end{array}$ \\
\hline
\end{tabular}

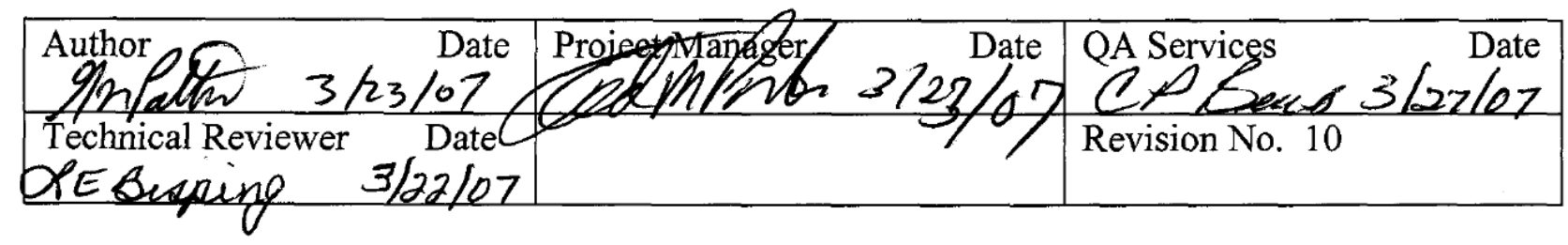




\begin{tabular}{|c|c|}
\hline & $\begin{array}{l}\text { - A 4-L plastic container with cap for the WDOH composite of four } \\
\text { 1-L weekly samples (January and June only). } \\
\text { - A plastic 100-mL graduated cylinder for measuring water flows. } \\
\text { - A watch for determining water flow rates. } \\
\text { - } \quad \text { Miscellaneous tools for making minor system repairs. } \\
\text { - } \quad \text { A roll of 2-in. wide clear tape to cover (protect) sample labels. } \\
\text { - A permanent marking pen. }\end{array}$ \\
\hline $\begin{array}{l}\text { SAMPLE } \\
\text { COLLECTION }\end{array}$ & $\begin{array}{l}\text { A diagram of the composite sampling system is shown in Figure 4.2.2. } \\
\text { The procedure for collecting a composite water sample is as follows: } \\
\text { - } \quad \text { Proceed to the sampling location. } \\
\text { Observe the sample container in the composite sampler. The } \\
\text { container should be nearly full (8-10 L). } \\
\text { Remove the filled sample container and install and tighten its cap } \\
\text { firmly. } \\
\text { NOTE: If the automatic sampler does not collect a large enough } \\
\text { sample (i.e., the sample container is less than half full), a grab } \\
\text { sample should be taken. The grab sample may be taken from the } \\
\text { water-supply hose to the sample reservoir or, if the former is not } \\
\text { possible, at the Richland pump house, directly from the river at the } \\
\text { end of the public dock located just downstream from the pump } \\
\text { house. Prior to sample collection, the inside of the sample container } \\
\text { should be rinsed three times with the water being sampled. Indicate } \\
\text { on the chain-of-custody form that a grab sample, rather than a } \\
\text { composite sample, was collected. Record the sample collection } \\
\text { location (e.g., water-supply hose or public dock) in the description } \\
\text { column on the chain-of-custody form. } \\
\text { Enter all pertinent sampling information on the chain-of-custody } \\
\text { form and sample label. }\end{array}$ \\
\hline
\end{tabular}




\begin{tabular}{|c|c|}
\hline & $\begin{array}{l}\text { - If scheduled, carefully fill the } 500 \text {-mL container (iodine-129) and } \\
\text { the 1-L container (WDOH) with water from the 10-L composite } \\
\text { sample container. The 500-mL container is delivered to the } \\
320 \text { Building and the 1-L container is stored in a locked refrigerator } \\
\text { or cooler at the Sigma } 5 \text { Building until it is transferred to the WDOH. } \\
\text { - Verify that the sample number and sampling date on the chain-of- } \\
\text { custody form match the sample number and sampling date on the } \\
\text { corresponding sample label. } \\
\text { - Attach the sample labels to the sample containers. } \\
\text { Cover the sample labels with strips of the 2-in. wide clear tape to } \\
\text { protect them from water and help keep them attached to the } \\
\text { containers. } \\
\text { Note any unusual conditions on the chain-of-custody form, (e.g., } \\
\text { equipment failures, unusually high amounts of suspended solids in } \\
\text { the sample, an unusually small or large sample volume, an unusually } \\
\text { small or large sample aliquot volume). } \\
\text { NOTE: When scheduled, sub-samples are taken from the overall } \\
\text { composite sample and relinquished to the appropriate laboratory or } \\
\text { agency (e.g., Washington State Department of Health [WDOH]). }\end{array}$ \\
\hline $\begin{array}{l}\text { ALIQUOT } \\
\text { VOLUME CHECK }\end{array}$ & $\begin{array}{l}\text { Composite samples consist of aliquots of a certain volume that are } \\
\text { automatically collected at established times during the interval between } \\
\text { sample collections. Aliquot volume must be verified, and adjusted if } \\
\text { necessary (rare), each time a sample is collected. } \\
\text { The procedure for verifying aliquot volume is as follows: } \\
\text { - Turn off power to the sampler then immediately turn it back on. The } \\
\text { power switch is located on the control panel beside the measuring } \\
\text { chamber (see Figure } 4.2 .2 \text { ). } \\
\text { - Place the graduated cylinder under the sample outlet tube in the } \\
\text { automatic sampler (outlet to the } 10 \text {-L composite sample container). } \\
\text { - Observe the aliquot volume collected in the graduated cylinder. } \\
\text { Volume should be } 50 \text { to } 60 \text { mL. } \\
\text { Record the aliquot volume collected in the appropriate field on the } \\
\text { chain-of-custody form. }\end{array}$ \\
\hline
\end{tabular}




\begin{tabular}{|c|c|}
\hline & $\begin{array}{l}\text { - If the aliquot volume is } 50 \text { to } 60 \mathrm{~mL} \text {, proceed to "REINSTALLING } \\
\text { THE SAMPLE CONTAINER." } \\
\text { - If the aliquot volume is less than } 50 \mathrm{~mL} \text { or greater than } 60 \mathrm{~mL} \text {, } \\
\text { proceed to "ALIQUOT VOLUME ADJUSTMENT." }\end{array}$ \\
\hline $\begin{array}{l}\text { ALIQUOT } \\
\text { VOLUME } \\
\text { ADJUSTMENT }\end{array}$ & 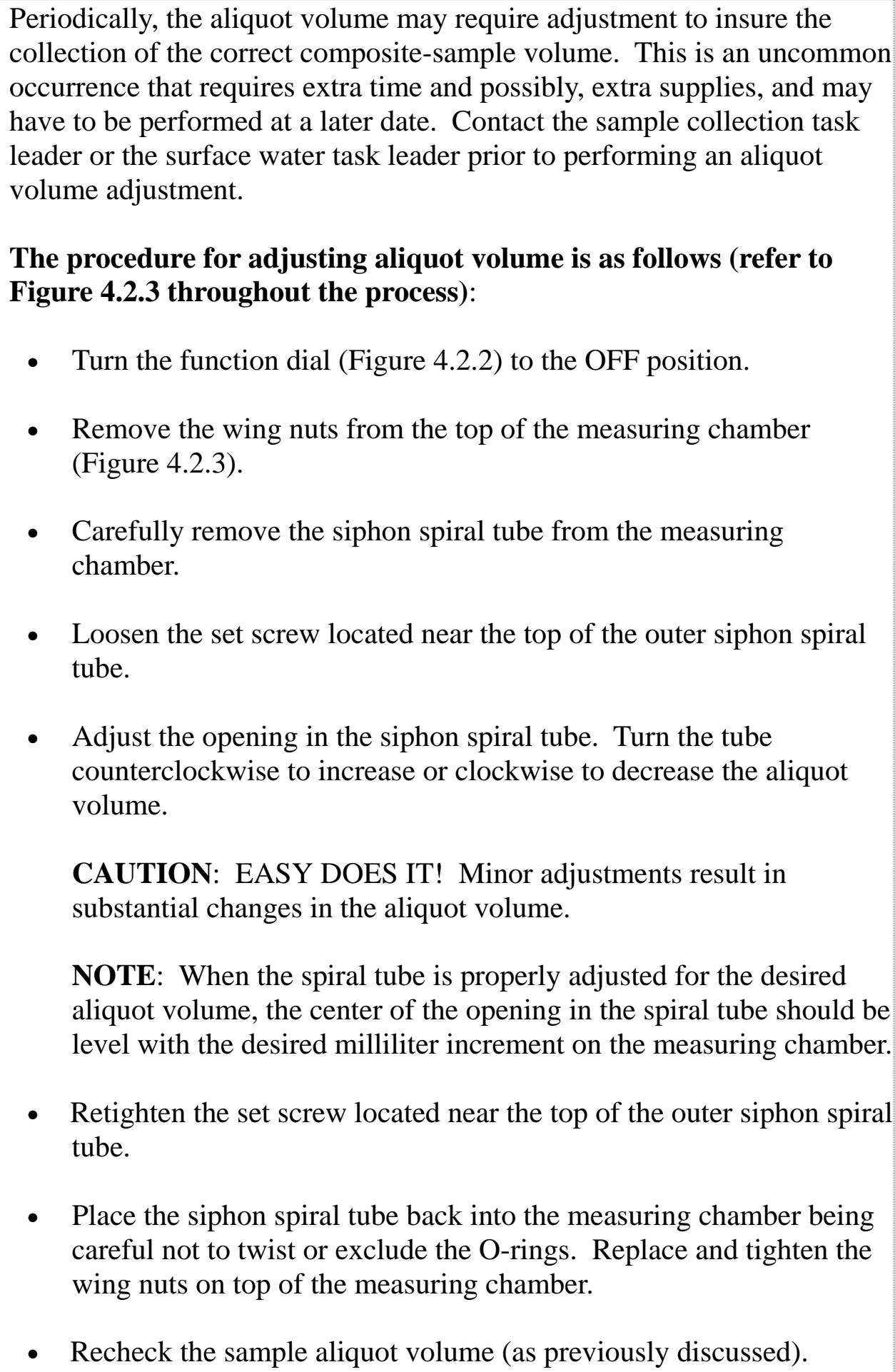 \\
\hline
\end{tabular}




\begin{tabular}{|l|l|l|l|}
\hline & $\begin{array}{l}\text { Continue repeating these steps until the desired volume (50 to } \\
60 \mathrm{~mL} \text { ) is obtained. }\end{array}$ \\
\hline THE SAMP the function dial (Figure 4.2.2) from the OFF position back to \\
the TIME position.
\end{tabular}




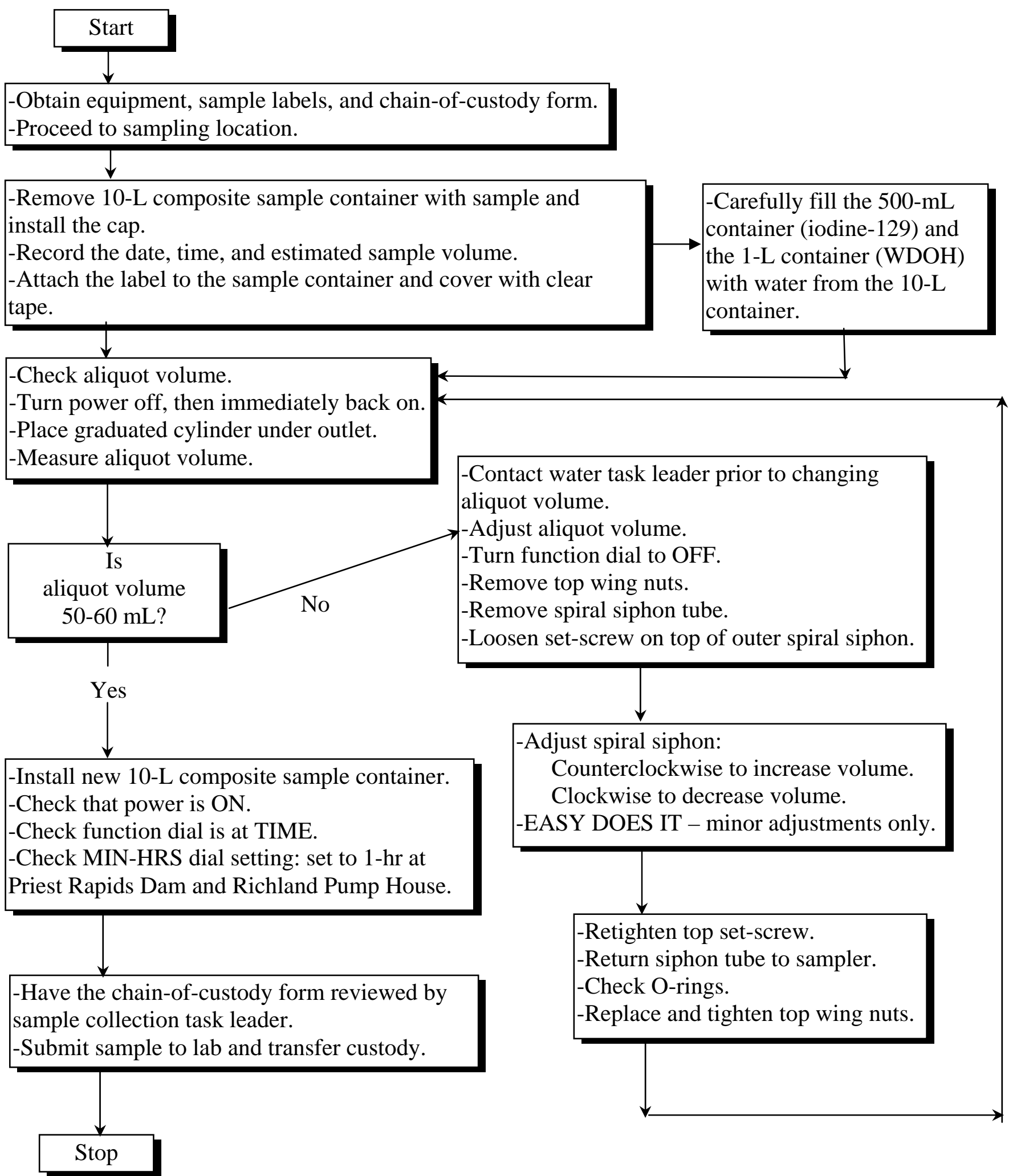

Figure 4.2.1. Flow Chart Summarizing the Composite Water Sampling Procedure 
Section 4.2

Issued: 03-07

Supersedes: 04-03

PNL-MA-580

Page 7

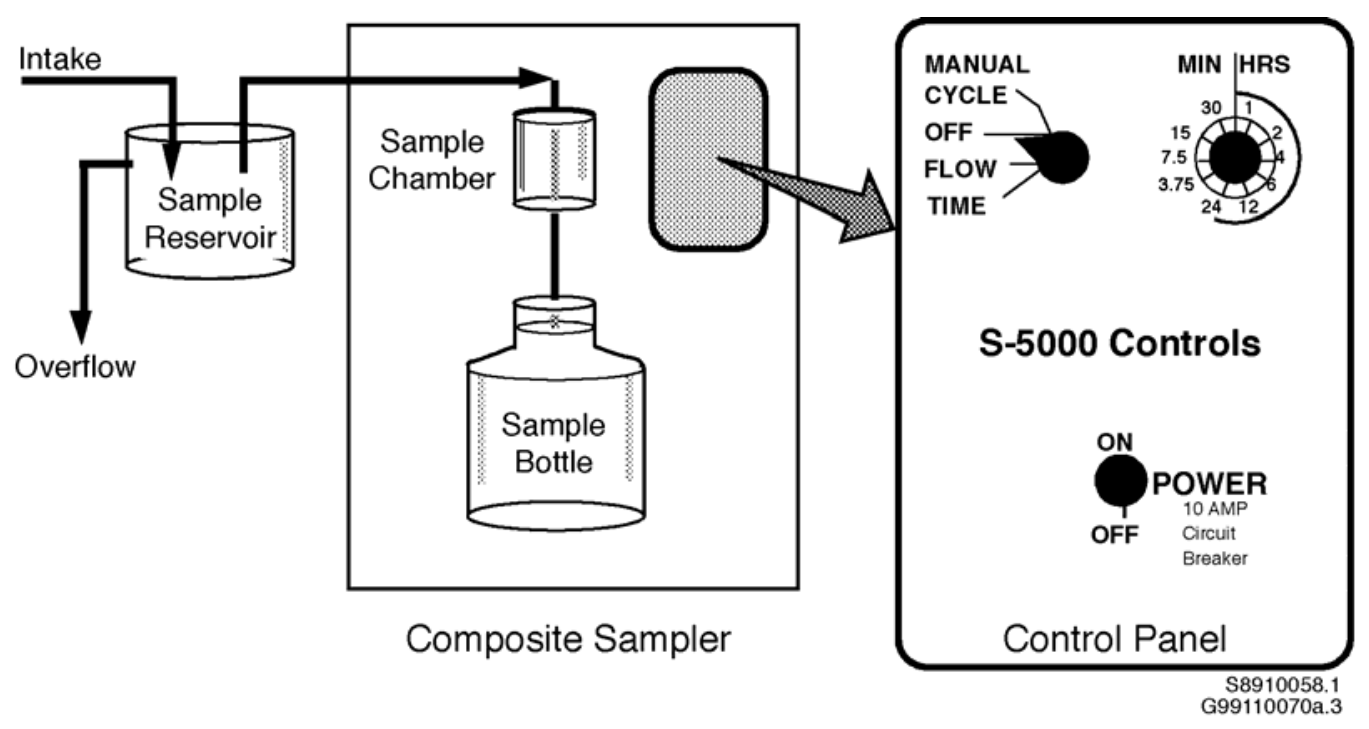

Figure 4.2.2. Composite Water Sampler Flow Diagram 


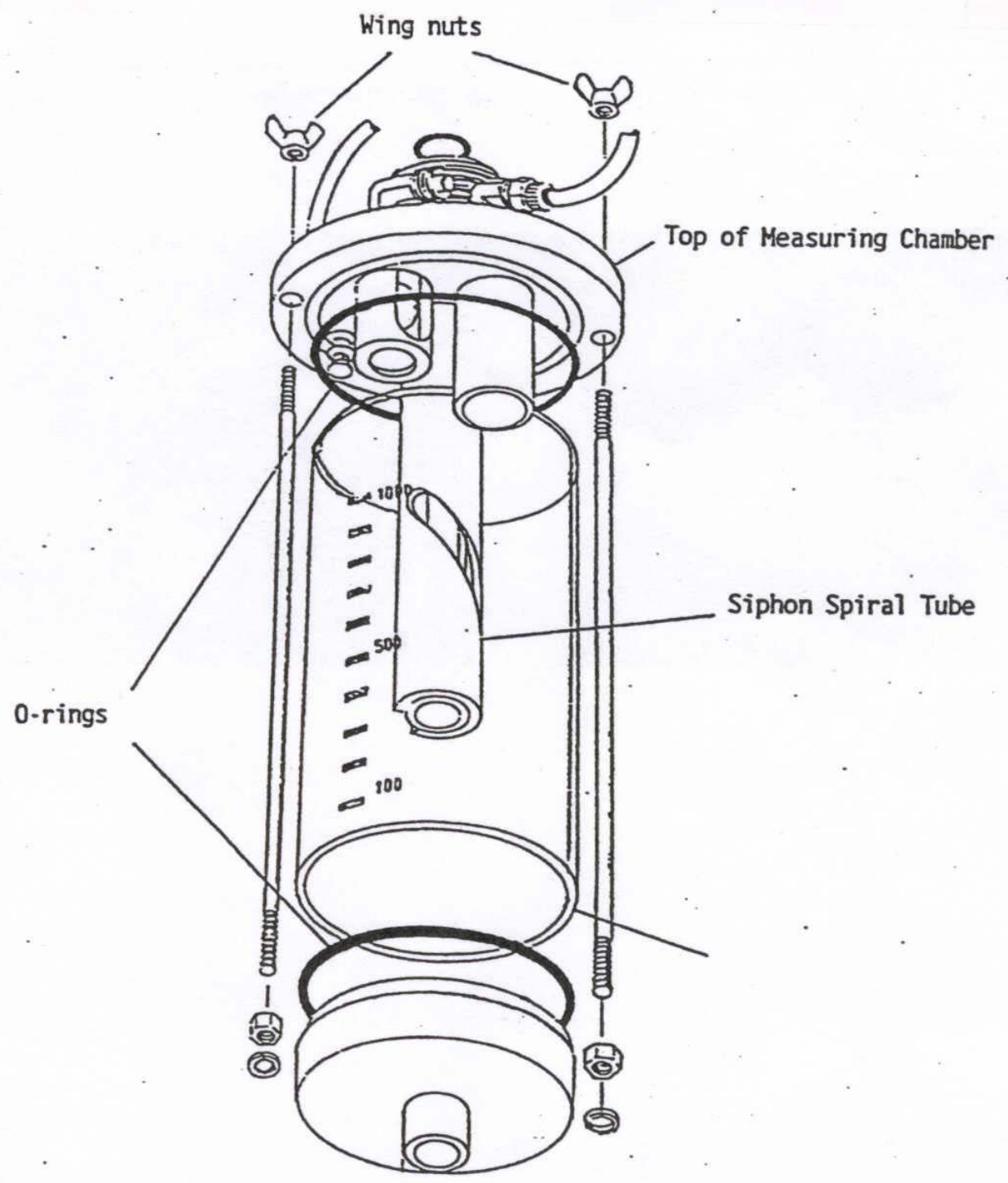

Figure 4.2.3. Measuring Chamber Detail 


\subsection{COLUMBIA RIVER CONTINUOUS WATER SAMPLES}

\begin{tabular}{|c|c|}
\hline INTRODUCTION & $\begin{array}{l}\text { Continuous water samples are the ultimate form of a composite sample. } \\
\text { Water is continuously pumped through a roughing sock filter, a Millipore } \\
\text { glass fiber filter, and a mixed-bed ion-exchange column. SESP personnel } \\
\text { refer to the continuous water sample as a filter/resin sample. The } \\
\text { filter/resin system preconcentrates a large volume of water, making it } \\
\text { possible to detect radionuclides that are present in the water in very low } \\
\text { concentrations. } \\
\text { Automatic continuous (filter/resin) water sampling systems are used at } \\
\text { permanent monitoring stations located at Priest Rapids Dam (operated by } \\
\text { Grant County PUD) and the Richland pump house (operated by the city } \\
\text { of Richland). } \\
\text { NOTE: Gate keys are needed at both locations to gain access to the } \\
\text { samplers. All PUD or city of Richland postings and requirements must be } \\
\text { followed at these two locations. } \\
\text { Figure } 4.3 .1 \text { shows a flow diagram summarizing the continuous water } \\
\text { sampling procedure. }\end{array}$ \\
\hline PERSONNEL & $\begin{array}{l}\text { Field sampling must be conducted by personnel who have received } \\
\text { training on these sampling procedures and are familiar with the sampling } \\
\text { equipment. } \\
\text { It is estimated that this procedure requires one (1) person for efficient } \\
\text { operation. }\end{array}$ \\
\hline $\begin{array}{l}\text { EQUIPMENT AND } \\
\text { SUPPLIES }\end{array}$ & $\begin{array}{l}\text { The following equipment and supplies may be needed for the collection } \\
\text { of continuous water samples: } \\
\text { - A clean resin column (U.S. Filter ionxchanger }{ }^{\mathrm{TM}} \text { research model II, } \\
\text { Lowell, MA). } \\
\text { - A clean Millipore glass fiber filter (Millipore Corp., Bedford, MA, } \\
\text { pre-filter AP20, } 293 \mathrm{~mm}[11.5 \text { in.] in diameter). }\end{array}$ \\
\hline
\end{tabular}

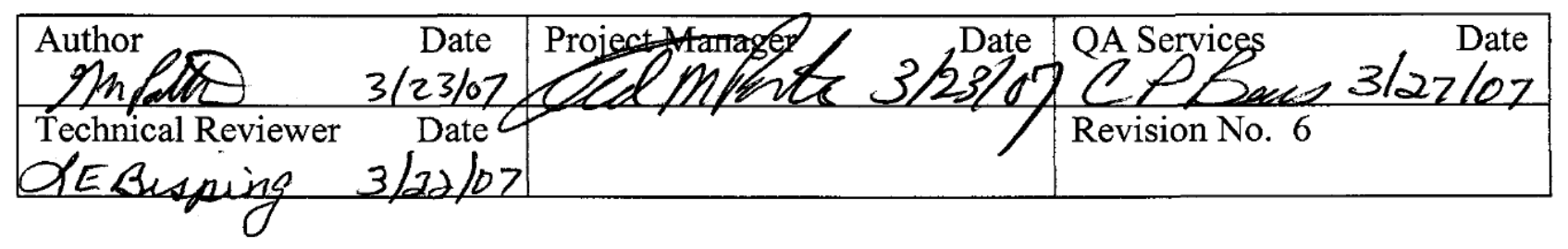




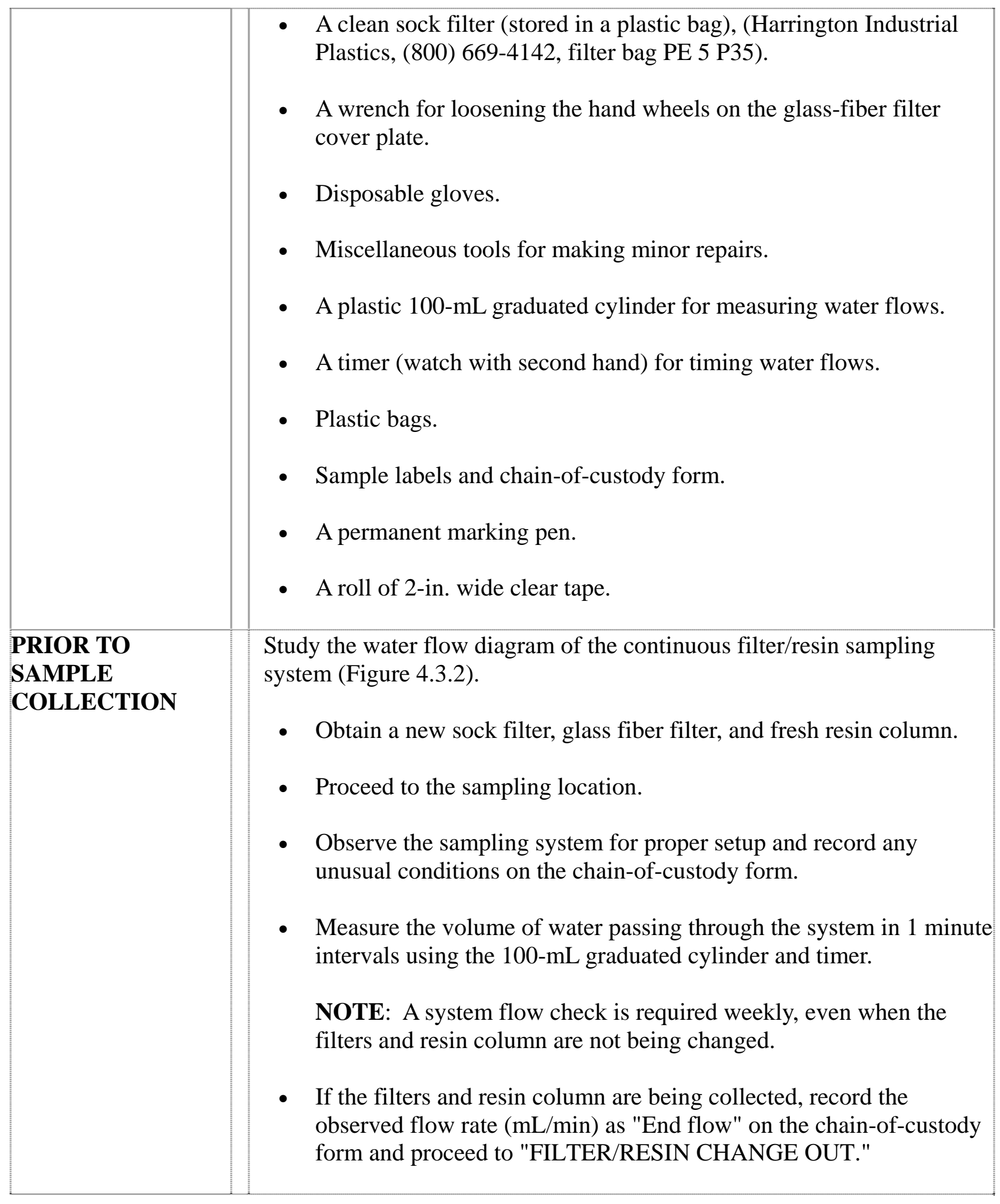




\begin{tabular}{|c|c|}
\hline & $\begin{array}{l}\text { - If the filter and resin columns are NOT being collected, record the } \\
\text { observed flow rate (mL/min) in the comment column on the } \\
\text { composite-sample chain-of-custody form. Contact the SESP surface } \\
\text { water task leader or sample collection task leader if the observed } \\
\text { flow rate is less than } 40 \mathrm{~mL} / \mathrm{min} \text {. } \\
\text { NOTE: If the filters and resin column are not being collected, use a } \\
\text { hand pump or siphon hose (stored at the sampling site) to clear the } \\
\text { sediment from the sample reservoir. Doing this on a regular basis } \\
\text { will help control algae growth and sediment accumulation. }\end{array}$ \\
\hline $\begin{array}{l}\text { FILTER/RESIN } \\
\text { CHANGE-OUT }\end{array}$ & $\begin{array}{l}\text { The procedure for collecting continuous filter/resin samples is as } \\
\text { follows: } \\
\text { - Turn the pump off with the switch on the back of the pump or by } \\
\text { unplugging the power cord. } \\
\text { - Record sample time off (i.e., the time at which power to the pump is } \\
\text { turned off) on the chain-of-custody form. } \\
\text { - Open the pressure valve to relieve the pressure on the system. } \\
\text { - Remove the locking clamp on the sock filter holder so that the sock } \\
\text { filter can be changed. } \\
\text { - Put on a clean pair of disposable gloves. } \\
\text { - Remove the sock filter, being careful not to lose any of the collected } \\
\text { material. Place the sock filter directly into a clean plastic bag. } \\
\text { - } \\
\text { - } \text { Rote: Do not lay the filter down on an unsanitary surface. } \\
\text { handwheels. } \\
\text { filtered material. } \\
\text { aside to drain. } \\
\text { yellowish nearly to the top. Note on the chain-of-custody form if the } \\
\text { column is solid yellow or solid purple. } \\
\text { - }\end{array}$ \\
\hline
\end{tabular}


- Fold the filter carefully into quarters keeping the filtered material on the inside of the fold.

- $\quad$ Place the folded filter directly into the clean plastic bag with the sock filter.

NOTE: Do not lay the filter down on an unsanitary surface.

- $\quad$ Close and tape the mouth of the plastic bag.

- Use the water hose from the sample reservoir to clean the filter holder plates and O-rings of any foreign materials. Gentle fingertip pressure with a gloved hand is usually sufficient to clean the plates and O-rings.

NOTE: The plates are Teflon coated and should not be scratched during cleaning.

- $\quad$ Place a new filter into the filter holder, waffle side down.

- Align the glass fiber filter cover plate with the lower block assembly, using the alignment stud openings. Lower the glass fiber filter cover plate carefully.

- $\quad$ Reassemble the filter holder, tightening the opposing handwheels in pairs to obtain a uniform seal.

- Insert the new sock filter into the filter holder. Filters must be turned inside out to seal properly.

- Fold the top of the sock filter over the rim of the filter holder and reset the O-ring on the filter holder to assure a complete seal.

- $\quad$ Remove the rubber end-caps from the new resin column and install them on the old column.

- Install the new resin column in the mounting brackets and verify that the O-rings are in place.

- Fill the sock filter and resin column with water from the hose supplying water to the sample reservoir.

- Replace the top of the filter holder, and tighten the locking band firmly. 


\begin{tabular}{|c|c|}
\hline & $\begin{array}{l}\text { - Turn the pump back on. } \\
\text { - } \text { Allow the system to equilibrate for } 3 \text { to } 5 \text { minutes before proceeding } \\
\text { to "SYSTEM FLOW CALIBRATION." } \\
\text { - Enter all pertinent sampling information on the chain-of-custody form } \\
\text { and sample label. } \\
\text { - Verify that the sample number and sampling date on the chain-of- } \\
\text { custody form match the sample number and sampling date on the } \\
\text { sample label. } \\
\text { - Attach the sample label to the outside of the resin column itself (not } \\
\text { to the resin column box). } \\
\text { - Cover the sample label with a strip of the 2-in. wide clear tape to } \\
\text { protect it from water and to keep it attached to the column. } \\
\text { - Place the resin column into the box that came with the new resin } \\
\text { column. } \\
\text { - Attach the sample label for the filters to the outside of the plastic bag. } \\
\text { Place the sealed plastic bag with filters into another clear plastic bag, } \\
\text { and close and tape the mouth of the outer bag. }\end{array}$ \\
\hline $\begin{array}{l}\text { SYSTEM } \\
\text { FLOW } \\
\text { CALIBRATION }\end{array}$ & $\begin{array}{l}\text { The procedure for performing a system flow calibration is as follows: } \\
\text { - Measure and record the volume of water passing through the system } \\
\text { in } 1 \text { minute intervals using the } 100-\mathrm{mL} \text { graduated cylinder and timer. } \\
\text { The proper flow rate is between } 45 \text { and } 60 \mathrm{~mL} / \mathrm{min} \text {; ideally, } \\
50 \mathrm{~mL} / \mathrm{min} \text {. } \\
\text { - If the flow rate is } 45 \text { to } 60 \mathrm{~mL} / \mathrm{min} \text {, record the flow rate as "next } \\
\text { flow" on the chain-of-custody form and proceed to the next step. } \\
\text { - If the flow rate is less than } 45 \mathrm{~mL} / \mathrm{min} \text { or greater than } 60 \mathrm{~mL} / \mathrm{min} \text {, } \\
\text { adjust the pump flow until the flow is in the proper range. } \\
\text { - Decrease the flow by moving the pump arm towards the center } \\
\text { position. } \\
\text { - Increase the flow by moving the pump arm away from the center } \\
\text { position. }\end{array}$ \\
\hline
\end{tabular}




\begin{tabular}{|c|c|}
\hline & $\begin{array}{l}\text { - Repeat the calibration steps to verify that the flow is in the proper } \\
\text { range. Continue adjusting the position of the pump arm until the } \\
\text { flow is in the proper range. } \\
\text { - Check to see that the water supply to the sample reservoir is } \\
\text { adequate but not excessive. A small stream of water is adequate. } \\
\text { The built-in overflow cannot handle an excessive flow. }\end{array}$ \\
\hline \begin{tabular}{|l|} 
CHAIN-OF- \\
CUSTODY FORM \\
AND SAMPLE \\
SUBMISSION \\
REQUIREMENTS
\end{tabular} & $\begin{array}{l}\text { See Section 8.1, Chain-of-Custody Forms, for further requirements for } \\
\text { completing chain-of-custody forms and submitting samples to an } \\
\text { analytical laboratory. }\end{array}$ \\
\hline
\end{tabular}




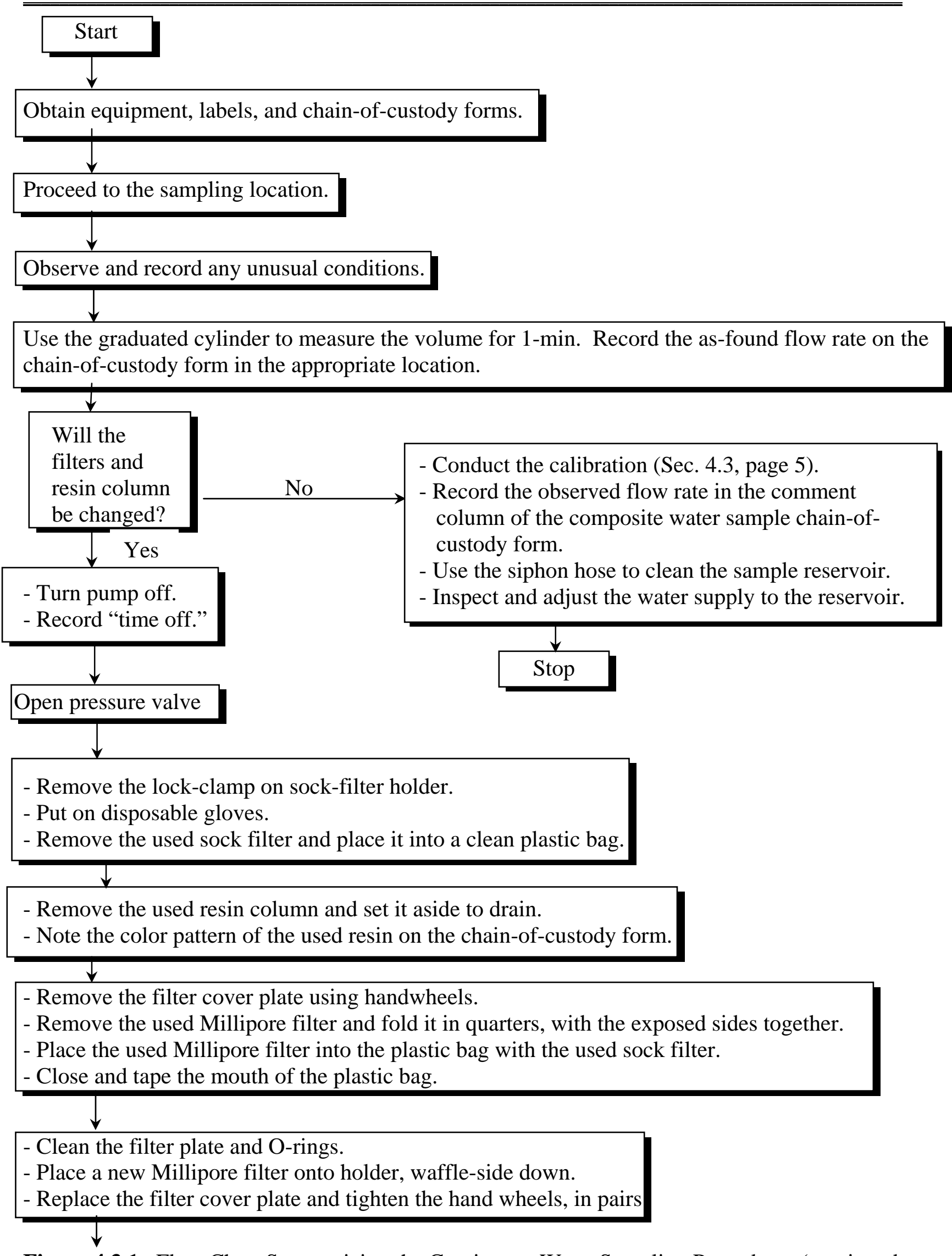

Figure 4.3.1. Flow Chart Summarizing the Continuous Water Sampling Procedures (continued on next page) 
- Insert the new sock filter (turn sock inside out).

- Fold the top of sock over the rim of the filter holder, and reset O-ring.

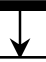

- Remove the rubber end-caps from the new resin column

- Install the new resin column and check the O-rings.

- Place rubber end-caps on the used resin column.

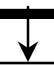

- Fill the sock filter with water from the reservoir supply hose.

- Replace the top of sock holder and tighten the band.

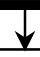

Turn the pump back on.

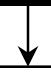

Let the system equilibrate 3-5 min.

Record all pertinent sampling information on the chain-of-custody form and sample label.<smiles>[CH]1CCC1</smiles>

- Attach the sample label to resin column and cover the label with clear tape.

- Place the used resin column into the empty resin column box.

- Attach the sample label to outside of bag containing the used filters.

- Place the filter bag into another bag and seal the outer bag.<smiles></smiles>

- Perform the system calibration.

- Measure the flow for 1-min. using the graduated cylinder.

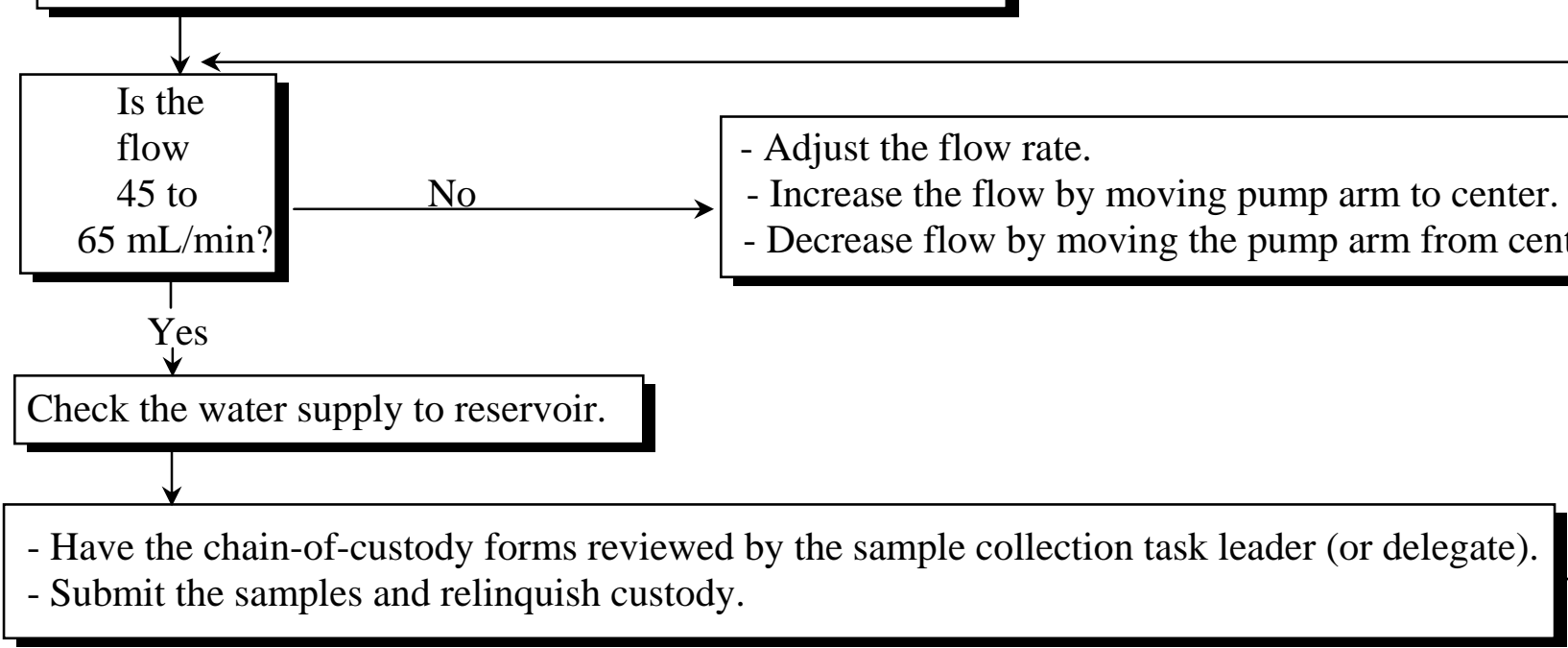

Figure 4.3.1. Flow Chart Summarizing the Continuous Water Sampling Procedures (contd) 


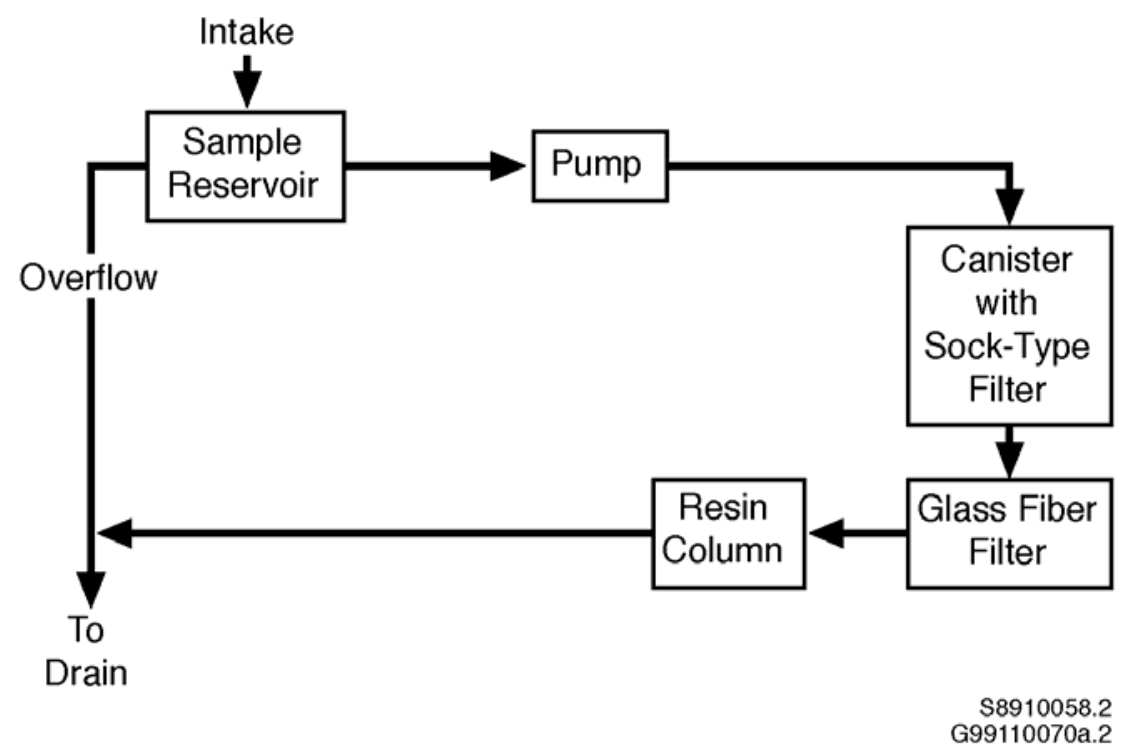

Figure 4.3.2. Continuous (Filter/Resin) Water Sampling System 


\subsection{TRANSECT AND NEAR-SHORE WATER SAMPLES}

\begin{tabular}{|c|c|}
\hline INTRODUCTION & $\begin{array}{l}\text { Chemical and radiological contaminants from the Hanford Site are } \\
\text { known to enter the Columbia River along the Hanford Reach. Water } \\
\text { samples are collected along transects and near the shoreline of the } \\
\text { Columbia River at locations upstream, downstream, and adjacent to the } \\
\text { Hanford Site. Samples are analyzed to identify the concentrations and } \\
\text { distributions of contaminants attributable to the Hanford Site. }\end{array}$ \\
\hline PERSONNEL & $\begin{array}{l}\text { The SESP surface water task leader (or designee) may oversee and } \\
\text { participate in the field sampling operations, depending on schedules and } \\
\text { circumstances. } \\
\text { Field sampling must be conducted by personnel who have received } \\
\text { appropriate training on these sampling procedures and are familiar with } \\
\text { the sampling equipment. }\end{array}$ \\
\hline $\begin{array}{l}\text { EQUIPMENT AND } \\
\text { SUPPLIES }\end{array}$ & $\begin{array}{l}\text { The following equipment and supplies may be needed in the boat for } \\
\text { the collection of Columbia River transect and near-shore water samples: } \\
\text { - Fast water (flat) anchor with at least } 150 \text { feet of heavy duty anchor } \\
\text { rope. } \\
\text { - Davit with winch and steel cable (see Figure 4.4.1). } \\
\text { - Wire line depressor (see Figure } 4.4 .1 \text { ) with screw-pin shackle. } \\
\text { - A } 0.25 \text {-in. diameter rope (75-feet) for tethering the wire line } \\
\text { depressor. } \\
\text { A stainless-steel water sampling table with drain hose (samples } \\
\text { can be collected without this). } \\
\text { A ring stand with one 3-finger clamp. } \\
\text { A roll of water-resistant green tape for securing plastic tubing to } \\
\text { the winch cable. } \\
\text { A depth finder. }\end{array}$ \\
\hline
\end{tabular}

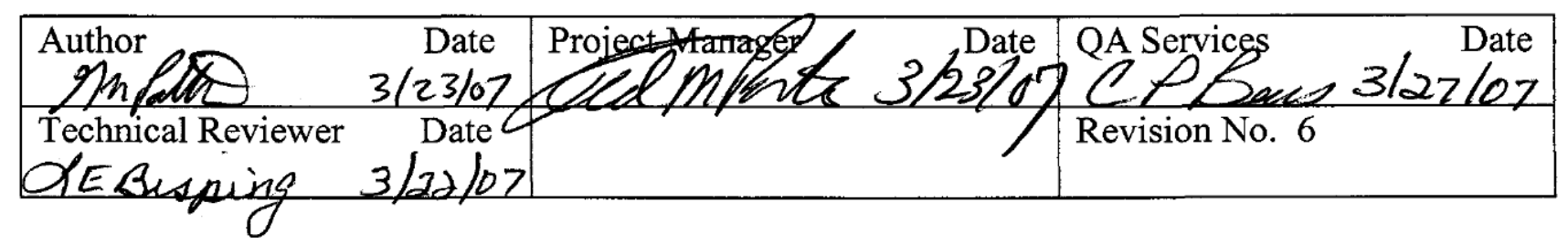




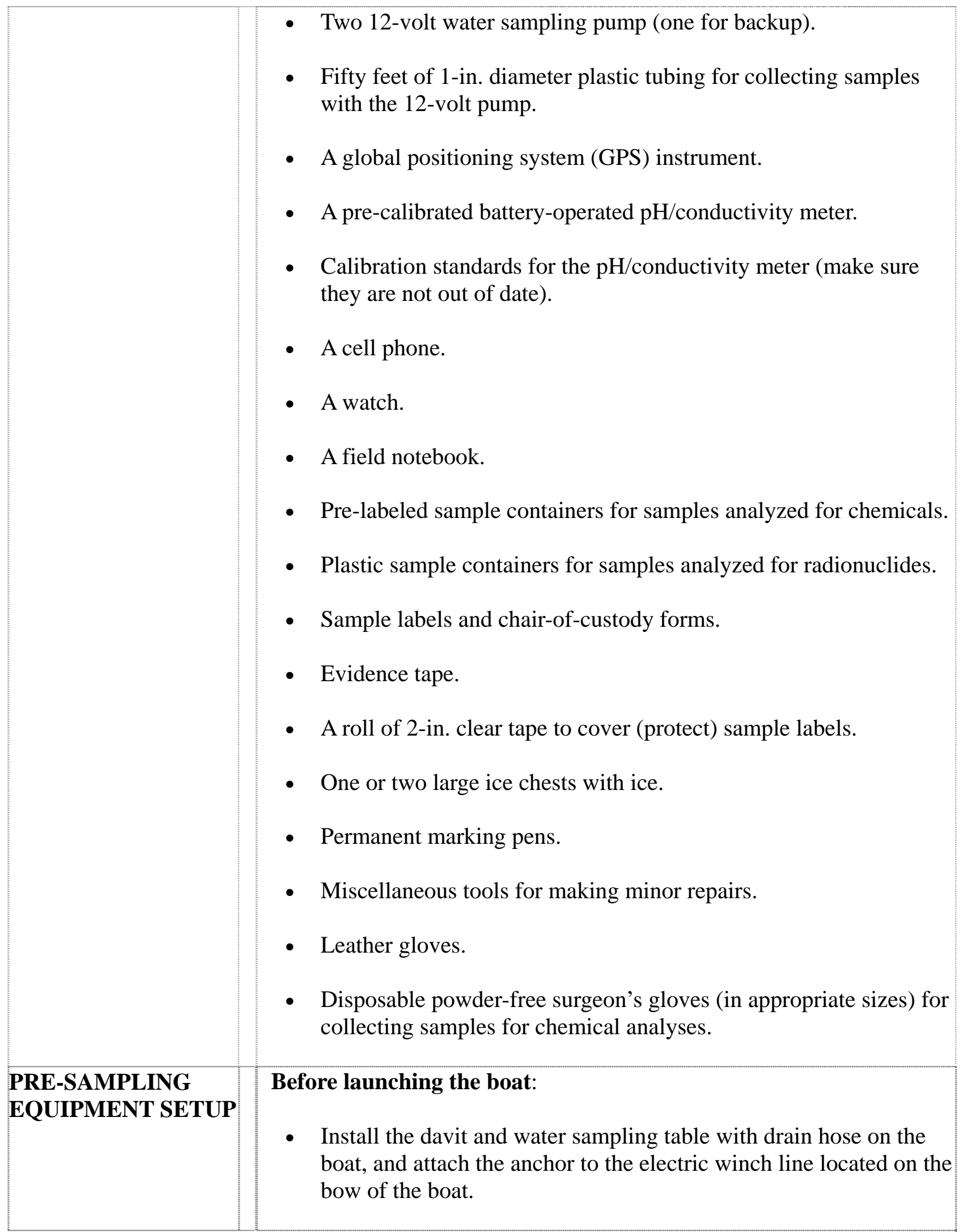




\begin{tabular}{|c|c|}
\hline & $\begin{array}{l}\text { - Secure the anchor to the boat so that it will not move or fall off } \\
\text { when the boat is being towed. To help prevent back injury, the } \\
\text { installation of the davit should be accomplished by at least three, } \\
\text { individuals. } \\
\text { - Test the winch and sampling pump to verify that they are working } \\
\text { properly. }\end{array}$ \\
\hline $\begin{array}{l}\text { ESTABLISHING } \\
\text { AND } \\
\text { DOCUMENTING } \\
\text { SAMPLING } \\
\text { LOCATIONS }\end{array}$ & $\begin{array}{l}\text { The procedures for identifying, establishing, and documenting a } \\
\text { sampling location are as follows: } \\
\text { - Select the sampling or transect-line locations using experience } \\
\text { from past transect sampling activities, landmarks on or near the } \\
\text { river that are identified in the SESP sampling locations manual or } \\
\text { field notebook, or previously acquired GPS coordinates. } \\
\text { - If conditions at the selected site are inappropriate for collection } \\
\text { (e.g., too shallow or weedy), move to the closest appropriate } \\
\text { location on the transect line. } \\
\text { - Record any landmarks used for establishing the sampling location } \\
\text { or transect line, and any location coordinate readings, on the chain- } \\
\text { of-custody form or in a field notebook. Use a GPS instrument to } \\
\text { determine the final location coordinates (see Section 8.5). Record } \\
\text { the final coordinates on the chain-of-custody form. }\end{array}$ \\
\hline $\begin{array}{l}\text { ANCHORING THE } \\
\text { BOAT }\end{array}$ & $\begin{array}{l}\text { The procedures for anchoring the boat are as follows: } \\
\text { - Drop the anchor several boat lengths upstream of the actual } \\
\text { sampling location. The river current may drag the boat } \\
\text { downstream of the selected sampling location before the anchor } \\
\text { can snag the bottom. Depending on circumstances, several } \\
\text { anchoring attempts may be necessary before the anchor snags the } \\
\text { bottom. } \\
\text { - If anchoring is not possible, samples should not be collected unless } \\
\text { permission to do so is granted by the surface water task leader. } \\
\text { Once anchored, shut off the boat motor. } \\
\text { CAUTION: Prior to dropping the anchor, secure, or tie a knot at } \\
\text { the loose end of the anchor rope. This will prevent the winch from } \\
\text { feeding out all of the anchor line. }\end{array}$ \\
\hline
\end{tabular}




\begin{tabular}{|c|c|}
\hline & $\begin{array}{l}\text { CAUTION: Do not allow excess slack in the anchor rope during } \\
\text { anchoring. The slack rope may be sucked into the jet boat intake. } \\
\text { Do not allow the anchor line to float under the boat. }\end{array}$ \\
\hline $\begin{array}{l}\text { SETTING UP } \\
\text { SAMPLING } \\
\text { EQUIPMENT }\end{array}$ & $\begin{array}{l}\text { The procedures for setting up the sampling equipment are as } \\
\text { follows: } \\
\text { - Connect the wire-line depressor to the end of the winch cable } \\
\text { using a screw-pin anchor shackle. } \\
\text { NOTE: If sampling in a current, it may be appropriate to tie a } \\
\text { tether line (0.25-in. rope) to the shackle holding the depressor, and } \\
\text { run the line along the exterior of the boat cabin to a cleat on the } \\
\text { bow of the boat (see Figure } 4.4 .1 \text { ). This tether line will be lowered } \\
\text { with the cable and depressor and will be used to keep the cable in a } \\
\text { vertical position in the current. In some circumstances, if a tether } \\
\text { is not used, the depressor (and sampling line) can be pushed } \\
\text { downstream at an angle, resulting in an inaccurate sampling depth. } \\
\text { Ideally, the cable should be kept vertical when sampling to assure } \\
\text { an accurate sampling depth. } \\
\text { - Attach the plastic tubing to both the intake and discharge ports of } \\
\text { the sampling pump } \\
\text { - } \\
\text { - Tape (using water-resistant green tape) the intake end of the tubing } \\
\text { the need to handle the hose during sample collection). } \\
\text { the winch cable so that the end of the tubing is } 6 \text { in. or so above } \\
\text { the shackle holding the wire-line depressor. } \\
\text { Tape the tubing to the cable (with strips of water-resistant green } \\
\text { tape) every } 1 \text { to } 1.5 \text { feet for the first } 6 \text { feet so the tubing does not } \\
\text { slide up on the cable as the depressor and tubing are lowered into } \\
\text { the river. } \\
\text { should be draped over the side of the boat so that the discharge } \\
\text { water does not enter the boat). } \\
\text { - } \\
\text { - }\end{array}$ \\
\hline
\end{tabular}




\section{SAMPLE COLLECTION}

\section{The procedures for collecting samples are as follows:}

- Begin sampling at the location closest to the Franklin or Grant County shoreline. Collect the samples near the Hanford Site shoreline last.

NOTE: Remember that the Hanford Site shore is station \#1 and the Franklin or Grant County shore has the highest station number (e.g., station \#10 at the Richland pump house and station \#4 at the Vernita Bridge).

- Lower the water sampling intake assembly to the appropriate water depth. A yardstick taped to the davit provides a convenient way to measure the cable as it is spooled out of the winch.

NOTE: The appropriate depth is approximately one-half of the water depth as measured with the boat's depth finder.

- Use the tether line, if necessary, to maintain the winch cable in a vertical position (See Figure 4.4.1).

- Start the sampling pump. Run the pump for 5-10 minutes at the first station of each transect to purge the sampling line. After the first station, the purge time can be reduced to 2-3 minutes between stations.

NOTE: Do not turn off the pump until all the samples at a specific location are collected.

- Measure the conductivity and $\mathrm{pH}$ of the water (from the water stream at the water table) (see Sections 4.6 and 4.7), and record the readings on the chain-of-custody form.

- Enter all pertinent sampling information on the chain-of-custody form and sample label.

- $\quad$ Dry off the container.

- If not already done, attach the sample label to the 10 -L sample container.

- Cover the sample label on the 10-L sample container with a strip of the 2-in. wide clear plastic tape to protect it from water and keep it affixed to the container. 


\begin{tabular}{|c|c|}
\hline & $\begin{array}{l}\text { - Put on surgeon's gloves if collecting samples for chemical } \\
\text { analyses. } \\
\text { - Collect the samples from the water stream of the pump. } \\
\text { NOTE: If filtered water samples are required, see Section 4.8. A } \\
\text { sample requiring filtration is identified on the chain-of-custody } \\
\text { form and/or sample label. } \\
\text { - Cap the sample container tightly and seal the cap with evidence } \\
\text { tape. } \\
\text { Put all chemical sample containers in large plastic bags (if } \\
\text { supplied with the sample containers), and place the sealed bags on } \\
\text { ice in an ice chest. If bags are not supplied, put the individual } \\
\text { containers on ice in the ice chest. } \\
\text { Raise the wire-line depressor and the anchor, secure all of the } \\
\text { equipment on the water table, proceed to the next sampling station, } \\
\text { and repeat the sampling procedures outlined above. } \\
\text { - After sampling, verify that the sample number and sampling date } \\
\text { on the chain-of-custody form match the sample number and } \\
\text { sampling date on the sample label. }\end{array}$ \\
\hline $\begin{array}{l}\text { CHAIN-OF- } \\
\text { CUSTODY FORMS } \\
\text { AND SAMPLE } \\
\text { SUBMISSION } \\
\text { REQUIREMENTS }\end{array}$ & $\begin{array}{l}\text { See Section 8.1, Chain-of-Custody Forms, for further requirements for } \\
\text { completing chain-of-custody forms and submitting samples to an } \\
\text { analytical laboratory. }\end{array}$ \\
\hline
\end{tabular}


Section 4.4

Issued: 03-07

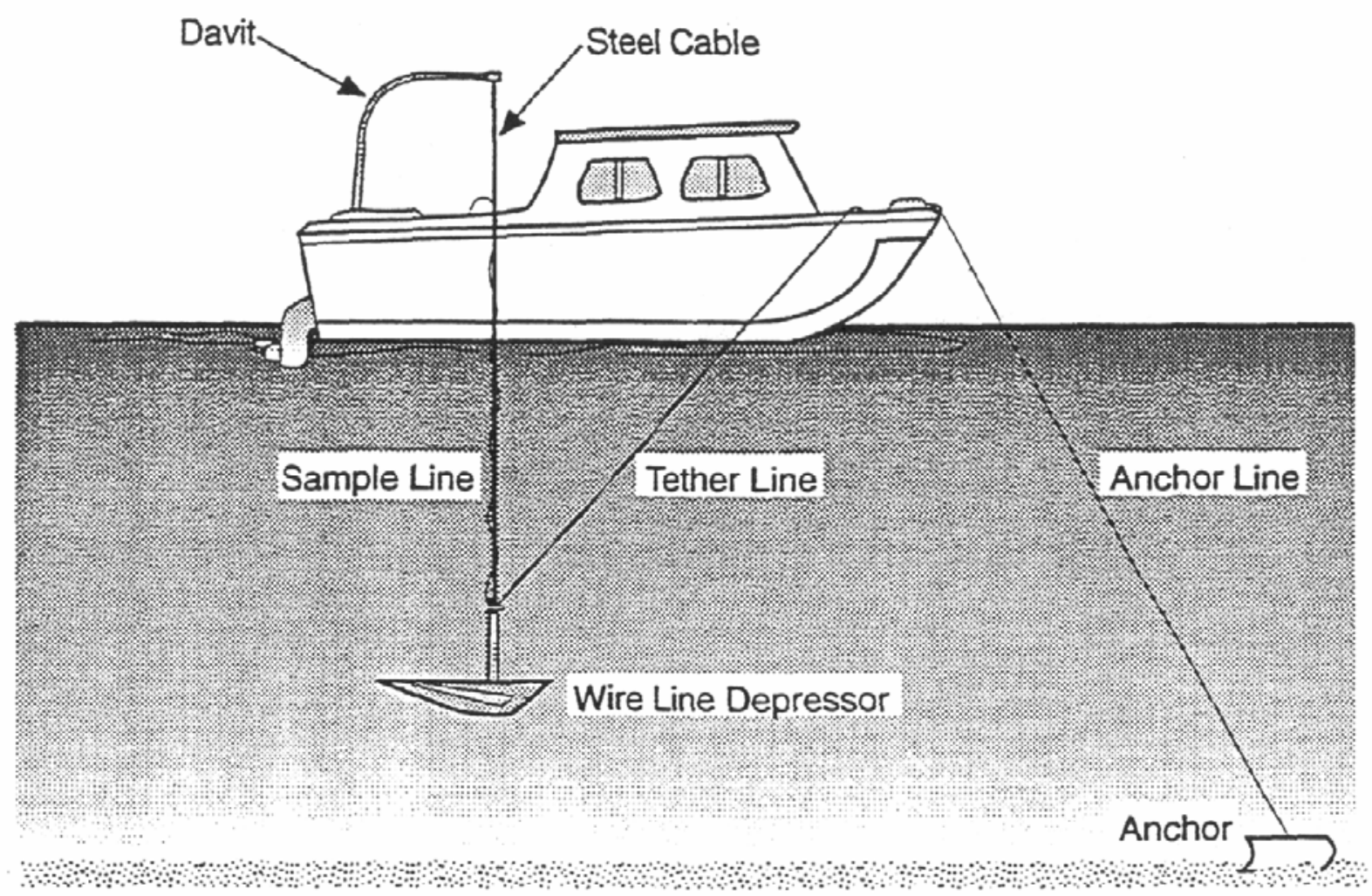

S9504050.1

Figure 4.4.1. Sample Vessel and Equipment 


\subsection{RIVERBANK SPRING WATER AND SEDIMENT}

\begin{tabular}{|c|c|}
\hline INTRODUCTION & $\begin{array}{l}\text { The SESP collects water and sediment samples from selected Hanford } \\
\text { riverbank spring locations to monitor the types and amounts of } \\
\text { contaminants entering the river and to define the extent of contamination } \\
\text { along the river shoreline. } \\
\text { Generally, Columbia River shoreline springs are only accessible when river } \\
\text { flows are low and shoreline "beach" areas are exposed. River flows in the } \\
\text { Hanford Reach of the Columbia River fluctuate daily as a result of changes } \\
\text { in discharge volume at Priest Rapids Dam. River flows are usually lower } \\
\text { from Saturday through Monday or Tuesday. }\end{array}$ \\
\hline PERSONNEL & $\begin{array}{l}\text { Field sampling must be conducted by personnel who have received } \\
\text { appropriate training on these sampling procedures and are technically } \\
\text { knowledgeable in the use of the sampling equipment. }\end{array}$ \\
\hline $\begin{array}{l}\text { EQUIPMENT AND } \\
\text { SUPPLIES }\end{array}$ & $\begin{array}{l}\text { The following equipment and supplies may be needed for the collection of } \\
\text { Columbia River riverbank spring water and sediment samples: } \\
\text { - A cellular telephone. } \\
\text { - 10-L (2.5-gal) and 4-L (1-gal) plastic sample containers with lids for } \\
\text { radiological water samples, as needed. } \\
\text { - Pre-labeled containers for samples analyzed for chemical. } \\
\text { - At least one large plastic spoon. } \\
\text { - A small volume, hand-operated plastic siphon-pump for collecting } \\
\text { water samples. } \\
\text { A Masterflex peristaltic pump including: } \\
\text { 1) Pump housing. } \\
\text { 2) Easy-load pump head. } \\
\text { 3) AC and DC power cords. } \\
\text { 4) Spare fuses (0.25 amp and } 2.5 \text { amp). }\end{array}$ \\
\hline
\end{tabular}

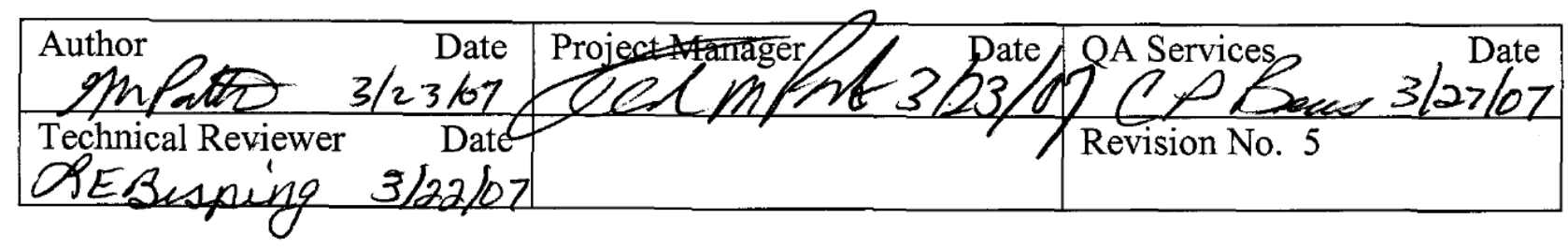




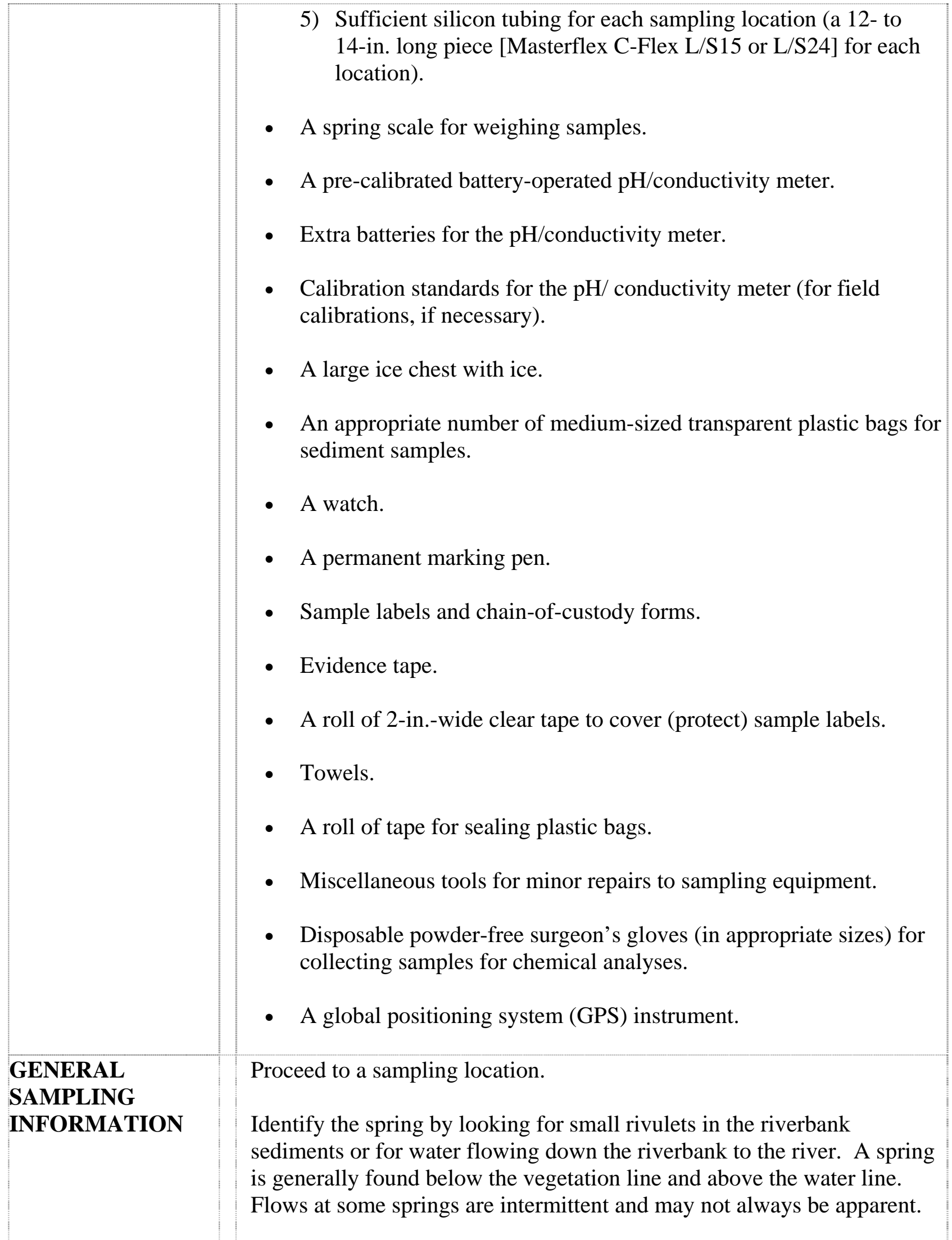


Water flowing from a riverbank spring is a mixture of Hanford Site groundwater and Columbia River water that has infiltrated the riverbank (bank storage). The conductivity of groundwater (typically $>400 \mu \mathrm{S} / \mathrm{cm}$ ) is higher than the conductivity of river water (typically $~ 130$ to $140 \mu \mathrm{S} / \mathrm{cm})$. Thus, field conductivity measurements can be used to estimate the fractional amount of groundwater in water from a riverbank spring.

NOTE: A spring can be approached by boat or four-wheel drive vehicle. In some cases, it is more practical to approach the sampling site by boat to avoid entering restricted or controlled areas, carrying equipment and samples for long distances on foot, and unnecessary off-road activity in sensitive wildlife areas. Access routes should be discussed with the surface water task leader or sample collection task leader prior to sampling.

\section{Riverbank samples are collected in the following order:}

- Water samples for chemical analyses are collected first.

- Water samples for radiological analyses are collected second.

- Sediment samples are collected after all water samples have been collected.

\section{Upon arrival at the spring:}

- Measure the conductivity of the spring water (see Section 4.6) and record the measurement in the comments portion of the chain-ofcustody form as the initial conductivity.

NOTE: This measurement will be used by the field team to determine what fraction of the flowing stream is groundwater. Ideally, a conductivity measurement above the normal river conductivity level is desired (more groundwater than river water in the flow). For most locations a measurement $>180 \mu \mathrm{S} / \mathrm{cm}$ is high enough to initiate sampling. At a spring with a low or marginal conductivity measurement, the field team will have to decide whether to collect a sample or wait and try again at a later time. To make this decision, the low conductivity measurement may have to be balanced with other factors such as the number of samples being collected that day, available daylight, future access to the spring because of river stage changes, future availability of sampling staff and equipment. The SESP surface water task leader should be contacted when the field team has questions about the collection of a sample. 
- At each sampling location, prior to collecting a sample, clean the pump by pumping several liters of spring water through it. Care should be taken to collect water that is clean and free of sediment and debris. It may be necessary to pump slowly to avoid disturbing any sediment near the pump intake port.

- Put on clean surgeon's gloves if collecting samples for chemical analyses.

- $\quad$ Pump or dip water from the spring into the sample containers. Either the hand pump or peristaltic pump can be used (see Section 4.8 for peristaltic pump operating procedures).

NOTE: If the spring is shallow or flow is low, sample collection can be facilitated by using the plastic spoon to dig a small basin in the rocks and sediment, and allowing the spring water to accumulate. Once the basin is full and the water is free of all disturbed sediments, water can be pumped or spooned from the basin to the sample container. A thin, flat rock placed at the bottom of the basin, underneath the intake port of the pump, may help prevent resuspension of sediments while the pump is being operated.

- $\quad$ Fill the containers to the neck.

- If a filtered water sample is needed, see Section 4.8 for instructions on collecting filtered water samples. Samples requiring filtration will be identified on the chain-of-custody form and/or sample label.

- If not already done, attach the sample label to the sample container.

- Cover the sample label on the sample container with a strip of 2-in. wide clear plastic tape to protect it from water and keep it attached to the container.

- Re-measure the conductivity of the spring water. If the measurement is similar to the initial measurement, record this measurement as the conductivity of the sample. If the second measurement differs from the initial measurement, measure the conductivity of the water in the sample container (if no preservatives have been added to the container) and record this as the conductivity of the sample.

- $\quad$ Measure the $\mathrm{pH}$ of the water in the spring (see Section 4.7) and record this measurement on the chain-of-custody form. 
- Cap the sample container and seal the cap with evidence tape.

- Put all chemical sample containers on ice in the ice chest.

- Use the GPS instrument to determine the coordinates of the sampling location. Record the coordinates on the chain-of-custody form.

- Enter all pertinent sampling information on the chain-of-custody form and sample label.

- Verify that the sample number and sampling date on the chain-ofcustody form match the sample number and sampling date on the sample label.

COLLECTING SEDIMENT SAMPLES
Sediment samples are collected at selected springs after the water samples have been collected. Sediments are analyzed for chemicals and radionuclides. Enough sediment is collected to fill a medium-size plastic bag (for radiological analysis) and a small sample container (for chemical analyses).

\section{The procedures for collecting riverbank spring sediment samples are} as follows:

- Put on clean surgeon's gloves if collecting samples for chemical analyses.

- Use a large plastic spoon that has been rinsed with nearby river water.

- Collect sediments from the vicinity of where the springs first discharge from the riverbank and place the sample into a clean plastic bag. Avoid the inclusion of rocks in the sample.

- Weigh the samples and continue to add sediment until an adequate amount has been collected. The required sample mass is indicated on the sample chain-of-custody form.

- Mix the sediment in the bag thoroughly with the plastic spoon before subsampling for the chemical analysis samples.

- Verify that the container for the chemical analysis sub-sample is the correct one for the location. 


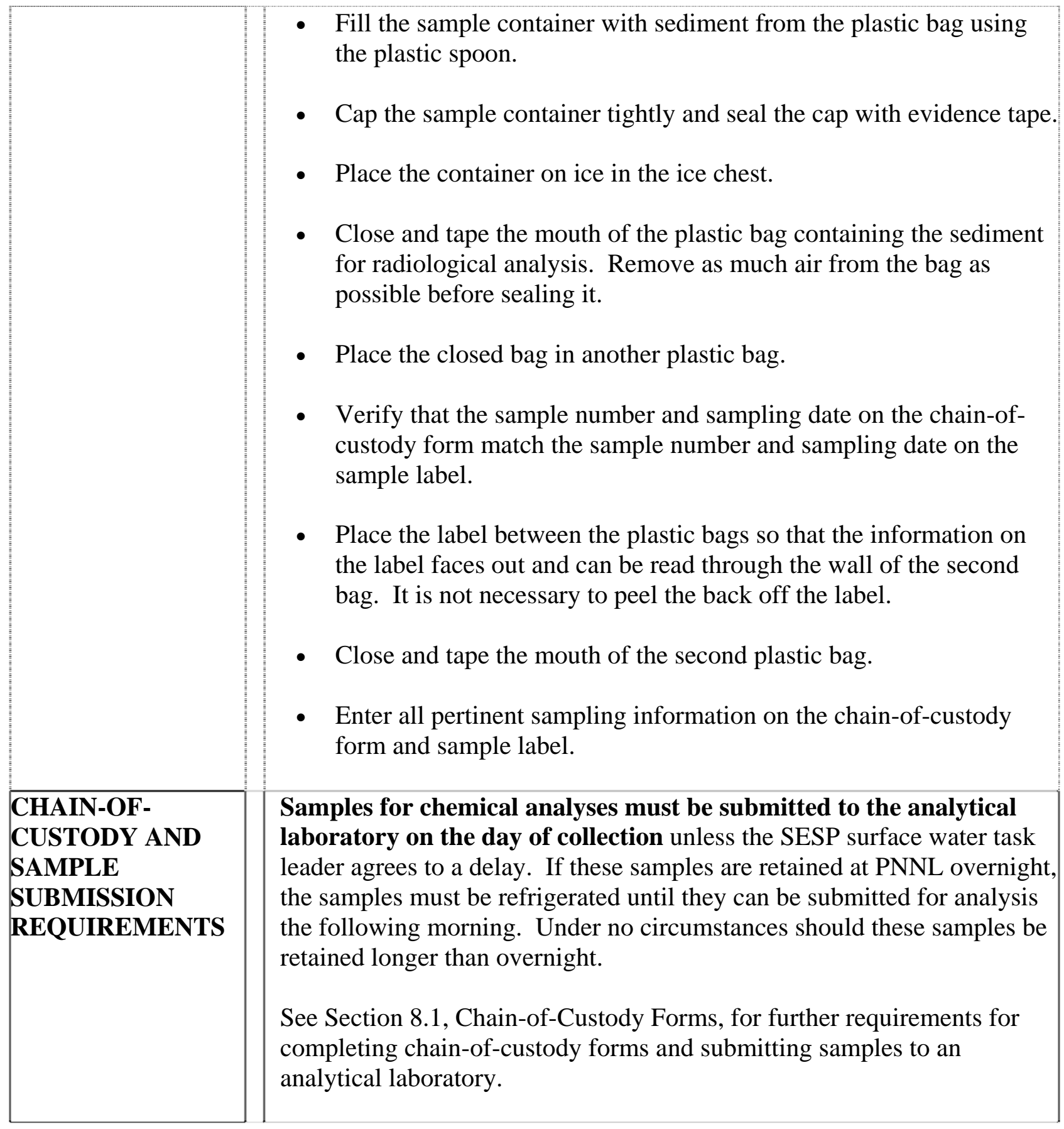




\subsection{CONDUCTIVITY MEASUREMENT}

INTRODUCTION

PERSONNEL
This procedure is for measuring conductivity during routine water sample collections.

Field sampling must be conducted by personnel who have received training on these procedures and are familiar with the sampling equipment.

It is estimated that this procedure requires one (1) person for efficient operation.

The following equipment and supplies may be needed for measuring the conductivity of surface water in the field:

- A field-portable conductivity meter with the following specifications: (accuracy $\pm 5 \%$ of full scale or better; resolution, by either digital or analog display, to $1 \%$ of full scale or less; inclusion of a dip sensor, a cup cell, or a flow-through cell; either manual or automatic temperature compensation).

NOTE: Many suitable commercially available conductivity meters exist, and the manufacturer's catalog listing of specifications is acceptable evidence that a given instrument meets the above specifications.

- A standard solution of known conductivity for conductivity meter calibration. For Hanford surface water, a standard solution having conductivity from 100 to $500 \mu \mathrm{S} / \mathrm{cm}$ is most suitable. The solution must meet the following requirements: the nominal conductance of the solution must be clearly noted on the label of the solution bottle; the temperature restrictions or requirements of the solution must be clearly noted on the label; and the tolerance must be no greater than $\pm 1 \%$ relative error.

NOTE: Commercially prepared conductance standards that meet the above requirements are acceptable, and the manufacturer's label containing lot number and expiration date is acceptable for certification of specifications.

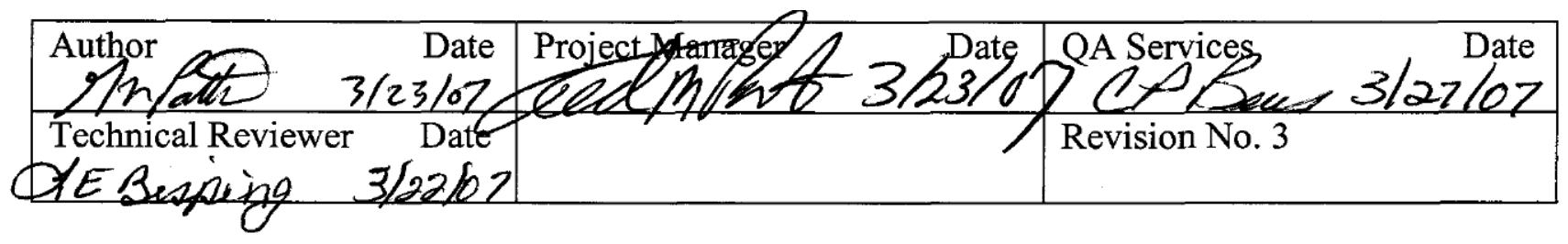




\begin{tabular}{|c|c|}
\hline & $\begin{array}{l}\text { - The manufacturer's written instructions for the instrument in use are } \\
\text { to accompany the instrument, and be considered part of this } \\
\text { procedure. } \\
\text { - A Conductivity Calibration Record Form (Figure 4.6.1). } \\
\text { - A chain-of-custody form. } \\
\text { - A spare conductivity meter in the event that the primary meter fails } \\
\text { to work properly. }\end{array}$ \\
\hline $\begin{array}{l}\text { CALIBRATING } \\
\text { THE } \\
\text { CONDUCTIVITY } \\
\text { METER }\end{array}$ & $\begin{array}{l}\text { Because there are a wide variety of commercially available conductivity } \\
\text { meters suitable for use in this procedure, it is not possible to provide } \\
\text { detailed operating instructions. In each case, follow the manufacturer's } \\
\text { instructions. It is particularly important to strictly observe the } \\
\text { manufacturer's recommendations regarding care and storage of the } \\
\text { sensing elements, battery charging (where applicable) or battery life, } \\
\text { calibrating the instrument, and conditions of use in the field. In addition } \\
\text { to the manufacturer's instructions, the following steps must be followed: } \\
\text { - Check the calibration of the conductivity meter before leaving for } \\
\text { the field and complete and sign the Conductivity Calibration Record } \\
\text { Form (Figure } 4.6 .1 \text { ) (the form remains in the office of the SESP } \\
\text { sample collector). Use the calibration solution concentration } \\
\text { recommended by the manufacturer. If the meter shows greater than } \\
\pm 5 \% \text { error with respect to the calibration solution, the meter must be } \\
\text { recalibrated. } \\
\text { NOTE: When the Conductivity Calibration Record Form is full, } \\
\text { start a new form, and give the old form to the sample collection task } \\
\text { leader. } \\
\text { After the calibration check, discard the used solution. } \\
\text { NOTE: Always replace the cap on the calibration solution bottle } \\
\text { when calibration is completed. }\end{array}$ \\
\hline $\begin{array}{l}\text { CONDUCTIVITY } \\
\text { MEASUREMENT } \\
\text { PROCEDURE }\end{array}$ & $\begin{array}{l}\text { - Thoroughly rinse the conductivity cell, or dip sensor, with the water } \\
\text { being sampled, then refill with water for the conductance } \\
\text { measurement. } \\
\text { - Record the conductance measurement on the chain-of-custody form. } \\
\text { - If the accuracy of the conductivity meter is suspect, use the spare } \\
\text { conductivity meter. }\end{array}$ \\
\hline
\end{tabular}


If the spare meter is used:

- Check its calibration status prior to use, recording the calibrationcheck information in the comment section of the chain-of-custody form and on the Conductivity Calibration Record Form.

When work is completed:

- Return the conductivity meter and calibration solution to storage. 


\begin{tabular}{|c|c|c|c|c|c|}
\hline \multicolumn{6}{|c|}{ Conductivity Calibration Record Form } \\
\hline $\begin{array}{c}\text { Conductivity } \\
\text { Meter \# }\end{array}$ & Operator & Date & $\begin{array}{c}\mu \mathrm{S} \\
\text { Standard Solution }\end{array}$ & $\begin{array}{l}\text { Exp. Date } \\
\text { Checked }\end{array}$ & $\begin{array}{c}\mu \mathrm{S} \\
\text { Calibration Value }\end{array}$ \\
\hline & & & & & \\
\hline & & & & & \\
\hline & & & & & \\
\hline & & & & & \\
\hline & & & & & \\
\hline & & & & & \\
\hline & & & & & \\
\hline & & & & & \\
\hline & & & & & \\
\hline & & & & & \\
\hline & & & & & \\
\hline & & & & & \\
\hline & & & & & \\
\hline & & & & & \\
\hline & & & & & \\
\hline & & & & & \\
\hline & & & & & \\
\hline & & & & & \\
\hline & & & & & \\
\hline & & & & & \\
\hline
\end{tabular}

Figure 4.6.1. SESP Conductivity Calibration Record Form 


\section{7 pH MEASUREMENT}

\begin{tabular}{|c|c|}
\hline INTRODUCTION & $\begin{array}{l}\text { This procedure is for measuring } \mathrm{pH} \text { during the routine collection of water } \\
\text { samples. }\end{array}$ \\
\hline PERSONNEL & $\begin{array}{l}\text { Field sampling must be conducted by personnel who have received } \\
\text { training on these procedures and are familiar with the measurement } \\
\text { equipment. } \\
\text { It is estimated that this procedure requires one (1) person for efficient } \\
\text { operation. }\end{array}$ \\
\hline $\begin{array}{l}\text { EQUIPMENT AND } \\
\text { SUPPLIES }\end{array}$ & $\begin{array}{l}\text { The following equipment and supplies may be needed for measuring } \mathrm{pH} \text {. } \\
\text { A field portable pH meter with the following specifications: } \\
\text { (accuracy } \pm 0.1 \mathrm{pH} \text { unit or better; resolution, by either digital or } \\
\text { analog display, to } 0.01 \mathrm{pH} \text { units or less; inclusion of dip electrodes, a } \\
\text { cup cell, or a flow-through cell; either manual or automatic } \\
\text { temperature compensation). } \\
\text { NOTE: Many suitable commercially available pH meters exist, and } \\
\text { the manufacturer's catalog listing of specifications is acceptable } \\
\text { evidence that a given instrument meets the above requirements. } \\
\text { - Standard buffer solutions for pH meter calibration. The SESP } \\
\text { maintains a stock of buffers with pH values of } 4 \text {, 7, and } 10 \text {. } \\
\text { NOTE: The buffers must meet the following requirements: the } \\
\text { temperature restrictions of the solution must be clearly noted on the } \\
\text { label of the solution bottle, the accuracy of the solution must be } \\
\text { clearly noted on the label of the solution bottle, and the tolerance } \\
\text { must be no greater than } \pm 0.05 \text { pH units; nominal value, lot number, } \\
\text { and expiration date must be clearly noted on the label of the solution } \\
\text { bottle, and the solutions should be color-coded. Commercially } \\
\text { prepared buffer solutions that meet the above requirements are } \\
\text { acceptable for this procedure, and the manufacturer's label is } \\
\text { acceptable as certification of specifications. } \\
\text { The manufacturer's written instructions for the instrument should } \\
\text { accompany the instrument into the field. }\end{array}$ \\
\hline
\end{tabular}

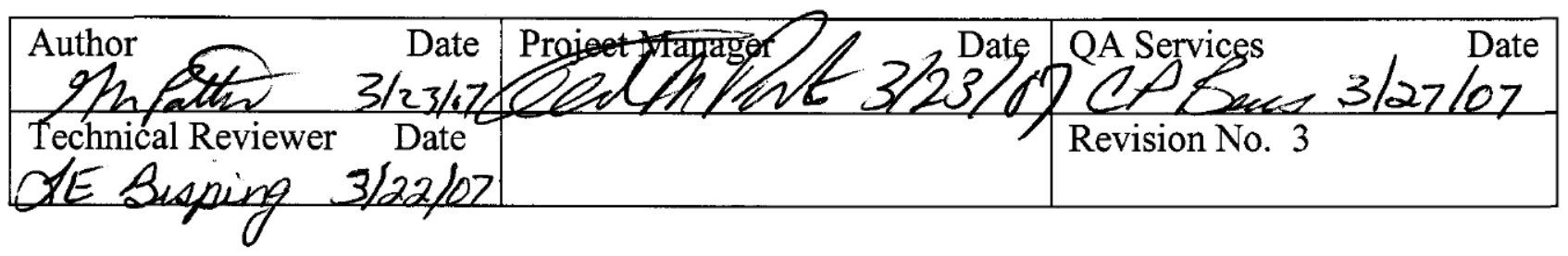




\begin{tabular}{|c|c|}
\hline & $\begin{array}{l}\text { - } \text { Chain-of-custody form. } \\
\text { - } \text { pH Meter Calibration Record Form (Figure 4.7.1). } \\
\text { properly. }\end{array}$ \\
\hline $\begin{array}{l}\text { CALIBRATING } \\
\text { THE pH METER }\end{array}$ & $\begin{array}{l}\text { Because there are a wide variety of commercially available pH meters } \\
\text { suitable for use in this procedure, it is not possible to provide detailed } \\
\text { operating instructions here. For each meter used, follow the } \\
\text { manufacturer's instructions. It is particularly important to strictly observe } \\
\text { the manufacturer's recommendations regarding care and storage of the } \\
\text { sensing electrodes, battery charging (where applicable) or battery life, } \\
\text { calibrating the instrument, and conditions of use in the field. In addition } \\
\text { to the manufacturer's instruction, the following steps must be followed: } \\
\text { - Calibrate the pH meter before leaving for the field and complete and } \\
\text { sign the pH Meter Calibration Record Form (Figure 4.7.1) (the form } \\
\text { remains in the office of the SESP sample collector). } \\
\text { NOTE: When the calibration record form is full, start a new form, } \\
\text { and give the old form to the sample collection task leader. } \\
\text { NOTE: The principal reason for the above step is to assure that the } \\
\text { meter is in operational condition. Also, if this calibration step is } \\
\text { performed using the same buffers used in the field, recalibration in } \\
\text { the field may be avoided if meter drift is within the limits described } \\
\text { below. Always replace the caps to the buffer solution bottles when } \\
\text { the calibration is complete. } \\
\text { After the instrument calibration or calibration check, discard the } \\
\text { used portion of the buffer solution. }\end{array}$ \\
\hline $\begin{array}{l}\text { pH } \\
\text { MEASUREMENT } \\
\text { PROCEDURE }\end{array}$ & $\begin{array}{l}\text { The pH measurement procedure is as follows: } \\
\text { - Thoroughly rinse the meter electrode or cell with the sample water, } \\
\text { then dip the electrode in (or fill the cell with) the sample water. } \\
\text { - Record the } \mathrm{pH} \text { (to the nearest } 0.01 \text { unit) on the chain-of-custody } \\
\text { form. } \\
\text { - If the accuracy of a pH meter is suspect, use the spare pH meter. } \\
\text { If the spare meter is used, calibrate it in the field prior to use, } \\
\text { recording the pH information in the comments section of the chain- } \\
\text { of-custody form and on the pH Meter Calibration Record Form. }\end{array}$ \\
\hline
\end{tabular}


- Have any faulty instruments repaired or replaced as appropriate.

- Upon completion of the day's activities, store the $\mathrm{pH}$ meter, probe, and calibration solution according to the manufacturer's instructions. 


\begin{tabular}{|c|c|c|c|c|c|c|}
\hline \multicolumn{6}{|c|}{ pH Meter Calibration Record Form } & \multirow{3}{*}{ Buffer 10} \\
\hline & & & & & alibration & \\
\hline pH Meter \# & Operator & Date & $\begin{array}{l}\text { Exp. Date } \\
\text { Ch.cked }\end{array}$ & Buffer 4 & Buffer 7 & \\
\hline & & & & & & \\
\hline & & & & & & \\
\hline & & & & & & \\
\hline & & & & & & \\
\hline & & & & & & \\
\hline & & & & & & \\
\hline & & & & & & \\
\hline & & & & & & \\
\hline & & & & & & \\
\hline & & & & & & \\
\hline & & & & & & \\
\hline & & & & & & \\
\hline & & & & & & \\
\hline & & & & & & \\
\hline & & & & & & \\
\hline & & & & & & \\
\hline & & & & & & \\
\hline & & & & & & \\
\hline & & & & & & \\
\hline & & & & & & \\
\hline & & & & & & \\
\hline
\end{tabular}

Figure 4.7.1. $\mathrm{pH}$ Meter Calibration Record Form 


\subsection{FILTERED WATER SAMPLES}

\begin{tabular}{|c|c|}
\hline INTRODUCTION & $\begin{array}{l}\text { This is a procedure for collecting filtered water samples using a } \\
\text { disposable, factory-prepared water filtration cartridge containing a } \\
0.45-\mu \mathrm{m} \text { filter. This filtration procedure is used when collecting } \\
\text { transect and riverbank spring water samples for chemical analyses. } \\
\text { Several water pressure sources can be used for the procedure, including } \\
\text { a peristaltic pump, the water pump used in collecting transect samples } \\
\text { (Section } 4.4 \text { ), or a pressurized water tap. }\end{array}$ \\
\hline PERSONNEL & $\begin{array}{l}\text { Field sampling must be conducted by personnel who have received } \\
\text { training on these sampling procedures and are familiar with the } \\
\text { sampling equipment. } \\
\text { It is estimated that this procedure requires one (1) person for efficient } \\
\text { operation. }\end{array}$ \\
\hline $\begin{array}{l}\text { EQUIPMENT AND } \\
\text { SUPPLIES }\end{array}$ & $\begin{array}{l}\text { The following equipment and supplies may be needed for the } \\
\text { collection of filtered water samples: } \\
\text { - A disposable filter cartridge (with attached hose barbs) containing } \\
\text { a } 0.45-\mu m \text { filter (cartridge filters are not analyzed and are } \\
\text { discarded after use). } \\
\text { - Silicon tubing and connections for attaching the filtration } \\
\text { cartridge to the water source. } \\
\text { A Masterflex portable peristaltic pump including: } \\
\text { 1. Pump housing. } \\
\text { 2. Easy-load pump head. } \\
\text { 3. AC and DC power cords. } \\
\text { 4. Spare fuses ( } 0.25 \text { amp and } 2.5 \text { amp). } \\
\text { 5. Silicon tubing at least } 12-i n . \text { long (Masterflex } 15 \text { or } 24) \text { to } \\
\text { install in pump head. } \\
\text { Sample containers. } \\
\text { Sample labels and chain-of-custody forms. }\end{array}$ \\
\hline
\end{tabular}

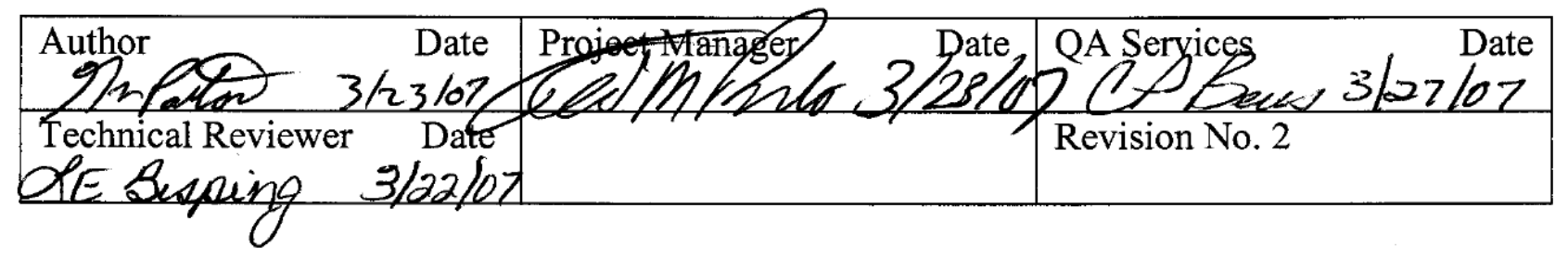




\begin{tabular}{|c|c|}
\hline & $\begin{array}{l}\text { For sample collections using a water faucet: } \\
\text { - Attach a piece of silicon tubing to the water faucet or water } \\
\text { supply line. At some locations a fitting with a hose barb is } \\
\text { already installed. } \\
\text { - Flush the faucet thoroughly, generally } 2 \text { to } 3 \text { minutes, before } \\
\text { collecting the sample. } \\
\text { - Attach the tubing to the appropriate hose barb on the disposable } \\
\text { filtration cartridge. Check that the water flow is in the direction } \\
\text { indicated on the disposable cartridge. } \\
\text { - Place the sample bottle on a stable surface. } \\
\text { - Turn on the water faucet to allow for a slow flow out of the filter; } \\
\text { adjust the water flow to maintain a steady stream without causing } \\
\text { a leak at the hose barbs. } \\
\text { - } \\
\text { - Dortridge (as in the water faucet procedure). The transect water } \\
\text { pump is designed to pressurize recreational vehicle water supplies } \\
\text { and has a pressure feedback mechanism that should automatically } \\
\text { adjust to maintain constant pressure. } \\
\text { custody form, then rexit end of the filtration cartridge to contact any } \\
\text { bottles are available. } \\
\text { - Allow approximately } 100 \text { mL of water to pass through the } \\
\text { filtration cartridge before collecting the sample. } \\
\text { parallel to the floor. This enables the entire filter surface to be } \\
\text { used and will maintain the highest flow rate with minimal } \\
\text { plugging. } \\
\text { provided sufficient flow can be maintained through the cartridge. } \\
\text { - } \\
\text { - } \\
\text { - }\end{array}$ \\
\hline
\end{tabular}


- If the water pressure becomes too great (e.g., a hose connection leak develops), the pump can be manually turned off and on as needed to regulate the pressure.

- Collect the sample using the same procedures used for collecting transect water samples (Section 4.4), except that the filtration cartridge is now inline.

- If multiple containers are to be filled at one sampling location (e.g., station \#1), one filtration cartridge can be used for all samples provided sufficient flow can be maintained through the cartridge. Upon moving to the next transect sampling location (e.g., station \#2), a new filtration cartridge should be used.

- If the filtration process is suspect, make a note on the chain-ofcustody form, then re-collect the samples if additional filters and sample containers are available.

- If problems occur with the transect-sampling water pump, a Masterflex peristaltic pump can be used in its place (see the Masterflex pump operating procedures below).

For sample collections using a Masterflex peristaltic pump:

A Masterflex pump can be operated using a rechargeable internal battery, an external 12-volt DC power supply, or an external AC power supply. The AC power supply should be used where possible (e.g., filtered water samples at the Priest Rapids Dam station).

\section{To check the charge on the Masterflex pump internal battery:}

- $\quad$ Turn the power switch to OFF.

- Turn the operations dial to INTERNAL BATTERY OPERATION.

- Turn the power switch to ON.

- $\quad$ Press the red test button for the internal battery. If the battery is charged, the green test light will light up.

NOTE: If the internal battery must be charged, it can be charged using either an AC or DC power source. If the battery has been completely discharged it will not recharge on the RECHARGE ON AC setting until it has received a short recharge using a DC power source. 


\section{For an AC power source recharge:}

- Turn the power switch to OFF.

- Turn the operation dial to RECHARGE ON AC.

- Plug the pump into the AC power source using the AC power cord.

- Turn the power switch to ON, and allow the unit to recharge for 12 to 16 hours. When the appropriate charge has been reached, the red indicator light will illuminate.

- Turn the power switch to OFF, and unplug the AC power cord. Do not overcharge the internal battery.

\section{For a DC power source recharge:}

- Follow the instructions for an AC recharge but substitute the DC power cord and set the operation dial to RECHARGE ON $12 \mathrm{~V}$ DC.

\section{Masterflex pump operating procedures:}

- Connect the pump to the appropriate power source.

NOTE: Masterflex pumps are equipped with “easy-load” pump heads that require at least $12 \mathrm{in}$. of flexible silicon tubing (Masterflex C-Flex L/S 15 or L/S 24 or equivalent) to operate. The peristaltic pump uses a set of pinch-rollers to compress the silicon tubing and push the water through the tubing.

- Insert the silicon tubing into the pump head by raising the blackhandled bar.

- Lower the black-handled bar to close the pump head during operation.

- On each side of the pump head there is a black tension adjuster that prevents the silicon tubing from "moving" through the pump head. Adjust the tension setting as needed to the minimal tension necessary to secure the tubing.

- Plumb the inlet side of the pump head to the water supply. 


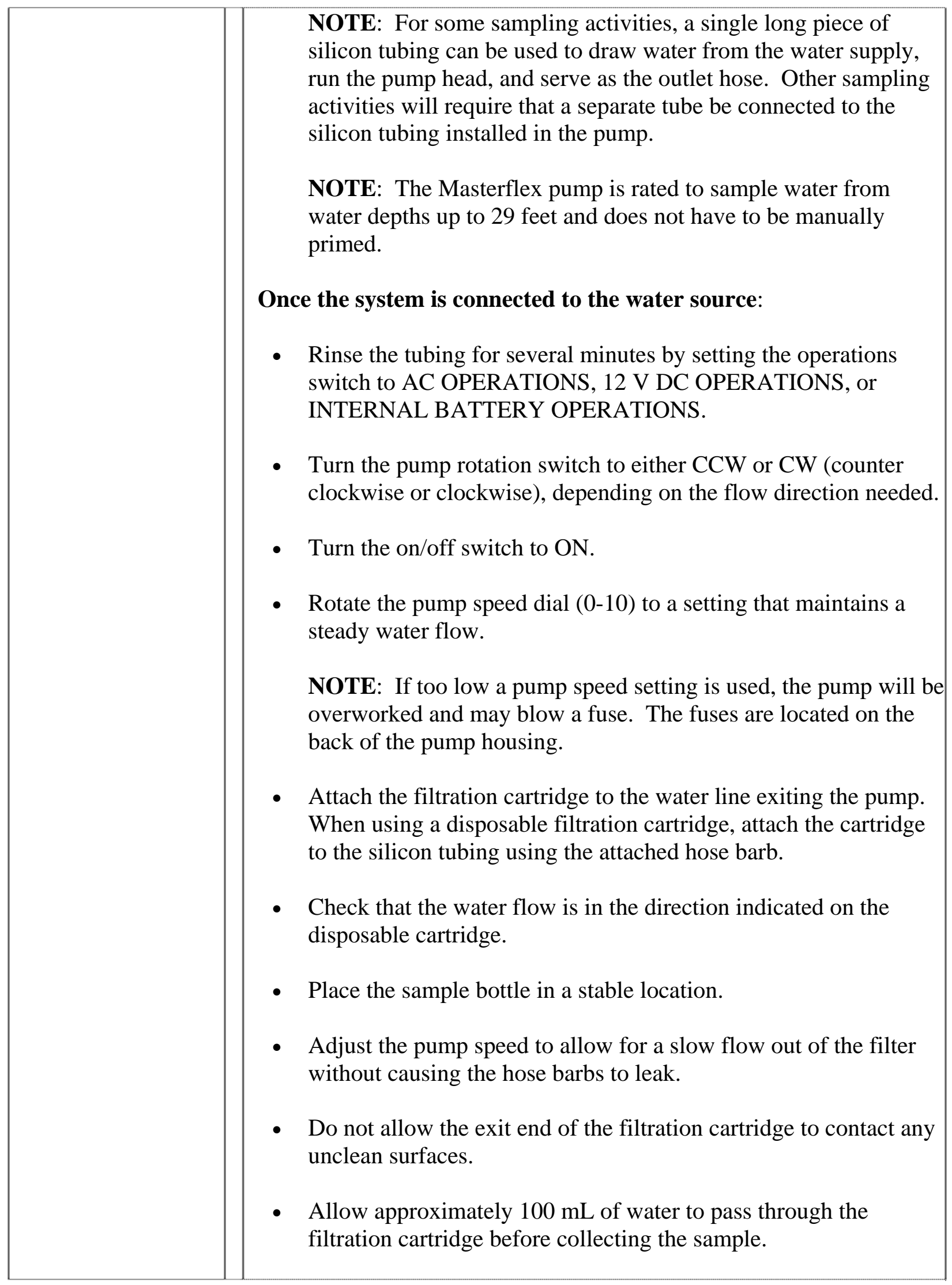




\begin{tabular}{|l||l}
\hline & $\begin{array}{l}\text { During sampling: } \\
\text { Hold the filtration cartridge with the filter parallel to the floor. } \\
\text { This enables the entire filter surface to be used and will maintain } \\
\text { the highest flow rate with minimal plugging. }\end{array}$ \\
$\begin{array}{l}\text { If the filtration process is suspect: } \\
\text { Make a note on the chain-of-custody form then re-collect the } \\
\text { samples if additional filters and bottles are available. }\end{array}$ \\
\hline
\end{tabular}




\subsection{COLUMBIA RIVER SEDIMENT}

INTRODUCTION

PERSONNEL

EQUIPMENT AND SUPPLIES
Samples of Columbia River surface sediment are collected annually and analyzed for radionuclides and chemicals. Samples are collected from specific backwater areas along the Hanford Reach shoreline and from the reservoirs behind McNary Dam (downstream of the site) and Priest Rapids Dam (upstream of the site). In both reservoirs, samples are collected along a transect line oriented perpendicular to the shoreline. Samples are collected in this manner to determine if concentration gradients exist within the reservoirs.

Field sampling must be conducted by personnel who have received appropriate training on these sampling procedures and are familiar with the sampling and boating equipment.

The following equipment and supplies may be needed for the collection of Columbia River sediment samples:

- A depth recorder.

- A cellular telephone or two-way radio.

- $\quad$ Hip boots.

- A bucket.

- A scale for weighing samples.

- $\quad$ Sample containers.

- An ice chest containing ice.

- A large plastic spoon for scooping.

- A sufficient number of medium-size transparent plastic bags.

- A sufficient number of large-size transparent plastic bags.

- A large plastic container (could be an ice chest).

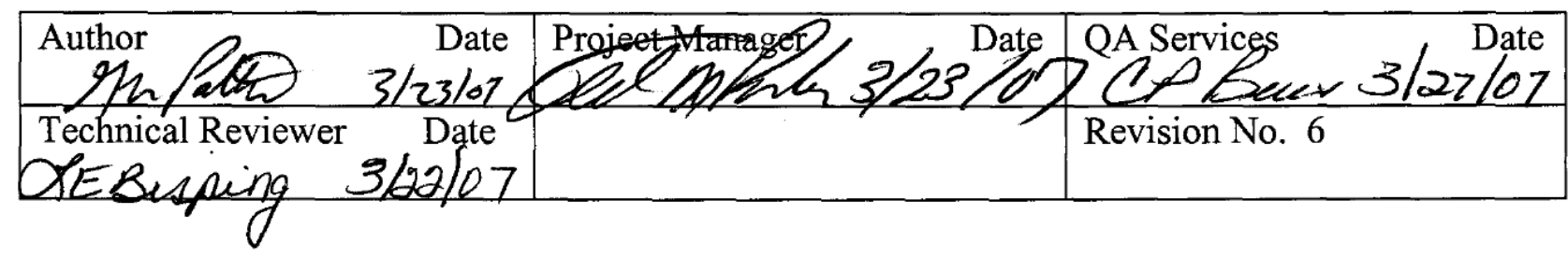




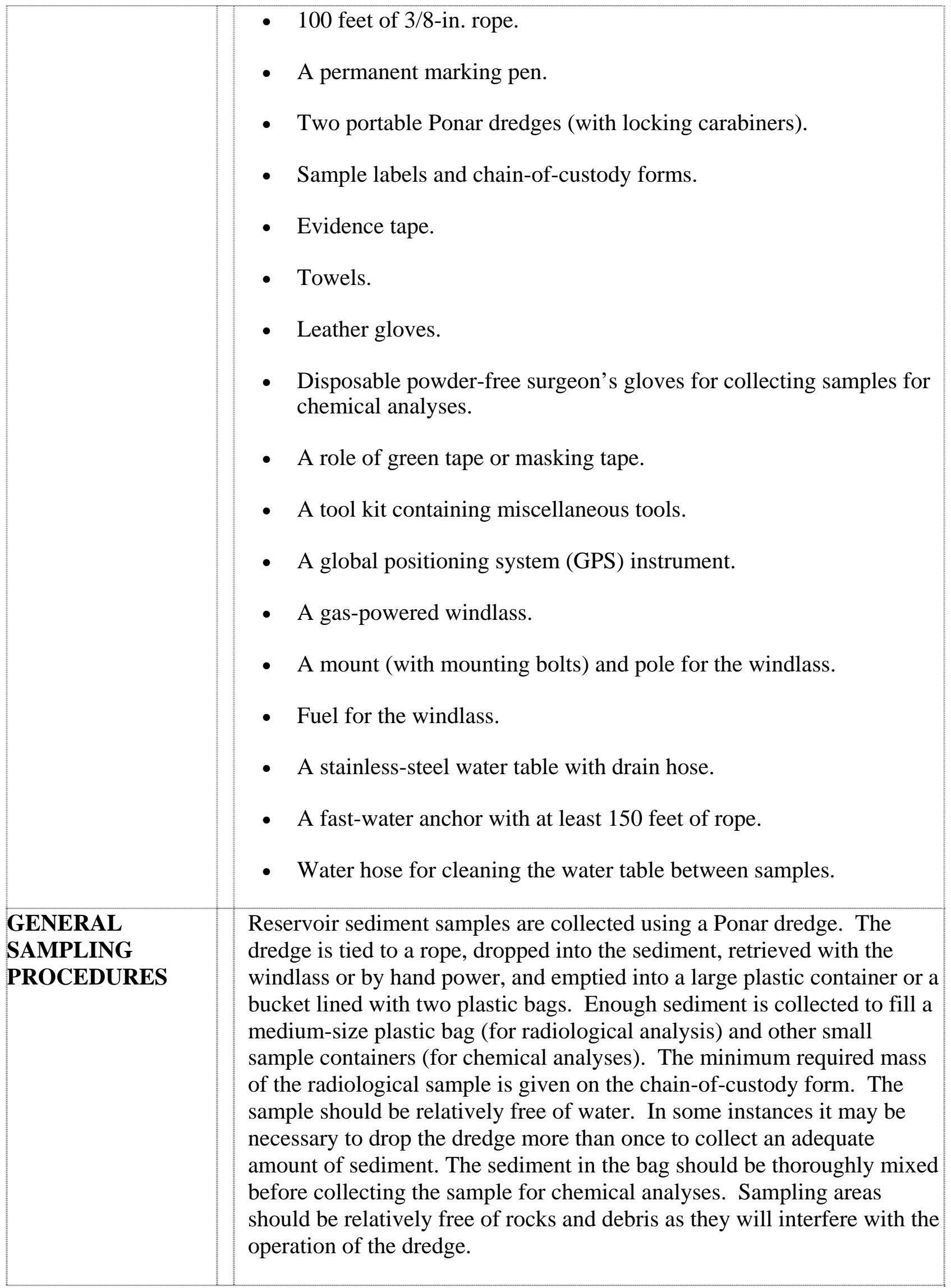




\begin{tabular}{|c|c|}
\hline & $\begin{array}{l}\text { Reservoir sediment samples are collected from several locations across } \\
\text { the width of the river. A transect line perpendicular to the shoreline is } \\
\text { established based on sampling landmarks or GPS coordinates from past } \\
\text { sampling efforts. Under most circumstances, specific sampling locations } \\
\text { will be selected by "eyeball," using previously identified shoreline } \\
\text { landmarks. The coordinates of the individual sampling locations will then } \\
\text { be determined using a portable GPS instrument (see Section 8.5). } \\
\text { Slough samples can be collected from a boat or from the shoreline using a } \\
\text { dredge or plastic spoon as described in the procedures outlined below. To } \\
\text { the extent possible, samples should not be collected in locations that dry } \\
\text { up because of seasonal changes in river flow or intermittent fluctuations } \\
\text { in river level. GPS coordinates should be obtained at all sampling } \\
\text { locations and these coordinates should be recorded on the chain-of- } \\
\text { custody form. }\end{array}$ \\
\hline $\begin{array}{l}\text { PRE-SAMPLING } \\
\text { EQUIPMENT } \\
\text { SETUP }\end{array}$ & $\begin{array}{l}\text { Before launching the boat: } \\
\text { Install the water sampling table with drain hose on the boat, and attach the } \\
\text { anchor to the electric winch line located on the bow of the boat. Secure } \\
\text { the anchor to the boat so that it will not move or fall off when the boat is } \\
\text { being towed. To help prevent back injury, the installation of equipment } \\
\text { should be accomplished by at least three individuals. } \\
\text { Check to see that the gas tank and oil reservoir on the windlass engine are } \\
\text { full prior to leaving for the field. One tank of gas is usually sufficient; } \\
\text { however, carry extra fuel for an extended sampling day. The windless } \\
\text { engine uses normal gasoline (not a gas/oil mix). If the windlass fails to } \\
\text { operate during a sampling trip, the dredge can be retrieved manually, and } \\
\text { sampling should continue. } \\
\text { Test the windlass to verify that it is working properly. }\end{array}$ \\
\hline $\begin{array}{l}\text { OPERATION OF } \\
\text { THE WINDLASS }\end{array}$ & $\begin{array}{l}\text { Install the windlass mount and pole to the jet boat by passing it through } \\
\text { one of the metal rod holders on the boat. The windlass should be } \\
\text { mounted on the same side as the water table. Attach the windlass and } \\
\text { motor to the mounting pole. } \\
\text { To recover the sediment dredge using the windlass: } \\
\text { - Start the windlass engine using the starter cord; adjust the choke as } \\
\text { needed. } \\
\text { - } \text { Pass the sampler rope through the overhead pulley on the pole } \\
\text { Wrap the rope around the windlass wheel one time (in the direction } \\
\text { of rotation). }\end{array}$ \\
\hline
\end{tabular}




\begin{tabular}{|c|c|}
\hline & $\begin{array}{l}\text { - Pull down on the rope with a hand-over-hand motion to recover the } \\
\text { dredge. Hold the rope in place once the dredge is at the desired } \\
\text { height. } \\
\text { - Using the pole mount, swing the dredge into position above the } \\
\text { water table; the dredge can be lowered by moving the rope up } \\
\text { toward the windlass wheel. Remove the rope from the windlass } \\
\text { wheel before filling the sampling containers. } \\
\text { - The rope should be removed from the windlass wheel when the } \\
\text { sampler is being deployed; however, the overhead pulley on the pole } \\
\text { mount can be used if needed. } \\
\text { Turn off the windlass engine after all sediment has been collected at } \\
\text { that location. } \\
\text { CAUTION: Leather gloves should be worn when setting the dredge } \\
\text { to prevent injury to fingers. Leather gloves should be worn when } \\
\text { lowering or raising the dredge with the windlass. Be alert to pinch } \\
\text { points on the windlass and pulley. Use caution when swinging the } \\
\text { dredge using the pole mount. Avoid hot surfaces on the windlass } \\
\text { engine. }\end{array}$ \\
\hline $\begin{array}{l}\text { SAMPLE } \\
\text { COLLECTION } \\
\text { PROCEDURES }\end{array}$ & $\begin{array}{l}\text { - Proceed to a sampling location. } \\
\text { - Anchor the boat at one of the sampling locations along the transect } \\
\text { line and shut off the boat motor(s). } \\
\text { NOTE: Depending on currents, anchoring may not be necessary at } \\
\text { all locations. } \\
\text { - } \quad \text { Record the sampling depth on the chain-of-custody form. } \\
\text { - When using the dredge from a boat, securely connect one end of the } \\
\text { 3/8-in. rope to the dredge. Check that the knot is tight and couplings } \\
\text { are tightly fastened. A locking carabiner can also be used to secure } \\
\text { - Secure the other end of the rope to the boat to prevent loss of the } \\
\text { dredge. } \\
\text { - Set an ice chest at the base of the water table. } \\
\text { Place the large plastic storage container (similar size as the ice chest) } \\
\text { on top of the ice chest. }\end{array}$ \\
\hline
\end{tabular}


- Place a large plastic bag inside the storage container with the mouth of the bag open and draped over the container rim. The container should be positioned so the dredge sampler can be set on the edge of the water table and, when opened, the sediment will drop into the large plastic bag.

- $\quad$ Fit one medium plastic bag inside another so that the mouths of both bags can be opened as one bag. Place the plastic bags in a bucket, and drape the mouths of both bags over the bucket rim.

- "Set" the mouth of the dredge in the sampling position (dredge mouth open).

- Insert the trigger/spring into position on the dredge arms. Hold the trigger/spring in place while applying tension to the rope. The dredge mechanism will remain open during deployment as long as tension is held on the rope.

CAUTION: When handling the open dredge mechanism; always keep hands and fingers away from the dredge mouth and scissor arms to prevent pinch injuries.

- Lower the dredge to the river bottom (maintaining tension on the rope). Contact with the bottom, and the release of tension on the rope, will trigger the dredge mechanism to close. Avoid abrupt movement while lowering the dredge as this may cause the dredge to close prematurely.

- $\quad$ Once the dredge has contacted the bottom, very slowly pull the rope to take out the slack. Continue to slowly pull the rope until the dredge triggers (you can usually feel the dredge close). In some cases, a sharp tug on the rope may facilitate triggering of the dredge.

- $\quad$ Pull the dredge to the surface using the capstan winch.

- Drain excess water from the dredge by gently tipping the closed dredge and allowing water to drain though the rubber flaps covering the top of the dredge.

- $\quad$ Set the dredge on the table edge. Open the dredge, and empty its contents into the plastic bag-lined storage container.

- If additional sediment is needed, repeat the sampling process. 
- If the sediment is being collected by wading in from the shoreline (a slough sample), either the dredge or plastic spoon may be used to collect the sediment. When using the dredge, it will have to be pushed into the mud. Attaching a short length of rope, or a locking carabiner to the top of the dredge will facilitate handling.

- When enough sediment has been collected, put on disposable surgeon's gloves and thoroughly mix the sediment with a plastic spoon.

- Spoon sediment from the large plastic container into the bucket lined with two plastic bags.

- Decant excess water from the sample bag in the bucket, if necessary, being careful to avoid the loss of fine sediments.

- Weigh the sample bag, and continue to add sediment until an adequate amount (as specified on the chain-of-custody form) has been added.

- Verify that the container for the sample for chemical analyses is the correct one for the location. These containers are usually prelabeled.

- Fill the sample container using the plastic spoon.

- $\quad$ Cap the container, and seal the cap with evidence tape.

- $\quad$ Place the container on ice in the ice chest.

- Use the GPS instrument to determine the coordinates of the sampling location. Record the coordinates on the chain-of-custody form.

- Enter all other pertinent sampling information on the chain-ofcustody form and sample label.

- Verify that the sample number and sampling date on the chain-ofcustody form match the sample number and sampling date on the sample label.

- Close and tape the mouth of the inner plastic bag in the bucket.

- $\quad$ Place the sample label between the two plastic bags, print side out, so that it can be read through the wall of the outer bag. It is not necessary to remove the paper from the back of the label. 


\begin{tabular}{|l||l|l|}
\hline & $\begin{array}{l}\text { Close and tape the mouth of the outer plastic bag. } \\
\text { - } \begin{array}{l}\text { Rinse any spilled sediment off of the water table, using buckets of } \\
\text { river water or water from the boat-mounted water pump, before } \\
\text { proceeding to the next location. }\end{array} \\
\begin{array}{l}\text { CHAIN-OF- } \\
\text { CUSTODY FORM } \\
\text { AND SAMPLE } \\
\text { SUBMISSION } \\
\text { REQUIREMENT } \\
\text { Thefore collecting the next sample. }\end{array}\end{array} \mid \begin{array}{l}\text { See Section 8.1, Chain-of-Custody Forms, for further requirements for } \\
\text { completing chain-of-custody forms and submitting samples to an } \\
\text { analytical laboratory. }\end{array}$ \\
\hline
\end{tabular}




\subsection{SOIL AND VEGETATION SAMPLING}

Soil and uncultivated vegetation samples are collected because atmospheric contaminants from Hanford have the potential to deposit on the ground and plant foliage. Additionally, contaminants that accumulate in the soil over time can potentially be taken up by plants.

SESP soil and terrestrial vegetation samples are collected periodically at undisturbed locations on the Hanford Site, and at undisturbed, non-irrigated locations off the site. Procedures for collecting soil and vegetation samples are discussed in the following sections:

- Surface soil samples (Section 5.1).

- Terrestrial vegetation samples (Section 5.2).

\begin{tabular}{|c|c|c|}
\hline Author/f Date & 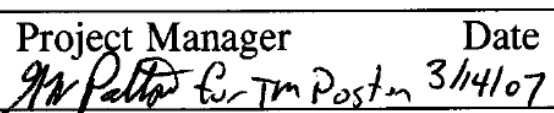 & QA Services 3/15/07 \\
\hline $\begin{array}{lr}\text { Technical Reviewer } & \text { Date } \\
\text { OrE BuRing } & 3 /, 3 / \Delta 7\end{array}$ & & Revision No. 5 \\
\hline
\end{tabular}




\subsection{SURFACE SOIL SAMPLES}

\begin{tabular}{|c|c|}
\hline INTRODUCTION & $\begin{array}{l}\text { Soil samples are collected at a number of locations on and around the } \\
\text { Hanford Site and are analyzed for selected radionuclides. These samples } \\
\text { provide an indication of the buildup of radionuclides in the soil. Samples } \\
\text { are collected from undisturbed areas. }\end{array}$ \\
\hline $\begin{array}{l}\text { EQUIPMENT AND } \\
\text { SUPPLIES }\end{array}$ & $\begin{array}{l}\text { The following equipment may be needed to collect soil samples: } \\
\text { - } \quad \text { Masking tape. } \\
\text { - } 14 \text { - x 17-in. plastic bags. } \\
\text { - A trowel. } \\
\text { - } \quad \text { Sample labels and chain-of-custody form. } \\
\text { - A permanent marking pen. } \\
\text { - A portable spring scale. } \\
\text { - A container of water for cleaning the sampler and trowel. } \\
\text { - } \text { Cloth or paper towels. }\end{array}$ \\
\hline $\begin{array}{l}\text { SAMPLING } \\
\text { INFORMATION }\end{array}$ & $\begin{array}{l}\text { Established soil sampling locations are usually near air sampling stations. } \\
\text { Some sampling locations are not near air sampling stations and are visited } \\
\text { only when soil samples are collected. } \\
\text { - If an established sampling site has come under cultivation, or has } \\
\text { been otherwise disturbed since it was last sampled (sampling efforts } \\
\text { may be years apart), notify the sample collection task manager or the } \\
\text { soil and vegetation task manager so that an alternate collection site } \\
\text { can be identified. } \\
\text { - When collecting soil samples, avoid spots that are wind eroded, } \\
\text { rocky, disturbed significantly by animals, or heavily vegetated. }\end{array}$ \\
\hline
\end{tabular}

\begin{tabular}{|c|c|c|}
\hline Authoy /f $3 / 13 / 0$ ?ate & 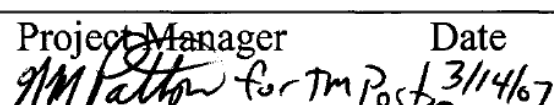 & $\begin{array}{lc}\text { QA Services } & \text { Date } \\
\text { Cxyees } & 3 / 15107\end{array}$ \\
\hline 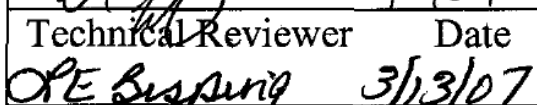 & & Revision No. 5 \\
\hline
\end{tabular}


SAMPLE COLLECTION

\section{When collecting soil samples:}

- Select five spots that are at least 10 paces apart within the desired sampling area.

- Place the "cookie cutter" sampler on one of the spots selected, and press it into the soil until its top is level with the soil surface.

- Hold the sampler vertical and use the trowel to clear away the soil around the rim of the cookie cutter so that the trowel can be inserted under the sampler.

- $\quad$ Slide the trowel under the sampler to cut the soil level with the bottom edge of the sampler.

- Lift the sampler and trowel together (the trowel is holding the soil in the sampler).

- Turn the sampler and the trowel over so that the soil is pointing up.

- Use the trowel to trim excess soil projecting over the rim of the sampler.

- Pour the soil from the sampler into a plastic bag.

- Repeat this procedure at the remaining four spots, putting the soil from all five spots into the same plastic bag.

- Enter all pertinent sampling information on the chain-of-custody form and sample label.

- Verify that the sample number and sampling date on the chain-ofcustody form match the sample number and sampling date on the sample label.

- Remove as much air from the bag as possible then close and tape the mouth of the bag.

- $\quad$ Put the plastic bag containing the sample into another plastic bag (double bag).

- $\quad$ Place the sample label between the plastic bags so that the information on the label faces out and can be read through the wall of the outside bag. It is not necessary to peel the back off the label.

- $\quad$ Close and tape the mouth of the second plastic bag. 


\begin{tabular}{|c|c|}
\hline & $\begin{array}{l}\text { - Use the GPS instrument to obtain coordinates for the sampling } \\
\text { location (see Section 8.5). } \\
\text { - Record the GPS coordinates on the chain-of-custody form to the left } \\
\text { of the description column. } \\
\text { - Wash and dry the sampler and the trowel before collecting at another } \\
\text { location. }\end{array}$ \\
\hline $\begin{array}{l}\text { CHAIN-OF- } \\
\text { CUSTODY FORM } \\
\text { AND SAMPLE } \\
\text { SUBMISSION } \\
\text { REQUIREMENTS }\end{array}$ & $\begin{array}{l}\text { See Section } 8.1 \text {, Chain-of-Custody Forms, for requirements for completing } \\
\text { chain-of-custody forms and submitting samples to an analytical laboratory. } \\
\text { Deliver the samples to the appropriate analytical laboratory as soon as } \\
\text { possible after collection. If samples cannot be delivered the day they are } \\
\text { collected, store them in a secure location overnight. } \\
\text { Archived samples are stored in a locked or limited access location at } \\
\text { PNNL until they are needed. }\end{array}$ \\
\hline
\end{tabular}




\subsection{TERRESTRIAL VEGETATION SAMPLES}

\begin{tabular}{|c|c|}
\hline INTRODUCTION & $\begin{array}{l}\text { Terrestrial vegetation samples are collected to establish background } \\
\text { concentrations of both naturally occurring and fallout radionuclides and to } \\
\text { assess any radionuclide buildup that might be attributable to Hanford Site } \\
\text { operations. Samples of new-growth vegetation are collected. }\end{array}$ \\
\hline $\begin{array}{l}\text { EQUIPMENT AND } \\
\text { SUPPLIES }\end{array}$ & $\begin{array}{l}\text { The following equipment may be needed to collect vegetation samples: } \\
\text { - } \quad \text { Pruning shears or scissors. } \\
\text { - } \quad \text { Peather gloves. } \\
\text { - Masking tape. } \\
\text { - A portable spring scale. } \\
\text { - Sample labels and chain-of-custody form. } \\
\text { - A permanent marking pen. } \\
\text { - A global positioning system (GPS) instrument. }\end{array}$ \\
\hline $\begin{array}{l}\text { SAMPLING } \\
\text { INFORMATION }\end{array}$ & $\begin{array}{l}\text { Most established vegetation sampling locations are near air sampling } \\
\text { stations. Some sampling locations are not near air sampling stations and } \\
\text { are visited only when vegetation samples are collected. } \\
\text { - If an established sampling site has come under cultivation, or has } \\
\text { been otherwise disturbed since it was last sampled (sampling efforts } \\
\text { may be years apart), notify the sample collection task manager or the } \\
\text { soil and vegetation task manager so that an alternate collection site } \\
\text { can be identified. } \\
\text { - Samples at most locations are collected from perennial shrubs } \\
\text { (usually sagebrush and rabbitbrush) in approximately the same } \\
\text { percentages as they grow at each site (Columbia River shoreline } \\
\text { samples are an exception to this, see the river section below). }\end{array}$ \\
\hline
\end{tabular}

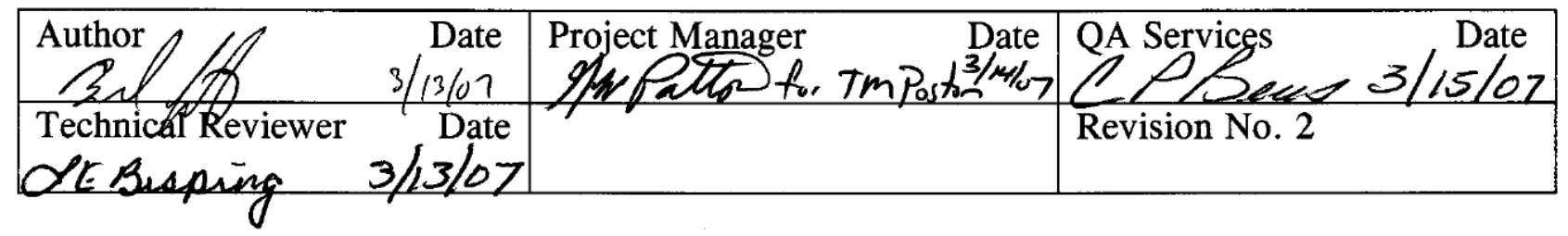




\begin{tabular}{|c|c|}
\hline & $\begin{array}{l}\text { For example, if a site appears to consist of } 75 \% \text { sagebrush and } 25 \% \\
\text { rabbitbrush, then the sample collected should be approximately } 75 \% \\
\text { sagebrush and } 25 \% \text { rabbitbrush. }\end{array}$ \\
\hline $\begin{array}{l}\text { SAMPLE } \\
\text { COLLECTION }\end{array}$ & 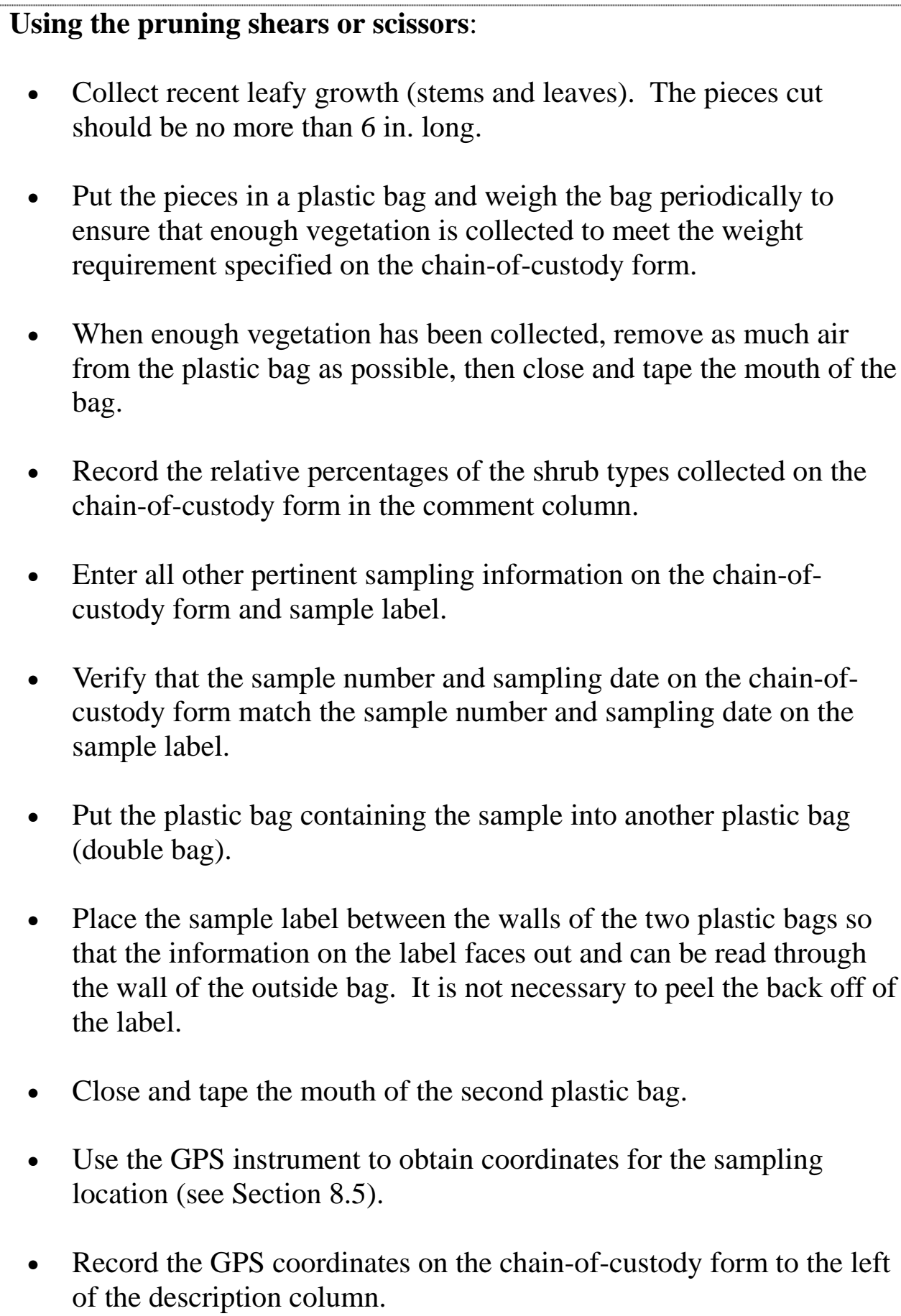 \\
\hline
\end{tabular}




\begin{tabular}{|c|c|}
\hline $\begin{array}{l}\text { COLUMBIA } \\
\text { RIVER } \\
\text { SHORELINE } \\
\text { SAMPLES }\end{array}$ & $\begin{array}{l}\text { Vegetation samples are sometimes collected along the Columbia River } \\
\text { shoreline. Some species of shoreline vegetation are rare and endangered. } \\
\text { The soil and vegetation task manager will consult with a plant specialist } \\
\text { to determine which species of shoreline vegetation in each collection area } \\
\text { are acceptable to collect. Sample collection personnel will include a } \\
\text { specialist who can identify the species to be collected. Shoreline samples } \\
\text { are collected using the procedures outlined above. } \\
\text { The following are some of the shoreline species routinely collected: } \\
\text { - Wild onion bulbs and stalks. } \\
\text { - Mulberry fruit, leaves, and twigs. } \\
\text { - Asparagus plants (adult). }\end{array}$ \\
\hline $\begin{array}{l}\text { TRITIUM } \\
\text { SAMPLES }\end{array}$ & $\begin{array}{l}\text { Water samples are occasionally obtained from vegetation and analyzed } \\
\text { for tritium. Samples are collected and labeled and data are recorded using } \\
\text { the SAMPLE COLLECTION procedures outlined above. } \\
\text { To obtain water from vegetation: } \\
\text { - Clip recent leafy growth (stems and leaves) and put them in a plastic } \\
\text { bag. } \\
\text { - When the bag is full of vegetation, seal the mouth of the bag with } \\
\text { tape. } \\
\text { - Leave the bag in the sun. As the temperature in the bag increases, } \\
\text { moisture from the plants will condense on the inside wall of the bag. } \\
\text { - After a few hours, pour the moisture that has collected in the bag } \\
\text { into a sample container. } \\
\text { - If more water is needed, reseal the bag and allow it to sit in the sun } \\
\text { longer. } \\
\text { When enough water has been collected to meet the sample size } \\
\text { requirement specified on the chain-of-custody form, the bag and } \\
\text { vegetation can be discarded. }\end{array}$ \\
\hline
\end{tabular}




\begin{tabular}{|l|l|l|}
$\begin{array}{l}\text { CHAIN-OF- } \\
\text { CUSTODY FORM } \\
\text { AND SAMPLE }\end{array}$ & $\begin{array}{l}\text { See Section 8.1, Chain-of-Custody Forms, for requirements for } \\
\text { completing chain-of-custody forms and submitting samples to an } \\
\text { analytical laboratory. } \\
\text { SUBMISSION } \\
\text { REQUIREMENTS }\end{array}$ & $\begin{array}{l}\text { Deliver the samples to the appropriate analytical laboratory as soon as } \\
\text { possible after collection. If samples cannot be delivered the day they are } \\
\text { collected, store them in a refrigerator or freezer overnight. } \\
\text { Archived samples are stored in a locked cooler or freezer at PNNL until } \\
\text { they are needed. }\end{array}$
\end{tabular}




\subsection{FOOD AND FARM PRODUCTS SAMPLING PROCEDURES}

A variety of food and farm products samples are collected near the Hanford Site. These products are collected and analyzed because they are a potential pathway for public exposure to Hanford produced radionuclides. The products routinely collected include:

- Milk (Section 6.1)

- $\quad$ Crops (Section 6.2)

- Wine (Section 6.3)

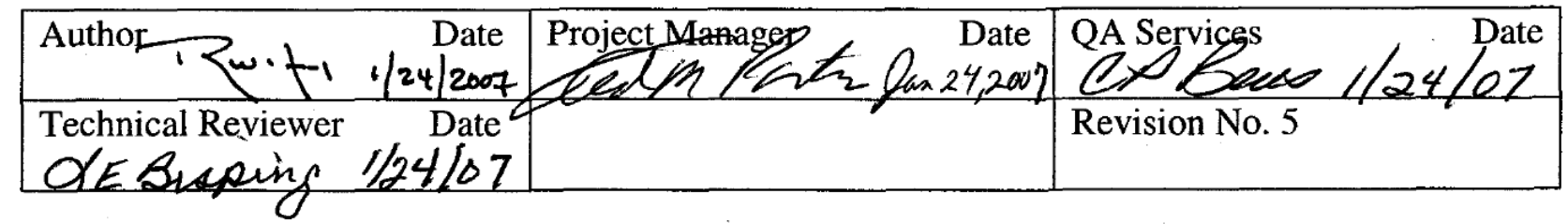




\subsection{MILK SAMPLES}

\begin{tabular}{|c|c|}
\hline INTRODUCTION & $\begin{array}{l}\text { Milk samples are analyzed for iodine-129, strontium- } 90 \text {, tritium, and } \\
\text { gamma emitters. Samples are collected at locations downwind of the site } \\
\text { near the site boundary, and at generally upwind, distant locations where } \\
\text { background concentrations are expected. }\end{array}$ \\
\hline $\begin{array}{l}\text { MATERIALS } \\
\text { NEEDED }\end{array}$ & $\begin{array}{l}\text { The following materials will be needed when collecting milk samples: } \\
\text { - } \quad \text { Sample containers. } \\
\text { - } \quad \text { Lurge ice chest and ice. } \\
\text { - Sample labels. } \\
\text { - } \quad \text { Chain-of-custody forms and daily trip log report. } \\
\text { - Marking pen. } \\
\text { - Graduated cylinder or an equivalent volume measuring device. } \\
\text { Cash to pay for milk. }\end{array}$ \\
\hline $\begin{array}{l}\text { SAMPLE } \\
\text { COLLECTION }\end{array}$ & $\begin{array}{l}\text { Obtain cash for milk samples from the sample collection task leader. } \\
\text { Samples are collected from one to three dairies in each sampling area. The } \\
\text { specific dairies sampled in each area are identified on the monthly SESP } \\
\text { sampling calendar. The size of the sample needed from each dairy will } \\
\text { depend on the number of dairies supplying milk and the minimum sample } \\
\text { size indicated on the chain-of-custody form. Equal amounts from each } \\
\text { dairy will be combined to form one or two samples as large as the } \\
\text { minimum sample sizes. } \\
\text { Milk may be provided to the SESP sample collector by dairy personnel or } \\
\text { the SESP sample collector may have to obtain milk directly from a raw } \\
\text { milk storage tank (use the funnel if necessary). Usually the SESP sample } \\
\text { collector obtains the milk from a storage tank. }\end{array}$ \\
\hline
\end{tabular}

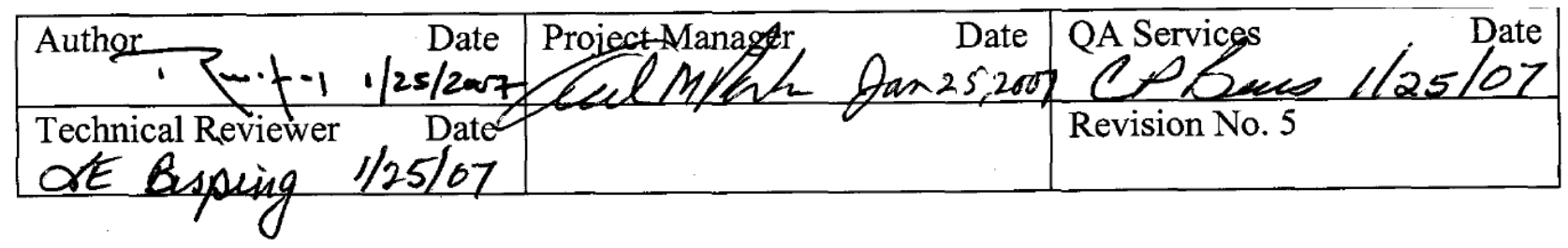


Samples from individual dairies are usually collected in 4-liter (1-gallon) plastic milk jugs. However, if only one dairy is sampled, the milk should be collected in a container big enough to hold the minimum sample size indicated on the chain-of-custody form (usually 6 or 7 liters).

Once the sample is obtained, use the marking pen to label the container with the date and sample number.

Place the labeled milk container in the ice chest with ice for transport. Protect milk samples from degradation or spoilage by keeping them cold until they are delivered to storage or to the appropriate laboratory.

When milk samples are obtained from multiple dairies in one sampling area, they are combined (composited) to create one 6 liter sample. Every 6 months, an additional 1 liter composite sample for iodine-129 analysis is also collected. To generate the composite samples, mix equal volumes of milk from each dairy into a clean container large enough to hold the entire 6 liters (or 7 liters) of milk. The 1-liter sample analyzed for iodine-129 should be transferred from this composite-sample container to a smaller 1-liter bottle prior to submitting the samples for analysis.

Do not "eyeball" the volume sizes. When creating a composite sample, volumes must be measured.

Milk samples can be composited in the field or at PNNL.

Once the milk is composited and the sample is poured into the proper container(s), write the date on the sample label (along with the actual sample size if it differs from the sample size printed on the label), and attach the sample label to the container. If necessary, use clear tape to attach the label to the container.

The used 1-gallon sample containers and any excess milk can be thrown away.

Record the sampling date and sample size (in liters or milliliters) on the chain-of-custody form. Write the dairy names in the description column to the left of the double vertical lines.

Return all remaining cash, and receipts for all samples, to the sample collection task leader. If the dairy does not supply a receipt, the SESP sample collector should create a receipt. All of the milk purchases in one sampling area can be accounted for on one receipt. 


\begin{tabular}{|l|l|}
\hline $\begin{array}{l}\text { COMPLETING } \\
\text { CHAIN-OF- } \\
\text { CUSTODY FORMS }\end{array}$ & $\begin{array}{l}\text { See Section 8.1, Chain-of-Custody Forms, for procedures for completing } \\
\text { chain-of-custody forms. }\end{array}$ \\
\hline $\begin{array}{l}\text { SUBMITTING } \\
\text { SAMPLES FOR } \\
\text { ANALYSIS }\end{array}$ & $\begin{array}{l}\text { Deliver the samples to the laboratory's sample-receiving area as soon as } \\
\text { possible after collection. If samples cannot be delivered the day they are } \\
\text { collected, store them in a refrigerator overnight. See Section 8.1, Chain- } \\
\text { of-Custody Forms, for procedures for submitting samples to an analytical } \\
\text { laboratory. }\end{array}$ \\
\hline
\end{tabular}




\subsection{CROP SAMPLES}

\begin{tabular}{|c|c|}
\hline INTRODUCTION & $\begin{array}{l}\text { Crops routinely sampled around the Hanford Site include leafy vegetables, } \\
\text { fruit, vegetables (e.g., potatoes), and alfalfa. These samples are used to } \\
\text { determine if Hanford produced radionuclides are present in locally } \\
\text { produced food or livestock feed. }\end{array}$ \\
\hline $\begin{array}{l}\text { MATERIALS } \\
\text { NEEDED }\end{array}$ & $\begin{array}{l}\text { The following materials may be needed when collecting crop samples: } \\
\text { - } \quad \text { Plastic bags. } \\
\text { - } \quad \text { Masking clippers or pruning shears. } \\
\text { - } \quad \text { Portable spring scale. } \\
\text { - Sample labels. } \\
\text { - Chain-of-custody forms and daily trip log report. } \\
\text { - Marking pen. } \\
\text { - Cash to pay for products. } \\
\text { - Global positioning system (GPS) instrument. }\end{array}$ \\
\hline $\begin{array}{l}\text { SAMPLE } \\
\text { COLLECTION }\end{array}$ & $\begin{array}{l}\text { Table } 6.2 .1 \text { outlines the instructions for collecting crop samples. Cash for } \\
\text { crop purchases can be obtained from the sample collection task leader. } \\
\text { Samples are collected from designated sampling areas or locations. Two } \\
\text { SESP samples are collected from each sampling area or location. One of } \\
\text { the samples is submitted to the analytical laboratory for analysis. The } \\
\text { other is archived at PNNL pending a review of the analytical results from } \\
\text { the first sample. Samples for the U.S. Food and Drug Administration } \\
\text { (FDA) and Washington State Department of Health (DOH) may also be } \\
\text { collected. } \\
\text { Place the collected sample into a plastic bag. }\end{array}$ \\
\hline
\end{tabular}

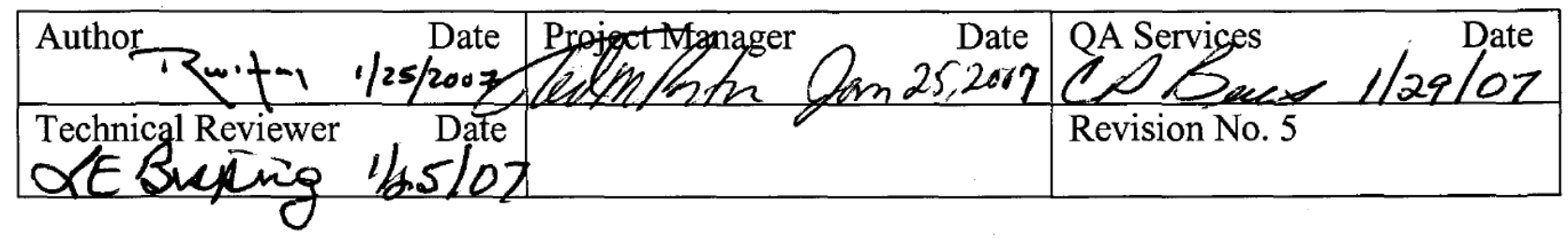




\begin{tabular}{|c|c|}
\hline & $\begin{array}{l}\text { Using the marking pen, label the bag with the collection date, sample } \\
\text { number, and crop type. } \\
\text { Seal the bag with tape. } \\
\text { If more than one bag is used, write } 1 \text { of } 2 \text {, } 2 \text { of } 2 \text {, or } 1 \text { of } 3 \text {, } 2 \text { of } 3 \text {, and } 3 \text { of } \\
3 \text { on the bags along with the identification information outlined above. } \\
\text { Obtain the GPS coordinates of the field or orchard where the crop samples } \\
\text { were grown (see Section } 8.5 \text {, Determining Geographic Positions). If the } \\
\text { samples are purchased from a roadside market or vender, find out where } \\
\text { the field or orchard is located, drive there, and obtain GPS coordinates } \\
\text { (lat/long). The coordinates should be written on the chain-of-custody form } \\
\text { to the left of the description column. } \\
\text { If known, write the farm name and address on the chain-of-custody form } \\
\text { to the left of the description column. } \\
\text { Weigh the sample (total weight of all bags) and record the weight and } \\
\text { sampling date on the chain-of-custody form. This can be done in the field } \\
\text { or at PNNL. A sample weight should be at least as large as the minimum } \\
\text { sample weight indicated on the chain-of-custody form. } \\
\text { Write the date on the sample label, along with the actual sample size if it } \\
\text { differs from the sample size printed on the label. } \\
\text { Place the bagged sample into another bag (double bag) and put the sample } \\
\text { label between the bags, making sure that the label is readable through the } \\
\text { side of the outside bag. It is not necessary to remove the paper from the } \\
\text { back (sticky portion) of the label. } \\
\text { collection task leader. If the grower does not supply a receipt, the SESP } \\
\text { sample collector should create a receipt. }\end{array}$ \\
\hline $\begin{array}{l}\text { COMPLETING } \\
\text { CHAIN-OF- } \\
\text { CUSTODY FORMS }\end{array}$ & $\begin{array}{l}\text { See Section 8.1, Chain-of-Custody Forms, for procedures for completing } \\
\text { chain-of-custody forms. }\end{array}$ \\
\hline
\end{tabular}


SUBMITTING SAMPLES FOR ANALYSIS
Deliver the samples to the appropriate analytical laboratory as soon as possible after collection. If samples cannot be delivered the day they are collected, store them in a refrigerator overnight. See Section 8.1, Chainof-Custody Forms, for procedures for submitting samples to an analytical laboratory.

DOH and FDA samples are generally archived in a locked or secure freezer at PNNL before they are handed off or mailed to the appropriate agency. 
Table 6.2.1. Instructions for Collecting Crop Samples

\begin{tabular}{|l|l|}
\hline \multicolumn{1}{|c|}{ Sample Type } & \multicolumn{1}{c|}{ Instructions } \\
\hline Fruit & $\begin{array}{l}\text { Collect fresh, ripe fruit. Samples should not contain } \\
\text { dried or spoiled fruit. Samples can be collected from } \\
\text { an orchard or vineyard or from a market or vendor if } \\
\text { the source (field/vineyard) location is known. }\end{array}$ \\
\hline Alfalfa & $\begin{array}{l}\text { Use grass clippers or pruning shears to collect } \\
\text { samples of uncut alfalfa. Freshly bailed alfalfa is } \\
\text { acceptable if it's available and its source location is } \\
\text { known. }\end{array}$ \\
\hline Leafy vegetables & $\begin{array}{l}\text { Collect only edible portions, do not include roots or } \\
\text { dirt. Samples may consist of one, or a mixture of } \\
\text { any of the following: leaf lettuce, spinach, mustard } \\
\text { greens, turnip greens, beet greens, cabbage leaves } \\
\text { (not the head), or kale. }\end{array}$ \\
\hline Vegetables & $\begin{array}{l}\text { Collect fresh, ripe vegetables. Samples can be } \\
\text { collected from fields or from a roadside market or } \\
\text { vendor if the location of the source field is known. } \\
\text { Rinse off all dirt with potable water. }\end{array}$ \\
\hline
\end{tabular}




\subsection{WINE SAMPLES}

\begin{tabular}{|c|c|}
\hline INTRODUCTION & $\begin{array}{l}\text { Samples of wines made from grapes grown adjacent to and downwind of } \\
\text { the Hanford Site are collected to monitor for radionuclides originating } \\
\text { from the Hanford Site. Wines made from grapes grown in vineyards } \\
\text { located upwind of the site are also collected and analyzed for comparison. }\end{array}$ \\
\hline $\begin{array}{l}\text { MATERIALS } \\
\text { NEEDED }\end{array}$ & $\begin{array}{l}\text { The following materials may be needed to collect wine samples: } \\
\text { - Sample containers. } \\
\text { - Marking pen. } \\
\text { - Chain-of-custody forms and the daily trip log report. } \\
\text { - } \text { Sample labels. } \\
\text { - Gunnel. } \\
\text { - Global positioning system (GPS) instrument. } \\
\text { - Cash to pay for products. }\end{array}$ \\
\hline $\begin{array}{l}\text { SAMPLE } \\
\text { COLLECTION }\end{array}$ & $\begin{array}{l}\text { Cash for wine purchases can be obtained from the sample collection task } \\
\text { leader. } \\
\text { The sample collection task leader will contact the wineries and make } \\
\text { arrangements for sample collections. Sampled wines must be produced } \\
\text { from grapes grown in vineyards in the area of interest and harvested during } \\
\text { the current sampling year. } \\
\text { Samples are generally obtained from bulk tanks or barrels. We normally } \\
\text { supply the containers, winery personnel usually fill them. The amount of } \\
\text { wine purchased should be at least as large as the sum of the minimum } \\
\text { required volumes indicated on the chain-of-custody forms. }\end{array}$ \\
\hline
\end{tabular}

\begin{tabular}{|c|c|c|}
\hline $\begin{array}{r}\text { Date } \\
1 / 26 / 2007\end{array}$ & Proiet Managey 1/26/2007 & QA Services \\
\hline $\begin{array}{l}\text { Technical Reviewer } \\
\text { OE Buare }\end{array}$ & & Revision No. 5 \\
\hline
\end{tabular}


White wine and red wine samples should be collected from each sampling area (i.e., Pasco, Yakima, Mattawa). When possible, both the red and the white wine samples will be collected from the same winery. However, it is sometimes necessary to obtain the red and white wines from separate wineries.

At the time of collection, the SESP sample collection person must verify the production year for the wine and the vineyard location for grapes used to make the wine. This should be done before the sample containers are filled. If the wine is not from the current year and/or was not made from grapes grown in the collection area, contact the sample collection task leader or data management task leader for instructions.

After the sample containers are filled, write the sampling date on the sample label, along with the actual sample volume if it differs from the sample volume printed on the label. The sample volume should be at least as large as the minimum sample volume indicated on the chain-of-custody form.

Do not "eyeball” the sample volumes. Sample volumes must be measured.

Attach the sample label to the sample container. Use clear tape if necessary.

Write the sampling date and sample volume in the appropriate locations on the chain-of-custody form.

Write the winery name, vineyard name (if there is one), and name of the wine grape on the chain-of-custody form in the description column.

Find out the location of the vineyard (or vineyards) from the winery personnel, then go to the vineyard and obtain GPS coordinates (see Section 8.5, Determining Geographic Positions Using a Global Positioning System [GPS] Instrument). Write the GPS coordinates (lat/long) on the chain-of-custody form in the description column.

In addition to SESP samples, samples may also be collected for the Washington State Department of Health (DOH).

Return all remaining cash, and receipts for all samples, to the sample collection task leader. If the winery does not supply a receipt, the SESP sample collector should create a receipt. All of the wine purchased from one winery can be accounted for on one receipt. 


\begin{tabular}{|l|l|l|}
$\begin{array}{l}\text { COMPLETING } \\
\text { CHAIN-OF- } \\
\text { CUSTODY FORMS }\end{array}$ & $\begin{array}{l}\text { See Section 8.1, Chain-of-Custody Forms, for procedures for completing } \\
\text { chain-of-custody forms. }\end{array}$ \\
$\begin{array}{ll}\text { SUBMITTING } \\
\text { SAMPLES FOR }\end{array}$ & $\begin{array}{l}\text { Deliver the samples to the appropriate analytical laboratory as soon as } \\
\text { possible after collection. See Section 8.1, Chain-of-Custody Forms, for } \\
\text { procedures for submitting samples to an analytical laboratory. }\end{array}$ \\
$\begin{array}{l}\text { Samples collected for the Washington State Department of Health are } \\
\text { generally archived in a locked or secure cooler or freezer at PNNL until } \\
\text { they are relinquished to the state. }\end{array}$
\end{tabular}




\subsection{WILDLIFE SAMPLING}

\begin{tabular}{|c|c|}
\hline INTRODUCTION & $\begin{array}{l}\text { Wildlife samples are collected to: 1) assess the potential accumulation of } \\
\text { radionuclides, metals, and organic compounds in organisms living on or } \\
\text { near the Hanford Site, 2) determine potential doses to people who may } \\
\text { consume radiologically contaminated animal tissues, 3) verify the } \\
\text { effectiveness of onsite effluent and contaminant controls, and 4) provide } \\
\text { information about an animal's health. } \\
\text { Wildlife samples routinely collected by Hanford Site environmental } \\
\text { surveillance personnel include: } \\
\text { - Fish (Section 7.1). } \\
\text { - Waterfowl (Section 7.2). } \\
\text { - Rabbits (Section 7.3). } \\
\text { - Game birds (Section 7.4). } \\
\text { Otheer and Elk (Section 7.5). } \\
\text { manager. }\end{array}$ \\
\hline $\begin{array}{l}\text { FIREARMS } \\
\text { SAFETY }\end{array}$ & $\begin{array}{l}\text { No one will use a SESP firearm until they have taken the PNNL firearms } \\
\text { safety training course and have had hands-on training (firing range) with } \\
\text { the firearm being used. This training is an annual requirement. The } \\
\text { SESP firearms safety protocol will be read immediately prior to the use of } \\
\text { any PNNL firearm. See Sections } 8.4 \text { and } 9.3 \text { for additional information } \\
\text { about using firearms. }\end{array}$ \\
\hline $\begin{array}{l}\text { SAMPLING } \\
\text { REQUIREMENTS }\end{array}$ & $\begin{array}{l}\text { All sampling events must be coordinated with the SESP wildlife task } \\
\text { manager or delegate. } \\
\text { All members of the collection team must review and carry copies of the } \\
\text { required state and federal collection permits. If the permit includes a list } \\
\text { of authorized users, the name of the person conducting the sampling or } \\
\text { using a firearm must be on the list. }\end{array}$ \\
\hline
\end{tabular}

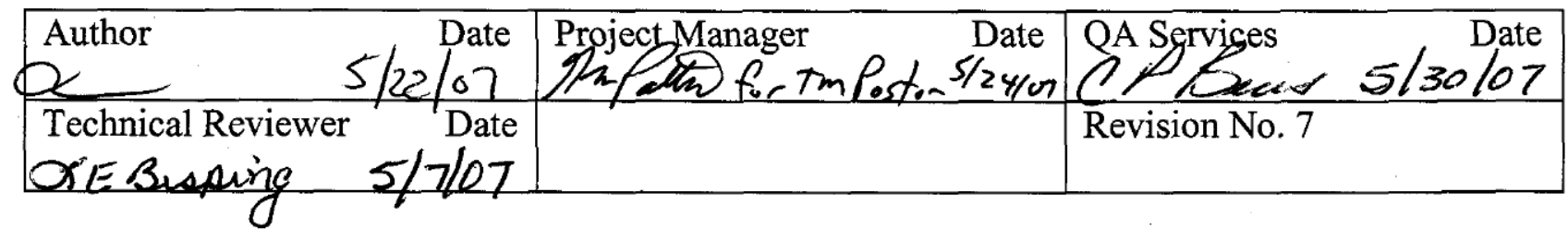


State and federal hunting rules do not necessarily apply to collections authorized by state and federal game collection permits. For example, when using a permit, samples can be collected out of season, birds can be shot on the ground, or on the water from a drifting boat, and animals of any sex can be taken. However, there are some restrictions associated with using the state and federal collection permits and these restrictions, which are outlined in the permits, must be honored. 


\subsection{FISH}

\begin{tabular}{|c|c|}
\hline INTRODUCTION & $\begin{array}{l}\text { Fish are collected from the Hanford Reach of the Columbia River to } \\
\text { monitor for selected radionuclides and metals that are known or suspected } \\
\text { to be present on the Hanford Site. Samples are also obtained at upriver or } \\
\text { distant locations to obtain background measurements. } \\
\text { Fish (carp, sucker, bass, and whitefish) may be collected using a boat- } \\
\text { mounted electrofishing unit, rod and reel, nets, or other sampling } \\
\text { techniques. The electrofisher must be operated under the supervision of a } \\
\text { trained biologist who can assist with species identifications and keep } \\
\text { track of the number of each species shocked during each electrofishing } \\
\text { event. A trained biologist must also be present when seine nets are used } \\
\text { to assure that the nets are deployed properly. }\end{array}$ \\
\hline $\begin{array}{l}\text { GENERAL } \\
\text { EQUIPMENT AND } \\
\text { SUPPLIES }\end{array}$ & $\begin{array}{l}\text { The following equipment and supplies may be needed when collecting } \\
\text { fish samples: } \\
\text { - } \quad \text { A cellular telephone. } \\
\text { - } \quad \text { A bolid state and federal game collection permits. } \\
\text { - An ice chest and ice. } \\
\text { - A fillet knife. } \\
\text { - Plastic bags. } \\
\text { - Tape. } \\
\text { - Sample labels and chain-of-custody form. } \\
\text { - A permanent marking pen. } \\
\text { - Sport fishing tackle (rods, reels, landing nets, bait or lures). } \\
\text { - Electrofishing equipment (see list below). }\end{array}$ \\
\hline
\end{tabular}

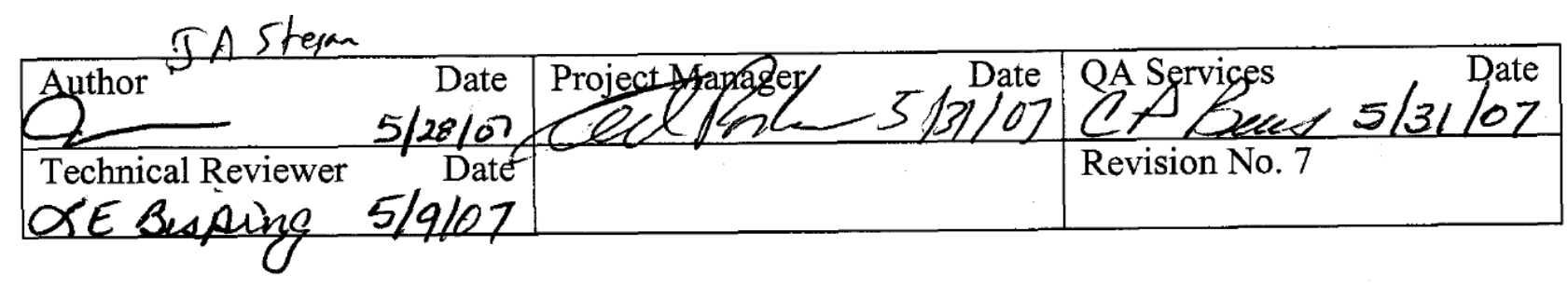




\begin{tabular}{|c|c|}
\hline & $\begin{array}{l}\text { - A global positioning system (GPS) instrument. } \\
\text { - } \text { A seine net. } \\
\text { - Boots for wading when seining. } \\
\text { - A depth finder (optional). } \\
\text { - A field notebook. }\end{array}$ \\
\hline $\begin{array}{l}\text { EQUIPMENT AND } \\
\text { SUPPLIES FOR } \\
\text { ELECTROFISHING }\end{array}$ & 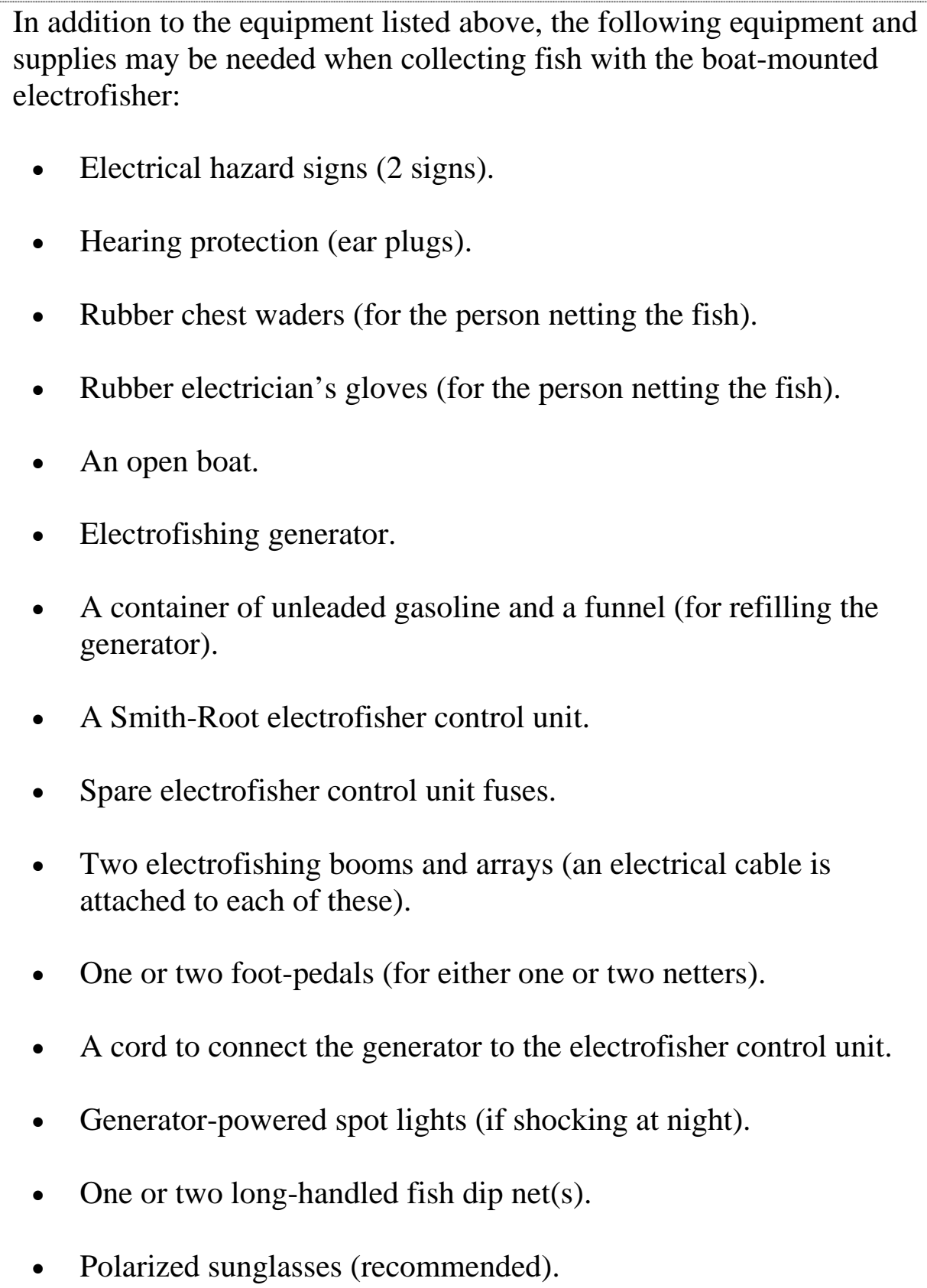 \\
\hline
\end{tabular}




\section{PRE-SAMPLING} PREPARATION

- Review Section 9.4, Operation of Electrofisher, and comply with its requirements.

- Review the applicable game collection permits and comply with their requirements and restrictions.

- Make sure all equipment is in good condition, i.e., no leaks in rubber gloves, no worn connection cords, fuses in generator are good, etc.

- Inventory the equipment to ensure there are no missing pieces.

- Make sure that all of the equipment works properly.

- Check the fuel levels in the truck, boat, generator, and generator gas container. Replenish the fuel if necessary.

- The boat operator must file a float plan prior to leaving for the field (refer to Section 9.1).

SETTING UP THE SHOCKING EQUIPMENT
The three basic components of the boat electrofisher include a generator, control unit, and booms and arrays (see Figure 7.1.1).

- Attach the anode/cathode (boom set) cord to the two-pin circular socket input located near the bottom of the electrofisher control unit.

- Attach the safety foot pedal (for either one or two netters) to the four-pin circular socket input located next to the anode/cathode input. An electrical current is produced when the pedal is depressed.

- Plug one end of the power cord into the three-pin circular socket input on the electrofisher control unit, and the other end into the four-prong 220 VAC input on the generator.

- Install the booms (anode/cathode) so that the arrays are secured to the gunwale and are dangling in the water on one side of the boat (usually on the side of the boat nearest the shore when the boat is facing downstream). The boom labeled "\#1" is positioned nearest the bow of the boat.

- Attach the ground wire clamps to the metal hull of the boat. 


\section{SETTING UP THE ELECTROFISHER CONTROL UNIT}

STARTING THE GENERATOR

ENERGIZING THE ELECTROFISHER CONTROL UNIT

- $\quad$ Set the "OUTPUT MODE" switch to 120 PPS DC (marked orange).

- $\quad$ Set the "PULSE WIDTH" switch to about 6 MS (marked orange).

- $\quad$ Set the "VOLTAGE SELECTOR" switch to 884 VDC (marked orange).

- $\quad$ Turn the "READY" key clockwise 1/4 turn (marked orange).

- Lift the red cover on the "EMERGENCY SHUTDOWN," and move the switch handle to the "ON" (orange side) position.

- Turn the generator switch to "ON," and pull-start the generator.

NOTE: It may be necessary to choke the generator to get it started. To choke the generator, move the choke lever (gray color) toward the pull-start handle. Once the generator has started, move the choke lever back to its original position.

CAUTION: To avoid damage to the electrofisher control unit, it must only be energized or de-energized when the generator is running.

- To energize, flip the "INPUT POWER" switch of the electrofisher control unit to "ON." The power indicator light should be on.

- To de-energize, flip the "INPUT POWER" switch to "OFF."

COLLECTING

WITH THE ELECTROFISHER
CAUTION: Do not attempt to electrofish if there are any animals or people in or near the water within 100 meters of the boat.

NOTE: When the generator and electrofisher control unit are operating and the foot pedal is depressed, an electrical current will flow from one boom (anode) through the water to the other boom (cathode).

IMPORTANT: The person netting the fish must control the foot pedal. If two people are netting fish, each must have a foot pedal.

- Ensure that the timer on the electrofisher control unit has been reset to " 0. "

- $\quad$ Record the GPS coordinates at the beginning of each sampling event. 
- With the motor running, float along the shoreline with the boat pointed downstream and the booms pointed toward the riverbank.

NOTE: In sloughs and backwater areas where there are usually no currents to contend with, shocking can be conducted in any direction.

- Shock in water depths ranging from 4 to 10 feet.

NOTE: The biologist (who is usually driving the boat) must keep a physical or mental tally of the number of fish of each species stunned whether or not they were captured. This tally must be recorded in a notebook at the end of the shocking event. This is a permit requirement.

- Use the foot pedal to intermittently deactivate the electrofisher. When two people are netting, one netter should continually depress one foot-pedal.

NOTE: Do not deactivate the electrofisher when attempting to net a stunned fish.

CAUTION: Be careful not to hit the boat operator or other people in the boat with the net handle.

- If possible, bag each fish and label (using the marking pen) each bag with the TAG ID, sampling date, and sampling location.

NOTE: The TAG ID can be found in the comment column on the chain-of-custody form.

- If possible, use the GPS instrument to determine the location coordinates for each fish collected. These coordinates should be recorded in the field notebook at the time of collection, along with the TAG ID of the fish.

- $\quad$ Place the bagged fish in an ice chest with ice.

NOTE: If may not be possible to obtain GPS coordinates and bag and label each fish as they are collected during a sampling event. In this case, put the collected fish into an ice chest or container and bag and label the fish at the end of the sampling event. 


\begin{tabular}{|c|c|}
\hline & 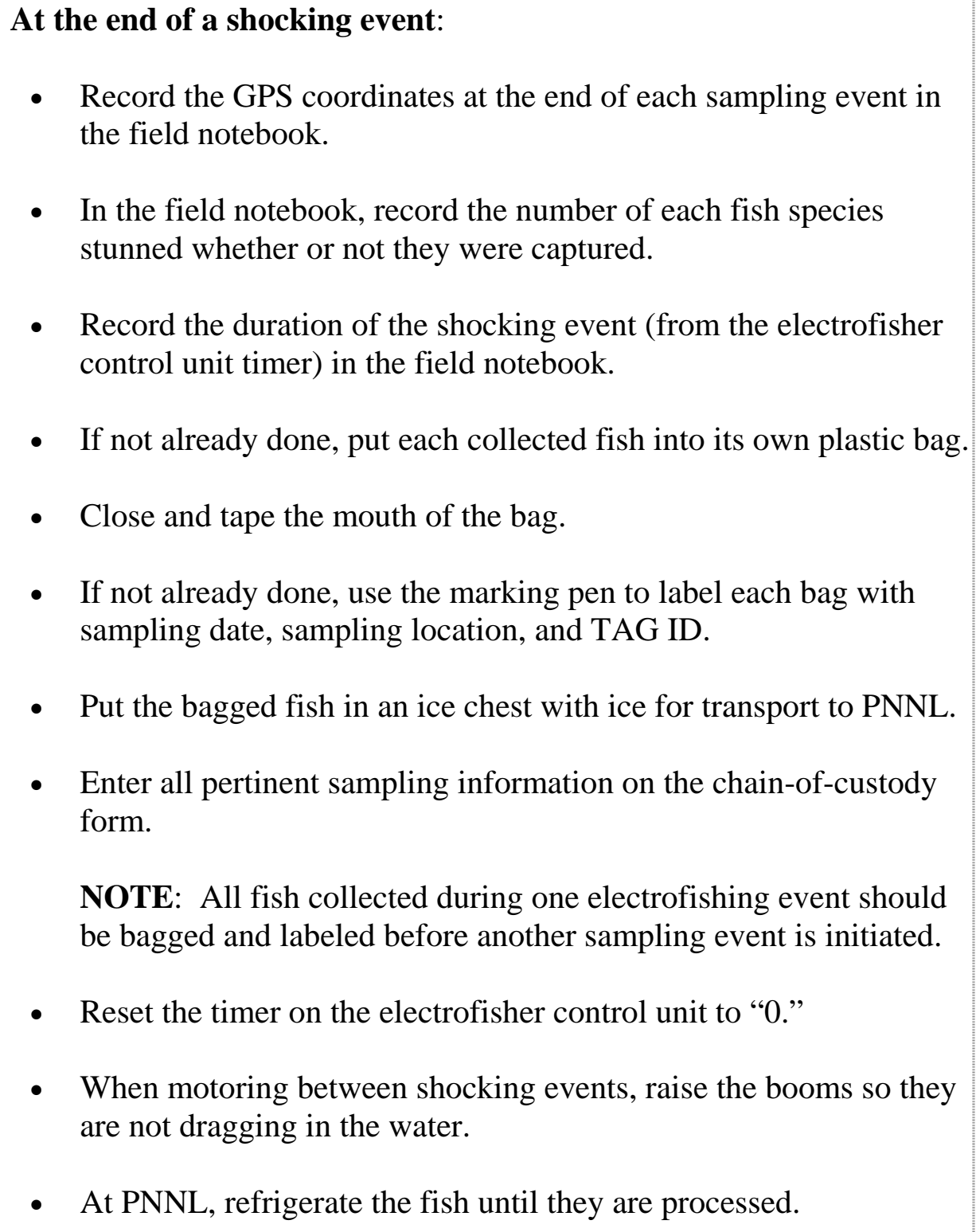 \\
\hline $\begin{array}{l}\text { COLLECTING } \\
\text { WITH ROD AND } \\
\text { REEL OR NETS }\end{array}$ & $\begin{array}{l}\text { Rod and reel equipment and techniques differ from one species to } \\
\text { another and one collection location to another and are not discussed } \\
\text { here. } \\
\text { NOTE: Personnel fishing with lures and baited hooks should be careful } \\
\text { to avoid embedding a hook in themselves or in others. } \\
\text { Netting techniques also vary by location and species and are not } \\
\text { discussed in these procedures. Instructions for using nets will be } \\
\text { provided on-the-job by the trained biologist assisting with collections. }\end{array}$ \\
\hline
\end{tabular}




\begin{tabular}{|c|c|}
\hline & 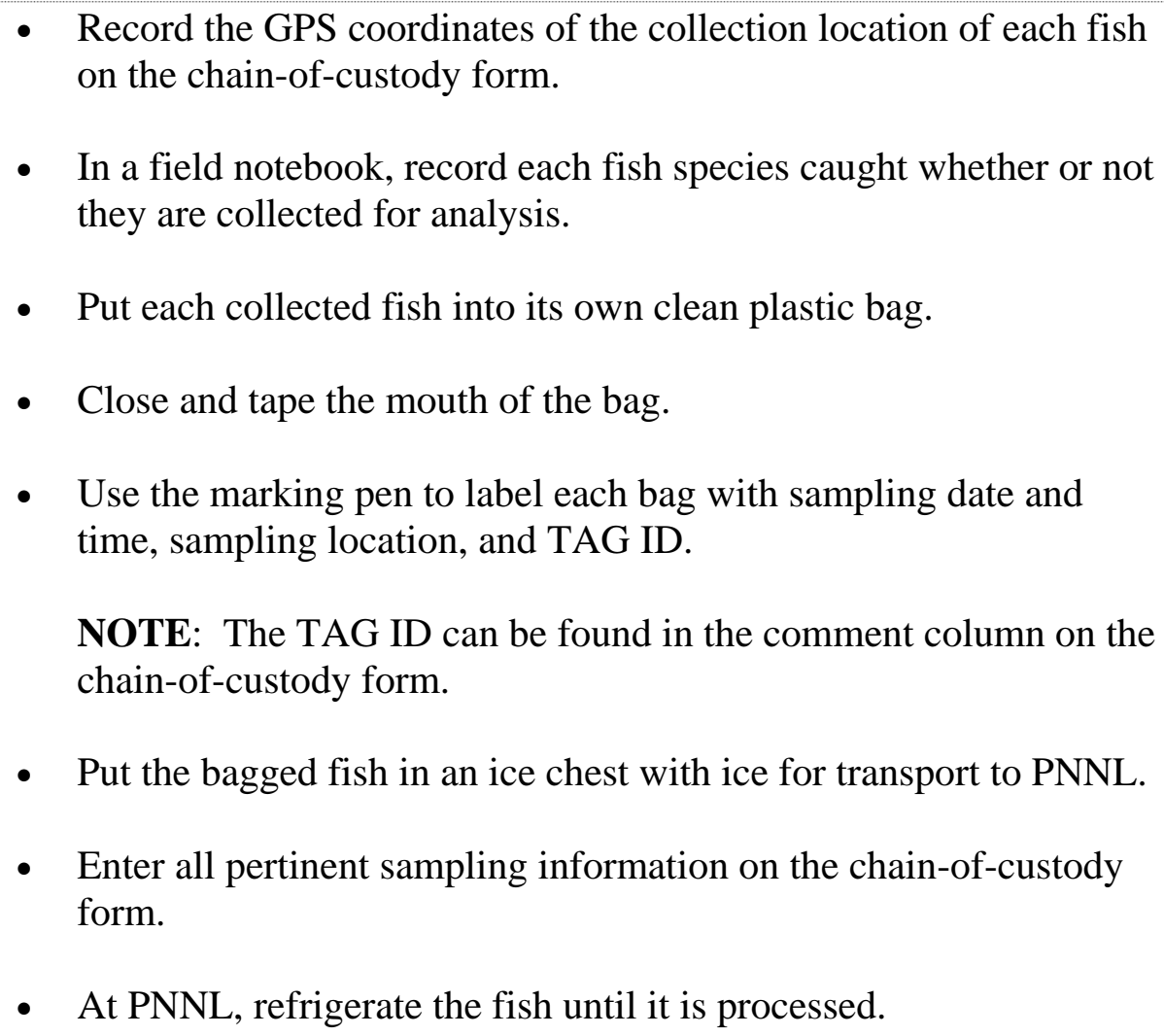 \\
\hline $\begin{array}{l}\text { EQUIPMENT } \\
\text { STORAGE }\end{array}$ & $\begin{array}{l}\text { - Clean and store all equipment properly so that it is ready for future } \\
\text { use. } \\
\text { - } \quad \text { Store all the electrofishing equipment together. } \\
\text { - Clean up and gas up the boat and vehicle. }\end{array}$ \\
\hline $\begin{array}{l}\text { HARVESTING } \\
\text { MUSCLE TISSUE } \\
\text { SAMPLES } \\
\text { (FILLETS) }\end{array}$ & $\begin{array}{l}\text { NOTE: Do not harvest fish tissues for radiological analyses until } \\
\text { the biological specialist has completed the collection of the liver } \\
\text { and/or other tissue for metals analyses. } \\
\text { - When a fish is removed from the refrigerator for processing, verify } \\
\text { that the TAG ID on the bag matches the TAG ID on the chain-of- } \\
\text { custody form. } \\
\text { - Place the fish on a clean surface. } \\
\text { - Remove the organs in the abdominal cavity of the fish. These are } \\
\text { waste materials and will be discarded. } \\
\text { Cut fillets from both sides of each fish and remove the skin. }\end{array}$ \\
\hline
\end{tabular}




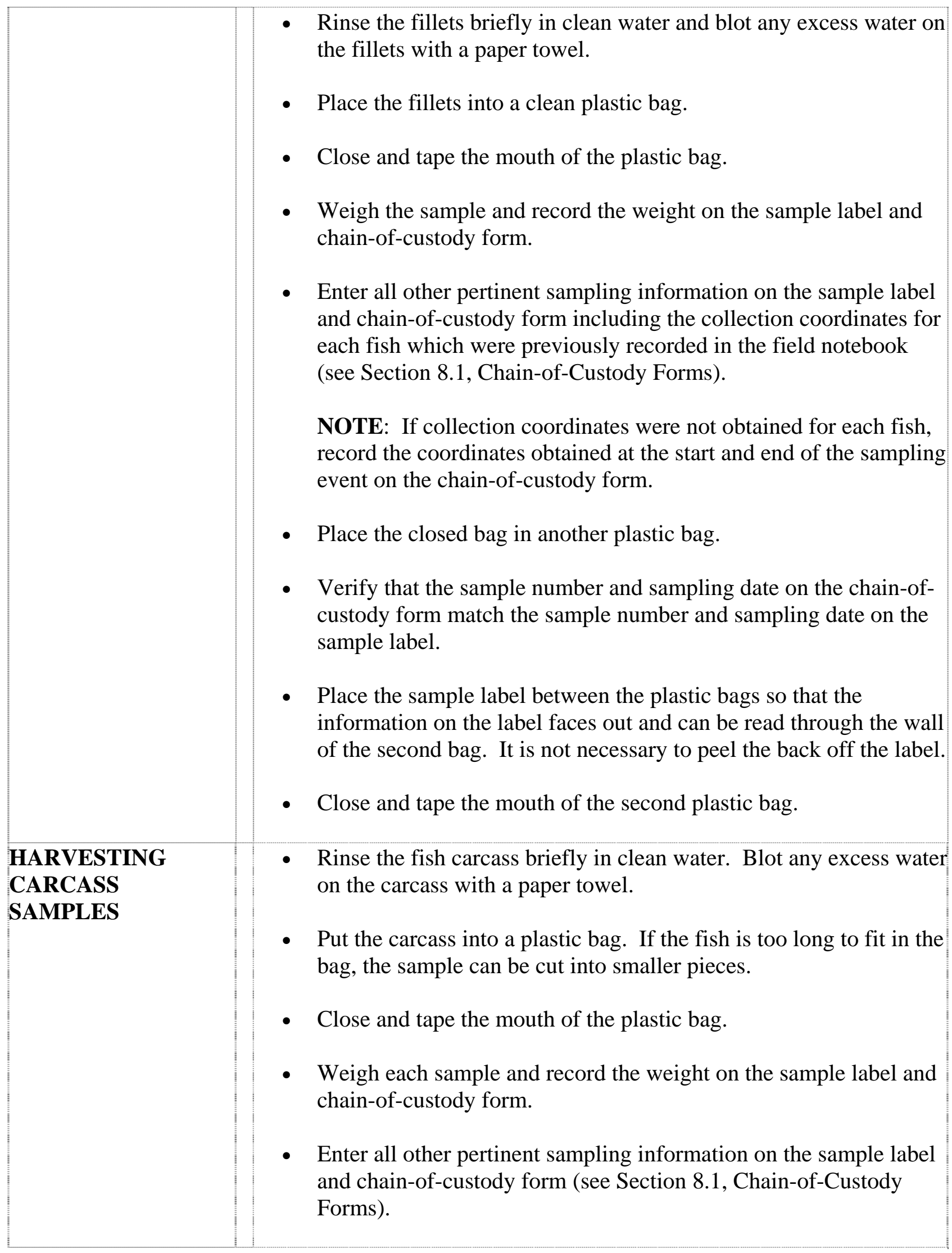




\begin{tabular}{|c|c|}
\hline & $\begin{array}{l}\text { - } \quad \text { Place the closed bag into another plastic bag. } \\
\text { custody form match the sample number and sampling date on the } \\
\text { sample label. } \\
\text { - } \quad \text { Place the label between the plastic bags so that the information on } \\
\text { the label faces out and can be read through the wall of the second } \\
\text { bag. It is not necessary to peel the back off the label. } \\
\text { - Close and tape the mouth of the second plastic bag. } \\
\text { - Put all excess tissues from all fish in plastic bags for disposal. One } \\
\text { bag may be sufficient for all tissues. } \\
\text { - Write "Excess fish parts," the general collection location, and the } \\
\text { current date on the bags. } \\
\text { - Store the bags in a freezer until the sample collection task leader } \\
\text { issues instructions for disposal. }\end{array}$ \\
\hline $\begin{array}{l}\text { FISH COLLECTED } \\
\text { FOR THE } \\
\text { WASHINGTON } \\
\text { STATE } \\
\text { DEPARTMENT OF } \\
\text { HEALTH }\end{array}$ & $\begin{array}{l}\text { Several fish are collected each year and provided to the Washington } \\
\text { State Department of Health. These fish should be bagged (whole), } \\
\text { labeled as described in COLLECTING WITH ROD AND REEL OR } \\
\text { NETS, and stored in a freezer at PNNL until they are relinquished to the } \\
\text { Department of Health (see Section } 8.1 \text { for relinquishing instructions). }\end{array}$ \\
\hline $\begin{array}{l}\text { COMPLETING } \\
\text { CHAIN OF } \\
\text { CUSTODY FORMS } \\
\text { AND SUBMITTING } \\
\text { SAMPLES FOR } \\
\text { ANALYSIS }\end{array}$ & $\begin{array}{l}\text { If samples cannot be submitted to an analytical laboratory on the day } \\
\text { they are collected or processed, store the samples in a freezer or } \\
\text { refrigerator. } \\
\text { See Section 8.1, Chain-of-Custody Forms, for further requirements for } \\
\text { completing chain-of-custody forms and submitting samples to an } \\
\text { analytical laboratory. }\end{array}$ \\
\hline
\end{tabular}




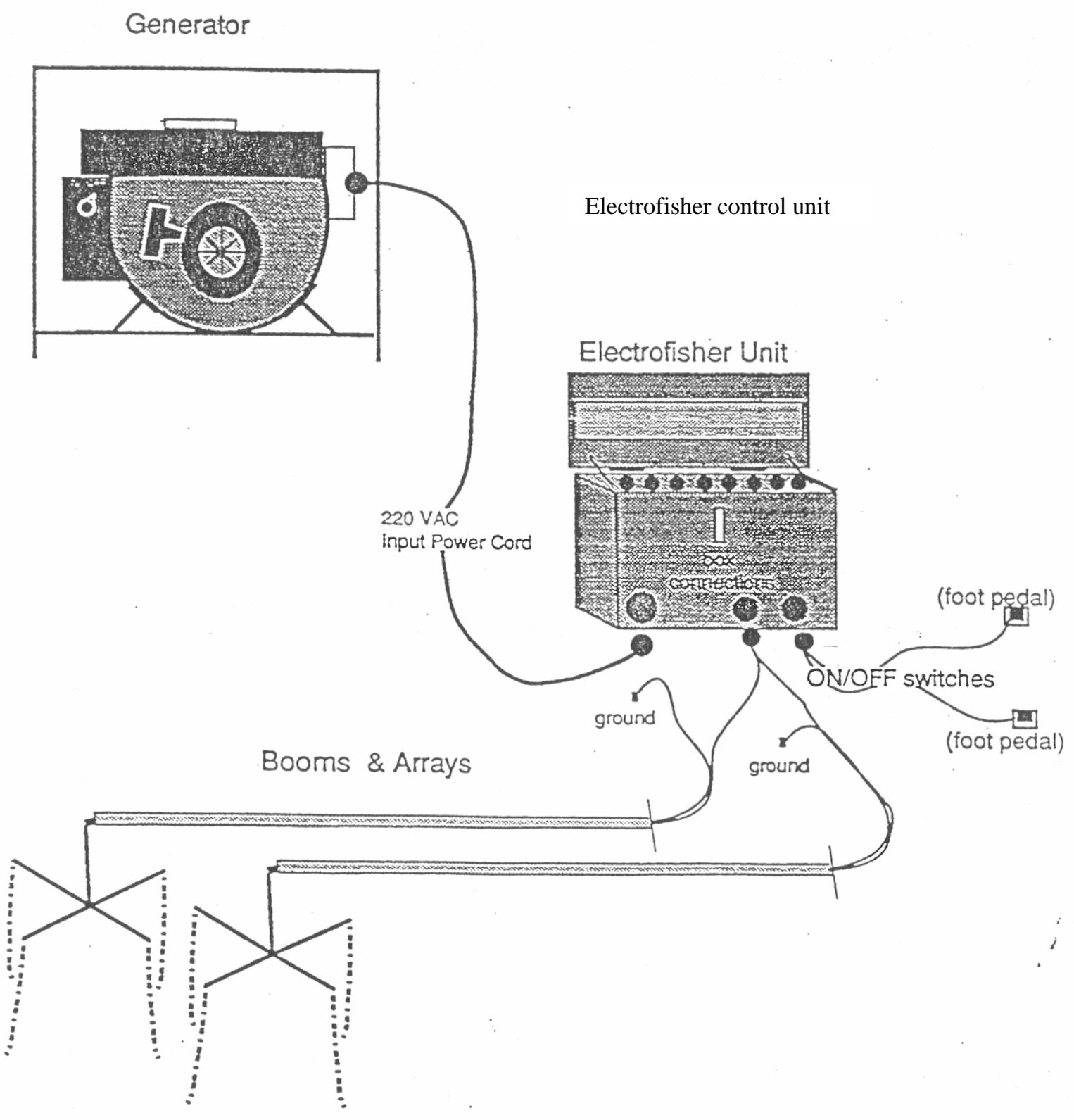

Figure 7.1.1. Electrofisher Components 


\subsection{WATERFOWL}

\section{INTRODUCTION \\ EQUIPMENT AND SUPPLIES}

Waterfowl are collected along the Hanford Reach of the Columbia River and at distant, background locations to monitor levels of radiological and chemical contaminants in tissues and/or organs.

The following equipment and supplies may be needed when collecting waterfowl samples:

- Cellular telephone.

- Valid game collection permits.

- A DOE prohibited articles pass for firearms and ammunition.

- A boat with proper signage (see collection permit for details).

- A shotgun or .22 caliber rifle and ammunition (stainless-steel shotgun pellets are preferred).

- $\quad$ Safety glasses.

- Hunter's orange clothing.

- Appropriate hearing protection.

- An ice chest and ice.

- A sharp knife or scalpel.

- Disposable rubber or plastic gloves.

- $\quad$ Plastic bags.

- $\quad$ Tape.

- Paper or cloth towels.

- Sample labels and chain-of-custody form.

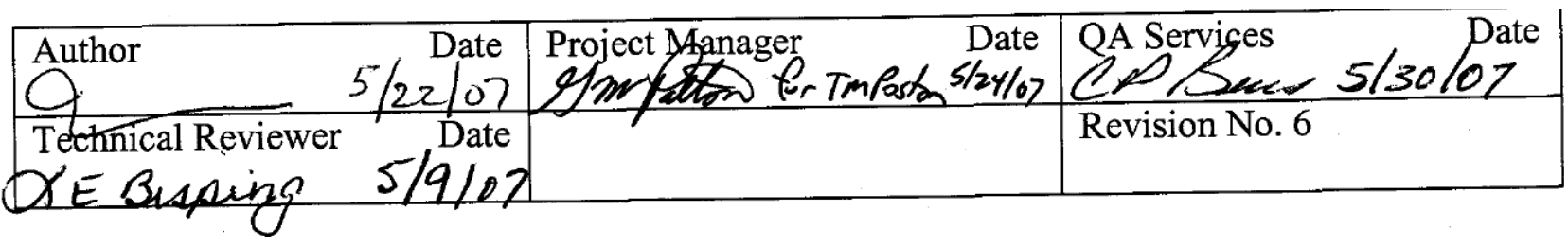




\begin{tabular}{|c|c|}
\hline & $\begin{array}{l}\text { - } \text { Bird identification handbook. } \\
\text { - A permanent marking pen. } \\
\text { - A cervical dislocation instrument and protective plate. } \\
\text { - A global positioning system (GPS) instrument. }\end{array}$ \\
\hline $\begin{array}{l}\text { PRE-SAMPLING } \\
\text { PREPARATION }\end{array}$ & $\begin{array}{l}\text { - If collecting with firearms, review Sections } 8.4 \text { and } 9.3 \text { and comply } \\
\text { with their requirements. } \\
\text { - Review the applicable game collection permits and comply with } \\
\text { their requirements and restrictions. } \\
\text { - Obtain a rifle and/or shotgun and ammunition from the SESP } \\
\text { firearms custodian. } \\
\text { - If appropriate, the boat operator must file a float plan prior to } \\
\text { leaving for the field (see Section 9.1). } \\
\text { - Notify the PNNL Operations Center and tell them where and when } \\
\text { the samples will be collected and how many people will be using } \\
\text { firearms. } \\
\text { - If sampling onsite, the sample collection task manager must notify } \\
\text { any site contractors who might have personnel working in or near } \\
\text { the collection area. } \\
\text { - If collecting on the site, notify the Hanford Patrol Operations } \\
\text { Center and tell them where and when the samples will be collected } \\
\text { and how many people will be using firearms. }\end{array}$ \\
\hline $\begin{array}{l}\text { SAMPLE } \\
\text { COLLECTION }\end{array}$ & $\begin{array}{l}\text { Waterfowl collections may be conducted from a boat or on land, } \\
\text { depending on the collection location. } \\
\text { - Birds on the ground or on the water can be collected. Birds do not } \\
\text { have to be flying. } \\
\text { - If a bird is wounded but, for one reason or another, can't be } \\
\text { collected, record the sampling location and species of the wounded } \\
\text { bird in a field notebook. } \\
\text { - If the bird is wounded and collected, euthanize the animal by } \\
\text { cervical dislocation. Slide the bird's neck into the slot of the } \\
\text { protection plate, and pinch its neck with the instrument. }\end{array}$ \\
\hline
\end{tabular}


- Put each collected bird into its own clean plastic bag.

- Close and tape the mouth of the bag.

- Using the marking pen, label each bag with sampling date, sampling location, and TAG ID.

NOTE: The TAG ID can be found in the comment column on the chain-of-custody form.

- Put the bird in an ice chest with ice for transport to PNNL.

- Use the GPS instrument to obtain the coordinates of the collection site and record the coordinates on the chain-of-custody form.

- Enter all other pertinent sampling information on the chain-ofcustody form.

- Notify the PNNL Operations Center when field collections are terminated.

- At PNNL, refrigerate the bird until it is processed.

HARVESTING MUSCLE TISSUE SAMPLES

\section{When harvesting muscle tissue from the bird:}

NOTE: Do not harvest tissues for radiological analyses until the biological specialist has completed the collection of liver and/or other tissue for metals analyses.

- Put on disposable gloves.

- Remove the bird from the refrigerator and make sure that the TAG ID on the bag matches the TAG ID on the chain-of-custody form.

- Place the bird on a clean surface to remove the breast muscle (skinless).

- Rinse the breast muscle briefly in clean water and blot the excess water with a paper towel.

- Weigh the breast muscle and record the weight on the sample label and chain-of-custody form. If the weight of the breast muscle is insufficient (as specified on the chain of custody form), add muscle tissue from the thighs.

- Put the muscle sample into a plastic bag. 


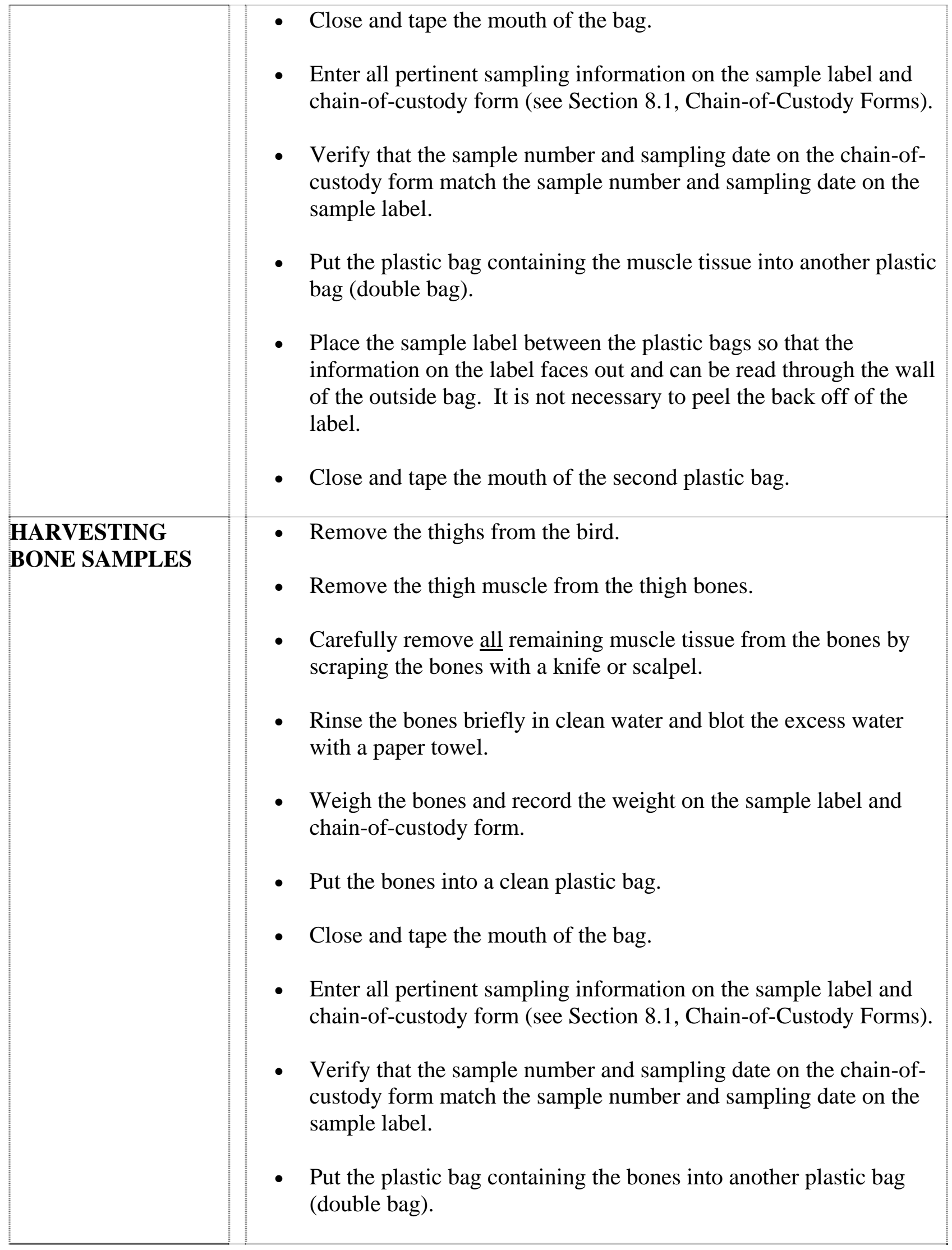


- Place the sample label between the plastic bags so that the information on the label faces out and can be read through the wall of the outside bag. It is not necessary to peel the back off of the label.

- Close and tape the mouth of the second plastic bag.

- Put all excess bird tissues from all birds in plastic bags for disposal. One bag may be sufficient for all tissues.

- Write "Excess bird parts," the current date, and the general collection location on the bags.

- Store the bags in a freezer until the sample collection task leader issues instructions for disposal.

If samples cannot be submitted to an analytical laboratory on the day they are collected or processed, store the samples in a freezer or refrigerator.

See Section 8.1, Chain-of-Custody Forms, for further requirements for completing chain-of-custody forms and submitting samples to an analytical laboratory. 


\subsection{RABBITS}

\begin{tabular}{|c|c|}
\hline INTRODUCTION & $\begin{array}{l}\text { Cottontail rabbits are collected onsite to monitor contaminant movement } \\
\text { and radionuclide uptake by small mammals in the vicinity of operational } \\
\text { areas, former waste disposal sites, and waste storage areas. Rabbits are } \\
\text { also obtained at offsite distant locations to obtain background } \\
\text { measurements. } \\
\text { Based on past surveillance and near field monitoring experience, it is } \\
\text { possible for rabbits to accumulate elevated concentrations of } \\
\text { radionuclides near the } 200 \text { Areas. Therefore, rabbit samples collected } \\
\text { near the 200-East and 200-West Areas will be surveyed for beta-gamma } \\
\text { activity before they are transported or processed. See Section } 8.3 \text {, } \\
\text { Radiological Surveys of Samples, if radiation is detected in a rabbit. }\end{array}$ \\
\hline $\begin{array}{l}\text { EQUIPMENT AND } \\
\text { SUPPLIES }\end{array}$ & $\begin{array}{l}\text { The following equipment and supplies may be needed when collecting } \\
\text { rabbit samples: } \\
\text { - Shotguns, .22 caliber rifle, and appropriate ammunition. } \\
\text { - Appropriate hearing protection. } \\
\text { - } \text { Rabbit traps (live traps). } \\
\text { - } \text { Bait for the traps. } \\
\text { - Safety glasses. } \\
\text { - An ice chest with ice. } \\
\text { - Sharp knife or scalpel. } \\
\text { - Disposable rubber or plastic gloves. } \\
\text { - Paper or cloth towels. } \\
\text { - Portable radiological survey instruments. } \\
\text { - Plastic bags. }\end{array}$ \\
\hline
\end{tabular}

\begin{tabular}{|c|c|c|}
\hline Author & Project Manager 51 Date & 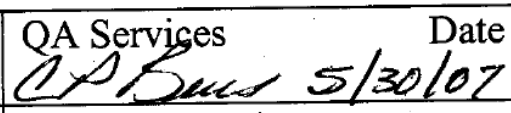 \\
\hline $\begin{array}{l}\text { Technical Reviewer } \text { Date } \\
\text { DE Busing 5/9107 }\end{array}$ & & Revision No. 4 \\
\hline
\end{tabular}




\begin{tabular}{|c|c|}
\hline & $\begin{array}{l}\text { - Tape. } \\
\text { - } \text { Valid game collection permits. } \\
\text { - Sample labels and chain-of-custody form. } \\
\text { - A permanent marking pen. } \\
\text { - A DOE prohibited articles pass for firearms and ammunition. } \\
\text { - A cellular telephone. } \\
\text { - A global positioning system (GPS) instrument. }\end{array}$ \\
\hline $\begin{array}{l}\text { PRE-SAMPLING } \\
\text { PREPARATION }\end{array}$ & $\begin{array}{l}\text { - Review and adhere to all requirements listed in the applicable game } \\
\text { collection permit(s). } \\
\text { - Collect the routine samples by using traps or a firearm, according to } \\
\text { the procedures outlined below. } \\
\text { - } \quad \text { Review Sections } 8.4 \text { and } 9.3 \text { and comply with their requirements. } \\
\text { - Purchase or obtain bait for the traps. If needed, cash for purchases } \\
\text { can be obtained from the sample collection task manager. Unused } \\
\text { cash and all receipts must be returned to the sample collection task } \\
\text { manager. } \\
\text { - Obtain a rifle and/or shotgun and ammunition from the SESP } \\
\text { firearms custodian. } \\
\text { - If using firearms, notify the PNNL Operations Center and tell them } \\
\text { where and when the samples will be collected and how many people } \\
\text { will be using firearms. } \\
\text { - If using firearms on the site, the sample collection task manager } \\
\text { must notify any site contractors who might have personnel working } \\
\text { in or near the collection area. } \\
\text { - If using firearms on the site, notify the Hanford Patrol Operations } \\
\text { Center and tell them where and when the samples will be collected } \\
\text { and how many people will be using firearms. }\end{array}$ \\
\hline
\end{tabular}


COLLECTING WITH FIREARMS AND SPOTLIGHTS AFTER DARK
- At sunset (while it's still light), drive through the selected sampling area to assure the area is clear of people.

- $\quad$ Spotlighting should begin immediately after dark.

- Spotlighting is a two person operation: One person operates the vehicle and the other person operates the spotlight and uses the firearm.

- $\quad$ Search for rabbits with the spotlight while slowly driving the roads within the sampling area.

IMPORTANT: Jackrabbits should not be collected unless the wildlife task manager issues instructions to do so. Collect cottontail rabbits only.

- When a rabbit is spotted, stop the vehicle while keeping the light positioned on the rabbit.

- The shooter must exit the vehicle with the firearm and the appropriate ammunition.

CAUTION: DO NOT EXIT FROM A MOVING VEHICLE. The shooter must load and discharge the firearm outside of the vehicle.

- After shooting, all spent shells should be retrieved and all live ammunition must be removed from the firearm before returning it to the vehicle.

- Do a radiation survey (beta-gamma) of each rabbit collected near the 200 Areas.

- If radiation above background levels is detected, refer to Section 8.3 for guidance.

- Do not transport or process a rabbit that contains radiation at levels above background.

- If no radiation is detected, put the rabbit into a plastic bag.

- Close and tape the mouth of the plastic bag.

- $\quad$ Use the marking pen to label the bag with sampling date, species name, sampling location, and TAG ID.

NOTE: The TAG ID can be found in the comment column on the chain-of-custody form. 


\begin{tabular}{|c|c|}
\hline & 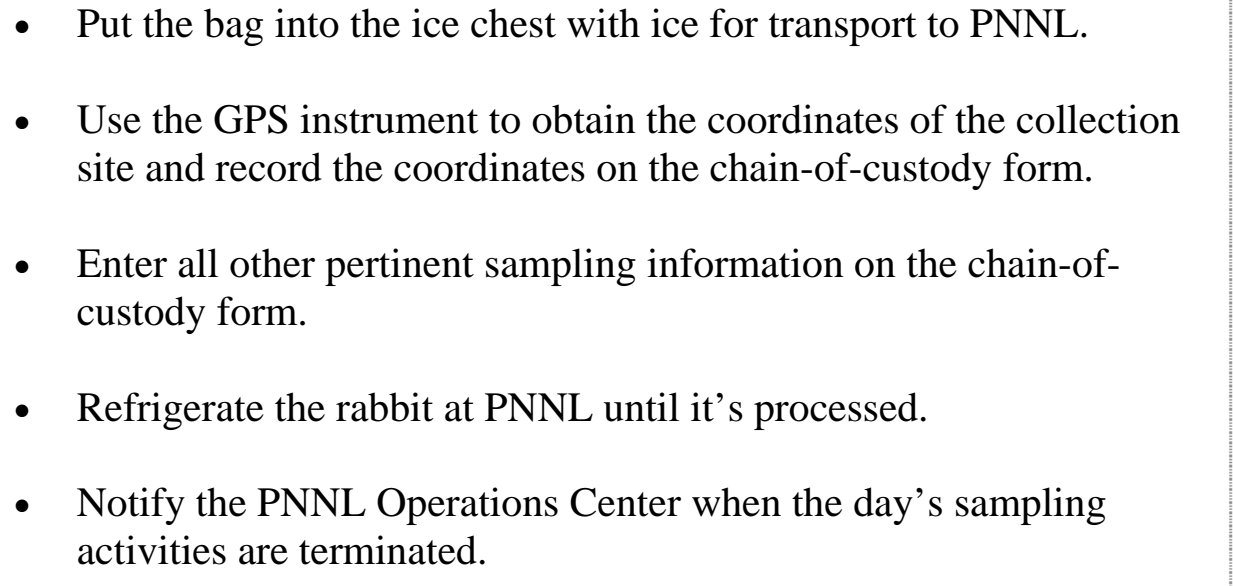 \\
\hline $\begin{array}{l}\text { IDENTIFYING A } \\
\text { TRAPPING } \\
\text { LOCATION AND } \\
\text { DEPLOYING THE } \\
\text { TRAPS }\end{array}$ & $\begin{array}{l}\text { - Verify that a "DO NOT TAMPER WITH" tag is affixed to all traps } \\
\text { prior to their deployment. } \\
\text { - Verify that a PNNL identity tag and contact phone number are } \\
\text { affixed to all traps prior to deployment. } \\
\text { - Prior to deploying traps, look for locations within the designated } \\
\text { trapping area that are heavily used by rabbits. Cottontails will } \\
\text { usually concentrate in shady areas around brush patches, rock piles, } \\
\text { or along the riverbank. Fresh tracks and rabbit pellets are helpful } \\
\text { indicators of rabbit activity. } \\
\text { NOTE: Rabbit trapping locations may be identified by the wildlife } \\
\text { task manager or a trained biologist prior to trap deployment. } \\
\text { If possible, place unset traps at the chosen trapping locations one or } \\
\text { two days prior to the collection period. This gives the rabbits time to } \\
\text { become “comfortable" with the traps. } \\
\text { Place the traps near, but not directly on, a rabbit pathway. } \\
\text { - Hide the trap, if possible. Tuck it into a nearby debris pile or place it } \\
\text { under the surrounding vegetation. Make sure the trap opening is not } \\
\text { blocked or hidden from sight and is generally facing the rabbit } \\
\text { pathway. } \\
\text { should be at least } 15 \text { yards apart. }\end{array}$ \\
\hline $\begin{array}{l}\text { BAITING THE } \\
\text { TRAPS }\end{array}$ & $\begin{array}{l}\text { - If possible, bait the traps one or two hours before sunset. If this is } \\
\text { not possible, bait the traps as late in the afternoon as is possible. } \\
\text { - Bait the traps with a combination of lettuce and sliced and shredded } \\
\text { carrots and apples. }\end{array}$ \\
\hline
\end{tabular}




\begin{tabular}{|c|c|}
\hline & $\begin{array}{l}\text { - Break the lettuce into pieces and slice the carrots and apples into } \\
\text { pieces about } 1 \text { inch long and } 0.5 \text { inch thick. } \\
\text { - Use } 4 \text { or } 5 \text { cups of bait per trap. } \\
\text { - The bait should be placed on and around the pan in the center of the } \\
\text { cage. }\end{array}$ \\
\hline $\begin{array}{l}\text { SETTING THE } \\
\text { TRAPS }\end{array}$ & 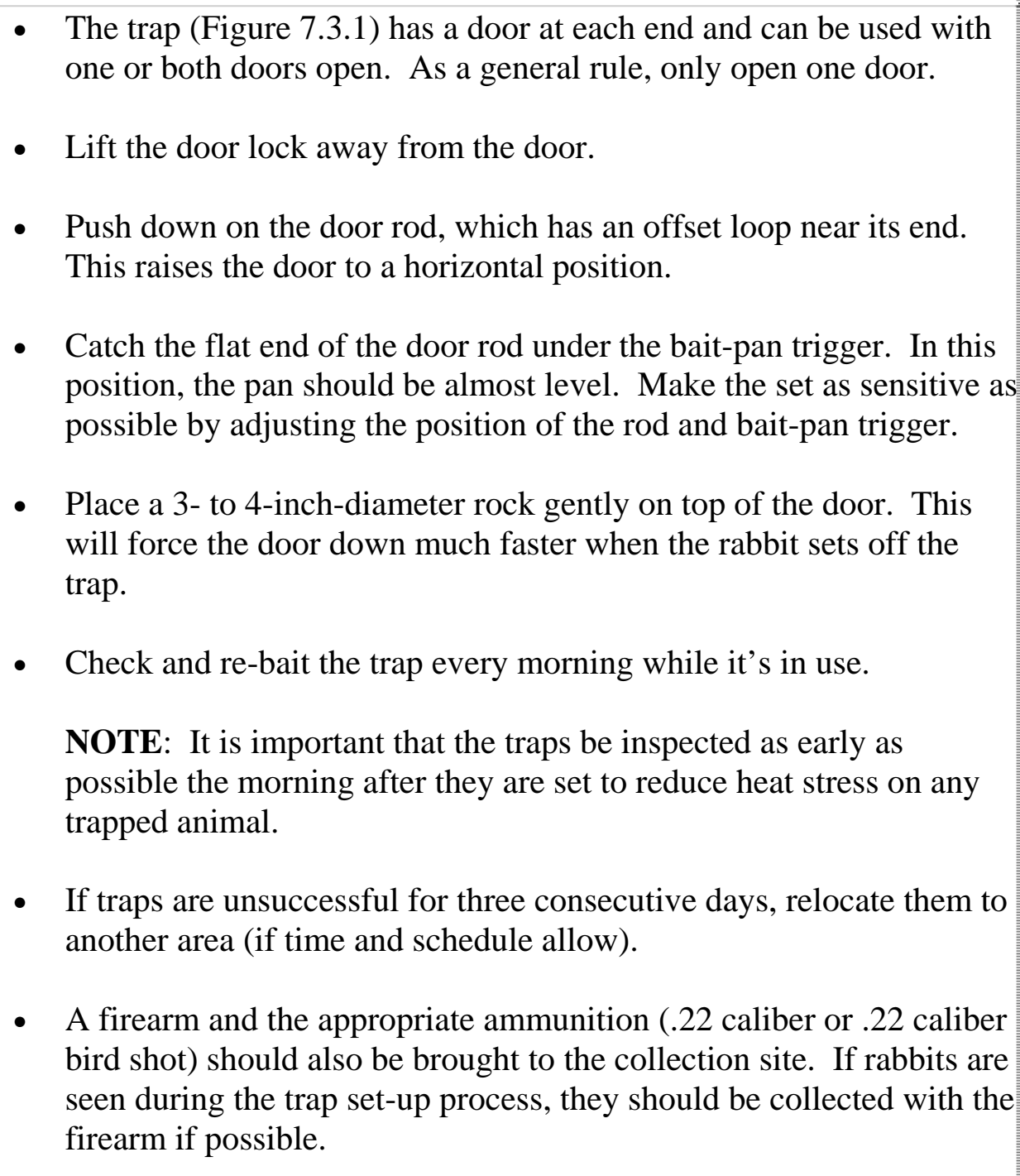 \\
\hline $\begin{array}{l}\text { COLLECTING } \\
\text { RABBITS FROM } \\
\text { TRAPS }\end{array}$ & $\begin{array}{l}\text { - Inspect the trap each morning following deployment. } \\
\text { - If the trap is empty, either close the trap until late afternoon when it } \\
\text { can be reset, leave the trap open and baited (only on a cool day), or } \\
\text { pick up the trap to return it to storage or to redeploy it elsewhere. } \\
\text { - If there is a rabbit in the trap, determine if it is a Jackrabbit or a } \\
\text { cottontail. Jackrabbits should be released (currently Jackrabbit } \\
\text { numbers on the site are low) and cottontails should be collected. }\end{array}$ \\
\hline
\end{tabular}


- Shoot the rabbit in the trap with a .22 caliber rifle loaded with bird shot. Aim just behind the rabbit's ear, with the barrel no farther than 4 inches away.

IMPORTANT: If the collector is working alone, for safety reasons he/she must contact the PNNL Operations Center prior to discharging the firearm and again immediately after discharging the firearm to confirm that he/she is unhurt.

- Do a radiation survey (beta-gamma) of each rabbit collected near the 200 Areas.

- $\quad$ If radiation above background levels is detected, refer to Section 8.3 for guidance.

- Do not transport or process a rabbit that contains radiation at levels above background.

- If no radiation is detected, put the rabbit into a plastic bag.

- $\quad$ Close and tape the mouth of the plastic bag.

- $\quad$ Use the marking pen to label the bag with sampling date, species name, sampling location, and TAG ID.

NOTE: The TAG ID can be found in the comment column on the chain-of-custody form.

- $\quad$ Put the bag into the ice chest with ice for transport to PNNL.

- Use the GPS instrument to obtain the coordinates of the collection site.

- Record the GPS coordinates on the chain-of-custody form.

- Enter all other pertinent sampling information on the chain-ofcustody form.

- Notify the PNNL Operations Center when collection activities are terminated.

- At PNNL, refrigerate the rabbit until it is processed. 
HARVESTING MUSCLE TISSUE SAMPLES
NOTE: Do not harvest muscle tissue for radiological analyses until the biological specialist has completed the collection of the liver and/or other tissue for metals analyses.

- Remove the rabbit from the refrigerator and make sure that the TAG ID on the bag matches the TAG ID on the chain-of-custody form.

- $\quad$ Place the rabbit on a clean surface for processing.

- Put on disposable gloves.

- $\quad$ Skin and remove the hind legs (excluding the feet).

CAUTION: Do not contaminate the samples with dirt, hair, gastrointestinal (GI) tract contents or any other foreign material.

- Remove the muscle tissue from both legs.

- $\quad$ Rinse the muscle tissue briefly with clean water and blot the excess water with a paper towel.

- Put the muscle tissue into a clean plastic bag.

- Weigh the sample and record the weight on the sample label and chain-of-custody form.

- $\quad$ Close and tape the mouth of the plastic bag.

- Enter all pertinent sampling information on the sample label and chain-of-custody form (see Section 8.1, Chain-of-Custody Forms).

- Verify that the sample number and sampling date on the chain-ofcustody form match the sample number and sampling date on the sample label.

- Put the plastic bag containing the muscle sample into another plastic bag (double bag).

- Place the sample label between the plastic bags so that the information on the label faces out and can be read through the wall of the outside bag. It is not necessary to peel the back off of the label.

- $\quad$ Close and tape the mouth of the second plastic bag. 
HARVESTING BONE SAMPLES

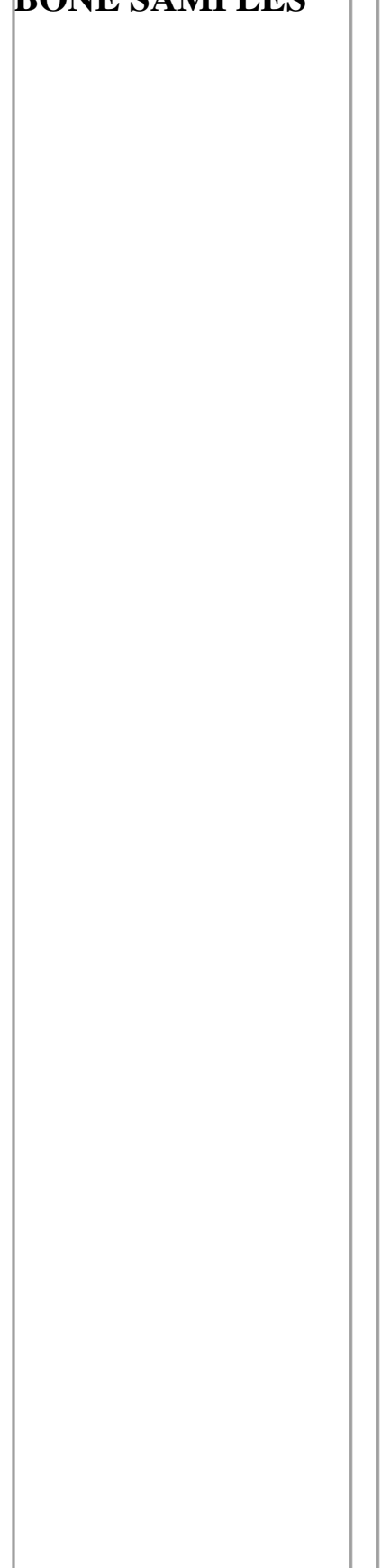

RABBITS

COLLECTED FOR

THE

WASHINGTON

STATE

DEPARTMENT OF

HEALTH
- Carefully scrape all remaining muscle tissue from the leg bones with a knife or scalpel.

- $\quad$ Rinse the leg bones briefly with clean water and blot the excess water with a paper towel.

- $\quad$ Put the bones into a plastic bag.

- Weigh the bones and record the weight on the sample label and chain-of-custody form.

- $\quad$ Close and tape the mouth of the plastic bag.

- Enter all pertinent sampling information on the sample label and chain-of-custody form (see Section 8.1, Chain-of-Custody Forms).

- Verify that the sample number and sampling date on the chain-ofcustody form match the sample number and sampling date on the sample label.

- $\quad$ Put the plastic bag containing the bones into another plastic bag (double bag).

- Place the sample label between the plastic bags so that the information on the label faces out and can be read through the wall of the outside bag. It is not necessary to peel the back off of the label.

- $\quad$ Close and tape the mouth of the second plastic bag.

- Put all excess tissues from all rabbits in plastic bags for disposal. One bag may be sufficient for all tissues.

- Write "Excess rabbit parts” and the current date on the bags.

- $\quad$ Store the bags in a freezer until the sample collection task leader issues instructions for disposal.

Rabbits may be collected and provided to the Washington State Department of Health. These rabbits should be bagged (whole), labeled as described above, and stored in a freezer at PNNL until they are relinquished to the Department of Health (see Section 8.1 for relinquishing instructions). 
COMPLETING CHAIN OF CUSTODY FORMS AND SUBMITTING SAMPLES FOR ANALYSES
If samples cannot be submitted to an analytical laboratory on the day they are collected or processed, store the samples in a freezer or refrigerator.

See Section 8.1, Chain-of-Custody Forms, for further requirements for completing chain-of-custody forms and submitting samples to an analytical laboratory. 


\section{TRAP PARTS}

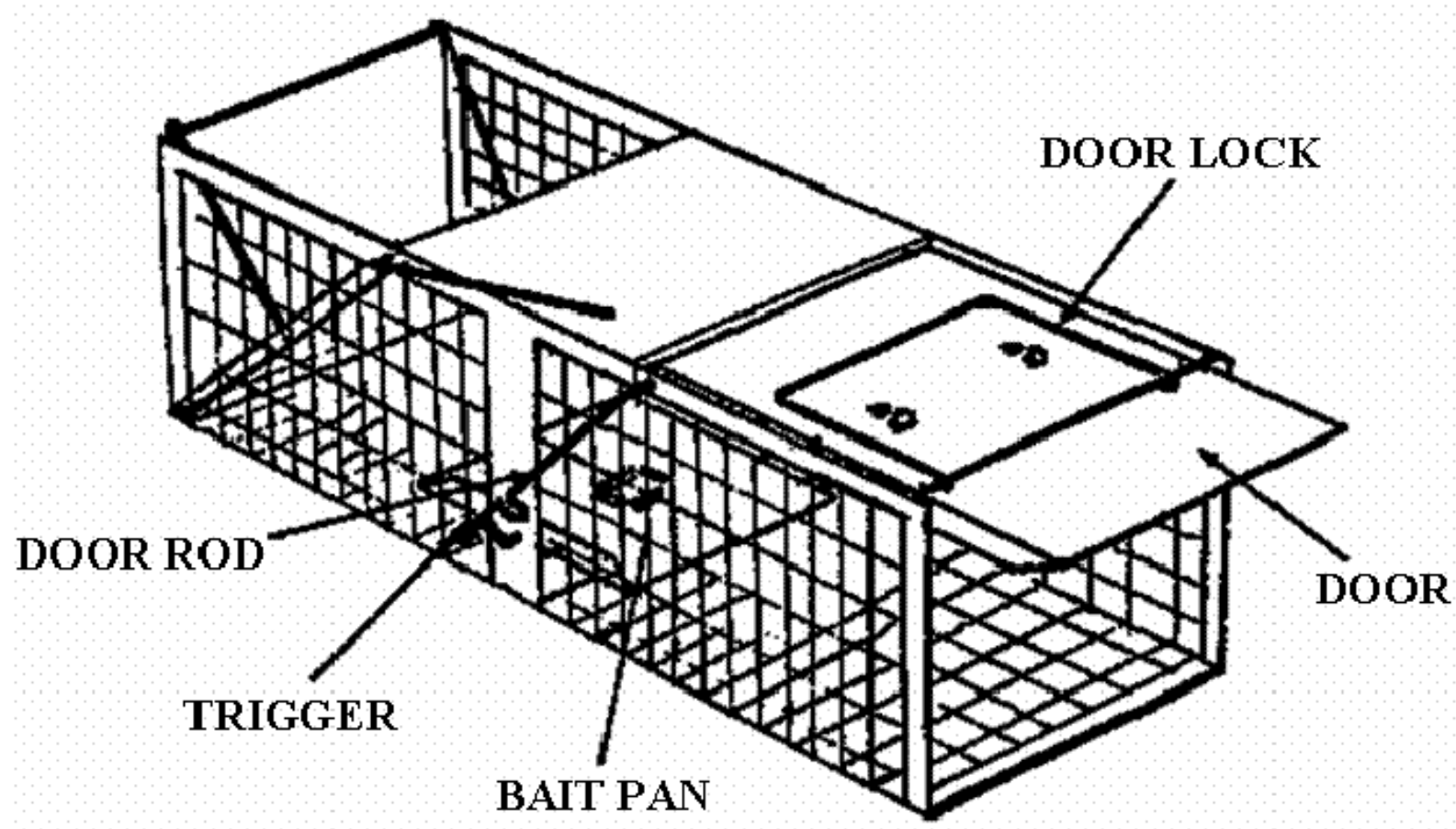

Figure 7.3.1. Rabbit Trap 


\subsection{GAME BIRDS}

\begin{tabular}{|c|c|}
\hline INTRODUCTION & $\begin{array}{l}\text { This procedure covers the collection of pheasant, quail, and chukar. } \\
\text { These game birds are collected onsite to monitor contaminant movement } \\
\text { and radionuclide uptake by birds living in and around operational areas, } \\
\text { former waste disposal sites, and waste storage areas. Game birds are also } \\
\text { obtained at offsite distant locations to obtain background measurements. }\end{array}$ \\
\hline $\begin{array}{l}\text { EQUIPMENT AND } \\
\text { SUPPLIES }\end{array}$ & $\begin{array}{l}\text { The following equipment and supplies may be needed when collecting } \\
\text { game bird samples: } \\
\text { - } \quad \text { Firearms and ammunition. } \\
\text { - Hunter's orange clothing. } \\
\text { - Safety glasses. } \\
\text { - Appropriate hearing protection. } \\
\text { - An icellular telephone. } \\
\text { - A sharp knife or scalpel. } \\
\text { - Disposable rubber or plastic gloves. } \\
\text { - Plastic bags. } \\
\text { - Tape. }\end{array}$ \\
\hline
\end{tabular}

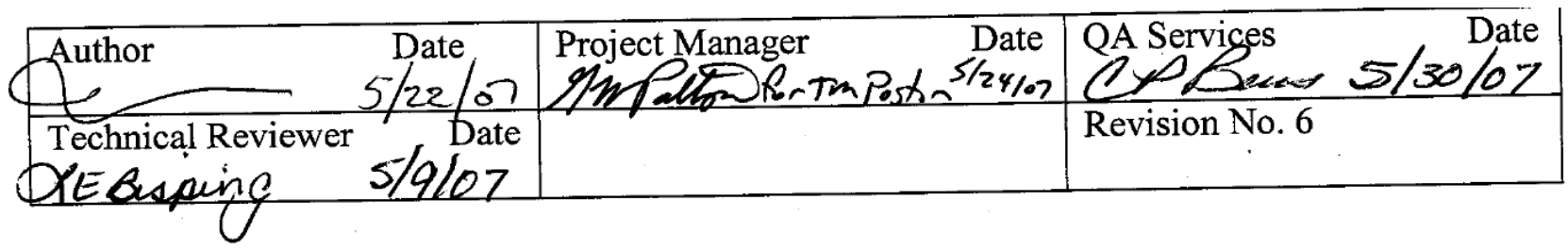




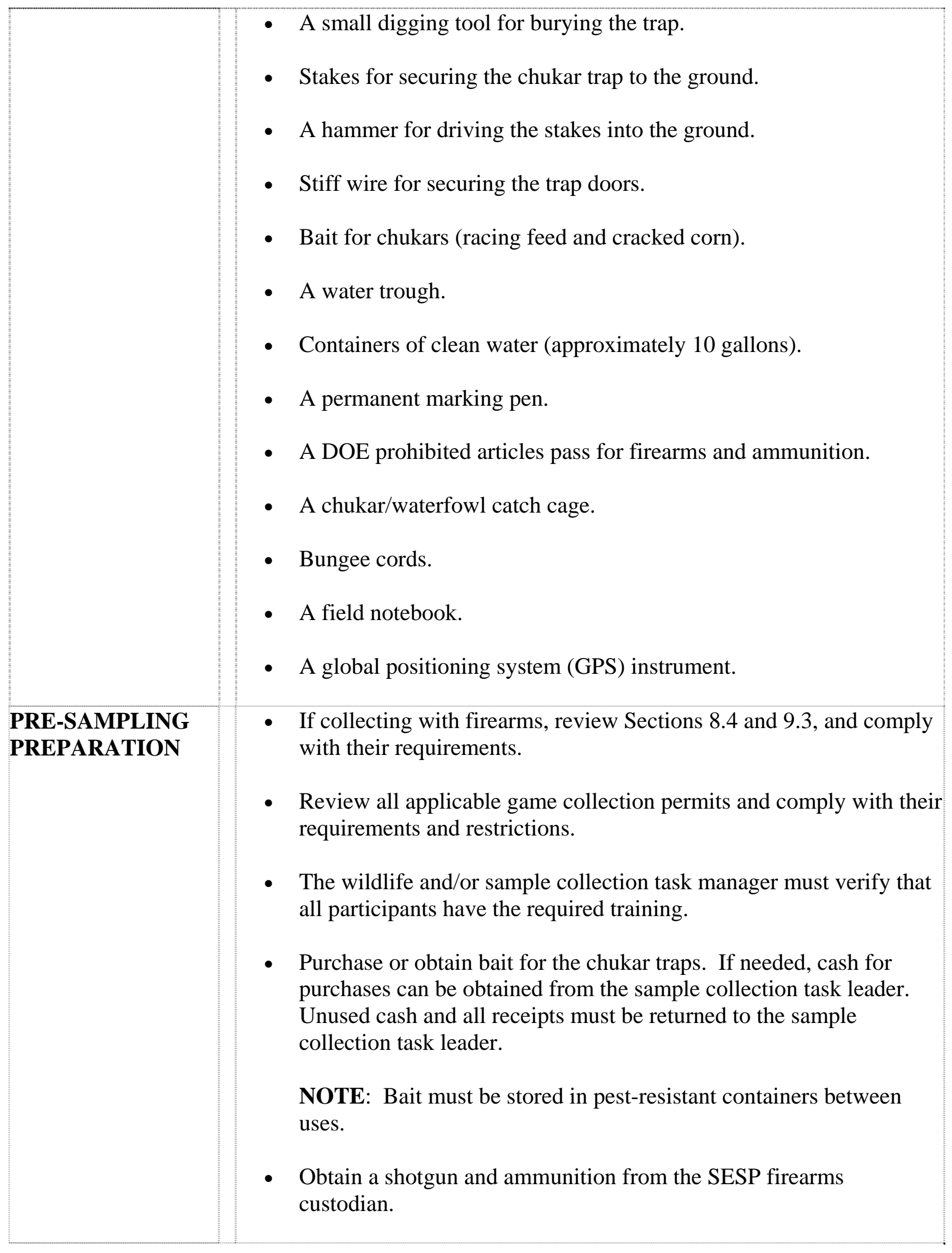




\begin{tabular}{|c|c|}
\hline & $\begin{array}{l}\text { - Notify the PNNL Operations Center and tell them where and when } \\
\text { the samples will be collected and how many people will be using } \\
\text { firearms. } \\
\text { - If collecting on the site, contact the Hanford Patrol Operations } \\
\text { Center and tell them where and when the samples will be collected } \\
\text { and how many people will be using firearms. Let the patrol know if } \\
\text { a privately owned hunting dog will be used on the site. } \\
\text { - The sample collection task leader must notify any site contractors } \\
\text { who might have personnel working in or near the collection area. }\end{array}$ \\
\hline $\begin{array}{l}\text { PHEASANT AND } \\
\text { QUAIL SAMPLE } \\
\text { COLLECTIONS }\end{array}$ & $\begin{array}{l}\text { Pheasant and quail are typically collected using a shotgun. } \\
\text { - Birds on the ground can be collected. Birds do not have to be flying. } \\
\text { NOTE: Collections near radiologically contaminated areas should } \\
\text { be avoided. If a bird enters a contaminated area, it cannot be } \\
\text { collected. If there is an accidental entry into a contaminated area, } \\
\text { collection activities must cease, the applicable RWP must be } \\
\text { followed, and the appropriate contractor personnel must be notified. } \\
\text { A radiological survey or decontamination may be necessary } \\
\text { following an accidental incursion into a contaminated area. } \\
\text { - If a bird is wounded but, for one reason or another, can't be } \\
\text { collected, record the location and species of the wounded bird in a } \\
\text { field notebook. } \\
\text { - If the bird is wounded and collected, euthanize the animal by } \\
\text { cervical dislocation. Slide the bird's neck into the slot of the } \\
\text { protection plate, and pinch its neck with the instrument. } \\
\text { - Put each collected bird into its own plastic bag. } \\
\text { - Close and tape the mouth of the bag. } \\
\text { Use the marking pen to label each bag with the species name, } \\
\text { sampling date, sampling location, and TAG ID. } \\
\text { NOTE: The TAG ID can be found in the comment column on the } \\
\text { chain-of-custody form. } \\
\text { Put bird in an ice chest with ice for transport to PNNL. }\end{array}$ \\
\hline
\end{tabular}




\begin{tabular}{|c|c|}
\hline & $\begin{array}{l}\text { - Use the GPS instrument to obtain the coordinates of the collection } \\
\text { site and record the GPS coordinates on the chain-of-custody form. } \\
\text { - Enter all other pertinent sampling information on the chain-of- } \\
\text { custody form. } \\
\text { - Notify the PNNL Operations Center when the day's sampling } \\
\text { activities are terminated. } \\
\text { - At PNNL, refrigerate the bird until it is processed. }\end{array}$ \\
\hline $\begin{array}{l}\text { IDENTIFYING A } \\
\text { CHUKAR } \\
\text { TRAPPING } \\
\text { LOCATION }\end{array}$ & $\begin{array}{l}\text { - Chukar trapping locations will be identified by a trained biologist. } \\
\text { They will look for an area that shows evidence of chukar use. } \\
\text { NOTE: Chukars usually inhabit areas near rockslides or cliffs but } \\
\text { are often found in gullies with sagebrush. Usually a source of water } \\
\text { will be nearby (within } 1 \text { mile). Look for droppings, feathers, or } \\
\text { tracks going to or from the water source. A direct sighting of } \\
\text { chukars is best. } \\
\text { - Set the traps between the chukar's daily use area and their water } \\
\text { source. An artificial water source can be set up near the trap to make } \\
\text { water access more convenient for the bird. }\end{array}$ \\
\hline $\begin{array}{l}\text { BAITING THE } \\
\text { TRAPS }\end{array}$ & $\begin{array}{l}\text { Once the collection site has been identified: } \\
\text { - Dig a hole and bury the water trough so approximately } 1 \text { in. of the } \\
\text { trough is above ground. } \\
\text { - Place a branch or stick into the trough to facilitate the escape of any } \\
\text { small mammals or rodents that fall in. } \\
\text { NOTE: Try to place the trough in the middle of a level area with a } \\
\text { radius of at least } 3 \text { feet. } \\
\text { - Fill the trough with water and sprinkle some "racing feed" on the } \\
\text { ground near the trough. } \\
\text { Check every other day for signs of chukar activity. Keep the trough } \\
\text { filled with fresh water. } \\
\text { Once it is evident that chukars are using the site: } \\
\text { - Move the trap to the sampling location. Place the trap over the } \\
\text { trough, and stake it to the ground. }\end{array}$ \\
\hline
\end{tabular}




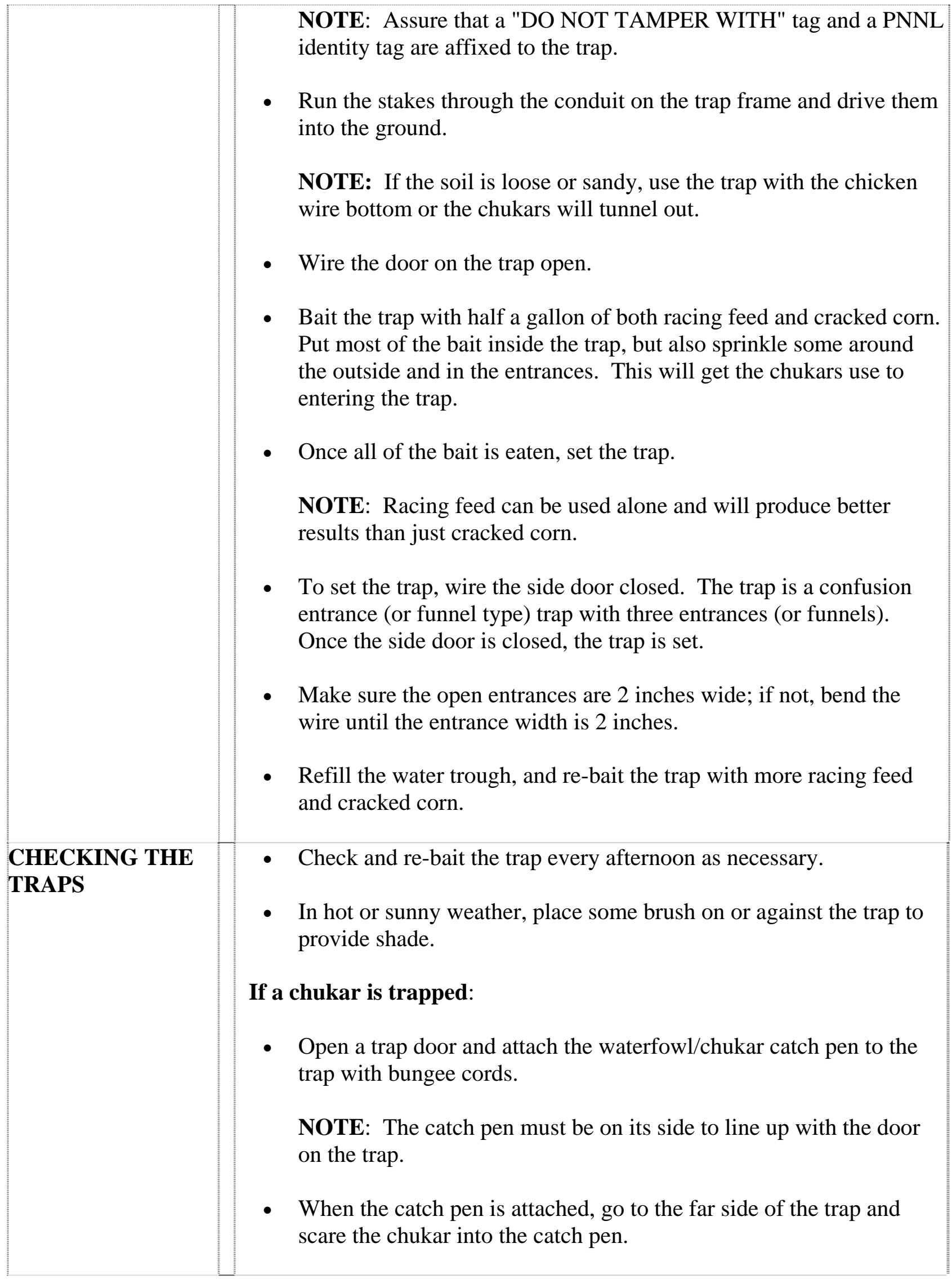




\begin{tabular}{|c|c|}
\hline & $\begin{array}{l}\text { - Slide the catch pen door closed. } \\
\text { NOTE: A trained biologist may be needed to assist with the } \\
\text { collection of caged chukars. }\end{array}$ \\
\hline $\begin{array}{l}\text { EUTHANIZING } \\
\text { AND } \\
\text { COLLECTING A } \\
\text { BIRD }\end{array}$ & $\begin{array}{l}\text { To euthanize a chukar: } \\
\text { - } \quad \text { Slide the chukar's neck into the slot of the protection plate of the } \\
\text { cervical dislocation instrument, and pinch its neck. } \\
\text { - } \quad \text { Put each collected chukar into its own plastic bag. } \\
\text { - Use the marking pen to label each bag with sampling date, sampling } \\
\text { location, and TAG ID. } \\
\text { NOTE: The TAG ID can be found in the comment column on the } \\
\text { chain-of-custody form. } \\
\text { - Put the chukar in an ice chest with ice for transport to PNNL. } \\
\text { Use the GPS instrument to obtain the coordinates of the collection } \\
\text { site and record the GPS coordinates on the chain-of-custody form. } \\
\text { - } \quad \text { Enter all other pertinent sampling information on the chain-of- } \\
\text { custody form. } \\
\text { At PNNL, refrigerate the chukar until it is processed. }\end{array}$ \\
\hline $\begin{array}{l}\text { HARVESTING } \\
\text { MUSCLE } \\
\text { SAMPLES }\end{array}$ & $\begin{array}{l}\text { NOTE: Do not harvest muscle tissues for radiological analyses until } \\
\text { the biological specialist has completed the collection of the liver } \\
\text { and/or other tissue for metals analyses. } \\
\text { - Put on disposable gloves. } \\
\text { - Remove the bird from the refrigerator and make sure that the TAG } \\
\text { ID on the bag matches the TAG ID on the chain-of-custody form. } \\
\text { - } \text { Place the bird on a clean surface. } \\
\text { - Remove the breast muscle and thighs (with bone). } \\
\text { NOTE: Do not contaminate the samples with dirt, feathers, } \\
\text { gastrointestinal (GI) tract contents, or any other foreign material. }\end{array}$ \\
\hline
\end{tabular}




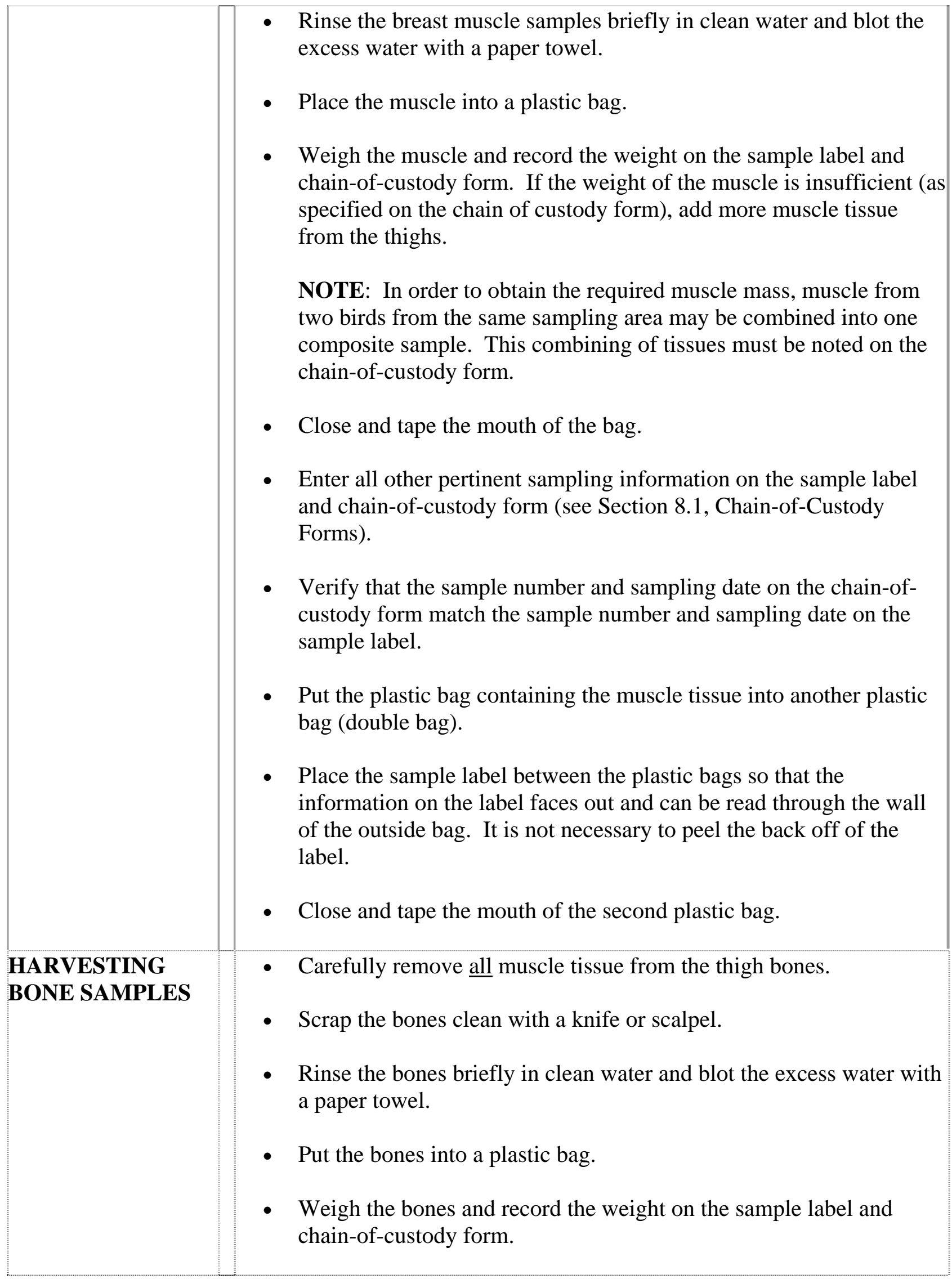


- $\quad$ Close and tape the mouth of the bag.

- Enter all other pertinent sampling information on the sample label and chain-of-custody form (see Section 8.1, Chain-of-Custody Forms).

- Verify that the sample number and sampling date on the chain-ofcustody form match the sample number and sampling date on the sample label.

- Put the plastic bag containing the bone sample into another plastic bag (double bag).

- $\quad$ Place the sample label between the plastic bags so that the information on the label faces out and can be read through the wall of the outside bag. It is not necessary to peel the back off of the label.

- $\quad$ Close and tape the mouth of the second plastic bag.

- $\quad$ Put all excess bird tissues from all birds into plastic bags. One bag may be sufficient for all tissues.

- Write "Excess bird parts" and the current date on the bags.

- $\quad$ Store the bags in a freezer until the sample collection task leader issues instructions for disposal.

GAME BIRDS COLLECTED FOR THE WASHINGTON STATE DEPARTMENT OF HEALTH

COMPLETING CHAIN OF CUSTODY FORMS AND SUBMITTING SAMPLES FOR ANALYSES
Game birds may be collected and provided to the Washington State Department of Health. These birds should be bagged (whole), labeled as described in PHEASANT AND QUAIL SAMPLE COLLECTIONS, and stored in a freezer at PNNL until they are relinquished to the Department of Health (see Section 8.1 for relinquishing instructions).

If samples cannot be submitted to an analytical laboratory on the day they are collected or processed, store the samples in a freezer or refrigerator.

See Section 8.1, Chain-of-Custody Forms, for further requirements for completing chain-of-custody forms and submitting samples to an analytical laboratory. 


\subsection{DEER AND ELK}

\begin{tabular}{|c|c|}
\hline INTRODUCTION & $\begin{array}{l}\text { This section includes procedures for collecting muscle, bone, and liver } \\
\text { samples from deer and elk on the Hanford Site. }\end{array}$ \\
\hline $\begin{array}{l}\text { EQUIPMENT AND } \\
\text { SUPPLIES }\end{array}$ & 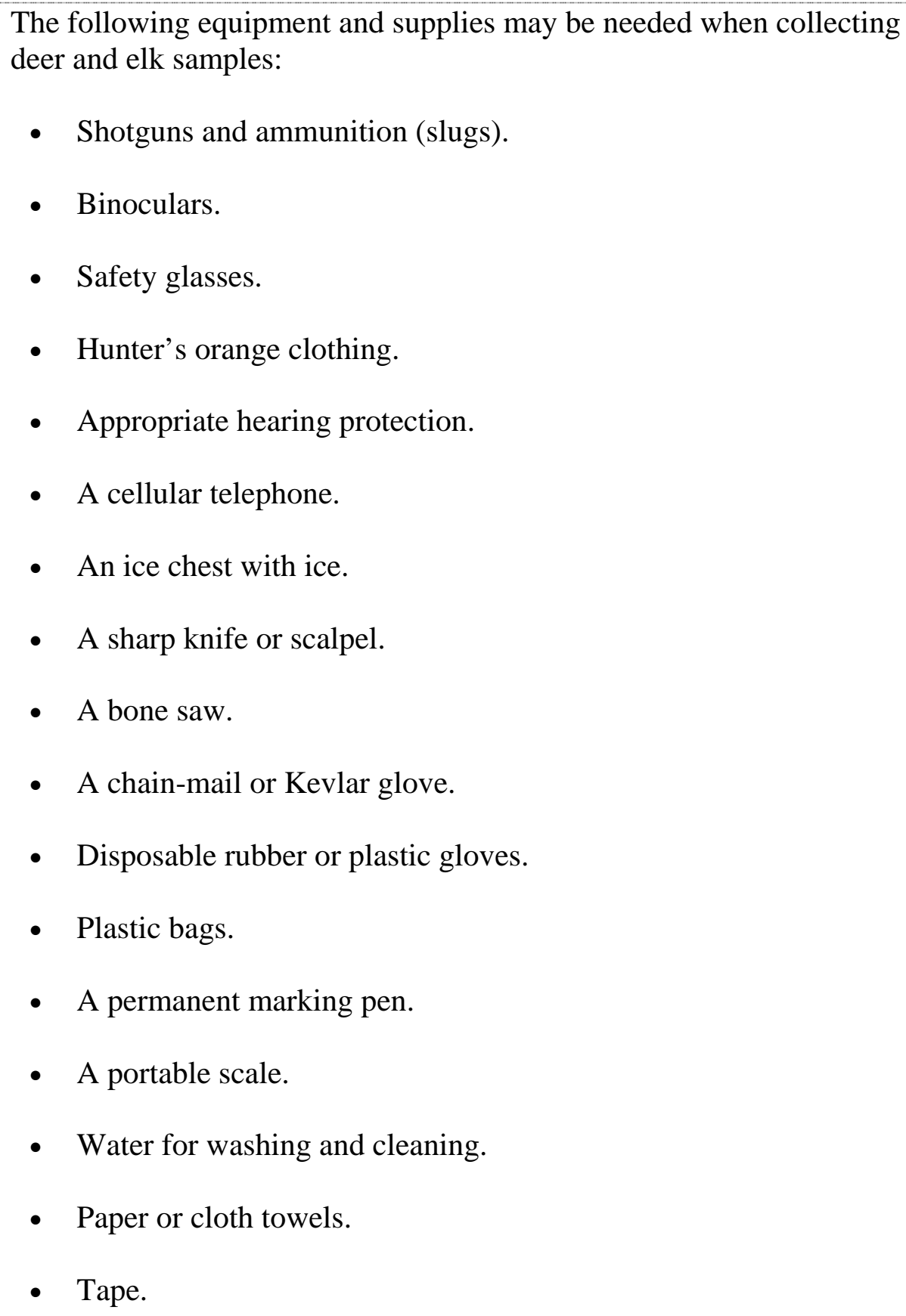 \\
\hline
\end{tabular}

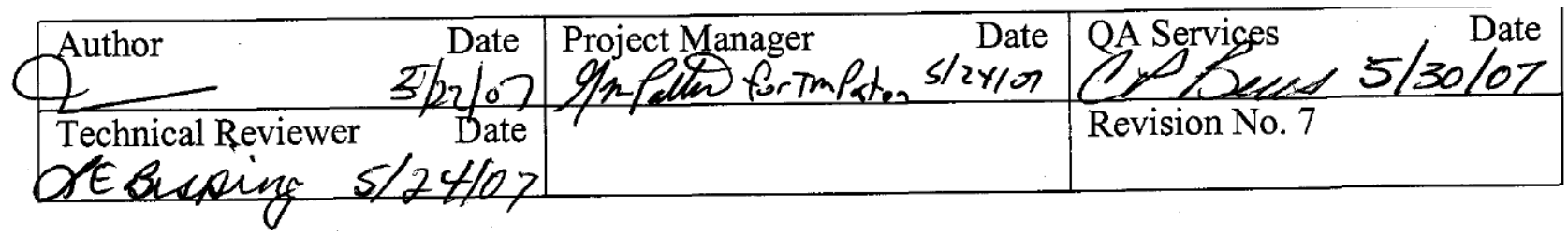




\begin{tabular}{|c|c|}
\hline & $\begin{array}{l}\text { - A headlamp or flashlight for night work. } \\
\text { - } \text { Valid game collection permits. } \\
\text { - } \text { Sample labels and chain-of-custody form. } \\
\text { - A DOE prohibited articles pass for firearms and ammunition. } \\
\text { - A global positioning system (GPS) instrument. }\end{array}$ \\
\hline $\begin{array}{l}\text { PRE-SAMPLING } \\
\text { PREPARATION }\end{array}$ & $\begin{array}{l}\text { - If collecting with firearms, review Sections } 8.4 \text { and 9.3, and comply } \\
\text { with their requirements. } \\
\text { - } \quad \text { Review all applicable game collection permits and comply with their } \\
\text { requirements and restrictions. } \\
\text { - The wildlife or sample collection task manager must verify that all } \\
\text { participants have the required training. } \\
\text { - If appropriate, obtain a shotgun and ammunition from the SESP } \\
\text { firearms custodian. } \\
\text { If firearms will be used, notify the PNNL Operations Center and tell } \\
\text { them where and when the samples will be collected and how many } \\
\text { people will be using firearms. } \\
\text { If using firearms on the site, contact the Hanford Patrol Operations } \\
\text { Center and tell them where and when the samples will be collected } \\
\text { and how many people will be using firearms. } \\
\text { If using firearms on the site, the sample collection task leader must } \\
\text { notify any site contractors who might have personnel working in or } \\
\text { near the collection area. }\end{array}$ \\
\hline $\begin{array}{l}\text { TISSUE/ORGAN } \\
\text { COLLECTIONS IN } \\
\text { THE FIELD }\end{array}$ & $\begin{array}{l}\text { Deer and elk tissue and organ samples may be obtained from animals } \\
\text { killed by traffic or by sample collection personnel using firearms. Tissues } \\
\text { are collected in the field and may be transported to PNNL for final } \\
\text { preparation for submission to the analytical laboratory. If tissues can be } \\
\text { appropriately prepared in the field, it is acceptable to do so. The animal } \\
\text { carcass is left at the collection site. } \\
\text { - Wear disposable gloves when removing tissue and bone samples. } \\
\text { - Wear the cut-proof chain mail or Kevlar glove when using the knife } \\
\text { to remove tissues. }\end{array}$ \\
\hline
\end{tabular}


NOTE: Do not collect tissues that have been contaminated with dirt, hair, gastrointestinal (GI) tract contents, or any other foreign material. Tissues should also be free of shotgun slugs.

\section{When collecting muscle tissue from the deer/elk:}

- Remove muscle tissue from the hind legs, if possible.

NOTE: It may be necessary to obtain muscle elsewhere on the body if the legs are in poor condition or missing.

- If appropriate, proceed to the PREPARING MUSCLE SAMPLES section, otherwise continue as follows.

- Put the muscle into a clean plastic bag.

- Weigh the muscle. If the weight of the muscle is insufficient (as specified on the chain of custody form), add more muscle tissue.

- $\quad$ Close and tape the mouth of the plastic bag.

- $\quad$ Use the marking pen to label the bag with sampling date, species name, sampling location, and TAG ID.

NOTE: The TAG ID can be found in the comment column on the chain-of-custody form.

- $\quad$ Put the bag into the ice chest with ice for transport to PNNL.

- $\quad$ Refrigerate the sample at PNNL until it is processed.

\section{When collecting bone samples from deer/elk:}

- Use the bone saw to remove a large portion of the thigh for a bone sample.

NOTE: It may be necessary to obtain bone elsewhere on the body if the legs are in poor condition or are gone.

- Remove as much muscle from the bone as possible.

- If appropriate, proceed to the PREPARING BONE SAMPLES section, otherwise continue as follows.

- $\quad$ Put the bone in a plastic bag. 


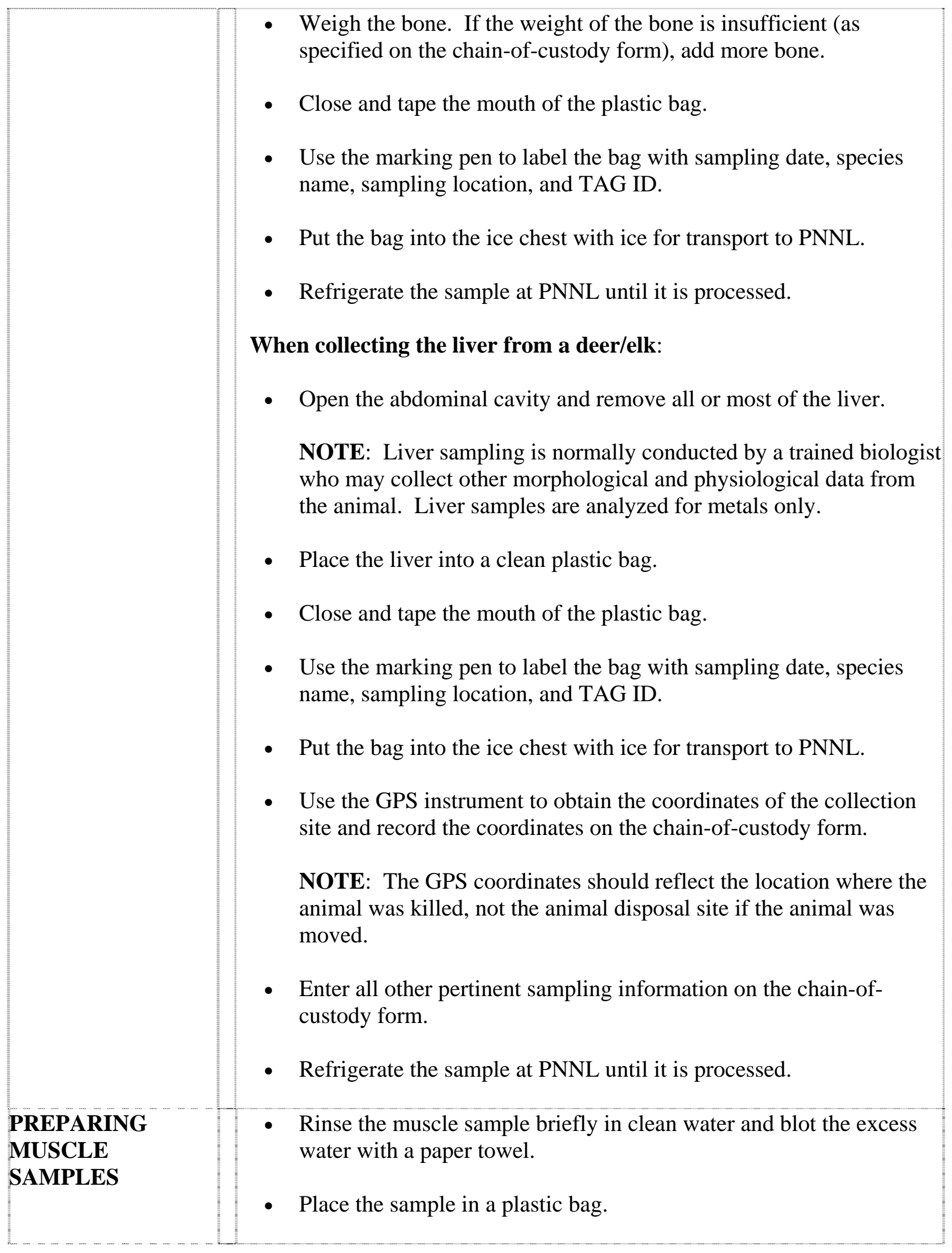




\begin{tabular}{|c|c|}
\hline & $\begin{array}{l}\text { - Weigh the sample and record the weight on the sample label and } \\
\text { chain-of-custody form. } \\
\text { - } \quad \text { Close and tape the mouth of the plastic bag. } \\
\text { - } \quad \text { Enter all pertinent sampling information on the sample label and } \\
\text { chain-of-custody form (see Section 8.1, Chain-of-Custody Forms). } \\
\text { - Verify that the sample number and sampling date on the chain-of- } \\
\text { custody form match the sample number and sampling date on the } \\
\text { sample label. } \\
\text { - Place the sample label between the plastic bags so that the } \\
\text { information on the label faces out and can be read through the wall } \\
\text { of the second bag. It is not necessary to peel the back off the label. } \\
\text { - Close and tape the mouth of the second plastic bag. }\end{array}$ \\
\hline $\begin{array}{l}\text { PREPARING } \\
\text { BONE SAMPLES }\end{array}$ & 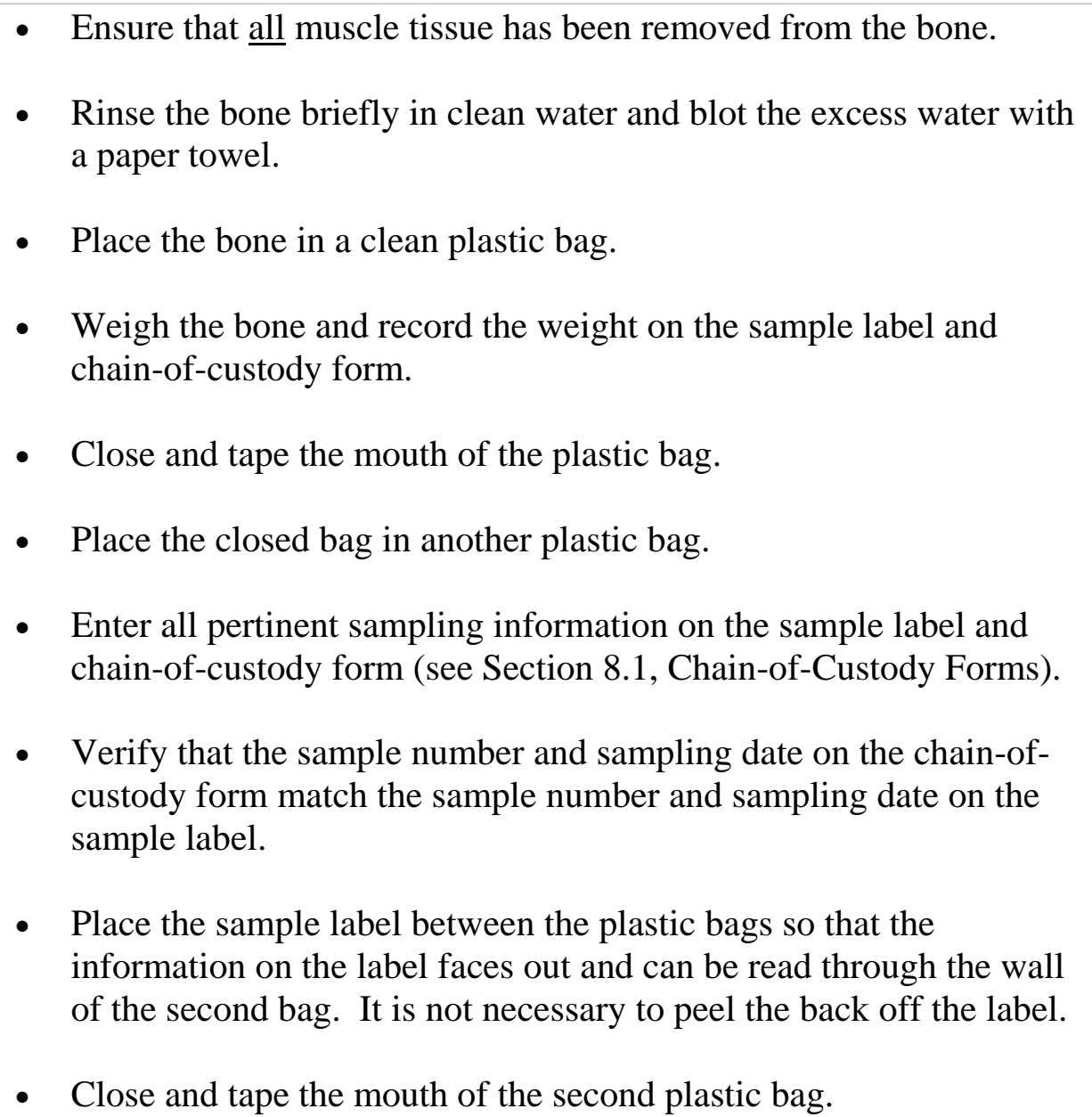 \\
\hline
\end{tabular}




\begin{tabular}{|c|c|}
\hline & $\begin{array}{l}\text { - Put all excess tissues in a plastic bag. } \\
\text { - Use the marking pen to write "Excess deer or elk parts" and the date } \\
\text { on the bag. } \\
\text { - Store the bag in a freezer until the sample collection task leader } \\
\text { issues instructions for disposal. }\end{array}$ \\
\hline \begin{tabular}{l|} 
DEER AND ELK \\
SAMPLES \\
COLLECTED FOR \\
THE \\
WASHINGTON \\
STATE \\
DEPARTMENT OF \\
HEALTH
\end{tabular} & $\begin{array}{l}\text { Deer and elk samples may be collected and provided to the Washington } \\
\text { State Department of Health. These samples should be bagged, labeled as } \\
\text { described in TISSUE COLLECTIONS IN THE FIELD, and stored in a } \\
\text { freezer at PNNL until they are relinquished to the Department of Health } \\
\text { (see Section } 8.1 \text { for relinquishing instructions). } \\
\text { NOTE: These samples will probably be collected from the same animal } \\
\text { sampled by PNNL and the TAG ID should reflect this. }\end{array}$ \\
\hline \begin{tabular}{l|} 
COMPLETING \\
CHAIN OF \\
CUSTODY FORMS \\
AND SUBMITTING \\
SAMPLES FOR \\
ANALYSES
\end{tabular} & $\begin{array}{l}\text { If samples cannot be submitted to an analytical laboratory on the day they } \\
\text { are collected or processed, store the samples in a freezer or refrigerator. } \\
\text { See Section 8.1, Chain-of-Custody Forms, for further requirements for } \\
\text { completing chain-of-custody forms and submitting samples to an } \\
\text { analytical laboratory. }\end{array}$ \\
\hline
\end{tabular}




\subsection{MISCELLANEOUS PROCEDURES}

\begin{tabular}{|l||l|}
\hline INTRODUCTION & $\begin{array}{l}\text { The procedures discussed here are either not routinely used for sample } \\
\text { collections or they broadly supplement other sample collection procedures } \\
\text { described in this manual. Included in this section are procedures for the } \\
\text { following: }\end{array}$ \\
$\begin{array}{l}\text { - } \\
\text { Chain-of-custody forms (Section 8.1). }\end{array}$ & $\begin{array}{l}\text { Radiation work permits (Section 8.2). } \\
\text { - }\end{array}$ \\
$\begin{array}{l}\text { Radiological surveys of samples (Section 8.3). } \\
\text { (GPS) instrument (Section 8.5). }\end{array}$ \\
\hline
\end{tabular}

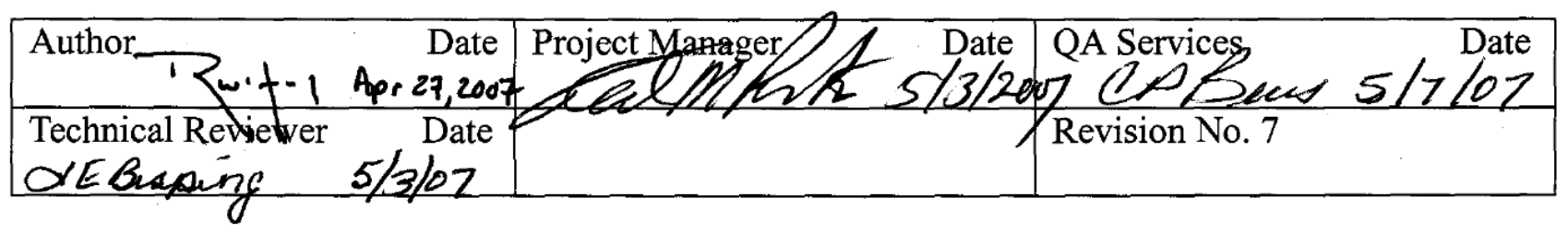




\subsection{CHAIN-OF-CUSTODY FORMS}

\begin{tabular}{|c|c|}
\hline INTRODUCTION & $\begin{array}{l}\text { The following procedures are applicable to all chain-of-custody (COC) forms } \\
\text { used for Surface Environmental Surveillance Project (SESP) work. } \\
\text { The collection of samples or measurements by sample collection personnel is } \\
\text { documented on COC forms. Project specific COC forms (i.e., trip sheets) } \\
\text { also serve as field-sampling record forms. } \\
\text { Several types of media-specific COC forms are used when collecting routine } \\
\text { project samples or measurements (Figures 8.1.1 - 8.1.6). } \\
\text { The importance of providing complete and accurate information on COC } \\
\text { forms cannot be overemphasized. The information may be important when } \\
\text { interpreting or accounting for anomalies in the analytical data. }\end{array}$ \\
\hline $\begin{array}{l}\text { CHAIN-OF- } \\
\text { CUSTODY FORM } \\
\text { ENTRIES }\end{array}$ & $\begin{array}{l}\text { Data must be entered in ink. Errors or changes must be marked out with a } \\
\text { single line, initialed, and dated. All entries must be legible and clearly } \\
\text { written so that they will be understandable to future readers. } \\
\text { As much as possible, the form must be filled out as the samples or } \\
\text { measurements are collected. } \\
\text { All recorded times must be in military format (i.e., 24-hour clock). } \\
\text { Any observations about conditions near the sampling site that might } \\
\text { influence analytical results (e.g., ground disturbances, nearby brush fires) } \\
\text { should be noted in the comment section or on the lower half of the COC form } \\
\text { if there is not enough room in the comment section. The comment, and the } \\
\text { sampling location it applies to, must be tied together by placing an asterisk at } \\
\text { both locations on the form. } \\
\text { All problems with sampling systems or samples must be recorded in the COC } \\
\text { comment section or on the lower half of the COC form if there is not enough } \\
\text { room in the comment section. The comment at the bottom of the page, and } \\
\text { the sample or sampling location it applies to, must be tied together with a } \\
\text { footnote indicator. }\end{array}$ \\
\hline
\end{tabular}

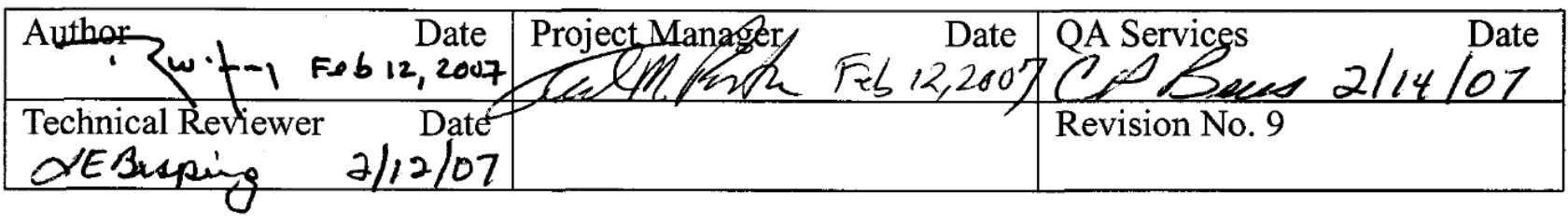


The name of the sample collector (more than one collector can be listed) and the collection date must be printed in the appropriate spaces on each COC form.

Some biota samples consist of animal tissues. Generally, there is no COC form for the entire animal (e.g., deer, rabbit). COC forms are only generated for individual tissue samples (e.g., muscle, bone). When animals are obtained using firearms, traps, nets, fishing gear, etc., the person who obtains the sample (i.e., whole organism) is the "collector." The person who removes the tissue samples from the organism following the initial collection is the "harvester." The "collector" and the "harvester" can be the same individual. Tissues removed from animals killed by traffic, or shot and left in the field, are "collected," not "harvested."

The collector's name and the collection date should be printed at the top of the COC form. The collection date should also be written in the "Sample Date" column for each tissue sample. If one person is both the "collector" and the "harvester", then that person should print his/her name and the appropriate dates in the "Collected by/ Date" locations and in the "Harvested by/Date” locations.

Chain-of-custody form entries or changes made by anyone not listed as a collector or harvester on the form must be signed (legibly) and dated.

If the person filling out the COC form is someone other than the sample collector or sample harvester, that person must be identified as the "scribe" somewhere on the form with a printed name.

It is important to verify that the sampling dates on all sample labels and COC forms are correct. Labels and COC forms are often printed days or weeks before sampling occurs and pre-printed dates may need to be changed to reflect the correct dates.

Sample volume or sample size must be recorded on the COC form and sample labels in the appropriate locations.

If a non-routine sample is to be collected, the data management task leader should generate a COC form and label prior to sample collection activities. If this is not possible, sample collection information should be hand-recorded in the field and transferred to a COC form as soon as possible after a sample is obtained. 
Global positioning system (GPS) coordinates (lat/long in hdd.ddddd) should be recorded at all non-routine sampling locations and for all routine samples that are collected away from established collection sites (e.g., an air-sampling hutch) but within a designated sampling area (e.g., food and farm products or, biota sampling areas). Procedures for using one GPS system currently used by SESP sample-collection personnel are outlined in Section 8.6. GPS readings should be recorded in the description column to the left of the appropriate location name. When only one location is listed on a COC form, the GPS coordinates can be entered anywhere in the description column.

UNSUCCESSFUL SAMPLING ATTEMPTS
If a scheduled sampling attempt is unsuccessful, or the volume of an air sample is too small for analytical purposes (see Sections 3.1 and 3.2), the uncollected or small-volume sample is classified as a "NO SAMPLE." A reason for the unsuccessful collection or small sample must be written on the COC form.

If the unsuccessfully collected sample will be collected at a later date, but is on a COC form with samples that were successfully collected, it must be lined-out on the COC form and a comment must be written that indicates the sample will be collected at a later date. Another COC form for the uncollected sample must be requested from the data management task leader prior to its future collection.

If the unsuccessfully collected sample is normally combined with other samples to form a composite sample (the sample label will indicate whether the sample is to be saved for a composite sample), it must be labeled a "NO SAMPLE" and the requested analyses must be crossed off the sample label and, if appropriate, the Daily Trip Log report (e.g., Figure 8.1.7). The COC form and the label for this uncollected sample must be submitted to the analytical laboratory even though there is no sample being submitted for analysis.

If the unsuccessfully collected sample is not part of a composite sample, is not on a COC with other collected samples, and will be collected at a later date, the sample collector can keep the COC form until the sample is collected or until it's obvious that it will never be collected. If the sample cannot be collected at a later date, the COC form must be returned to the data management task leader with the date of the last attempted sampling (if an attempt was made) and a comment indicating that the sampling attempt was unsuccessful. The words "NO SAMPLE" must be written on the form. If there was no attempt to collect the sample, a note stating this should be written on the COC form. All such COC notations must be initialed and dated. 
COMBINING BIOTA SAMPLES

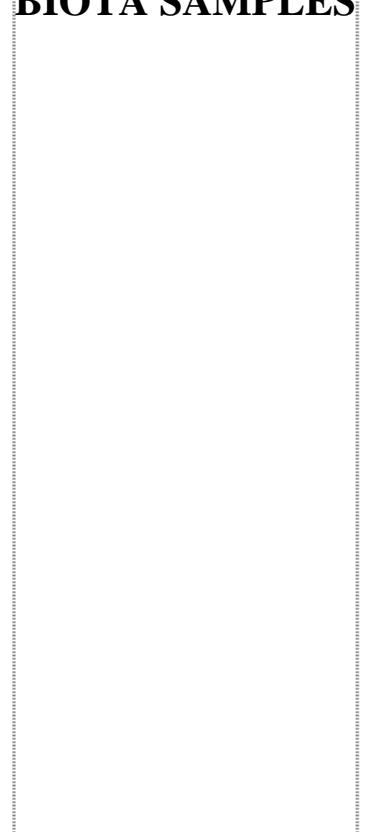

STORING SAMPLES
In order to obtain the tissue mass necessary for some analyses, small organisms, or parts of organisms may be combined (composited) to form a single large sample.

It may take several sampling attempts at fixed locations (e.g., trap lines) or opportunistic locations (e.g., birds, fish) over a period of days to collect enough organisms for a sample, and the last day of sampling will be considered the official sampling date. This date must be entered on the COC form as the sampling date.

The official sampling location (GPS coordinates) for a combined sample will be the location where the largest portion (mass) of the sample was collected.

The collection dates, sample weights, and sampling location coordinates of the other portions of the sample must also be recorded in the comment area on the SESP COC form or in a laboratory record book (LRB), depending on the biota task leader's preference. If the data are recorded in a LRB, the number of the LRB must be written on the COC form.

If a collected sample is stored at PNNL prior to analysis, the sample must be labeled so that it can be identified (attach the sample label if appropriate) and the sample collector must sign and date the COC form (in the "Relinq. By:" space) and note (in the "Relinq. To:" space) that the sample was placed into locked storage at a specific location (e.g., Sigma 5 locked storage) on a specific date. Unless the collector relinquishes the sample to another person, the person relinquishing the sample to locked storage must be one of the collectors identified on the COC form.

When the samples are removed from locked storage for tissue harvesting, or delivery to an analytical laboratory, it must be recorded on the COC form that the samples were removed from locked storage on a specific date (use the "Relinq. By:" space) and relinquished to the person taking the samples from locked storage (use the "Relinq. To:" space).

If all of the pre-printed relinquishing spaces at the bottom of the COC form are used, and additional spaces are needed, the "Relinq. By:" and "Relinq. To:" information can be hand written elsewhere on the front of the form in a similar format.

If a sample will be stored for an extended period of time (i.e., archived), such as a farm product sample collected and retained for possible follow-up analyses, the original COC form must be provided to the data management task leader when the sample is placed into storage, and a copy of the form must be filed as directed by the sample collection task leader. 


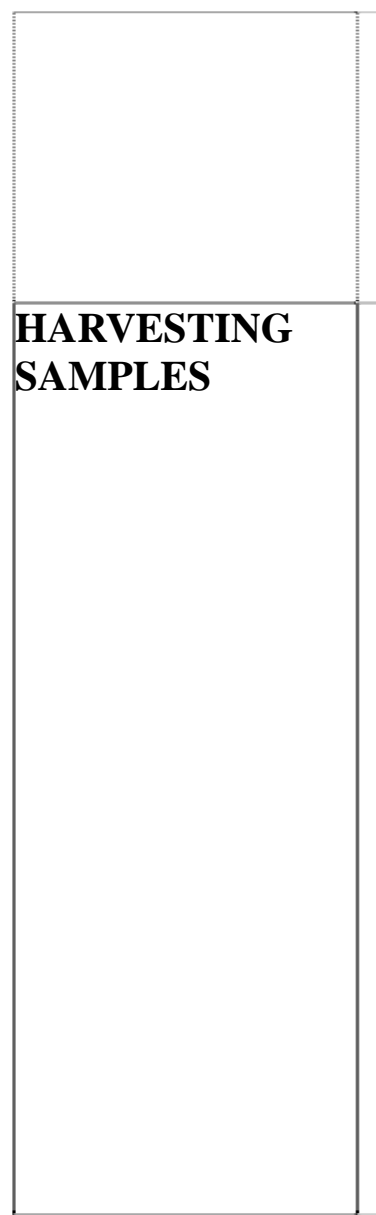

TAG I.D.

The COC form for a sample collected and stored for later delivery to an offsite agency or analytical laboratory (e.g., the Washington State Department of Health, the Food and Drug Administration, the 320 Building) must be photocopied prior to being filed. The photocopy is provided to the data management task leader.

Sometimes whole organisms (e.g., rabbit, bird, clam) are collected and then separated into tissue samples (e.g., organ, muscle, bone) for analysis. The "harvest" of tissues can be done in the laboratory or in the field, depending on circumstances or collection requirements

The harvesting of tissue samples should be documented on the COC forms as described below.

The transfer of the organism from the collector, or locked storage, to the harvester must be documented on the COC form. If the transfer is from the collector to the harvester, both need to sign as either relinquishing or receiving the sample. If the transfer is from storage to the harvester, see the procedures discussed in STORING SAMPLES, above. Once the harvest has taken place, the sample must be relinquished back to the collector or to locked storage unless the harvester immediately ships or delivers the sample to an analytical laboratory or an offsite agency. NOTE: the sampling date on the COC form will always be the date that the entire organism was collected, not the date that the tissues were harvested.

Each wildlife sample (whole organism) is assigned a Tag Identification (I.D.) number by the data management task leader. Each sample harvested from a single organism (e.g., bone, muscle, liver) will have the same Tag I.D. number and this number will be on the COC form (in the comment column) for each harvested tissue. This must be verified prior to submitting the harvested samples for analysis. If the Tag I.D. numbers for tissues of a single organism differ, contact the data management task leader for instructions.

CHAIN-OFCUSTODY FORM REVIEWS
Before submitting samples to an analytical laboratory or storing samples that will be shipped or delivered to an offsite agency representative (e.g., Washington State Department of Health) or analytical laboratory (e.g., FDA), the SESP COC forms must be reviewed for accuracy and completeness by the sample collection task leader, the data management task leader, or another SESP task leader who is familiar with these COC form procedures. The reviewer must sign and date each form (in the "Reviewed By:" field) to acknowledge the review. The collector/harvester and the reviewer cannot be the same person. 
DELIVERING

SAMPLES TO A

LABORATORY

OR AN OFFSITE AGENCY
If the person delivering the samples to a laboratory or offsite agency is not the collector, the samples must be relinquished from the collector, or locked storage, to the delivery person before the samples are taken to the laboratory.

At the laboratory, the delivery person and the person accepting delivery of the samples must compare the sample numbers on the sample labels with the sample numbers on the COC forms to verify that the correct samples are being submitted and that all samples are accounted for.

The delivery person must then sign and date the COC form in the appropriate "Relinq. By:" space and the person receiving the sample must sign and date the forms in the appropriate "Relinq. To:" space.

The person delivering the samples must fold back the COC form's description column (left side of form) along the double-dashed lines and photocopy the remainder of the form. The samples are supposed to go the laboratory "blind" so that the laboratory does not know where the samples were collected. (NOTE: unless otherwise instructed, folding the description column prior to photocopying the signed form is only necessary when samples are delivered to STL, Richland, or, if appropriate, its replacement).

The laboratory will keep the photocopies of the COC forms for its records along with the Daily Trip Log reports (e.g., Figure 8.1.7). The sample delivery person will return the original copies of the COC forms to the data management task leader.

When samples are delivered to a person from an offsite agency (e.g., Washington State Department of Health), the sample delivery person must obtain the relinquishing signatures and then photocopy the entire COC form. The original forms will be given to the agency representative and the photocopies must be delivered to the data management task leader.

Samples to be analyzed in the 320 Building must be delivered to a person in the 320 Building on the day of collection (following the delivery procedures outlined in the above paragraph), remain in the possession of the collector (i.e., locked in collection vehicle), or be placed into locked storage in the Sigma 5 Building until arrangements can be made for someone in the 320 Building to receive them. They can be "Relinq. To:" storage at the 320 Building after someone has acknowledged receiving them.

Samples stored in the Sigma 5 Building prior to delivery to the 320 Building must be "Relinq. To:" Sigma 5 locked storage. If the samples will be stored longer than overnight or over a weekend, the COC forms for the samples must be photocopied and the photocopies must be given to the data management task leader. The original forms must be stored in a file folder in the office of the environmental RCT. 


\begin{tabular}{|c|c|}
\hline $\begin{array}{l}\text { SHIPPING } \\
\text { SAMPLES }\end{array}$ & $\begin{array}{l}\text { If the samples will be shipped to another laboratory (e.g., Sequim) for } \\
\text { analysis, the person preparing the samples for shipping must ensure that the } \\
\text { correct samples are being shipped by comparing the sample numbers on the } \\
\text { sample labels to the sample numbers on the COC forms. The person must } \\
\text { then assure that the COC forms have been reviewed by the appropriate person } \\
\text { (see CHAIN-OF-CUSTODY FORM REVIEWS, above). The samples are } \\
\text { then relinquished from the collector to the package carrier (e.g., FedEx, UPS, } \\
\text { USPS), or from locked storage to the person shipping them, then to the } \\
\text { package carrier. The package tracking (FedEx) or shipping number must be } \\
\text { recorded on the COC forms in the "Relinq. To:” space. } \\
\text { Once the tracking number is recorded on the COC forms, photocopies of the } \\
\text { forms are given to the data management task leader and the original forms are } \\
\text { packaged with the samples and mailed to the laboratory. } \\
\text { If possible, obtain a copy of the delivery receipt so that it can be filed with the } \\
\text { COC forms, or with copies of the COC forms, for the shipped sample. FedEx } \\
\text { shipment receipts can be obtained at the FedEx web site by entering the } \\
\text { package tracking number. }\end{array}$ \\
\hline $\begin{array}{l}\text { SUBMITTING } \\
\text { ARCHIVED } \\
\text { SAMPLES TO AN } \\
\text { ANALYTICAL } \\
\text { LABORATORY }\end{array}$ & $\begin{array}{l}\text { When an archived sample is to be submitted to an analytical laboratory, the } \\
\text { original COC form, or, in some circumstances, a new COC form must be } \\
\text { obtained from the data management task leader. } \\
\text { Chain-of-custody forms for archived samples should be filled out as } \\
\text { described in the section STORING SAMPLES, above. When samples and } \\
\text { COC forms are ready for submittal, follow the procedures described under } \\
\text { DELIVERING SAMPLES TO A LABORATORY OR AN OFFSITE } \\
\text { AGENCY or SHIPPING SAMPLES, above. }\end{array}$ \\
\hline $\begin{array}{l}\text { DISPOSING OF } \\
\text { SAMPLES }\end{array}$ & $\begin{array}{l}\text { The COC forms for samples that are disposed of without being analyzed must } \\
\text { be returned to the database management task leader with the words } \\
\text { "SAMPLES THROWN AWAY AND NOT ANALYZED", the printed name } \\
\text { of the person disposing of the samples, and the disposal date, written on the } \\
\text { forms. }\end{array}$ \\
\hline
\end{tabular}


Description

Date: THURSDAY 01/18/2007 Collected By (print):

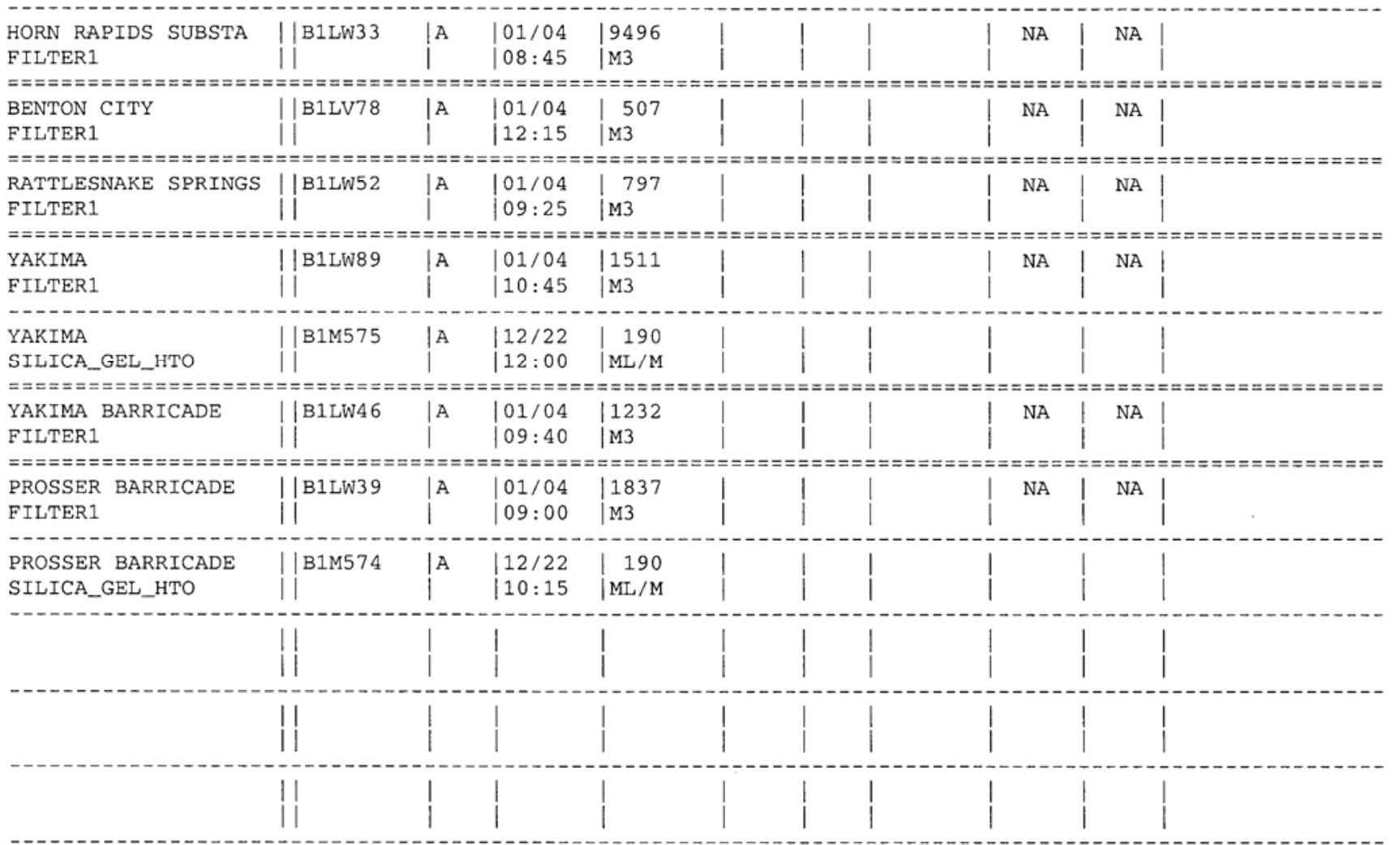

Reling. By: Relinq. By: Reling. By

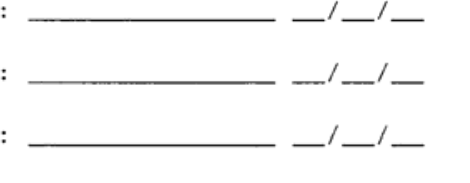

Reviewed By:
Reling. To

Reling. To

Relinq. To

(PNL)

F89144 Air Cal.

Figure 8.1.1. Chain-of-Custody Form for Air Samples 
Route: 01 Lab: STLRL Contract \#3211-A-B2 Battelle - F89148

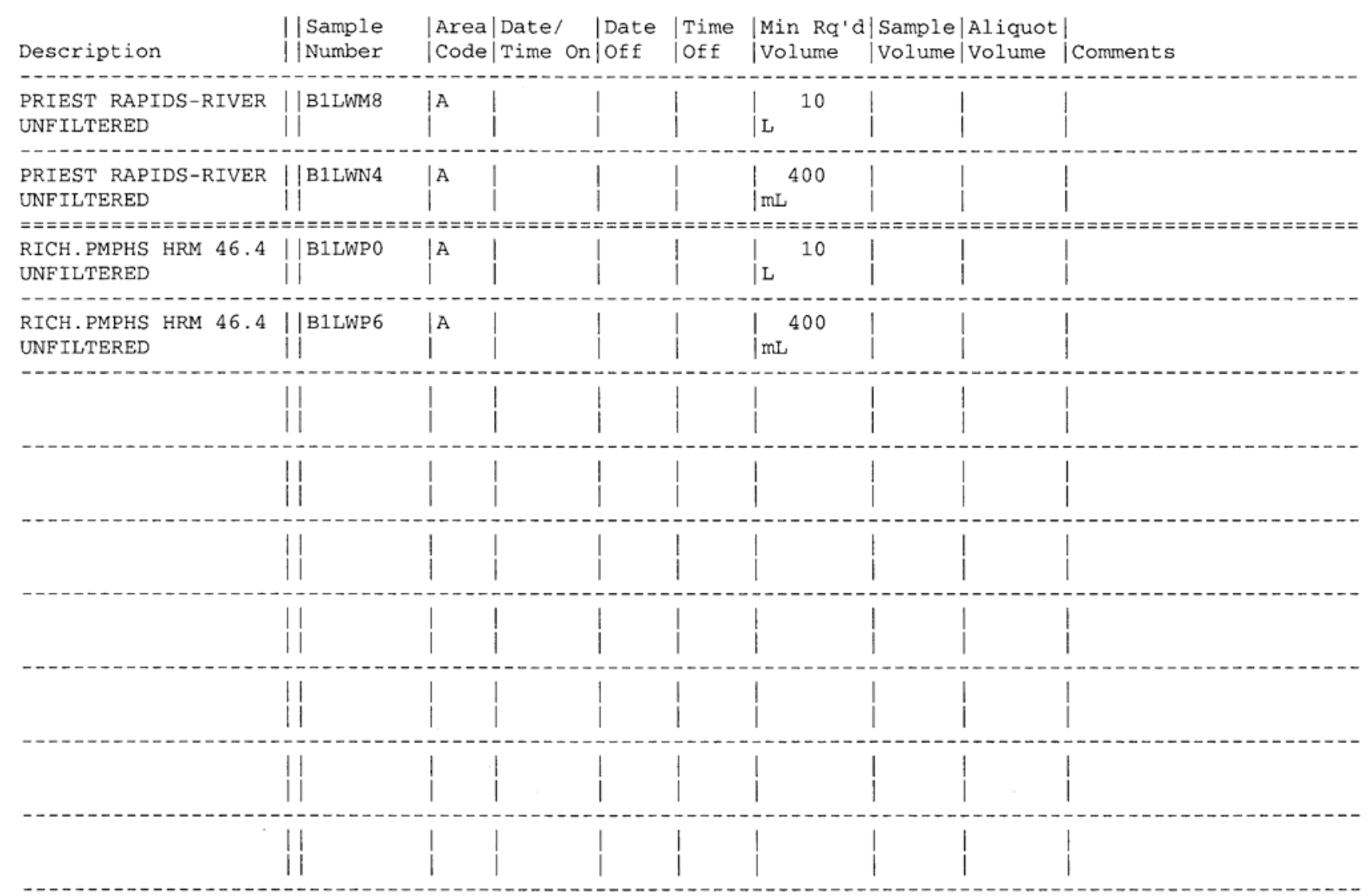

Reling. By:

Reling. By:

Reling. By

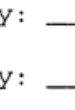

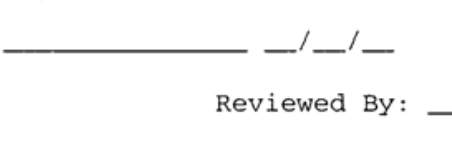

Reling. To

Reling. To

Relinq. To

$$
\text { (PNL) }
$$

Figure 8.1.2. Chain-of-Custody Form for Composited Water Samples 
Route: 02 Lab: STLRL Contract \#3211-A-B2 Battelle - F89148

Sched Date: WEDNESDAY 10/04/2006 Collected By (print): — Date:

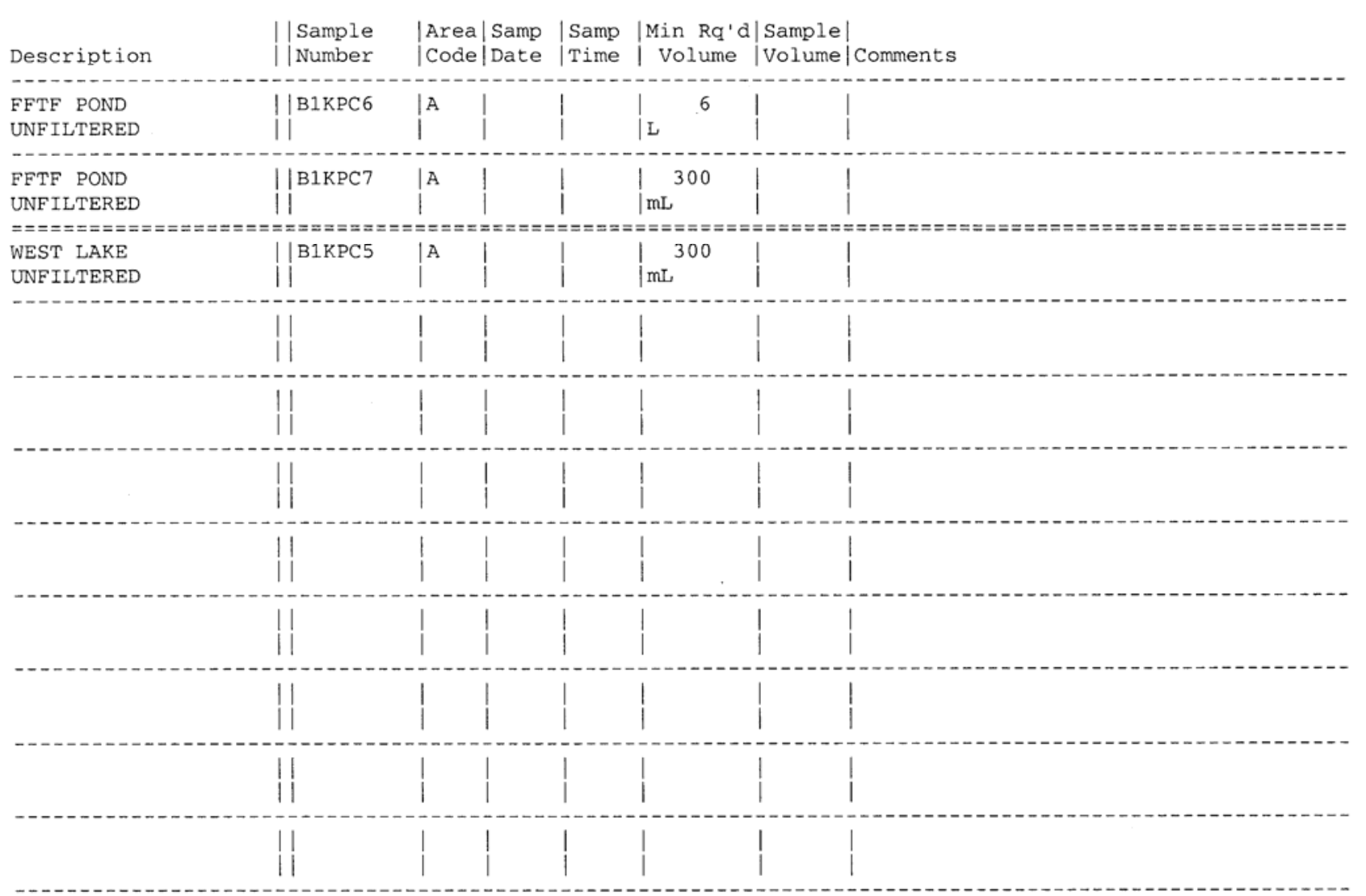

Reling. By:

Reling. To

Relinq. By:

Relinq. To

Relinq. By:

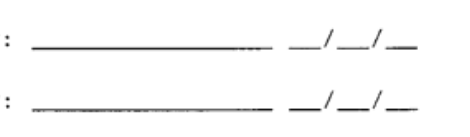

Reling. To

Reviewed By:

(PNL) -'-

Figure 8.1.3. Chain-of-Custody Form for Water Grab Samples 
Route: 01 Lab: STLRL Contract \#3211-A-B2 Battelle - F89148 Sched Date: WEDNESDAY 01/17/2007 Collected By (print):

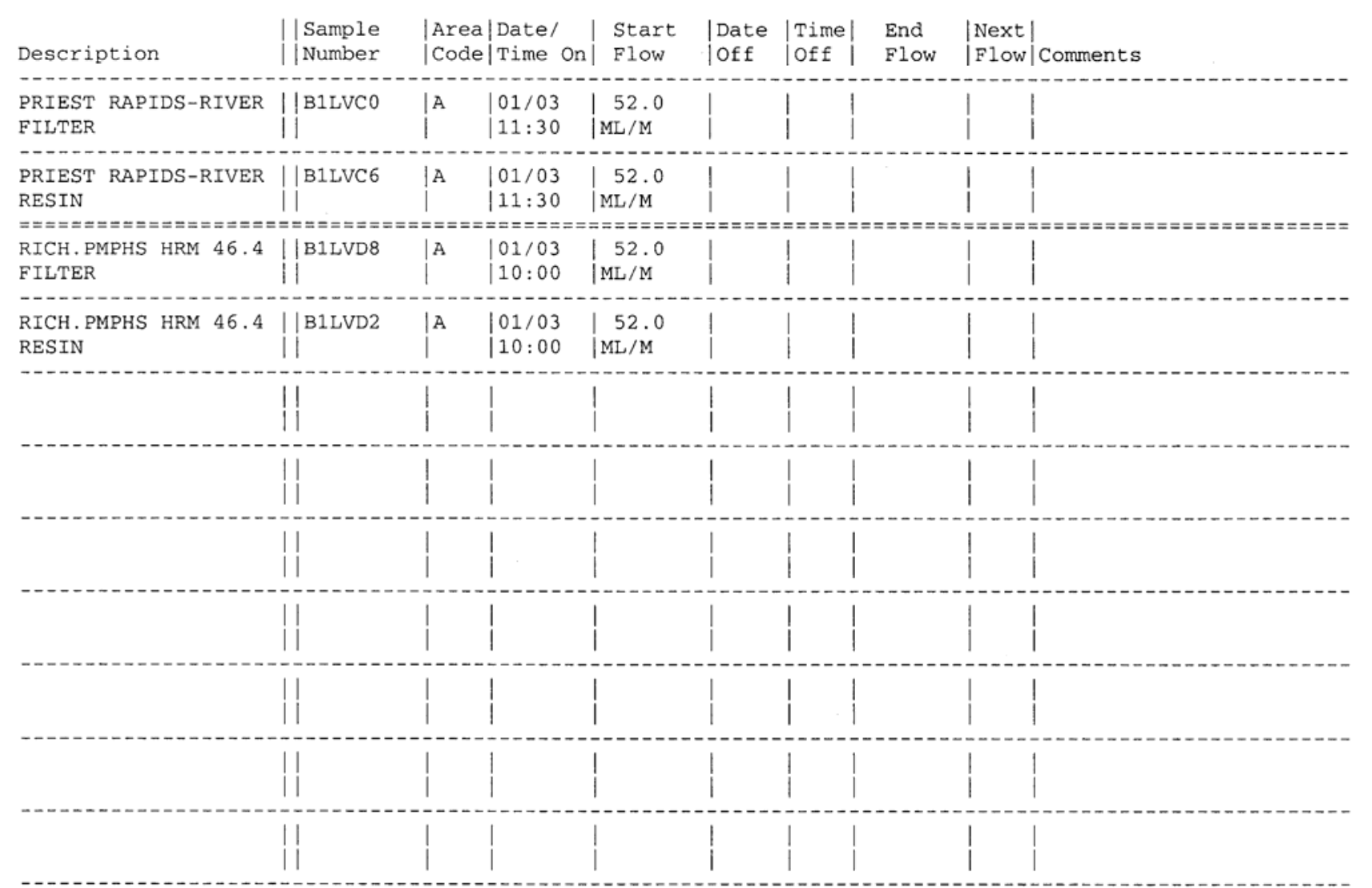

Relinq. By:

Relinq. To

Relinq. By: Relinq. To

Reling. By:

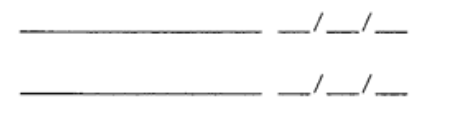

Relinq. To

-

Reviewed By:

( PNL

Figure 8.1.4. Chain-of-Custody Form for Continuous Water Samples 
Route: 8 Lab: STLRL Contract \#3211-A-B2 Battelle - F89155 Balance ID \# Sched Date: MONDAY 01/22/2007 Collected By (print):

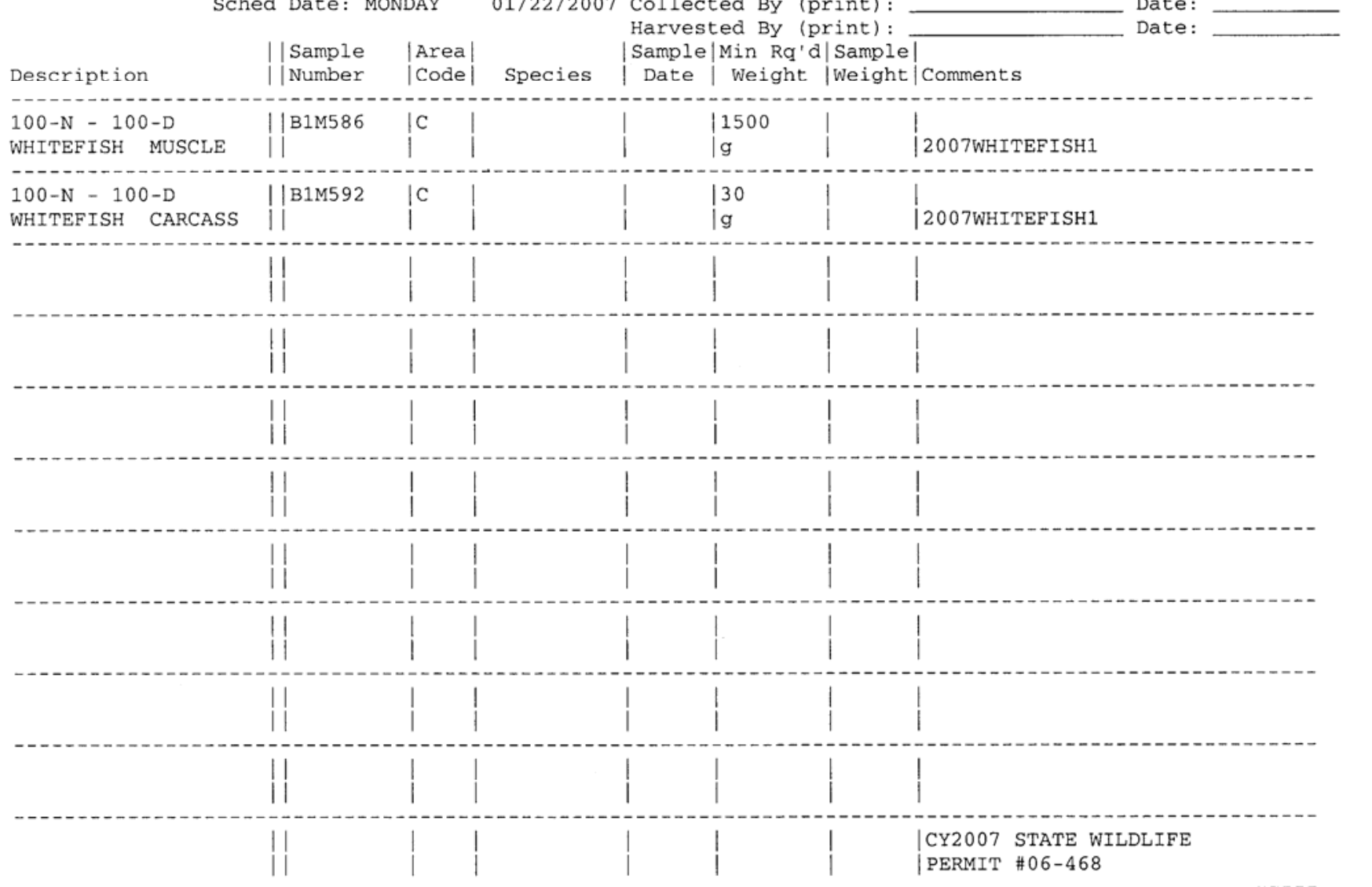

Relinq. By:

Relinq. To

Relinq. By :

Relinq. To

Relinq. By : (PNL)

Figure 8.1.5. Chain-of-Custody Form for Wildlife Samples 
Route: 1 Lab: STLRL Contract \#3211-A-B2 Battelle - F71289 Balance ID \#

Sched Date: FRIDAY 07/07/2006 Collected By (print):

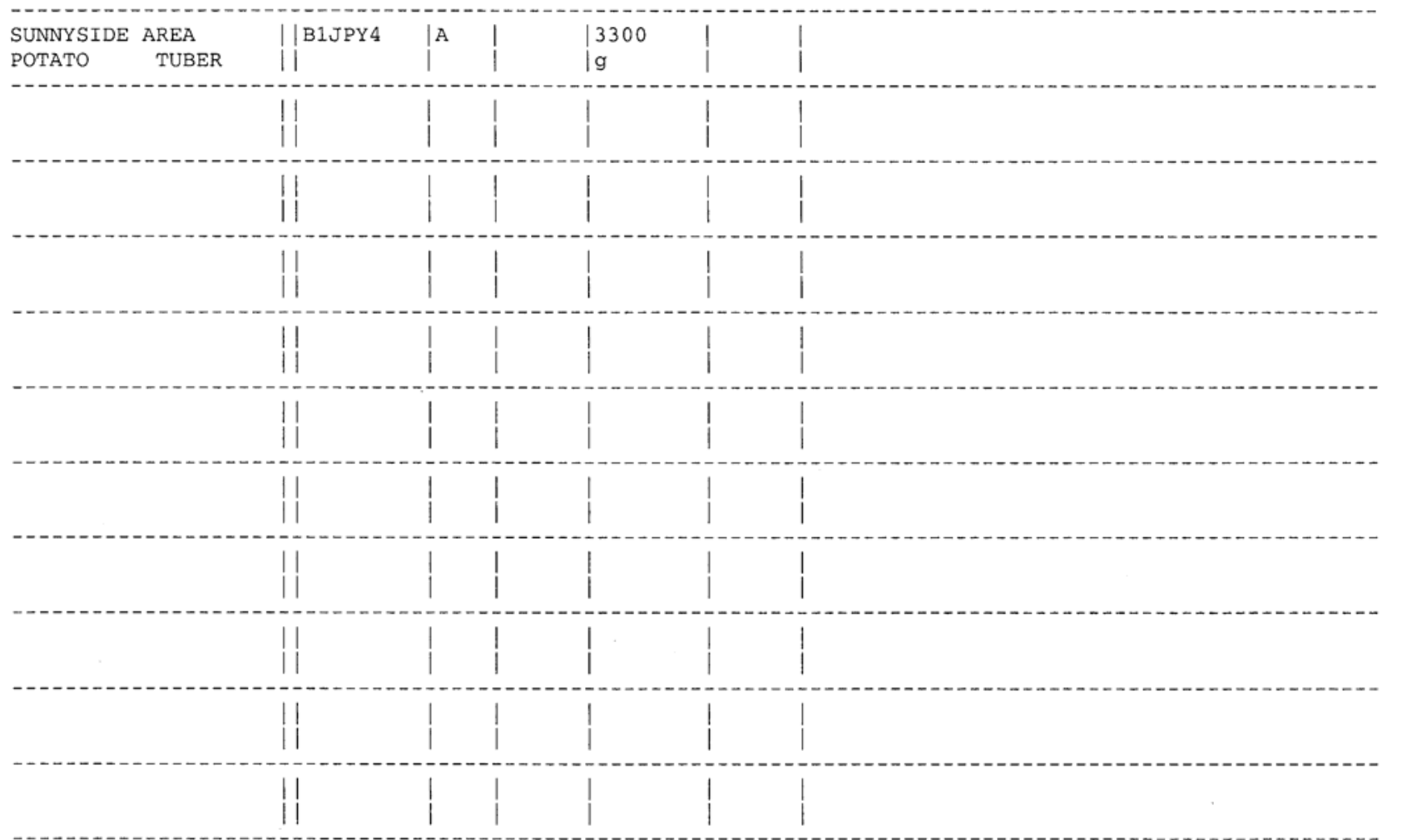

Relinq. By:

Reling. By:

Relinq. By:

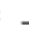

Reviewed By:

(PNL)
Relinq. To

Reling. To

eling. To

$-^{\prime}-1$

Figure 8.1.6. Chain-of-Custody Form for Food and Farm Product Samples, Soil and Vegetation Samples, and Sediment Samples 
Section 8.1

Issued: 02-07

Supersedes: 12-02

PNL-MA-580

Page 14

\section{STLRL Daily Trip Log Report}

\begin{tabular}{llllll}
\hline \multicolumn{1}{c}{ THURSDAY } & & 01/18/2007 & ROUTE: & \\
\hline SAMP\# & COMPOSITE\# & TUID & $\underline{\text { SPECIFIC MEDIA }}$ & $\underline{\text { CON GROUP NAME }}$ & $\underline{\text { LAB }}$ \\
B1LV78 & B1LV77 & F89144 & FILTER1 & AIR_BETA & STLRL \\
B1LW33 & B1LW32 & F89144 & FILTER1 & AIR_ALPHA,AIR_BETA & STLRL \\
B1LW39 & B1LW32 & F89144 & FILTER1 & AIR_ALPHA,AIR_BETA & STLRL \\
B1M574 & & F89144 & SILICA_GEL_HTO & AIR_H_3 & STLRL \\
B1LW52 & B1LW45 & F89144 & FILTER1 & AIR_ALPHA,AIR_BETA & STLRL \\
B1LW89 & B1LW88 & F89144 & FILTER1 & AIR_ALPHA,AIR_BETA & STLRL \\
B1M575 & & F89144 & SILICA_GEL_HTO & AIR_H_3 & STLRL \\
B1LW46 & B1LW45 & F89144 & FILTER1 & AIR_ALPHA,AIR_BETA & STLRL
\end{tabular}

Figure 8.1.7. Daily Trip Log Report 


\subsection{RADIATION WORK PERMITS}

Radiological Work Permits (RWPs) are occasionally used or encountered (e.g., BC Cribs area) when conducting some environmental monitoring tasks on the Hanford Site. Depending on the sampling or work location, RWPs may be issued by any of several contractors on the site. If unsure of the radiological status of a specific area or the applicability of an RWP, stay out of the area until the applicability or status can be determined.

- Regardless of the issuing contractor, all SESP sample collection personnel must read, understand, and comply with the requirements of all applicable RWPs.

- Whenever possible, RWP requirements for a specific sampling or work area should be identified prior to conducting field operations. All RWP requirements that impact the ability of sample collection personnel to conduct their work should be brought to the attention of the sample collection task leader or the appropriate media task leader as soon as possible.

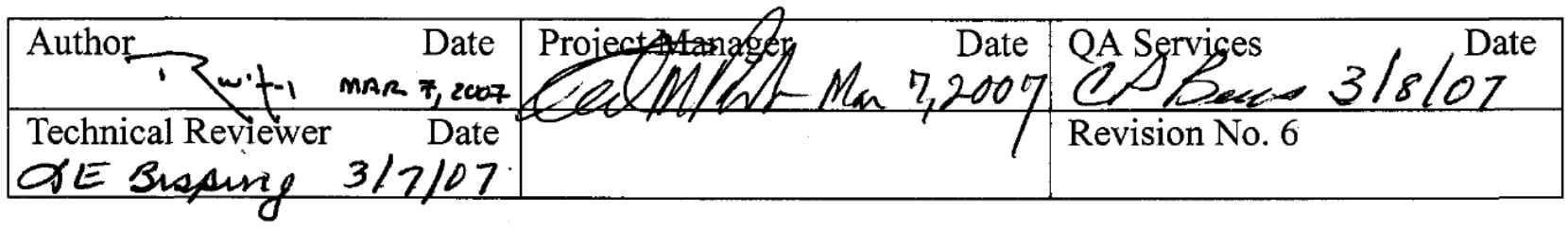




\subsection{RADIOLOGICAL SURVEYS OF SAMPLES}

Radiological surveys of SESP samples collected on and off the Hanford Site are only necessary when:

- Samples are collected from a posted radiological zone.

- Wildlife samples are collected near the 200 Areas.

- $\quad$ Surveys are required by SESP or PNNL management.

- $\quad$ Surveys are required by PNNL, federal, state, or site contractor regulations.

PNNL only requires surveys when samples are collected in a posted radiological zone or when sample collection personnel suspect the presence of radiological contamination.

The SESP requires that all wildlife samples collected in close proximity to the 200-East and 200-West Areas be surveyed for radiological contaminants. These surveys must be documented on the chain-of-custody form in the comment column. If animal survey readings are above area background readings, the animal will be considered contaminated and one of the people listed below must be contacted for instructions before the animal is transported or processed. Attempt to contact them in the order shown. Telephone (land line) or personal contact is preferred. However, a cellular telephone may be used to establish initial contact. Minimize discussion of contamination levels over the cellular telephone.

- Amanda Stegen, SESP wildlife task manager, 372-4511.

- $\quad$ Bill Hanf, SESP sample collection task manager, 371-7107.

- $\quad$ Lynn Bisping, SESP data management task manager, 371-7121.

- $\quad$ Ted Poston, SESP manager, 371-7068.

\begin{tabular}{|c|c|c|}
\hline $\begin{array}{l}\text { Author } \\
1 Z_{w} \cdot t-1 \quad \text { Apr 27, } 2007\end{array}$ & 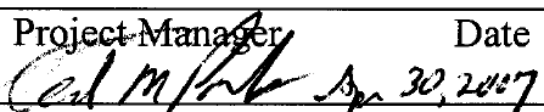 & QA Serviges $5 / 7107$ \\
\hline $\begin{array}{l}\text { Technical Revlewer Date } \\
\text { XEB Buning 5/3/D7 }\end{array}$ & & Revision No. 8 \\
\hline
\end{tabular}




\subsection{USING FIREARMS}

\begin{tabular}{|c|c|}
\hline INTRODUCTION & $\begin{array}{l}\text { Firearms (rifle and shotgun) are used by SESP personnel to collect } \\
\text { selected wildlife samples on and around the Hanford Site. Project } \\
\text { firearms and ammunition are stored in a locked gun safe located in the } \\
\text { office of the SESP firearms custodian. The key to this office is only } \\
\text { available from the custodian, technical group leader of the } \\
\text { Environmental Characterization and Risk Assessment Group, and } \\
\text { PNNL Operations Center. } \\
\text { Only the custodian and the backup custodian have access to the gun } \\
\text { safe. Wildlife collections using firearms must be planned in advance to } \\
\text { ensure access to the custodian's office and that the custodian or the } \\
\text { backup custodian is available to open the safe and issue the firearms } \\
\text { when they are needed, and return them to locked storage at the end of } \\
\text { the day. }\end{array}$ \\
\hline NOTIFICATIONS & $\begin{array}{l}\text { If sampling onsite, advance notice of firearms use must be given to } \\
\text { selected Hanford Site contractors so that they can tell workers in the } \\
\text { collection areas that they may hear gunshots. This notification is done } \\
\text { by the SESP sample collection task leader. } \\
\text { On the day of collection, the collection crew must notify the PNNL } \\
\text { Operations Center (email at ^PNNL Operations Center; phone } \\
\text { 375-2154 or 375-2400) of their intended activities. If collecting onsite, } \\
\text { they must also notify the Hanford Patrol (email at ^Patrol Operations } \\
\text { Center; phone 373-3800). Notifications should include the names of } \\
\text { the collection crew, the collection locations and estimated collection } \\
\text { times, the kind of sampling that is being done (e.g., deer sampling), and } \\
\text { the type of firearm and ammunition being used. A field-crew contact } \\
\text { name and cell phone number should also be provided. If onsite } \\
\text { collections require access through a manned barricade (e.g., the Wye } \\
\text { Barricade), the field crew must notify the patrol officer at the barricade } \\
\text { that they are transporting a weapon and ammunition. The field crew } \\
\text { must notify the PNNL Operations Center and the Patrol Operations } \\
\text { Center, as appropriate, when collection efforts are completed. }\end{array}$ \\
\hline $\begin{array}{l}\text { SAFETY ITEMS } \\
\text { REQUIRED WHEN } \\
\text { USING FIREARMS }\end{array}$ & $\begin{array}{l}\text { Items required when collecting wildlife samples with firearms include: } \\
\text { - Cell phone with a charged battery. }\end{array}$ \\
\hline
\end{tabular}

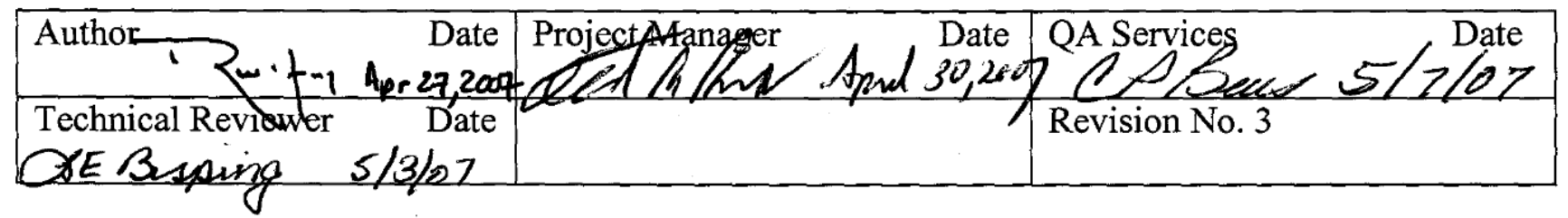




\begin{tabular}{|c|c|}
\hline & $\begin{array}{l}\text { - Hunters-orange safety vests. } \\
\text { - } \quad \text { List of emergency contact phone numbers. } \\
\text { - } \quad \text { Emergency first aid kit (in the vehicle). } \\
\text { - } \quad \text { Hearing protection (glasses or safety glasses). } \\
\text { - Hection. }\end{array}$ \\
\hline $\begin{array}{l}\text { OTHER REQUIRED } \\
\text { ITEMS }\end{array}$ & $\begin{array}{l}\text { Other items needed for wildlife sampling include: } \\
\text { - } \quad \text { State and federal game collection permits. } \\
\text { - DOE Prohibited Articles pass for firearms and ammunition (if } \\
\text { collecting onsite). }\end{array}$ \\
\hline USING FIREARMS & $\begin{array}{l}\text { No one will use a SESP firearm until they have taken the PNNL } \\
\text { firearms safety training course and have had hands-on training (firing } \\
\text { range) with the firearm being used. This training is an annual } \\
\text { requirement. The SESP firearms safety protocol will be read } \\
\text { immediately prior to the use of any PNNL firearm. } \\
\text { Collection personnel who are using medications that could potentially } \\
\text { impair motor skills or judgment are not to use SESP firearms unless } \\
\text { they are authorized to do so by a physician. } \\
\text { For safety reasons, SESP wildlife collections with firearms will almost } \\
\text { always involve at least two people working together. The only } \\
\text { exception to this rule involves the use of a firearm to dispatch a small } \\
\text { animal (e.g., rabbit) that has been collected in a trap. When a trap is } \\
\text { used, one person may use a small caliber rifle to dispatch the trapped } \\
\text { animal. However, immediately prior to discharging the firearm the } \\
\text { person using the firearm must notify (by cell phone) the PNNL } \\
\text { Operations Center (375-2154 or } 375-2400 \text { ) to let them know the firearm } \\
\text { will be used, and call them again immediately after the use of the } \\
\text { firearm to let them know that all is well. } \\
\text { All persons in the collection team will wear hunters-orange safety vests } \\
\text { when collections are conducted. } \\
\text { All persons using firearms will wear ear and eye protection when } \\
\text { collections are conducted. }\end{array}$ \\
\hline
\end{tabular}


STORING FIREARMS AND AMMUNITION
All SESP firearms are stored unloaded in a locked cabinet. Firearms must be obtained from the firearms custodian who will sign the firearm out to the collector. The sign-out sheet is located in the gun cabinet. When removing any firearm from the storage cabinet, check the firearm to verify that it is unloaded, clean, and free of obstructions. Leave the firearm action open.

Put the firearm in a case for transport.

Following wildlife collection efforts, the firearm will be cleaned by the collector upon return from the field, or arrangements will be made to clean the firearm within a reasonable amount of time after its use. Firearm cleaning supplies can be obtained from the firearms custodian, who may also furnish assistance.

A firearm will be removed from its case before being returned to the storage cabinet.

Before putting the firearm into storage again check to see that it is unloaded and the action is open.

The firearm custodian will sign the firearm back into storage. The firearm sign-in sheet is kept in the storage cabinet.

All unused ammunition will be returned to the firearm custodian.

Any malfunctioning firearm shall be tagged and reported to the firearm custodian. It will be the firearm custodian's responsibility to see that it is repaired. Do not bring a malfunctioning firearm containing live ammunition into a building, and seek instruction from PNNL Worker Safety and Health (Drue Collins, 375-3750) before transporting a firearm in this condition in a vehicle.

Ammunition that has misfired or is damaged will be given to the firearm custodian for proper disposal.

USING FIREARMS

At no time will a loaded firearm be allowed in a building or vehicle without authorization from PNNL Worker Safety and Health.

Upon approach and arrival to the collection area, assure that the collection area is clear of other personnel, vehicles, or structures and be constantly alert for changing conditions.

Prior to loading any firearm, the chamber and the barrel shall again be checked to ensure the firearm is free from obstructions. 
Section 8.4

Issued: 05-07

\begin{tabular}{|l|l|}
\hline $\begin{array}{l}\text { While walking with a loaded firearm, the user will at all times keep the } \\
\text { firearm safety on and the firearm pointed in a safe direction. Ensure } \\
\text { that the background is clear before shooting. }\end{array}$ \\
$\begin{array}{l}\text { Immediately after use, the firearm will be put into a safe condition and } \\
\text { unloaded. It will not be placed in a case or vehicle until it has been } \\
\text { unloaded. }\end{array}$ \\
\hline
\end{tabular}




\subsection{DETERMINING GEOGRAPHIC POSITIONS}

\begin{tabular}{|c|c|}
\hline INTRODUCTION & $\begin{array}{l}\text { A geographic positioning system (GPS) instrument can determine real- } \\
\text { time positions (latitude/longitude coordinates) with an accuracy of } \\
\text { approximately } \pm 3 \text { meters. Included here are the procedures needed to } \\
\text { measure and record the coordinates of project sampling locations using a } \\
\text { Garmin eTrex Legend. For more detailed instructions on using the Garmin } \\
\text { eTrex Legend, refer to Garmin’s user’s guide. }\end{array}$ \\
\hline PERSONNEL & $\begin{array}{l}\text { GPS measurements must be collected by people who have received } \\
\text { training on these procedures and the instrument user's guide, and have had } \\
\text { hands-on training with the GPS instrument. } \\
\text { This procedure requires one (1) person for efficient operation. }\end{array}$ \\
\hline $\begin{array}{l}\text { EQUIPMENT AND } \\
\text { SUPPLIES }\end{array}$ & $\begin{array}{l}\text { The following equipment and supplies may be needed for the collection of } \\
\text { GPS coordinates: } \\
\text { - Garmin eTrex Legend GPS instrument. } \\
\text { - } \quad \text { Exarmin eTrex Legend users guide. } \\
\text { - Chain-of-custody form. } \\
\text { - Pen/pencil. }\end{array}$ \\
\hline $\begin{array}{l}\text { DATA } \\
\text { COLLECTION }\end{array}$ & $\begin{array}{l}\text { Proceed to the sampling location. } \\
\text { Turn the eTrex Legend on (power button is on the right side) and allow } \\
\text { unit to boot up. } \\
\text { Once the eTrex Legend has determined the location, the latitude/longitude } \\
\text { coordinates will be shown at the bottom of the "Satellite" page (you may } \\
\text { need to scroll through the pages with the Page button (Figure 8.5.1) until } \\
\text { the "Satellite" page is displayed). Record the coordinate information on } \\
\text { the chain-of-custody form in the description column, or to the left of the } \\
\text { sampling location name that is in the description column. If latitude and } \\
\text { longitude are not displayed in decimal degrees, refer to the configurations } \\
\text { section below. }\end{array}$ \\
\hline
\end{tabular}

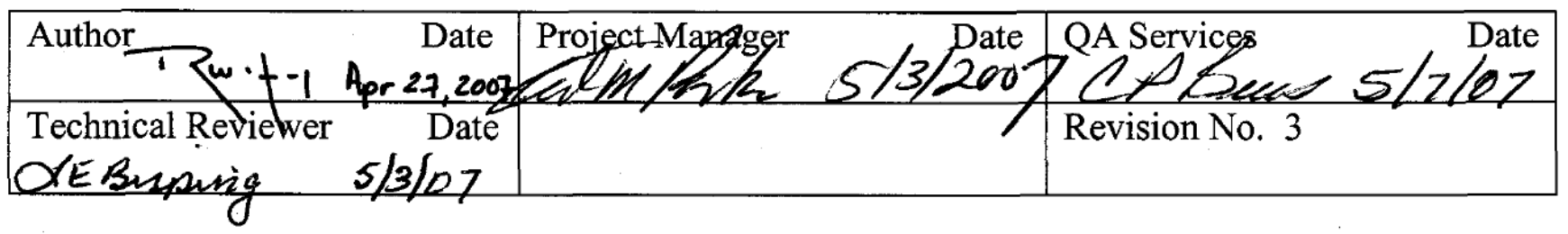




\begin{tabular}{|c|c|}
\hline $\begin{array}{l}\text { CHECK } \\
\text { CONFIGURATION } \\
\text { SETTINGS }\end{array}$ & $\begin{array}{l}\text { All scrolling/selecting is done with the thumb stick (Figure 8.5.1) } \\
\text { - Press the "Page" button until the "Main Menu" is shown. } \\
\text { - Scroll to "Setup" and press the thumb stick. } \\
\text { - Scroll up and left to the "Units" icon, press the thumb stick. } \\
\text { - Ensure that "Position Format" is set to decimal degrees (hddd.ddddd } \\
\left.\text { [e.g., } 46.678020908^{\circ} \mathrm{N} \text { and }-119.462893663^{\circ} \mathrm{E}\right] \text { ) and "Map Datum" } \\
\text { is set to WGS } 84 .\end{array}$ \\
\hline SHUTTING DOWN & $\begin{array}{l}\text { To turn the eTrex Legend off, press and hold the Power button } \\
\text { (Figure 8.5.1) for approximately } 3 \text { seconds. }\end{array}$ \\
\hline
\end{tabular}




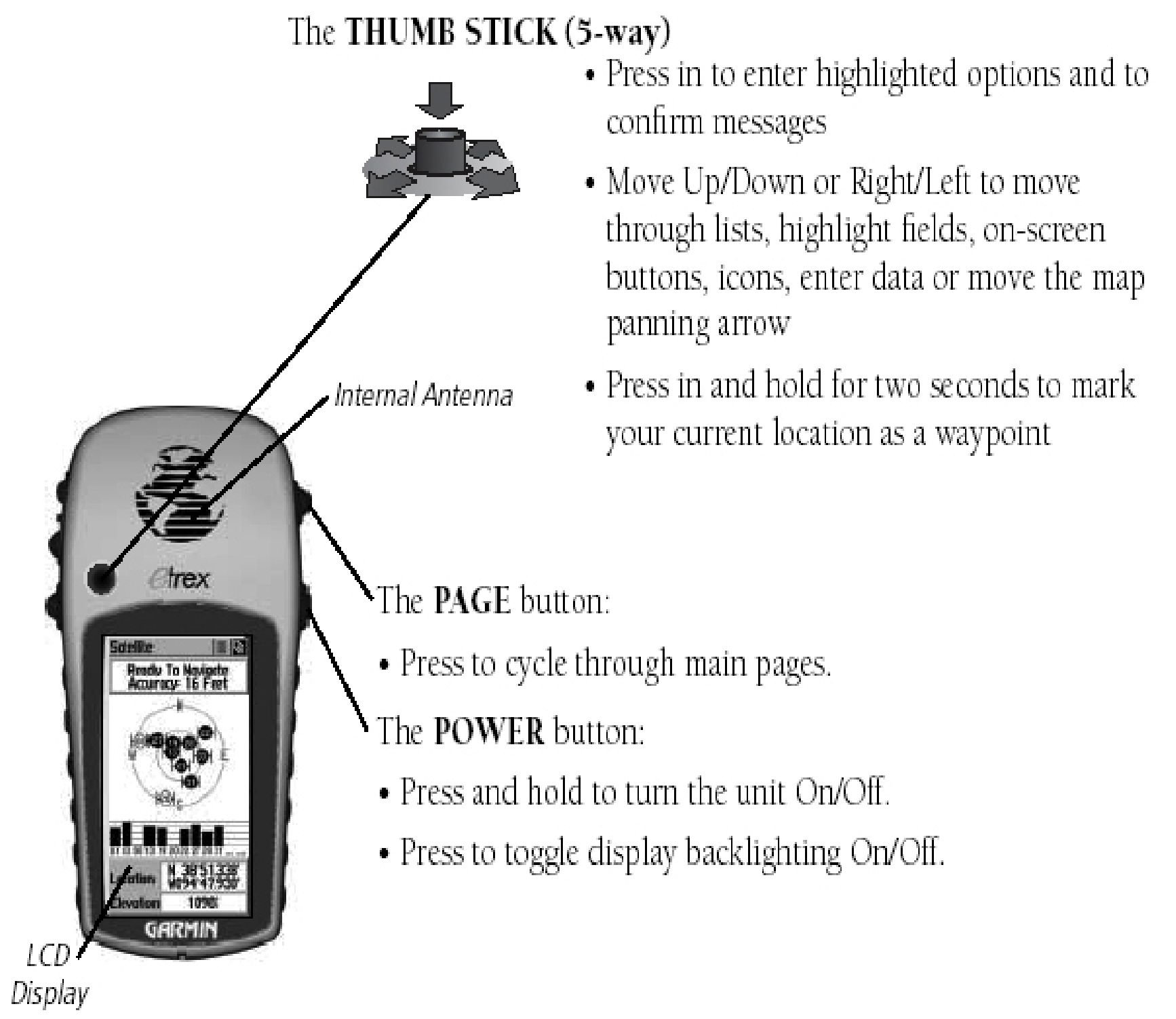

Figure 8.5.1. Instructions for Using the Garmin eTrex Legend (illustration from the Garmin Users Guide) 


\subsection{JOB SAFETY ANALYSES}

This section includes copies of four Job Safety Analyses (JSAs) that were prepared to document the principle risks and hazards associated with conducting SESP sample collection activities. Included are JSAs for:

- Operation of Boats

- Environmental Sampling

- Using Firearms

- Operation of Electrofisher

These JSA copies are included here so that they are easily accessible to project personnel. The signed/dated documents are filed in the office of the SESP sample collection task leader.

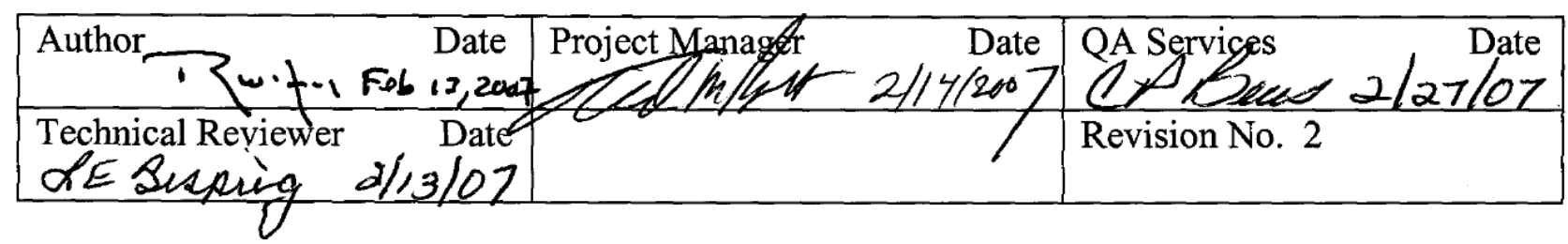




\subsection{OPERATION OF BOATS}

Boats are used for collecting water and sediment samples, fish and wildlife samples, and for transporting people. Only PNNL personnel with Coast Guard Auxiliary or Power Squadron certification, PNNL boat-specific training, and PNNL or SESP management approval are permitted to function as boat operators.

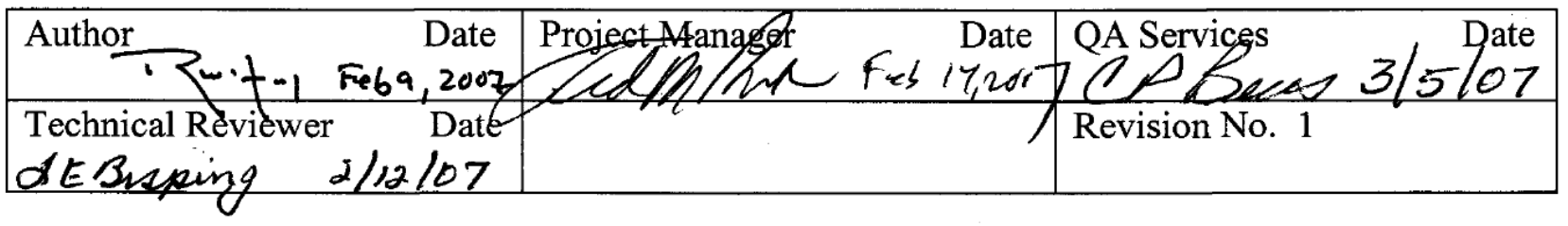


Section 9.1

Issued: 02-07

Supersedes: 11-03

PNL-MA-580

Page 3

\begin{tabular}{|c|c|c|c|c|c|c|c|}
\hline \multirow{2}{*}{\multicolumn{2}{|c|}{$\begin{array}{l}\text { JOB SAFETY } \\
\text { ANALYSIS } \\
\end{array}$}} & \multicolumn{4}{|c|}{ Job Description: Operation of Boats } & \multicolumn{2}{|c|}{ JSA Number: SESP-2 } \\
\hline & & \multicolumn{4}{|c|}{ Component: Env. Characterization \& Risk Assessment Group } & \multicolumn{2}{|c|}{ Building/Area: S5/RCHN } \\
\hline & & \multicolumn{4}{|c|}{ Prepared By: R.W. (Bill) Hanf } & \multicolumn{2}{|c|}{ Date: $01 / 19 / 2007$} \\
\hline WS\&H approval: & Date: & $\begin{array}{l}\text { EC\&RA Group Manager } \\
\text { approval: }\end{array}$ & Date: & Reviewed by: & Date: & & \\
\hline \multicolumn{2}{|c|}{$\begin{array}{c}\text { SAFETY EQUIPMENT } \\
\text { REQUIRED } \\
\end{array}$} & \multicolumn{2}{|c|}{$\begin{array}{c}\text { TOOLS AND EQUIPMENT } \\
\text { REQUIRED } \\
\end{array}$} & \multicolumn{4}{|c|}{ JOB PREPARATION } \\
\hline \multirow{3}{*}{\multicolumn{2}{|c|}{$\begin{array}{l}\text { See "Pre-Trip Preparation } \\
\text { Checklist" on pages } 5 \& 6 .\end{array}$}} & \multicolumn{2}{|c|}{$\begin{array}{l}\text { See "Pre-Trip Preparation } \\
\text { Checklist" on pages } 5 \text { \& } 6 \text {. } \\
\text { Additional tools required on the } \\
\text { ThunderJet include large bolt } \\
\text { cutters and a rake for cleaning } \\
\text { debris from the jet-drive intake } \\
\text { screen. }\end{array}$} & \multicolumn{4}{|c|}{$\begin{array}{l}\text { Pre-plan trip, (see attached checklist). Inspect } \\
\text { tow vehicle, boat, boat trailer, and equipment } \\
\text { prior to leaving the staging area. Make sure } \\
\text { that life jackets for each crew member and } \\
\text { passenger are available and that other safety } \\
\text { items are accounted for. Fire extinguisher } \\
\text { should be fully charged. Only PNNL personnel } \\
\text { with Coast Guard Auxiliary or Power Squadron } \\
\text { certification, PNNL boat specific checkout } \\
\text { training, and PNNL and/or SESP management } \\
\text { approval are permitted to function as boat } \\
\text { operators. Notify the PNNL Operations Center } \\
\text { (375-2154, email at } \wedge \text { PNNL Operations Center) } \\
\text { that PNNL staff will be on the river. Include a } \\
\text { float plan with this notification. An example of } \\
\text { a float plan is provided on page } 7 \text {. This form } \\
\text { can be obtained electronically at } \\
\text { http://sbms.pnl.gov/standard/1m/1m06e020.dot } \\
\text { ?pos=1. Float plan information can also be } \\
\text { provided to the PNNL Operations Center less } \\
\text { formally in an email format. }\end{array}$} \\
\hline & & \multicolumn{2}{|c|}{ HAZARDOUS MATERIALS } & \multicolumn{4}{|c|}{ RELATED REQUIREMENTS } \\
\hline & & \multicolumn{2}{|l|}{$\begin{array}{l}\text {-Gasoline } \\
\text {-Oil } \\
\text {-Batteries }\end{array}$} & \multicolumn{4}{|c|}{$\begin{array}{lcc}\text { Radiation Work Procedure } & \text { Yes } & \text { No X } \\
\text { Nuclear Safety Specification } & \text { Yes } & \text { No X }\end{array}$} \\
\hline \multicolumn{2}{|c|}{ JOB STEP } & \multicolumn{2}{|c|}{ HAZARD } & \multicolumn{4}{|c|}{$\begin{array}{c}\text { HAZARD CONTROL AND PROTECTIVE } \\
\text { EQUIPMENT } \\
\end{array}$} \\
\hline \multicolumn{2}{|c|}{$\begin{array}{l}\text { BOATING } \\
\text { OPERATIONS }\end{array}$} & & & \multicolumn{4}{|c|}{$\begin{array}{l}\text { Comply with Boat Operations requirements at } \\
\text { http://sbms.pnl.gov/standard/1m/1m00t010.htm, } \\
\text { and with the rules and regulations in the } \\
\text { Washington State boater's handbook } \\
\text { (http://www.boat-ed.com/wa/handbook.) A } \\
\text { minimum of two persons must be on board the } \\
\text { boat. One of the people must be trained in first } \\
\text { aid and cardio-pulmonary resuscitation (CPR). }\end{array}$} \\
\hline
\end{tabular}




\begin{tabular}{|c|c|c|}
\hline JOB STEP & HAZARD & $\begin{array}{c}\text { HAZARD CONTROL AND PROTECTIVE } \\
\text { EQUIPMENT } \\
\end{array}$ \\
\hline $\begin{array}{l}\text { HITCHING AND } \\
\text { TOWING THE BOAT }\end{array}$ & $\begin{array}{l}\text { Hitch failure, affect of boat and } \\
\text { trailer weight on vehicle braking } \\
\text { and acceleration, impaired } \\
\text { visibility, bad trailer wheel } \\
\text { bearings, rough roads, equipment } \\
\text { malfunction, turning too sharply } \\
\text { with trailer }\end{array}$ & $\begin{array}{l}\text { Use the appropriate sized tow vehicle for the } \\
\text { boat. } \\
\text { Assure that the boat trailer is properly secured } \\
\text { to the tow vehicle. Check that the trailer lights } \\
\text { are operational, that safety chains and boat tie- } \\
\text { downs are in place, that the boat hitch is on the } \\
\text { ball properly and is locked down, and that tires } \\
\text { are properly inflated. } \\
\text { Allow extra distance for stopping and } \\
\text { accelerating and check carefully before making } \\
\text { lane changes. } \\
\text { Excessive speed can cause the trailer to whip. } \\
\text { Drive conservatively. } \\
\text { When traveling on rough roads, slow down. } \\
\text { Excessive speed on bumpy roads can cause the } \\
\text { trailer tongue to separate from the vehicle hitch. } \\
\text { Watch for overheated trailer wheel bearings } \\
\text { while towing (i.e., look for smoke or leaking } \\
\text { grease). }\end{array}$ \\
\hline $\begin{array}{l}\text { LAUNCHING AND } \\
\text { STARTING THE BOAT }\end{array}$ & $\begin{array}{l}\text { Backing over someone or } \\
\text { something, backing too far into } \\
\text { the water, getting stuck, } \\
\text { launching the boat prematurely, } \\
\text { unattended tow vehicle rolling } \\
\text { down the boat ramp and into the } \\
\text { water, slipping and falling, losing } \\
\text { control of winch handle when } \\
\text { catch is released, explosion, fire }\end{array}$ & $\begin{array}{l}\text { Many launch area problems can be avoided if } \\
\text { other available crewmembers assist the tow } \\
\text { vehicle driver when launching the boat. } \\
\text { Verify that the boat drain plug is in place and } \\
\text { that cooling system petcocks (if present) are } \\
\text { closed. } \\
\text { Make sure that the jet boat intake is free of } \\
\text { debris. } \\
\text { Make sure that the battery is turned on. } \\
\text { Unimproved shoreline launch sites can be } \\
\text { slippery and/or rough. When launching at these } \\
\text { sites, put the tow vehicle into 4-wheel drive } \\
\text { before launching the boat. } \\
\text { Disconnect the trailer lights from the tow } \\
\text { vehicle before backing the trailer into the water. } \\
\text { Hot light bulbs break when exposed to cold } \\
\text { water. Remember to reconnect the lights after } \\
\text { the boat is removed from the water. }\end{array}$ \\
\hline
\end{tabular}




\begin{tabular}{|c|c|c|}
\hline JOB STEP & HAZARD & $\begin{array}{c}\text { HAZARD CONTROL AND PROTECTIVE } \\
\text { EQUIPMENT }\end{array}$ \\
\hline $\begin{array}{l}\text { LAUNCHING AND } \\
\text { STARTING THE BOAT } \\
\text { (CONT) }\end{array}$ & & $\begin{array}{l}\text { Don't undo the bow line until the boat is partly } \\
\text { in the water. Releasing the bow line too early } \\
\text { could result in the boat sliding off the trailer } \\
\text { prematurely. } \\
\text { Before backing up, walk behind the boat and } \\
\text { check for obstructions or potential problems. } \\
\text { Let people in the immediate area know of your } \\
\text { intention to move the vehicle. Back up slowly } \\
\text { until the boat is in the water far enough to start } \\
\text { the boat engines. If the tow vehicle driver } \\
\text { needs to leave the vehicle, he/she should leave } \\
\text { the vehicle in park with the emergency brake } \\
\text { set. } \\
\text { Be aware that the winch line is under stress. } \\
\text { Use care when releasing the winch lock and } \\
\text { hold the winch handle securely so that the } \\
\text { winch does not free-wheel unexpectedly. } \\
\text { The boat should not be pushed or bumped from } \\
\text { the trailer until the boat driver indicates that } \\
\text { he/she is ready. } \\
\text { Launching from primitive shoreline areas may } \\
\text { require backing the truck up until its exhaust is } \\
\text { in the water. Do not shut the truck engine off } \\
\text { when the exhaust pipe is under water. The } \\
\text { engine could be damaged and the truck may not } \\
\text { restart. } \\
\text { At any launch site be aware that wet, muddy } \\
\text { surfaces can be very slippery. Walk carefully } \\
\text { at all times. } \\
\text { Never smoke or light a match when starting } \\
\text { boat engines. Allow the engine compartment } \\
\text { fan to run at least } 5 \text { minutes prior to starting the } \\
\text { engine to remove any potentially explosive } \\
\text { gases. If possible, remove the cover to the } \\
\text { engine compartment for additional venting. } \\
\text { Be sure that battery caps are tight to prevent } \\
\text { explosive hydrogen gases from escaping. } \\
\text { Check and close all drain petcocks on the } \\
\text { engine. Start the engines with the transmission } \\
\text { in neutral. } \\
\text { extinguishers. }\end{array}$ \\
\hline
\end{tabular}




\begin{tabular}{|c|c|c|}
\hline JOB STEP & HAZARD & $\begin{array}{c}\text { HAZARD CONTROL AND PROTECTIVE } \\
\text { EQUIPMENT } \\
\end{array}$ \\
\hline $\begin{array}{l}\text { BOARDING OR } \\
\text { DISEMBARKING FROM } \\
\text { THE BOAT AND } \\
\text { LOADING AND } \\
\text { UNLOADING } \\
\text { EQUIPMENT }\end{array}$ & Falling, drowning, back strain & $\begin{array}{l}\text { Board the boat carefully. Surfaces can be } \\
\text { slippery and unstable. Make sure the boat is } \\
\text { securely moored or beached. If boarding a } \\
\text { small boat, keep your center of gravity low and } \\
\text { toward the center of the boat. Putting too much } \\
\text { weight to one side or the other could cause the } \\
\text { boat to tip. } \\
\text { If lifting and/or loading heavy equipment, do } \\
\text { not attempt to do it alone. Do not lift while } \\
\text { standing in an awkward position. }\end{array}$ \\
\hline GETTING UNDERWAY & Falling, drowning & $\begin{array}{l}\text { In most boats, life jackets must be worn at all } \\
\text { times while on the water. In the ThunderJet, } \\
\text { life jackets must be worn when outside of the } \\
\text { boat cabin. } \\
\text { All jet boat passengers should wear hearing } \\
\text { protection when the ThunderJet engine is } \\
\text { operating above idle (optional). } \\
\text { Equipment must be stored neatly and securely } \\
\text { and weight should be evenly distributed. } \\
\text { If passengers are unfamiliar with the boat, } \\
\text { conduct a briefing on boat safety and } \\
\text { requirements. } \\
\text { Cast off mooring lines on the instruction of the } \\
\text { boat driver only. } \\
\text { Before moving the boat, the operator should } \\
\text { assure that all passengers are positioned } \\
\text { properly and are warned that the boat will start. }\end{array}$ \\
\hline BOAT DRIVING & $\begin{array}{l}\text { Falling, drowning, capsizing or } \\
\text { tipping the boat, running } \\
\text { aground, losing or grounding the } \\
\text { boat along the shoreline, } \\
\text { colliding with another boat, } \\
\text { running into or over floating } \\
\text { debris, encountering aquatic } \\
\text { vegetation }\end{array}$ & $\begin{array}{l}\text { Avoid abrupt starts and stops. Keep the deck } \\
\text { clear of unnecessary materials. Pay attention to } \\
\text { the conditions around you and drive at a } \\
\text { reasonable and safe speed for those conditions. } \\
\text { Observe the boating navigation rules outlined } \\
\text { in the state boaters guide, when operating } \\
\text { around other boats. } \\
\text { Avoid operating in severe weather or high } \\
\text { winds. Check the weather forecast before } \\
\text { departing for the boat launch. }\end{array}$ \\
\hline
\end{tabular}




\begin{tabular}{|c|c|c|}
\hline JOB STEP & HAZARD & $\begin{array}{c}\text { HAZARD CONTROL AND PROTECTIVE } \\
\text { EQUIPMENT } \\
\end{array}$ \\
\hline BOAT DRIVING (CONT) & & $\begin{array}{l}\text { If high waves develop, reduce speed, angle the } \\
\text { bow of the boat into the waves and get off the } \\
\text { water as soon as possible. Avoid positioning } \\
\text { the boat sideways to the waves. If the boat } \\
\text { capsizes or tips, try to stay with the boat until } \\
\text { rescued. } \\
\text { If operating in unfamiliar waters, slow down, } \\
\text { and watch for signs of shallow water or hidden } \\
\text { bars. If possible, use a depth finder to } \\
\text { determine water depth. Approach unfamiliar } \\
\text { shorelines carefully. } \\
\text { Keep all ropes and lines away from the lower } \\
\text { unit of the engine or water intake of the jet } \\
\text { pump. Snagging a lower unit or sucking a rope } \\
\text { or line into the jet pump intake can incapacitate } \\
\text { an engine or, in the right circumstances, cause } \\
\text { a boat to turn backwards into the current and } \\
\text { take on water. } \\
\text { Watch out for navigation hazards including } \\
\text { debris floating on the water surface. On the } \\
\text { Columbia and Snake Rivers debris can be a } \\
\text { problem when river flows increase and } \\
\text { materials that have accumulated on the } \\
\text { shorelines are washed into the river. } \\
\text { When working on the Columbia River, do not } \\
\text { leave a beached boat unattended for very long. } \\
\text { Rapid fluctuations of the river level along the } \\
\text { Hanford Reach could result in a boat being } \\
\text { grounded on the river shoreline. } \\
\text { Always anchor or tie the boat properly at the } \\
\text { shoreline to prevent the boat from floating } \\
\text { downstream if the water level rises. } \\
\text { When using the ThunderJet, or any other boat } \\
\text { with jet-drive, stay away from shoreline areas } \\
\text { infested with aquatic vegetation. Vegetation } \\
\text { will be sucked into the jet-drive intake and will } \\
\text { probably clog up the intake screen and disable } \\
\text { the boat. Even a partial block of the intake } \\
\text { screen will have a significant effect on boat } \\
\text { performance. A clogged intake can be cleaned } \\
\text { with a special "rake" but complete removal of a } \\
\text { blockage may not be possible until the boat is } \\
\text { removed from the water. }\end{array}$ \\
\hline
\end{tabular}




\begin{tabular}{|c|c|c|}
\hline JOB STEP & HAZARD & $\begin{array}{c}\text { HAZARD CONTROL AND PROTECTIVE } \\
\text { EQUIPMENT }\end{array}$ \\
\hline $\begin{array}{l}\text { ANCHORING THE } \\
\text { BOAT }\end{array}$ & $\begin{array}{l}\text { Sinking boat, anchor line in } \\
\text { props or jet-drive intake, anchor } \\
\text { snagging on bottom substrates }\end{array}$ & $\begin{array}{l}\text { Swift currents in the Hanford Reach of the } \\
\text { Columbia River make anchoring a boat in } \\
\text { midstream very dangerous. Use a long anchor } \\
\text { line and always attach the anchor line to the } \\
\text { bow, never to the stern. Securing an anchor } \\
\text { line to the stern of a boat can result in water } \\
\text { rushing over the transom and flooding or } \\
\text { sinking the boat. } \\
\text { When retrieving an anchor in swift currents, } \\
\text { remember that the current and the forward } \\
\text { momentum of the boat can push the anchor and } \\
\text { anchor line towards the engine propellers or jet- } \\
\text { drive intake. Stay downstream of the anchor } \\
\text { line after the anchor is lifted off the river } \\
\text { bottom. Don't attempt to move to another } \\
\text { anchoring location while the anchor is still in } \\
\text { the water. } \\
\text { The anchor can sometimes snag on the river } \\
\text { bottom making retrieval difficult or impossible. } \\
\text { Be careful not to drive over the anchor line } \\
\text { during anchor retrieval operations. If } \\
\text { necessary, pull up as much line as possible, } \\
\text { then sever the line. }\end{array}$ \\
\hline $\begin{array}{l}\text { TRAILERING THE } \\
\text { BOAT }\end{array}$ & $\begin{array}{l}\text { Hand injuries, poor vehicle } \\
\text { traction }\end{array}$ & $\begin{array}{l}\text { Pull out of the water slowly, avoid spinning the } \\
\text { wheels. } \\
\text { Do not stand between boat and tow vehicle } \\
\text { while boat is being driven onto the trailer. The } \\
\text { boat could overrun the trailer. } \\
\text { When using the winch, be careful not to get } \\
\text { fingers or clothing caught in the cable windings } \\
\text { or winch mechanisms. Make sure that the } \\
\text { winch is properly locked and the safety chain is } \\
\text { attached after the boat is on the trailer. } \\
\text { Make sure trailer lights are plugged in before } \\
\text { leaving the launch area. } \\
\text { Notify PNNL Operations Center (375-2154, } \\
\text { e-mail at } \wedge \text { PNNL Operations Center) that } \\
\text { PNNL personnel are off the river. }\end{array}$ \\
\hline
\end{tabular}




\section{Pre-Trip Preparation Checklist}

from PNNL SBMS (http://sbms.pnl.gov/standard/1m/1m02e010.htm)

\section{Before operating the boat, make sure that the following supplies are on board:}

u.S. Coast Guard-approved personal floatation device for each person. Make sure the devices are properly sized and in good condition. For boats 16 feet in length or greater, a type IV throwable floatation device is also required.

- approved, fully charged fire extinguisher(s) with current inspection dates

a bell, whistle (as required), horn, or other sound-generating device

口 visual distress-signaling devices (check expiration dates if flares are used)

口 paddle, oar, or alternate propulsion device

$\square$ anchor and anchor line

a tool kit and spare parts

a any needed charts, tide table, current table, and navigation equipment

口 non-slip soled shoes worn by passengers

ㅁ bucket

a knife

b boat hook

口 first aid kit

\section{Before operating the boat, make sure that:}

a the trailer and tow vehicle lights are operational

a fluid levels (e.g., fuel, oil, radiator) in the tow vehicle and boat are sufficient

a the boat plug is in good condition and in place

a there is extra oil for the outboard

a the tire pressure on the boat trailer and tow vehicle is adequate

a the bearings on the boat trailer (buddy bearings) are greased

a the certificate numbers on the boat are valid

a two-way communication devices are operational

$\square$ boat lights are operational

a ventilation equipment is operational, if present

a a back-fire flame arrestor(s) is present (except for outboards)

boat battery(ies) is operational.

For longer outings to remote locations, other items such as food, water, and survival equipment should be added to the list.

\section{As boating operations begin, make sure that:}

- fuel tanks are full (know the fuel gas ratios for those that require mixing)

the boat has no leaks, has been bailed out, and has the boat plug in place

$\square$ the fuel lines and tank have no leaks

$\square$ the weather and water conditions are suitable

a all gear and supplies are properly stowed and secure

a the propeller is in good condition, with the lower unit free of weeds and debris

口 passengers are seated and briefed on emergency procedures, and personal floatation devices have been checked for fit

a the operator is alert and ready

․ the Float Plan/Boat Manifest Form has been filed with a responsible individual on shore

$\square$ communication devices are in good working order

口 bilge pump is working properly. 


\section{Pre-Trip Preparation Checklist}

from PNNL SBMS (http://sbms.pnl.gov/standard/1m/1m02e010.htm)

\section{Upon return:}

a refill fuel tanks

a review equipment inventory to verify that everything used on the boat has been returned and is accounted for

a clean the boat and equipment

remove the boat plug if the boat is stored outdoors

a stow equipment in the appropriate location

a check the tow vehicle and trailer for any equipment needs, repairs, or maintenance

recharge battery(ies) if needed

口 summarize any problems or anomalies and submit the summary to your line manager or responsible boat custodian; note these in a logbook

․ provide suggestions for operational improvements, if any, to boat custodian

- notify your supervisor, boat custodian, and/or staff members of any pertinent boat-related information (problems, changing access routes, maintenance needs, trailer or tow vehicle information, etc.). 


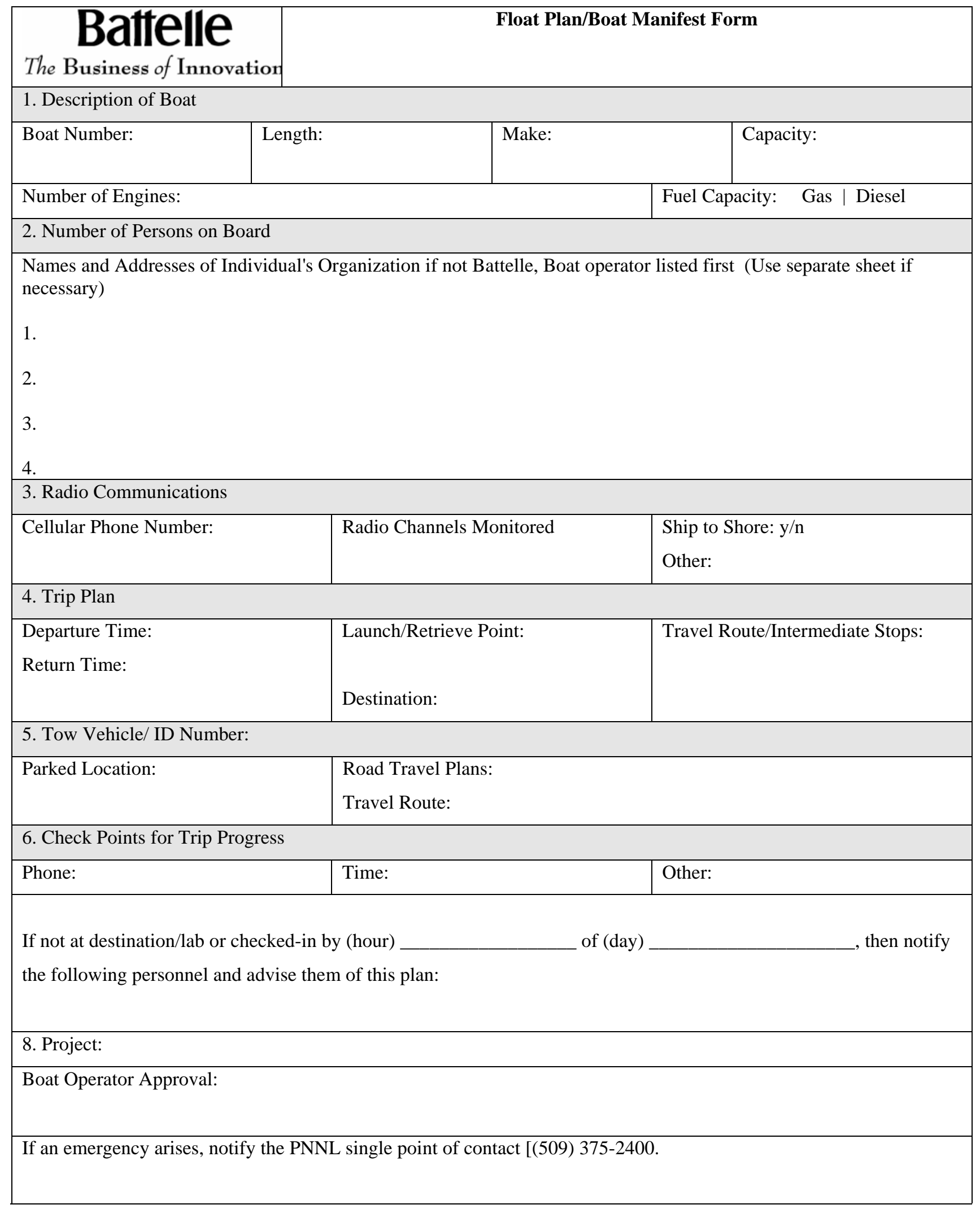




\subsection{ENVIRONMENTAL SAMPLING}

Environmental sampling is conducted at many locations on and off the site. Safety issues must be identified and addressed both prior to, and during all sampling activities.

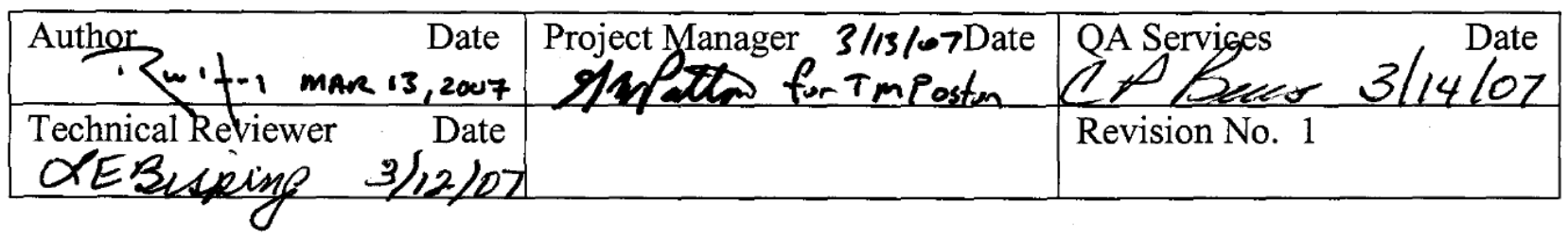


Section 9.2

Issued: 03-07

Supersedes: 03-02

PNL-MA-580

Page 3

\begin{tabular}{|c|c|c|c|c|c|c|}
\hline \multirow{2}{*}{\multicolumn{2}{|c|}{$\begin{array}{l}\text { JOB SAFETY } \\
\text { ANALYSIS }\end{array}$}} & \multicolumn{3}{|c|}{ Job Description: Environmental Sampling } & \multicolumn{2}{|c|}{ JSA Number: SESP-1 } \\
\hline & & \multicolumn{3}{|c|}{ Component: Env. Characterization \& Risk Assessment Group } & \multicolumn{2}{|c|}{ Building/Area: SIGMA 5/RCHN } \\
\hline & & \multicolumn{3}{|c|}{ Prepared By: R.W. (Bill) Hanf } & \multicolumn{2}{|c|}{ Date: Feb 13, 2007} \\
\hline WS\&H Approval: & Date: & EC\&RA Group Manager: & Date: & Reviewed by: & & \\
\hline \multicolumn{2}{|c|}{$\begin{array}{c}\text { SAFETY EQUIPMENT } \\
\text { REQUIRED } \\
\end{array}$} & \multicolumn{2}{|c|}{$\begin{array}{c}\text { TOOLS AND EQUIPMENT } \\
\text { REQUIRED } \\
\end{array}$} & \multicolumn{3}{|c|}{ JOB PREPARATION } \\
\hline \multirow{3}{*}{\multicolumn{2}{|c|}{$\begin{array}{ll}\text { - } & \text { Leather and or } \\
\text { surgical type vinyl or } \\
\text { latex gloves } \\
\text { - } & \text { Drinking water } \\
\text { - } & \text { Wire cutters } \\
\text { - } & \text { Two fire } \\
\text { - extinguishers } \\
\text { - } & \text { Shovel } \\
\text { - Cellular phone or } \\
\text { two-way radio }\end{array}$}} & \multicolumn{2}{|c|}{$\begin{array}{l}\text { See appropriate sections in } \\
\text { PNL-MA-580, Surface } \\
\text { Environmental Surveillance } \\
\text { Procedures Manual for sampling } \\
\text { information and requirements. }\end{array}$} & \multicolumn{3}{|c|}{$\begin{array}{l}\text { Inspect equipment and vehicle prior to leaving } \\
\text { staging area. Assure that all needed equipment is } \\
\text { on board and in good working order prior to } \\
\text { departure. Carry two fully charged, } 10 \text { lb. ABC- } \\
\text { rated dry chemical fire extinguishers, one shovel } \\
\text { and one pair of wire cutters in each vehicle at all } \\
\text { times. Assure that vehicle brakes, lights, tires, } \\
\text { wipers, etc., are in good working order. } \\
\text { Pre-plan the trip. } \\
\text { Check to confirm that the cellular phone or 2-way } \\
\text { radio is functional and the cellular phone battery is } \\
\text { charged. } \\
\text { Load vehicle so that movement of gear will be } \\
\text { minimized if an accident or sudden stop occurs. } \\
\text { Dress appropriately in cold weather. Keep clothes, } \\
\text { hands, and feet warm and dry, if possible. }\end{array}$} \\
\hline & & \multicolumn{2}{|c|}{ HAZARDOUS MATERIALS } & \multicolumn{3}{|c|}{ RELATED REQUIREMENTS } \\
\hline & & \multicolumn{2}{|c|}{$\begin{array}{ll}\text { - } & \text { Gasoline } \\
\text { - } & \text { Oil } \\
\text { - } & \text { Batteries }\end{array}$} & \multicolumn{3}{|c|}{ 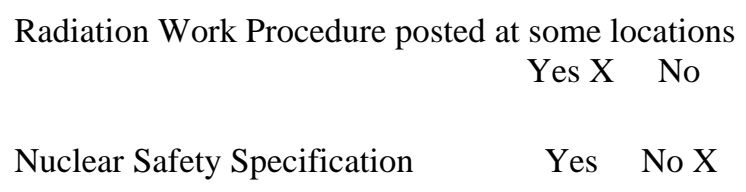 } \\
\hline & STEP & \multicolumn{2}{|c|}{ HAZARD } & \multicolumn{3}{|c|}{$\begin{array}{l}\text { HAZARD CONTROL AND PROTECTIVE EQUIPMENT } \\
\end{array}$} \\
\hline \multicolumn{2}{|c|}{ VEHICLE OPERATION } & \multicolumn{2}{|l|}{ Accidents } & \multicolumn{3}{|c|}{$\begin{array}{l}\text { Watch for wildlife on or near roads and highways. } \\
\text { Use extra caution when operating vehicles in } \\
\text { inclement weather or in unusual conditions and } \\
\text { follow all state, local and federal laws. } \\
\text { Wear seat belts. }\end{array}$} \\
\hline
\end{tabular}


Issued: 03-07

\begin{tabular}{|c|c|c|}
\hline JOB STEP & HAZARD & $\begin{array}{l}\text { HAZARD CONTROL AND PROTECTIVE EQUIPMENT } \\
\end{array}$ \\
\hline $\begin{array}{l}\text { VEHICLE OPERATIONS } \\
\text { (contd) }\end{array}$ & Fire & $\begin{array}{l}\text { Stay on existing trails if possible. } \\
\text { When operating off of paved surfaces, park so that } \\
\text { the vehicle exhaust system does not contact dry } \\
\text { vegetation. Inspect the bottom of the vehicle during } \\
\text { and after off-road operations for weeds caught on } \\
\text { the undercarriage and exhaust system. These weeds } \\
\text { could potentially catch on fire. }\end{array}$ \\
\hline OFF-ROAD TRAVEL & Rough terrain & $\begin{array}{l}\text { When possible, restrict rough terrain travel to } 4- \\
\text { wheel drive vehicles. Drive slowly and inspect the } \\
\text { ground carefully for possible hazards. } \\
\text { See Vehicles for Business Purposes at } \\
\text { http://sbms.pnl.gov/standard/0a/0a00t010.htm for } \\
\text { additional vehicle information. }\end{array}$ \\
\hline $\begin{array}{l}\text { SOIL AND VEGETATION } \\
\text { SAMPLES }\end{array}$ & $\begin{array}{l}\text { Snakes, ticks, trip hazards, sharp } \\
\text { cutting instruments }\end{array}$ & $\begin{array}{l}\text { Wear gloves, boots, and appropriate clothing. } \\
\text { Visually survey sampling area prior to work. Walk } \\
\text { carefully. Periodically check clothing for ticks, } \\
\text { especially when working in brushy areas near the } \\
\text { river in spring months. } \\
\text { Keep fingers away from blades when using grass } \\
\text { clippers and pruning shears to collect vegetation } \\
\text { samples. }\end{array}$ \\
\hline AIR SAMPLES & $\begin{array}{l}\text { Spiders, wasps, electrical shock, } \\
\text { sharp edges, back strain }\end{array}$ & $\begin{array}{l}\text { Spiders and stinging insects may seek shelter inside } \\
\text { air sampling hutches. Open doors cautiously and } \\
\text { look carefully before reaching in. } \\
\text { Be careful of sharp metal edges on the hutches. } \\
\text { Disconnect power before servicing or removing } \\
\text { electrical components. } \\
\text { When replacing air-sampling pumps, lift pumps } \\
\text { properly to avoid back strain. }\end{array}$ \\
\hline RIVER WATER SAMPLES & $\begin{array}{l}\text { Slippery floors, electrical shock } \\
\text { hazard, back strain }\end{array}$ & $\begin{array}{l}\text { Keep sampling area dry. Be aware of the potential } \\
\text { for electric shock when operating electrical } \\
\text { equipment near water. } \\
\text { Always disconnect power before servicing or } \\
\text { removing electrical components. } \\
\text { Lift heavy sample containers carefully, and using } \\
\text { proper technique, to avoid back strain. } \\
\text { During winter months, a buildup of snow and ice } \\
\text { may occur, adding to potential for slippery } \\
\text { conditions. }\end{array}$ \\
\hline
\end{tabular}




\begin{tabular}{|c|c|c|}
\hline JOB STEP & HAZARD & $\begin{array}{l}\text { HAZARD CONTROL AND PROTECTIVE EQUIPMENT } \\
\end{array}$ \\
\hline $\begin{array}{l}\text { MIDSTREAM RIVER } \\
\text { WATER AND SEDIMENT } \\
\text { SAMPLES }\end{array}$ & $\begin{array}{l}\text { Back and shoulder strain, falling } \\
\text { overboard, pinched fingers, } \\
\text { dropping equipment on feet }\end{array}$ & $\begin{array}{l}\text { Work cautiously on slippery boat decks. Don't lean } \\
\text { too far over the side of the boat. } \\
\text { If retrieving samples by hand (i.e. without using a } \\
\text { winch), watch out for shoulder or back strain. If } \\
\text { necessary, seek assistance for retrieval operations. } \\
\text { When using a power winch to obtain samples, avoid } \\
\text { getting fingers pinched in the winch mechanism or } \\
\text { cable, and watch out for frayed cable. Be careful } \\
\text { not to drop the sampler or other equipment on your } \\
\text { feet. } \\
\text { When using dredges, be careful to avoid getting } \\
\text { fingers pinched in the clamshell mechanism. } \\
\text { See JSA SESP-2, “Operation of Boats,” and "Boat } \\
\text { Operations” at } \\
\text { http://sbms.pnl.gov/standard/1m/1m00t010.htm for } \\
\text { more on boat safety. }\end{array}$ \\
\hline WILDLIFE SAMPLES & $\begin{array}{l}\text { Sharp cutting instruments, } \\
\text { abrasions or punctures from bones, } \\
\text { injury from firearms, parasites on } \\
\text { game animals, hantavirus }\end{array}$ & $\begin{array}{l}\text { Firearm safety is covered in JSA, SESP-4, "Using } \\
\text { Firearms.” } \\
\text { Work carefully. Wear leather, or surgical type } \\
\text { vinyl or latex gloves, and protective clothing, as } \\
\text { appropriate to minimize contact with the sample } \\
\text { organism's body fluids and discharges. } \\
\text { Be aware that some mice may be infected with the } \\
\text { hantavirus and that virus avoidance and cleanup } \\
\text { techniques should be practiced when handling and } \\
\text { processing these animals and their body parts. } \\
\text { Handle instruments with caution and use the proper } \\
\text { tool for each job. Keep fingers away from knife } \\
\text { blades and refrain from putting sharp instruments } \\
\text { into pockets. }\end{array}$ \\
\hline FISH SAMPLES & $\begin{array}{l}\text { Falling and/or drowning, puncture } \\
\text { wounds from fish hooks and sharp } \\
\text { fish spines or bones, sharp cutting } \\
\text { instruments }\end{array}$ & $\begin{array}{l}\text { See JSA SESP-2 "Operation of Boats," and "Boat } \\
\text { Operations" at } \\
\text { http://sbms.pnl.gov/standard/1m/1m00t010.htm for } \\
\text { more on boat safety. In addition, see JSA SESP-3 } \\
\text { "Operation of Electrofisher.” } \\
\text { Wear proper footwear when fishing or seining from } \\
\text { the shoreline. Insure firm footing when walking in } \\
\text { mud or on slippery rocks. If wading, proceed } \\
\text { slowly and carefully. Watch for holes, debris and } \\
\text { abrupt drop-offs while wading. }\end{array}$ \\
\hline
\end{tabular}


Section 9.2

Issued: 03-07

Supersedes: 03-02

PNL-MA-580

Page 6

\begin{tabular}{|c|c|c|}
\hline JOB STEP & HAZARD & $\begin{array}{l}\text { HAZARD CONTROL AND PROTECTIVE EQUIPMENT } \\
\end{array}$ \\
\hline SHORELINE SAMPLING & $\begin{array}{l}\text { Slippery or soft substrate, poor } \\
\text { visibility under water, ice along } \\
\text { shoreline, snakes, ticks, poisonous } \\
\text { vegetation }\end{array}$ & $\begin{array}{l}\text { Bait and cast hooks carefully. If necessary, use } \\
\text { gloves to remove spiny fish from hooks and nets. } \\
\text { Assure firm footing when walking in mud or on } \\
\text { slippery rocks. If wading, proceed slowly and } \\
\text { carefully; watch for holes, debris and sharp drop- } \\
\text { offs. In winter months, do not attempt to reach open } \\
\text { water by walking on shoreline ice. } \\
\text { Be aware that snakes and ticks inhabit rocky and/or } \\
\text { brushy areas near the water. Wear appropriate } \\
\text { footwear and clothing. Check thoroughly for ticks } \\
\text { following completion of the workday especially in } \\
\text { spring months. }\end{array}$ \\
\hline POND SAMPLING & Getting stuck in mud & $\begin{array}{l}\text { Wet or damp areas at West Lake may be extremely } \\
\text { soft. Standing in one spot for too long can result in } \\
\text { your feet sinking several inches into the mud, } \\
\text { making it difficult to extricate your feet. } \\
\text { Vehicles should not be parked or driven near the } \\
\text { water or in an area where water once was. The soil } \\
\text { surface in these locations may look solid but the } \\
\text { vehicle can still sink through the surface layer and } \\
\text { into the mud below. }\end{array}$ \\
\hline GENERAL & $\begin{array}{l}\text { Heat stress } \\
\text { Extreme cold }\end{array}$ & $\begin{array}{l}\text { Wear appropriate clothing for weather conditions. } \\
\text { On hot days, drink plenty of water to avoid } \\
\text { dehydration. } \\
\text { In extremely cold weather, assure that body } \\
\text { extremities are well protected. }\end{array}$ \\
\hline SAFETY NOTIFICATIONS & $\begin{array}{l}\text { Needing help or not being able to } \\
\text { request help if a problem arises, } \\
\text { communications fail, and/or } \\
\text { transportation is needed. }\end{array}$ & $\begin{array}{l}\text { Prior to leaving for the field, the person sampling } \\
\text { must notify his/her supervisor or manager of his/her } \\
\text { intentions, work locations, and estimated return } \\
\text { time. If the estimated return time will be exceeded, } \\
\text { the supervisor or manager must be notified. When } \\
\text { personnel return from the field, the supervisor or } \\
\text { manager must be notified. }\end{array}$ \\
\hline
\end{tabular}




\subsection{USING FIREARMS}

Firearms are used for collecting wildlife samples both on and off the site. No one will use a SESP firearm until they have taken the PNNL firearms safety training course and have had hands-on training (firing range) with the firearm being used. This training is an annual requirement. The firearms safety protocol will be read immediately prior to the use of any PNNL firearm. See Section 8.5 of this manual for procedures for the safe handling, transport, and storage of project firearms.

\begin{tabular}{|c|c|c|}
\hline 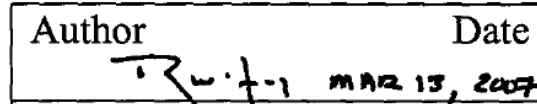 & 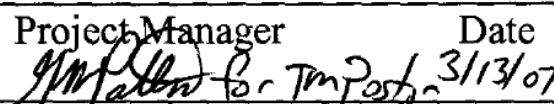 & QA Services \\
\hline $\begin{array}{l}\text { Technical Reviewer Date } \\
\text { PE Busping 3/13/07 }\end{array}$ & & Revision No. 1 \\
\hline
\end{tabular}


Section 9.3

Issued: 03-07

Supersedes: 02-03

PNL-MA-580

Page 3

\begin{tabular}{|c|c|c|c|c|c|c|c|}
\hline \multirow{2}{*}{\multicolumn{2}{|c|}{$\begin{array}{l}\text { JOB SAFETY } \\
\text { ANALYSIS }\end{array}$}} & \multicolumn{3}{|c|}{ Job Description: Using Firearms } & \multicolumn{3}{|c|}{ JSA Number: SESP-4 } \\
\hline & & \multicolumn{3}{|c|}{ Component: Env. Characterization \& Risk Assessment Group } & \multicolumn{3}{|c|}{ Building/Area: SIGMA 5/RCHN } \\
\hline \multirow{2}{*}{\multicolumn{2}{|c|}{ WS\&H Approval: }} & \multicolumn{3}{|c|}{ Prepared By: R.W. (Bill) Hanf } & \multicolumn{3}{|c|}{ Date: $02 / 06 / 2007$} \\
\hline & & \multicolumn{2}{|c|}{\begin{tabular}{l|l} 
EC\&RA Group Manager: & Date: \\
\end{tabular}} & Reviewed by: & Date: & & \\
\hline \multicolumn{2}{|c|}{$\begin{array}{c}\text { SAFETY EQUIPMENT } \\
\text { REQUIRED }\end{array}$} & \multicolumn{2}{|c|}{$\begin{array}{c}\text { TOOLS AND EQUIPMENT } \\
\text { REQUIRED } \\
\end{array}$} & \multicolumn{4}{|c|}{ JOB PREPARATION } \\
\hline \multirow{3}{*}{\multicolumn{2}{|c|}{$\begin{array}{ll}\text { - } & \text { Safety glasses. } \\
\text { - } & \text { Ear protection. } \\
\text { - } & \text { c-way radio or } \\
\text { - } & \text { First ailar telephone. } \\
\text { vehicle. in } \\
\text { - Hunter's-orange } \\
\text { clothing. } \\
\text { - Phone list of } \\
\text { emergency or } \\
\text { informational } \\
\text { contacts. }\end{array}$}} & \multicolumn{2}{|c|}{$\begin{array}{ll}\text { - } & \text { Shotgun or rifle. } \\
\text { - } & \text { Correct ammunition. } \\
\text { - } & \text { Gun case. } \\
\text { - } & \text { Firearm cleaning } \\
& \text { supplies. }\end{array}$} & \multicolumn{4}{|c|}{$\begin{array}{l}\text { Personnel using firearms for research activities } \\
\text { must have completed the PNNL firearms safety- } \\
\text { training course within the past year. Personnel } \\
\text { using firearms must also read the protocol for safe } \\
\text { handling, transport, and storage of firearms } \\
\text { (attached) prior to each use, the Surface } \\
\text { Environmental Surveillance Project procedures for } \\
\text { using firearms (PNL-MA-580, Section 8.5), and } \\
\text { review the SBMS web page "Firearms Safety" at } \\
\text { http://sbms.pnl.gov/standard/20/2000t010.htm. } \\
\text { Personnel must be familiar with, and follow, } \\
\text { Washington State hunters-safety rules. Refer to the } \\
\text { safety and accident information in the hunters } \\
\text { safety pamphlet located in the gun storage cabinet. } \\
\text { Prior to leaving for the field, notify the PNNL } \\
\text { Operations Center about sampling intentions and } \\
\text { locations: } \\
\text { Phone: } 375-2154 \\
\text { E-mail: } \wedge \text { PNNL Operations Center }\end{array}$} \\
\hline & & \multicolumn{2}{|c|}{ THAZARDOUS MATERIALS } & \multicolumn{4}{|c|}{ RELATED REQUIREMENTS } \\
\hline & & \multicolumn{2}{|c|}{$\begin{array}{ll}\text { - } & \text { Firearms } \\
\text { - } & \text { Ammunition } \\
\text { - } & \text { Gun-cleaning solvent }\end{array}$} & \multicolumn{4}{|c|}{$\begin{array}{lcc}\text { Radiation Work Procedure } & \text { Yes } & \text { No X } \\
\text { Nuclear Safety Specification } & \text { Yes } & \text { No X }\end{array}$} \\
\hline \multicolumn{2}{|c|}{ JOB STEP } & \multicolumn{2}{|c|}{ HAZARDS } & \multicolumn{4}{|c|}{ " HAZARD CONTROL AND PROTECTIVE EQUIPMENT } \\
\hline \multicolumn{2}{|c|}{$\begin{array}{l}\text { REMOVING FIREARMS } \\
\text { AND AMMUNITION } \\
\text { FROM STORAGE; } \\
\text { TRANSPORTING } \\
\text { FIREARMS; LOADING } \\
\text { FIREARMS }\end{array}$} & \multicolumn{2}{|c|}{$\begin{array}{l}\text { Loaded firearms, accidental } \\
\text { discharge, leaving gun-storage } \\
\text { cabinet unlocked }\end{array}$} & \multicolumn{4}{|c|}{$\begin{array}{l}\text { Contact the firearms custodian to retrieve the } \\
\text { firearm and ammunition from locked storage. } \\
\text { Read and follow the requirements in the safety } \\
\text { protocol for handling, transporting, and storing } \\
\text { firearms. } \\
\text { Visually verify that the firearm is unloaded. } \\
\text { Place the firearm in its case for transport. } \\
\text { Leave the firearm unloaded with the action open } \\
\text { until it is removed from the vehicle at the collection } \\
\text { site. }\end{array}$} \\
\hline
\end{tabular}


Section 9.3

Issued: 03-07

Supersedes: 02-03

PNL-MA-580

Page 4

\begin{tabular}{|c|c|c|}
\hline JOB STEP & HAZARDS & HAZARD CONTROL AND PROTECTIVE EQUIPMENT \\
\hline $\begin{array}{l}\text { REMOVING FIREARMS } \\
\text { AND AMMUNITION } \\
\text { FROM STORAGE; } \\
\text { TRANSPORTING } \\
\text { FIREARMS; LOADING } \\
\text { FIREARMS } \\
\text { (contd) }\end{array}$ & & $\begin{array}{l}\text { After the firearm is loaded at the collection site, } \\
\text { keep the firearm safety engaged until ready to } \\
\text { shoot. Re-engage the firearm safety after shooting. } \\
\text { Verify that the firearm is unloaded with the action } \\
\text { open before putting the firearm back into its case, } \\
\text { and then into the vehicle. Loaded firearms are not } \\
\text { allowed in vehicles. }\end{array}$ \\
\hline $\begin{array}{l}\text { WALKING WITH } \\
\text { FIREARMS }\end{array}$ & Falls and accidental discharge & $\begin{array}{l}\text { Follow the guidelines outlined in the Washington } \\
\text { State hunter-safety pamphlet. } \\
\text { While walking with a loaded firearm, the user will } \\
\text { at all times keep the firearm safety on and the } \\
\text { firearm pointed in a safe direction. }\end{array}$ \\
\hline SHOOTING & $\begin{array}{l}\text { Hitting personnel or property, } \\
\text { damage to eyes or ears }\end{array}$ & $\begin{array}{l}\text { Wear hunter's-orange clothing. } \\
\text { Assure that the collection area is clear of other } \\
\text { personnel, vehicles, or structures. } \\
\text { Wear eye and ear protection. } \\
\text { Be sure that the background is clear before } \\
\text { shooting. } \\
\text { Do not shoot from a vehicle. } \\
\text { Follow additional safety rules outlined in the } \\
\text { Washington State hunters-safety pamphlet. } \\
\text { Limit shooting to the minimum required for the } \\
\text { task. }\end{array}$ \\
\hline
\end{tabular}


Prepared for the Environmental Characterization \& Risk Assessment Group and the Ecology Group.

\section{PROTOCOL FOR THE SAFE HANDLING, TRANSPORT, AND STORAGE OF FIREARMS}

\section{Handling of Firearms}

The following protocol will be followed by anyone using a firearm. Firearms included in this protocol include tranquilizer guns, rifles, shotguns, and net guns.

1. On removing any firearm from the storage cabinet, check the chamber, magazine, and barrel for ammunition or other obstructions. If none are found, the firearm will be considered safe for transport to the area of intended use.

2. Staff on medication which could impair motor skills or judgment, are not to use firearms unless cleared by a physician.

3. Battelle Security will be notified prior to the transport and use of a firearm in the field on the Hanford Project.

4. Upon approach and arrival to the area of use, be watchful for signs of other personnel, vehicles or structures whose safety may be compromised because of your use of firearms. Assure the hunting area is clear and be constantly alert for changing conditions. Prior to loading any firearm, the chamber and barrel shall again be checked to assure that the firearm is free from obstructions. Firearms shall not be loaded while inside a vehicle. Loading will be done outside the vehicle and with the firearm pointed in a safe direction, away from all people, equipment and structures.

5. Only proper size ammunition will be used in a firearm.

6. While carrying a loaded firearm, the user will at all times, keep the safety on and the firearm pointed in a safe direction.

7. Immediately after use, the firearm will be unloaded. It will not be placed in a case or in a transporting vehicle until it has been unloaded. Transport the firearm with the action open. When returning a firearm to its storage location, again check that it is unloaded and the action left open.

8. In the case of a jammed gun, (one containing live ammunition or a dud), the user will notify the firearm custodian of the problem. The notified custodian will prescribe the proper technique for handling the firearm until the problem can be resolved.

9. At no time will a loaded firearm be allowed in a building unless prior approval from the line manager and the firearm subject matter expert has been received in advance (normally for dealing with issues discussed in item \# 8). 
10. No one will use a firearm until they have taken the PNNL Firearms Safety Training Course, have been trained in the use of the specific firearm to be used and have acknowledged by signature that they have read and understood this protocol.

\section{Transport of Firearms}

1. Firearms transported in vehicles will be unloaded and the action left open.

2. In the case of transport in a boat, the user will keep the firearm unloaded until ready to use it.

\section{Storage of Firearms and Ammunition}

1. All firearms will be stored in a locked cabinet. Firearms will be signed-out/signed-in on the Firearms Sign-out/Sign-in Sheet located in the gun cabinet.

2. Firearms will be rechecked to make sure they are unloaded and the action left open before placing in the gun cabinet.

3. Do not leave the firearm in a gun case while in the gun cabinet.

4. If the firearm has been fired in the field, the user will clean it on return to storage.

5. Any malfunctioning firearm shall be tagged and reported to the firearm custodian. It will be the custodian's responsibility to see that it is repaired.

6. Ammunition which misfired or is damaged will be given to the firearm custodian for proper disposal.

Approvals:

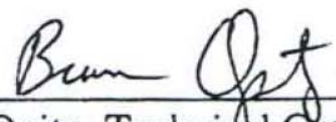

B. E. Opitz, Technifal Group Manager

Environmental Characterization and Risk Assessment

(N2und

C. A. Brandt, Technical Group Leader

Ecology Group

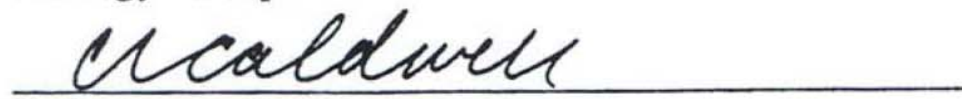

C. L. Caldwell, Manager

Worker Safety and Health

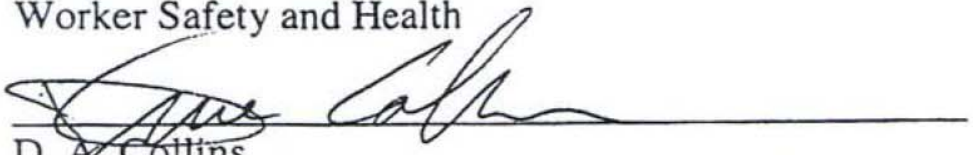

D. A. Collins

Industrial Hygiene and Occupational Safety Ops

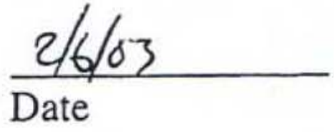

$2 \cdot 6 \cdot 03$

Date

$4-15-03$

Date

$2-10-03$

Date 


\subsection{OPERATION OF ELECTROFISHER}

A boat-mounted electrofisher is used periodically to collect fish samples from the Columbia River (see Section 7.1 of this manual for electrofisher operating procedures). All personnel working with this equipment must have the appropriate electrical safety training prior to conducting collection activities.

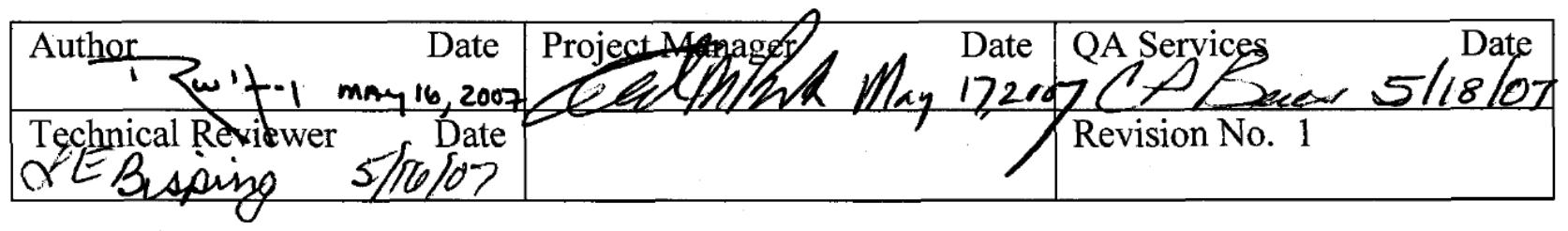


Section 9.4

Issued: 05-07

Supersedes: 02-03

PNL-MA-580

Page 3

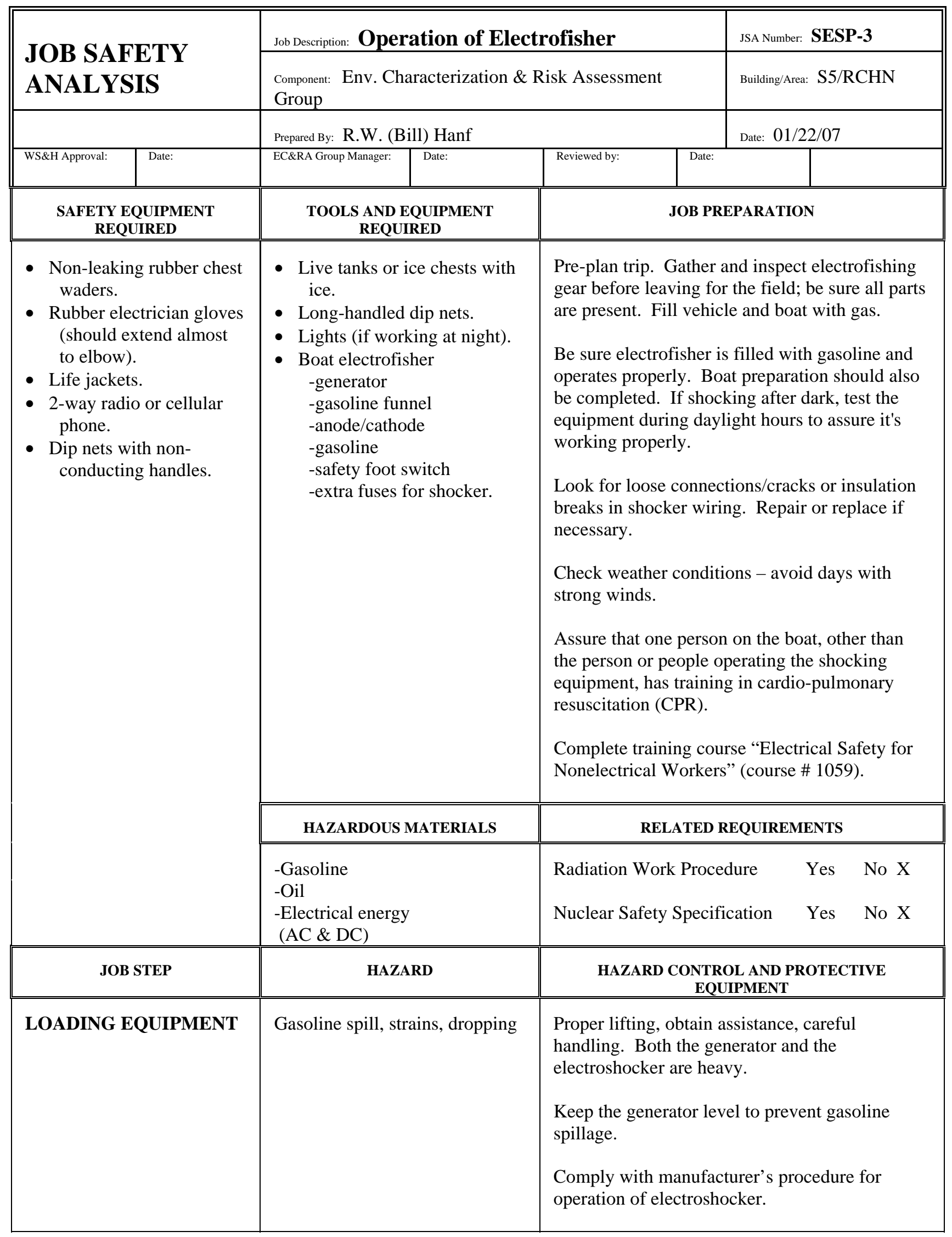


Section 9.4

Issued: 05-07

Supersedes: 02-03

PNL-MA-580

Page 4

\begin{tabular}{|c|c|c|}
\hline JOB STEP & HAZARD & $\begin{array}{l}\text { HAZARD CONTROL AND PROTECTIVE } \\
\text { EQUIPMENT }\end{array}$ \\
\hline FISH SHOCKING & $\begin{array}{l}\text { Strains, falling, drowning, } \\
\text { electrical shock, burns, head } \\
\text { bumps (from net handles), all } \\
\text { additional boat operation } \\
\text { hazards }\end{array}$ & $\begin{array}{l}\text { Comply with JSA SESP-2, “Operation of } \\
\text { Boats,” PNNL SBMS Boat Operations } \\
\text { requirements at http://sbms.pnl.gov/ } \\
\text { standard/1m/1m00t010.htm, and with the rules } \\
\text { and regulations in the state boaters guide. } \\
\text { Read and follow the electrofishing procedures in } \\
\text { the Surface Environmental Procedures Manual } \\
\text { (Section 7.1, PNL-MA-580). } \\
\text { Be careful of tripping and falling over wires and } \\
\text { equipment in the boat. } \\
\text { Wear rubber electrician gloves, rubber chest } \\
\text { waders, and life jackets when shocking. Keep } \\
\text { inside of boots and gloves dry. } \\
\text { Keep legs away from hot generator exhaust } \\
\text { manifold. } \\
\text { Avoid hitting other personnel with net handles. } \\
\text { A minimum of two people are required. One } \\
\text { will drive the boat. The other will operate the } \\
\text { foot safety switch and collect fish. } \\
\text { Fish collectors should stand in the boat (not on } \\
\text { the bow). Fish collector should brace for } \\
\text { unexpected changes in boat speed and direction. } \\
\text { Make sure there are no other people or animals } \\
\text { within } 100 \text { meters of the shocking area before } \\
\text { energizing the equipment. }\end{array}$ \\
\hline $\begin{array}{l}\text { REFUELING THE } \\
\text { GENERATOR }\end{array}$ & Burns, explosion, spills & $\begin{array}{l}\text { Stop engine and allow time to cool down. Do } \\
\text { not overfill the gas tank. } \\
\text { DO NOT SMOKE!! } \\
\text { Clean-up all spills before starting generator. }\end{array}$ \\
\hline
\end{tabular}


PNNL-16744

PNL-MA-580, Rev. 5

\section{Distribution}

No. of

Copies

ONSITE (11)

CP Beus

LE Bisping

BG Fritz

RW Hanf
No. of

Copies

GW Patton

K6-75

TM Poston

K6-75

A Stegen

K3-66

$\mathrm{K} 6-75$

DOE Public Reading Room (2)

H2-53

Hanford Technical Library (2)
P8-55 